María Gladys Agudelo Gil (Pereira, Risaralda, Colombia, 1965).

Doctora en Ciencias de la Educación (Rudecolombia), Magíster en Lingüística (Universidad de Antioquia) y Licenciada en Español y Comunicación audiovisual (Universidad Tecnológica de Pereira). Profesora titular de la Universidad Tecnológica de Pereira, adscrita al Departamento de Psicopedagogía de la Facultad de Ciencias de la Educación.

Coautora de los libros La lectura y la escritura en la Universidad (2010), Pensamiento y Palabra (2014), Batería para el diagnóstico y caracterización lingüistica de las afasias en el contexto risaraldense (2020).

Ha publicado artículos en revistas especializadas nacionales e internacionales.

Coordina el grupo de investigación GELE (Grupo de estudio en Lectura y Escritura).

magu@utp.edu.co

Leandro Arbey Giraldo Henao (Pereira, Risaralda, Colombia, 1978).

Doctor en Ciencias de la Educación (Rudecolombia). Magister en Lingüística y Licenciado en Español y Comunicación Audiovisual (Universidad Tecnológica de Pereira). Profesor titular adscrito a la Escuela de Español y comunicación audiovisual de la Facultad de Ciencias de la Educación de la Universidad Tecnológica de Pereira, Autor de los libros: Forma y sentido de la ciencia del lenguaje. Fundamentos teóricos y prácticos del discurso lingüístico, pedagógico y juvenil (2016), Representaciones discursivas del habla juvenil en la Educación Media (2017), Entropías necesarias. Provocaciones del lenguaje, la Filosofía y la literatura para una educación crítica (2018), Enunciaciones. Perspectiva interdisciplinar, transdisciplinar $y$ pedagógica del lenguaje, la comunicación y el cine (2019).

Ha publicado artículos en revistas especializadas nacionales e internacionales.

Coordina el grupo de investigación A.C.D.M (Análisis Crítico del Discurso Multimodal: Estudios y aplicaciones transversales en ámbitos socio-académicos) y el Semillero de investigación Discursos Multimodales.

lagh@utp.edu.co

Alejandro Alberto Mesa Mejía (Apía, Risaralda, Colombia, 1967).

Especialista en enseñanza de la literatura (Universidad del Quindío) y Licenciado en Español y Comunicación audiovisual (Universidad Tecnológica de Pereira).

Coautor del libro Pensamiento y Palabra (2014).

Ha publicado artículos en revistas nacionales.

Integrante del grupo de investigación GELE (Grupo de estudio en Lectura y Escritura).
Gloria Inés Correa Aristizábal (Anserma, Caldas, Colombia, 1970).

Estudiante del Doctorado en Ciencias de la Educación (Universidad Cuauhtemoc, México), Magíster en Pedagogía y Desarrollo Humano (Universidad Católica de Pereira), Especialista en Desarrollo del Potencial Humano (Universidad Antonio Nariño de Manizales), Especialista en Edumática (Universidad Católica de Pereira) y Licenciada en Pedagogía Reeducativa (Universidad Católica Luis Amigó de Manizales)

Profesora Auxiliar de la Universidad Tecnológica de Pereira, adscrita a la Escuela de Español y Comunicación Audiovisual de la Facultad de Ciencias de la Educación.

Ha publicado artículos en revistas especializadas nacionales e internacionales.

Integrante del grupo de investigación GELE (Grupo de estudio en Lectura y Escritura).

gica@utp.edu.co

Sebastián Martínez Botero (Pereira, Risaralda, Colombia 1980).

Doctor en Historia (Universidad Pablo de Olavide, España), Magíster en Historia del Mundo Hispánico (Universitat Jaume I, España) e Historiador profesional (Universidad Industrial de Santander, Colombia). Profesor auxiliar adscrito a la Escuela de Ciencias Sociales de la Facultad de Educación de la Universidad Tecnológica de Pereira. Es director de la revista Ciencia Nueva. Revista en Historia y Política; y es coordinador del Archivo Histórico Municipal de Pereira.

Sus más recientes publicaciones son: Representaciones geográficas de un territorio de frontera: el centro occidente colombiano, 1850-1905, Historia y Sociedad, No. 39 (2020): Repensando la historia urbana. Reflexiones históricas en torno a la ciudad colombiana. (UTP-ICESI, 2020) compilador.

sebastian.martinez@utp.edu.co

La Editorial de la Universidad Tecnológica de Pereira tiene como política la divulgación del saber científico, técnico y humanístico para fomentar la cultura escrita a través de libros y revistas científicas especializadas.

Las colecciones de este proyecto son: Trabajos de Investigación, Ensayos, Textos Académicos y Tesis Laureadas.

Este libro pertenece a la Colección Trabajos de Investigación. 


\title{
Competencias comunicativas en la educación superior: Fundamentos, procesos y productos
}

\author{
María Gladys Agudelo Gil \\ Leandro Arbey Giraldo Henao \\ Alejandro Alberto Mesa Mejía \\ Gloria Inés Correa Aristizábal \\ Sebastián Martínez Botero
}

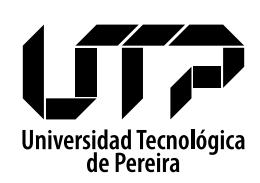

Colección Trabajos de Investigación

Facultad Ciencias de la Educación 2020 
Competencias comunicativas en la educación superior :

Fundamentos, procesos y productos / María Gladys Agudelo

Gil y otros. - Pereira : Editorial Universidad Tecnológica de

Pereira, 2020

211 páginas. -- (Colección Trabajos de investigación).

ISBN: 978-958-722-512-9

1. Competencias comunicativas 2. Educación - Lingüística 3. Comunicación oral - Enseñanza 4. Arte de escuchar - Enseñanza

Argumentación 5. Análisis del discurso 6. Lectura - Educación

superior 7. Escritura - Enseñanza - Educación superior 8.

Comunicación oral - Enseñanza superior.

CDD. 372.6

\section{Autores}

(C) María Gladys Agudelo Gil

(C) Leandro Arbey Giraldo Henao

(C) Alejandro Alberto Mesa Mejía

(c) Gloria Inés Correa Aristizábal

(c) Sebastián Martínez Botero

Universidad Tecnológica de Pereira

Pereira, Colombia

\section{Proyecto de Investigación}

«Impacto de la Estrategia de acompañamiento a los estudiantes de licenciatura de la Facultad de Ciencias de la Educación, de la Universidad Tecnológica de Pereira, en materia de competencias comunicativas»

Código: 4-18-6

\section{Universidad Tecnológica de Pereira}

Vicerrectoría de Investigaciones, Innovación y Extensión

Editorial Universidad Tecnológica de Pereira

Pereira, Colombia

Coordinador editorial:

Luis Miguel Vargas Valencia

luismvargas@utp.edu.co

Teléfono 3137381

Edificio 9, Biblioteca Central "Jorge Roa Martínez"

Cra. 27 No. 10-02 Los Álamos, Pereira, Colombia

www.utp.edu.co

Montaje y producción:

David Restrepo Suarez.

Universidad Tecnológica de Pereira 



\section{CONTENIDO}

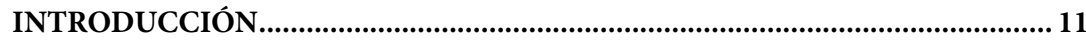

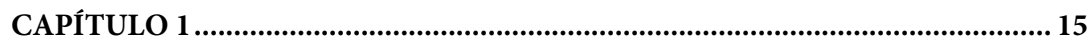

Acompañamiento a estudiantes de licenciatura, en sus competencias

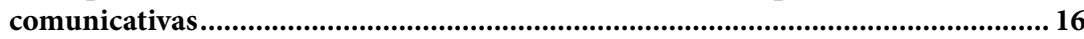

1.1 Diagnóstico, retroalimentación y aplicación, claves para el desarrollo de competencias comunicativas ....................................................................................... 18

1.2 Fundamentos metodológicos.............................................................................. 23

1.2.1 La interactividad en el discurso educacional: mecanismo de intervención

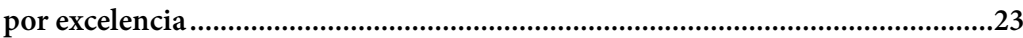

1.2.2 Tras resultados de pre-test y pos-test: técnicas cuantitativas y cualitativas 25

1.2.3 El plan de análisis y establecimiento de resultados.......................................26

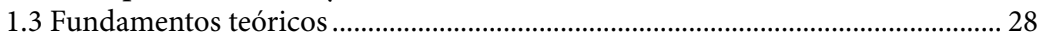

1.3.1 Antecedentes, problemas y precisiones sobre la tipificación del género ...29

1.3.2 El género discursivo: apuestas teóricas para su comprensión......................38

1.3.3 Tipologías textuales: formas de organizar el pensamiento y el discurso.51

1.3.4. Tipos de escrito y/o productos textuales ......................................................52

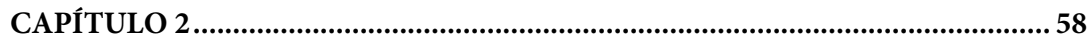

Procesos y productos de lectura..................................................................................... 59

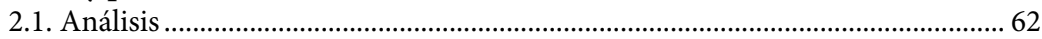

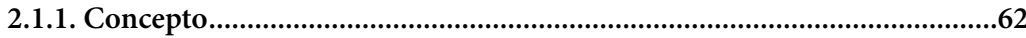

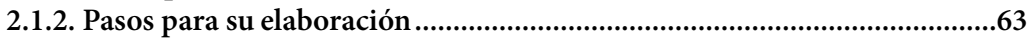

2.1.3 Presentación (estructura formal) ................................................................67

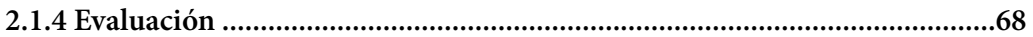

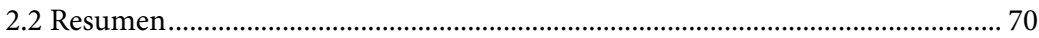

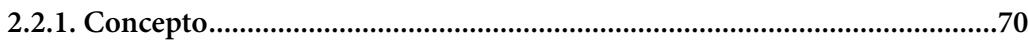

2.2.2 Procedimiento para su elaboración .......................................................70

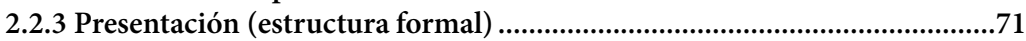

2.2.4 Evaluación ......................................................................................................73

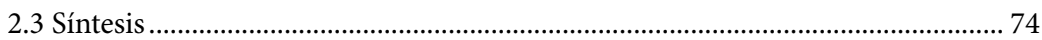

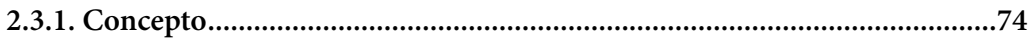

3.3.2 Procedimiento para su elaboración ................................................................74

2.3.3 Presentación (estructura formal) ………….................................................75

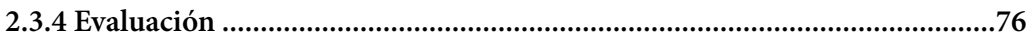

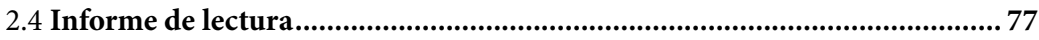

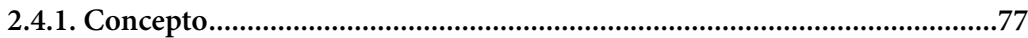

2.4.2 Procedimiento para su elaboración ...............................................................78

2.4.3 Presentación (estructura formal) .................................................................81

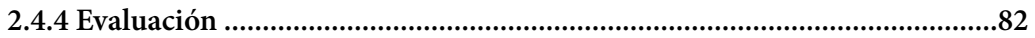

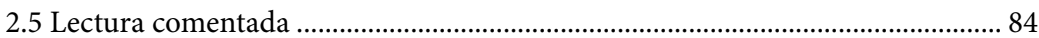

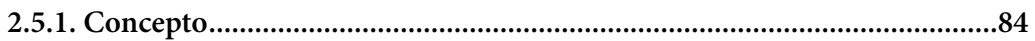

2.5.2 Procedimiento para su elaboración .........................................................85

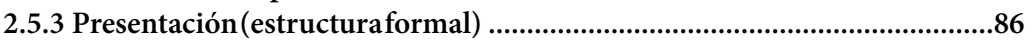

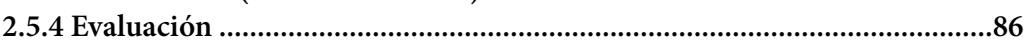

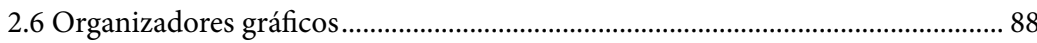




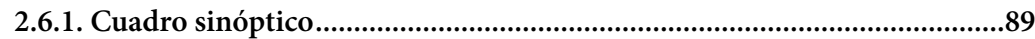

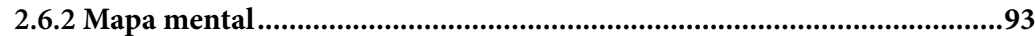

2.6.3 Mapa conceptual .......................................................................................97

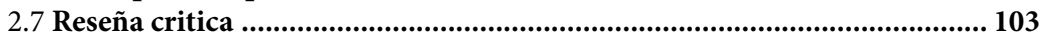

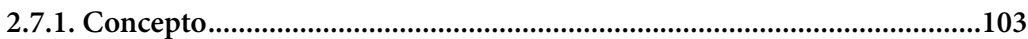

2.7.2 Procedimiento para su elaboración ...........................................................103

2.7.3 Presentación (estructura formal) .............................................................104

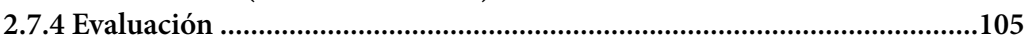

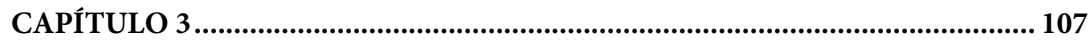

Procesos y productos de escritura............................................................................... 108

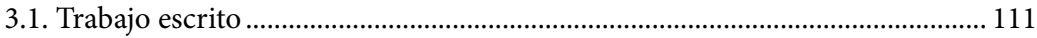

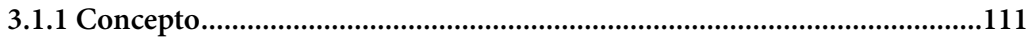

3.1.2 Procedimiento para su elaboración ......................................................113

3.1.3 Presentación (estructura formal) ................................................................114

3.1.4. Aplicación de normas en los trabajos escritos .........................................119

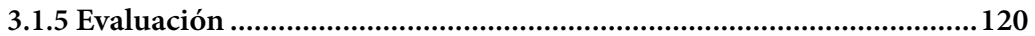

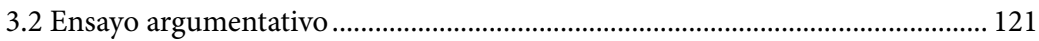

3.2.1. Concepto.......................................................................................................121

3.2.2 Procedimiento para su elaboración ...........................................................122

3.2.3 Algunas características del ensayo argumentativo.....................................125

3.2.4. Presentación (estructura formal) …………........................................129

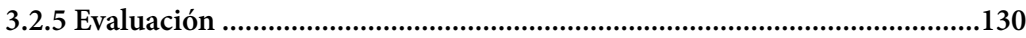

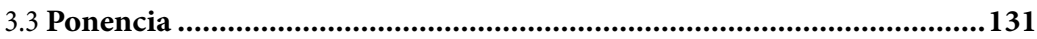

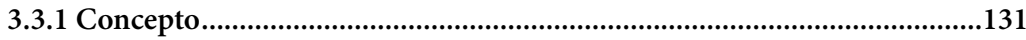

3.3.2 Procedimiento para su elaboración .............................................................133

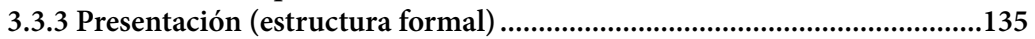

3.3.4 Evaluación ...................................................................................................135

3.4 Importancia de la ortografía castellana en los productos de escritura...... 140

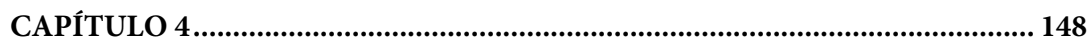

Procesos y productos de la oralidad ...................................................................... 149

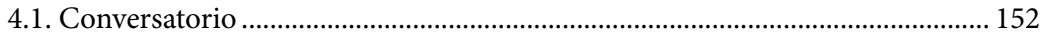

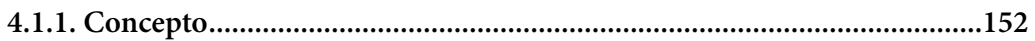

4.1.2 Procedimiento para su realización.............................................................153

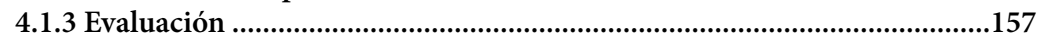

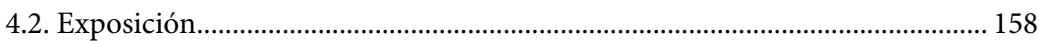

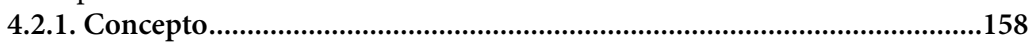

4.2.2 Procedimiento para su realización.............................................................161

4.2.3 Presentación (momentos de realización) ................................................167

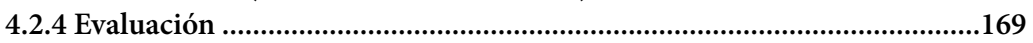

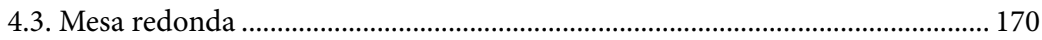

4.3.1. Concepto.......................................................................................170

4.3.2. Procedimiento para su realización..............................................................172

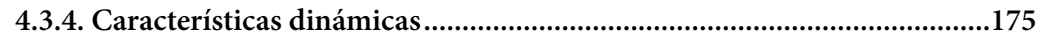

4.3.5. Recomendaciones al grupo organizador del encuentro ............................175

4.3.6. Sugerencias dirigidas a los integrantes de la mesa redonda .....................176

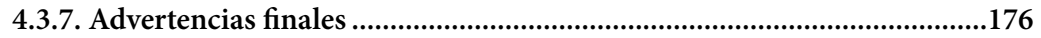


4.3.8. Presentación (momentos de realización) …........................................177

4.3.9 Evaluación ................................................................................................177

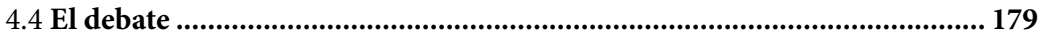

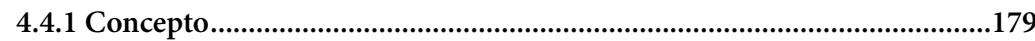

4.4.2 Procedimiento para su realización ..........................................................181

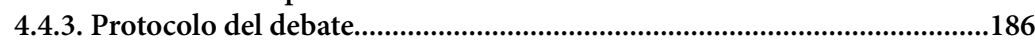

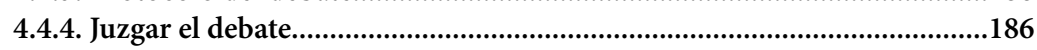

4.4.5. Comentarios personales y grupales .........................................................186

4.4.6. Asignar la calificación.............................................................................187

4.4.7. Pasos a seguir para la realización del debate ...........................................188

4.4.8 Estructura (momentos de realización) ........................................................192

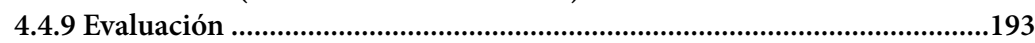

Consideraciones finales............................................................................................ 195

Referencias bibliográficas ......................................................................................... 199 


\section{FIGURAS}

Figura NRo. 1. Estrategia de acompañamiento a estudiantes de licenciatura: líneas de

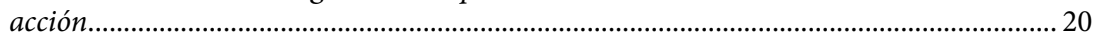

FIgURA NRo. 2. Estrategia de acompañamiento a estudiantes de licenciatura: propósitos

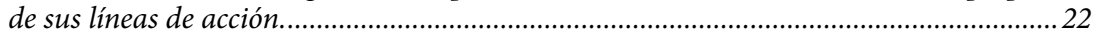

FIGURA NRO. 3. Sistema lingüístico: tesoro interior para la generación discursiva......36

FIGURA NRO. 4. La construcción del proceso argumentativo en el discurso.................43

Figura NRo. 5. Tipos de géneros y tipos de textos......................................................4. 44

FIGURA NRo. 6. Orígenes de la polifonía y el dialogismo...........................................45

FIGURA NRO. 7. Estructura del cuento tradicional (creación clásica)........................54

FIGURA NRO. 8. Estructura del cuento tradicional (creación contemporánea)...........54

FIGURA NRO. 9. Producción e interpretación textual: relación autor-lector. ..............59

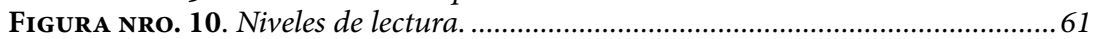

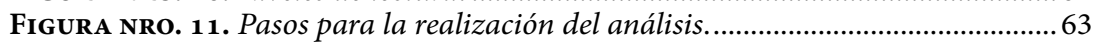

FIGURA NRO. 12. Macrorreglas para la realización del resumen. ............................ 72

Figura NRo. 13. Partes del informe de lectura....................................................79

FIGURA NRO. 14. El cuadro sinóptico, una forma de representación. .........................91

FIGURA NRO. 15. Ejemplo de mapa mental........................................................95

FIGURA NRO. 16. Mapa conceptual: representación de un concepto..........................97

FIGURA NRO. 17. Mapa conceptual: enlace y palabra de enlace................................ 98

FIGURA NRO. 18. Mapa conceptual: representación de una proposición....................98

FIGURA NRO. 19. Mapa conceptual: representación de una relación cruzada............99

FIGURA NRO. 20. Ejemplo de un mapa conceptual. .................................................. 100

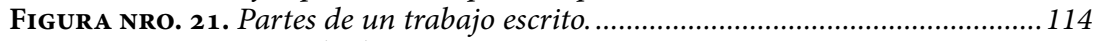

FIGURA NRO. 22. Ejemplo de secuencia argumentativa............................................ 125

FIGURA NRO. 23. Etapas de realización de la exposición............................................. 161 


\section{TABLAS}

TABLA NRO. 1. Plan de énfasis metodológico sugerido a docentes para aplicar en el aula.

TABLA NRo. 2. Asignaturas encargadas de la aplicación de los énfasis metodológicos.

TABLA NRo. 3. Géneros discursivos pensados desde las necesidades humanas. ....50

TABLA NRo. 4. Características del discurso, del texto y del escrito.........................55

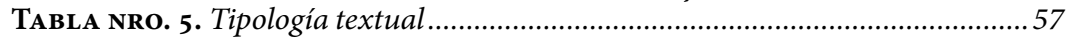

TABLA NRO. 6. Indicadores de cada uno de los niveles de lectura.........................62

TABLA NRO. 7. Rejilla para la valoración del análisis...........................................69

TABLA NRO. 8. Equivalencias para la valoración del análisis. ....................................70

TABLA NRo. 9. Rejilla para la valoración del resumen........................................ 73

TABLA NRO. 10. Equivalencias para la valoración del resumen.....................................74

TABLA NRO. 11. Rejilla para la valoración de la síntesis. ..................................... 76

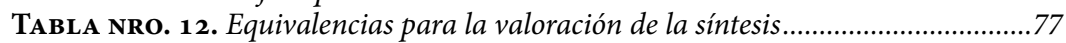

TABLA NRo. 13. Presentación del informe de lectura: portada............................. 81

TABLA NRo. 14. Presentación del informe de lectura: disposición de sus partes. .. 82

TABLA NRO. 15. Rejilla para la valoración del informe de lectura.........................8 83

TABLA NRO. 16. Equivalencias para la valoración del informe de lectura...................84

TABLA NRo. 17. Rejilla para la valoración de la lectura comentada. ....................87

TABLA NRO. 18. Equivalencias para la valoración de la lectura comentada................88

TABLA NRO. 19. El cuadro sinóptico, otra forma de representación. ............................91

TABLA NRO. 20. Rejilla para la valoración del cuadro sinóptico. ............................ 92

TABLA NRO. 21. Equivalencias para la valoración del cuadro sinóptico........................93

TABLA NRO. 22. Rejilla para la valoración del mapa mental. ................................ 96

TABLA NRO. 23. Equivalencias para la valoración del mapa mental........................96

TABLA NRo. 24. Procedimiento para la elaboración del mapa conceptual. ............101

TABLA NRO. 25. Rejilla para la valoración del mapa conceptual...........................102

TABLA NRO. 26. Equivalencias para la valoración del mapa conceptual. ...................102

TABLA NRO. 27. Rejilla para la valoración de la reseña crítica............................... 105

TABLA NRO. 28. Equivalencias para la valoración de la reseña crítica. ......................106

TABLA NRO. 29. Ejemplo de portada del trabajo escrito.............................................115

TABLA NRO. 30. Ejemplo de contenido o índice del trabajo escrito. ........................116

TABLA NRO. 31. Rejilla para la valoración del trabajo escrito.................................120

TABLA NRO. 32. Equivalencias para la valoración del trabajo escrito..........................121

TABLA NRo. 33. Rejilla para la valoración del ensayo argumentativo...................................130

TABLA NRO. 34. Equivalencias para la valoración del ensayo argumentativo. ............131

TABLA NRO. 35. Las competencias comunicativas en la ponencia...............................136

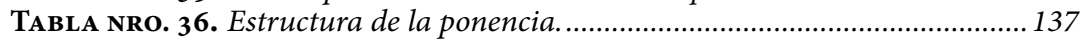

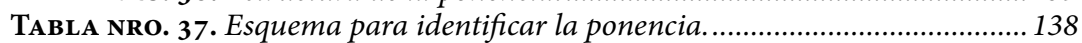

TABLA NRo. 38. Rejilla para la valoración de la ponencia.....................................138

TABLA NRO. 39. Equivalencias para la valoración de la ponencia. ............................140

TABLA NRO. 40. Rejilla para la valoración del conversatorio................................. 157

TABLA NRO. 41. Equivalencias para la valoración del conversatorio. ..........................158

TABLA NRo. 42. Ayudas audiovisuales: recomendaciones para su diseño y uso... 162

TABLA NRO. 43. Rejilla para la valoración de la exposición..................................169

TABLA NRO. 44. Equivalencias para la valoración de la exposición............................170

TABLA NRO. 45. Rejilla para la valoración de la mesa redonda............................. 178 
TABLA NRO. 46. Equivalencias para la valoración de la mesa redonda......................179

TABLA NRO. 47. Rejilla para la valoración del debate...........................................193

TABLA NRO. 48. Equivalencias para la valoración del debate......................................194 



\section{INTRODUCCIÓN}

Las competencias comunicativas, materializadas en la lectura, la escritura, la escucha y la oralidad, han sido preocupación dela academiadurantevariasdécadas, especialmente en la educación superior, donde se ha presentado de forma extensiva.

Por este motivo, un grupo de profesores de los programas de pregrado de la Facultad de Ciencias de la Educación de la Universidad Tecnológica de Pereira (UTP) quienes por su formación como lingüistas, pedagogos, literatos e historiadores aportan a la construcción interdisciplinaria, hicieron una revisión a los antecedentes institucionales (Agudelo et al., 2010; Agudelo et al., 2014; Cisneros, 2014), nacionales (Pérez y Rincón 2013) e internacionales (Carlino, 2007; Cassany, 2004; y Herrera et al., 2014); a referentes teóricos que conjugan lo disciplinar, lo pedagógico y lo didáctico en el ámbito que los ocupa (Álvarez, 2010; Argüelles, 2014; Bajtín, 1979; Benveniste, 1977; Bogoya et al., 2000; Cassany, 2004, 2012; Charaudeau, 2004; Díaz, 2014; Martínez, 2002; Ramírez, 2007, 
entre otros); y a referentes metodológicos (Coll, 2004), lo cual les permitió emprender la ardua tarea de diseñar una propuesta de acompañamiento a los estudiantes de Licenciatura de la Facultad, en materia de competencias comunicativas; propuesta que fue avalada por la Institución.

Así, a comienzos del 2018, la Facultad asumió un compromiso con la Institución ${ }^{1}$ : implementar una estrategia de acompañamiento para los estudiantes de Licenciatura, encaminada a mejorar sus desempeños en materia de lectura, escritura y oralidad. Esta Estrategia pretende ser transversal, porque se proyecta a lo largo y ancho de cada plan de estudios ${ }^{2}$, es decir, a todos los semestres y a todas las asignaturas; sistemática, al incluir procesos y productos inherentes a la lectura, la escritura y la oralidad; y consciente, porque integra a los docentes, aquellos de quienes se espera compromiso para retroalimentar a sus estudiantes en los mencionados procesos $\mathrm{y}$ productos, desde sus respectivas asignaturas.

Es una apuesta importante, entonces, para toda la comunidad universitaria y, sobre todo, para la Facultad de Ciencias de la Educación dado que permitió estar al margen de la disposición institucional, la cual obliga a los estudiantes que ingresan a demostrar sus competencias lectoras (o matemáticas en el caso de otras facultades), ya que, en caso de no demostrarse, pueden comenzar sus estudios de pregrado, pero de manera fragmentada ${ }^{3}$.

1 Ver Artículo $3^{\circ}$ de la Resolución del Consejo Académico n.o 220 del 08 de enero de 2018, según el cual los estudiantes que ingresen a la Facultad podrán ver todos los créditos de primer semestre y no tendrán prueba clasificatoria.

2 De los programas de Licenciatura de la Facultad de Ciencias de la Educación: Pedagogía Infantil, Comunicación e Informática Educativa, Literatura y lengua castellana, y Etnoeducación.

3 Ver Artículo primero y parágrafos del Acuerdo n. 41 de diciembre 22 de 2014 del Consejo Superior de la Universidad Tecnológica de Pereira, según el cual se adoptan medidas relacionadas con los estudiantes que ingresan a la Universidad y su nivelación en competencias genéricas. 
De esta manera, desde el periodo lectivo 2018-1, todos los estudiantes de licenciatura de esta Facultad han ingresado sin ser clasificados y obligados a ver menos créditos en su primer semestre. Ello, a cambio de que la Facultad los acompañe semestre a semestre, y propenda porque mejoren sus actuaciones lingüísticas en materia de lectura, escritura y oralidad.

De este modo, cuatro semestres de implementación de la Estrategia permitieron estructurar este texto con dos pretensiones:

- Presentar la Estrategia mencionada: líneas de acción y referentes teóricos, metodológicos y procedimentales que les son inherentes.

- Entregar a la comunidad académica, específicamente a losdocentes, documentos de apoyo que se han diseñado, a propósito de la ejecución de la línea de acción más compleja, pues su dinámica exige su vinculación a la Estrategia misma, en pro de que se cumpla una de sus tres características: ser transversal en los planes de estudio de los programas de pregrado de la Facultad de Ciencias de la Educación.

La estructura de este libro se presenta en cuatro capítulos:

En el primero, se muestra el abordaje general de lo que es y lo que implica la Estrategia de acompañamiento a los estudiantes de licenciatura en materia de competencias comunicativas: sus líneas de acción, sus mecanismos de seguimiento y control, sus fundamentos teóricos y metodológicos, y los resultados esperados.

En los siguientes capítulos, se expone una compilación de los documentos de apoyo para la aplicación de los énfasis metodológicos por parte de los docentes, en tanto procesos y productos, así: 
En el segundo, los textos de lectura: análisis, resumen, síntesis, informe de lectura, lectura comentada, organizadores gráficos (cuadro sinóptico, mapa mental y mapa conceptual) y reseña crítica. En el tercero, aquellos de escritura: trabajo escrito, ensayo argumentativo, ponencia y un apartado sobre importancia de la ortografía. Y en el cuarto, aquellos de oralidad: conversatorio, exposición, mesa redonda y debate. Cada uno de estos documentos de apoyo se aborda desde lo conceptual, lo procedimental y lo valorativo, para lo cual se proponen rejillas que permiten dos valoraciones: una cualitativa (momento que retroalimenta al estudiante) y una cuantitativa (después de que haya hecho los ajustes del caso a su producto).

La compilación se realiza como actividad puntual de una de las líneas de acción de la Estrategia, justamente donde se pretende involucrar a los docentes e invitarlos a cerrar filas en pro de un acompañamiento transversal, sistemático y consciente a los estudiantes, desde sus respectivas asignaturas y a lo largo del plan de estudios del programa donde están adscritos.

Será objeto de otra publicación, dar cuenta de la ejecución de cada una de estas líneas de acción y de los resultados obtenidos en las dos fases para las cuales es concebida: la mitad y la finalización de la carrera. 


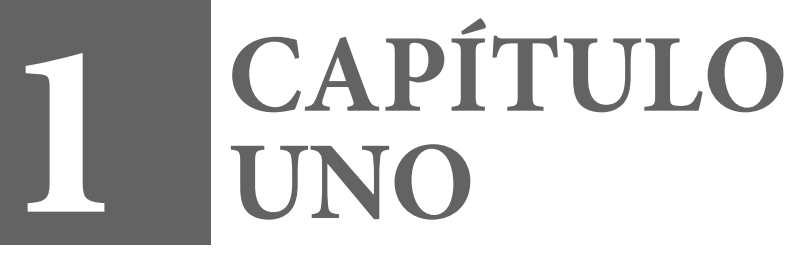




\section{Acompañamiento a estudiantes de licenciatura, en sus competencias comunicativas}

Hacerse cargo de enseñar a leer y escribir en el nivel superior es una forma de enseñar estrategias de aprendizaje.

Chalmers y Fuller (como se citó en Carlino, 2005, p. 24).

Hacerse cargo de enseñar a leer y escribir en la universidad es ayudar a los alumnos a aprender.

(Carlino, 2005, p. 25)

Una situación recurrente en la Facultad de Ciencias de la Educación de la Universidad Tecnológica de Pereira consiste en que muchos de sus estudiantes, al momento de ingreso a la Institución, muestran serias dificultades en los niveles de comprensión de lectura; factor que se les venía evaluando con una prueba de ingreso, la cual muy pocos superaban. Así mismo, alumnos de semestres más adelantados - de la misma Facultad y sus programas - también tienen problemas en materia de lectura y escritura y ni qué decir de aquellos que están a punto de graduarse que, cuando deciden realizar su proyecto de investigación, no aciertan a producir un texto medianamente cohesivo ycoherente.

Surge entonces un interrogante clave para la formación de maestros, de la cual se ocupa la Facultad, a saber: ¿Cómo acompañar a los estudiantes de Licenciatura de la Facultad de Ciencias de la Educación en materia de desempeños en su expresión oral y escrita, de tal manera que respondan con las expectativas de ingreso, de permanencia y de egreso exitoso de la Institución? 
En aras de responder este interrogante se plantea como una necesidad imperiosa la formulación e implementación de una Estrategia que apunte a la consolidación de una cultura de competencias comunicativas, cualificando las actuaciones lingüísticas de los estudiantes de los diferentes programas de licenciatura de la Facultad (Pedagogía Infantil, Comunicación e Informática Educativa, Literatura y lengua castellana, y Etnoeducación); conscientes de que estas competencias no están distantes de los procesos de adquisición y desarrollo de los conocimientos propios de cada uno de estos pregrados, cuyos fundamentos teóricos y prácticos serían impensables sin el uso de la lengua en todas sus extensiones y modalidades.

Se diseñó una estrategia con tres líneas de acción. Una de ellas presupone una correspondencia directamente proporcional entre el trabajo aunado de los docentes para acompañar los procesos y los productos de expresión oral y escrita de sus estudiantes, y la calidad de los mismos. Así, en la medida en que los estudiantes entienden que leer y escribir tiene sentido, que está dentro de sus posibilidades, y que aporta un valor agregado a sus procesos de formación en la academia, pueden verse cautivados y motivados por estas prácticas de orden superior. Por eso, a partir del desarrollo de las líneas de acción de este proyecto, enmarcadas dentro de los ejes temáticos de la Facultad (Educación y Contexto, Comunicación y Lenguaje, y Pedagogía y Didáctica), se tendrán estudiantes capaces de opinar y participar activamente en asuntos que requieren un pensamiento analítico y crítico, pues son actitudes que se fortalecen a partir de la lectura de textos académicos, de su escritura y de sus intervenciones en las diferentes modalidades de expresión oral (individual ygrupal).

Invitamos entonces al lector a reconocer, a través de este capítulo:

a) La descripción de la Estrategia de acompañamiento a los estudiantes de Licenciatura de la Facultad de Ciencias de la Educación, en materia de competencias comunicativas. 
ß) Los fundamentos metodológicos que dan pie a la operatividad de cada una de las líneas de acción de esta propuesta, donde las reflexiones de Coll (2004) acerca del discurso educacional, toman vigencia.

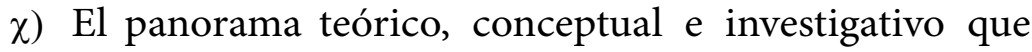
fundamenta el proyecto, desde Cassany (2004), pues este ilumina un camino sobre el cual andar al tiempo que des-andar y re-armar; asimismo, desde algunos trabajos que proveen un amplio marco interpretativo y operativo (Álvarez, 2010; Bajtín, 1979; Benveniste, 1977; Bogoya et al., 2000; Cassany, 2012; Charaudeau, 2004; Martínez, 2002; Pérez y Rincón, 2013; y Ramírez, 2007); y otros que aportan la diferencia entre géneros discursivos, tipología de textos y tipología de escritos, asunciones clave para la ejecución de esta Estrategia (Charaudeau, 2004; González Rátiva, 2008).

\subsection{Diagnóstico, retroalimentación y aplicación, claves para el desarrollo de competencias comunicativas}

La apuesta que aquí se describe surge como una respuesta después del análisis de la realidad de la Facultad de Ciencias de la Educación en relación con los desempeños lingüísticos de sus estudiantes de pregrado, tanto de los que inician sus estudios, como de los que se ubican en diferentes semestres y de los que están a punto de convertirse en egresados; igualmente, luego de la revisión de la labor adelantada en otros centros de educación superior (a manera de antecedentes) y de la lectura de bibliografía pertinente y actualizada sobre el tema.

Lo antedicho obedece pues, al punto de partida para la aplicación de una propuesta que contribuya a reducir de manera paulatina las debilidades observadas en materia de expresión oral y escrita en el ámbito académico en los estudiantes de la Facultad. Así, el objetivo que llevó al equipo de trabajo a diseñar la presente Estrategia fue retroalimentar sus procesos y productos de expresión oraly escrita a través de la interactividad 
entre profesor y alumno. Para consolidar una cultura de competencias comunicativas en y desde la Facultad de Ciencias de la Educación de la Universidad Tecnológica de Pereira, se estructuran tres líneas de acción, las cuales se pueden observar en la Figura NRo. 1 y se explican a continuación.

La línea de acción referida a los «Procesos de formación en los cursos ofrecidos al interior de los planes de estudio» de cada uno de los programas de Licenciatura de la Facultad, los cuales desde su creación tienen como objetivo desarrollar las competencias comunicativas de los estudiantes. Esta consiste en:

- Conservar en dichos cursos o asignaturas tres ejes de trabajo fundamentales: lectura, escritura y oralidad.

- Levantar un diagnóstico de rendimiento de los estudiantes en materia de comprensión de lectura (niveles: literal, interpretativo o inferencial y, valorativo y crítico) y de escritura (algunos indicadores de la cohesión, la coherencia y la ortografía) para encauzar sobre la marcha los cursos mencionados, de tal modo que se conviertan, de alguna manera, en un espacio que lee sus necesidades y propende por superar sus dificultades.

La línea de acción ahora denominada «Aplicación de énfasis metodológicos» apunta a vincular a los docentes de todas las asignaturas, de todos los semestres y de cada uno de los planes de estudio de los cuatro programas de Licenciatura de la Facultad con la misión de proporcionar retroalimentación a los estudiantesen susprocesosy productos de lectura, y de expresión oral y escrita a través de la aplicación de énfasis metodológico, dado que para el desarrollo de cualquier asignatura se acude a los procesos y productos ya mencionados. El plan de énfasis metodológico actual se muestra en la TABLA NRO. 1. Esta línea de acción garantiza la transversalidad de la Estrategia. 
FIGURA NRO. 1. Estrategia de acompañamiento a estudiantes de licenciatura: líneas de acción.

\section{TALLERES}

*Para estudiantes con marcadas dificultades

*Para compartir experiencias significativas
PROCESOS FORMATIVOS EN PREGRADO

Cursos en los planes de estudio de las licenciaturas

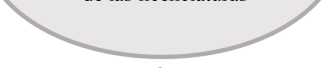

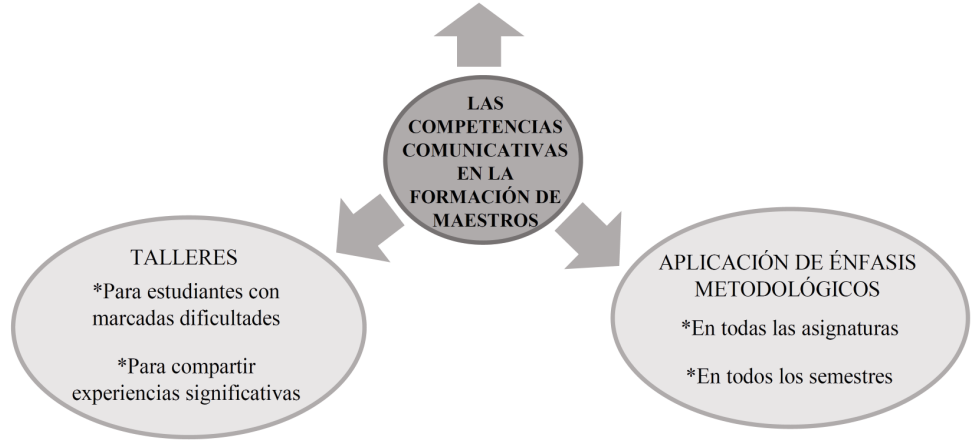

Elaboración propia.

TABLA NRO. 1. Plan de énfasis metodológico sugerido a docentes para aplicar en el aula.

\begin{tabular}{|c|c|c|c|c|c|c|c|c|}
\hline $\begin{array}{c}\text { Énfasis } \\
\text { metodológicos }\end{array}$ & $\begin{array}{c}\text { I } \\
\text { Semestre }\end{array}$ & $\begin{array}{c}\text { II } \\
\text { Semestre }\end{array}$ & $\begin{array}{c}\text { III } \\
\text { Semestre }\end{array}$ & $\begin{array}{c}\text { IV } \\
\text { Semestre }\end{array}$ & $\begin{array}{c}V \\
\text { Semestre }\end{array}$ & $\begin{array}{c}\text { VI } \\
\text { Semestre }\end{array}$ & $\begin{array}{c}\text { VII } \\
\text { Semestre }\end{array}$ & $\begin{array}{c}\text { VIII } \\
\text { Semestre }\end{array}$ \\
\hline \multirow[t]{2}{*}{ Lectura } & \multicolumn{2}{|c|}{ Análisis } & \multicolumn{2}{|c|}{ Cuadro sinóptico } & \multicolumn{2}{|c|}{ Mapa mental } & \multicolumn{2}{|c|}{ Mapa conceptual } \\
\hline & Resumen & Sintesis & Informe & e lectura & Lectura c & omentada & Reseñ & crítica \\
\hline \multirow[t]{2}{*}{ Escritura } & \multicolumn{2}{|c|}{ Trabajo escrito } & \multicolumn{4}{|c|}{ Ensayo argumentativo } & \multicolumn{2}{|c|}{ Ponencia } \\
\hline & \multicolumn{8}{|c|}{ Ortografia } \\
\hline Oralidad & Conversatorio & \multicolumn{3}{|c|}{ Exposición } & \multicolumn{2}{|c|}{ Mesa redonda } & \multicolumn{2}{|c|}{ Debate } \\
\hline
\end{tabular}

Elaboración propia.

Así, dentro de esta línea, se propende a que los profesores se vayan vinculando progresivamente a la Estrategia. Esto es, se realiza un trabajo cercano con los que orientan asignaturas en el 1 er $^{\text {er }}$ semestre (inicia con el semestre lectivo 2018-1), luego con los de $1 .^{\text {er }}$ y $2 .^{\circ}$ semestre lectivo (2018-2) para continuar con los de $1 .^{\text {er }}, 2 .^{\circ}$ y $3 .^{\text {er }}$ semestre (2019-1); después con aquellos de $1 .^{\text {er }}$, $2 .^{\circ}, 3 .^{\text {er }} \mathrm{y} 4 .^{\circ}$ semestre (2019-2); y así sucesivamente, hasta que el 
trabajo cercano se realice con todos los profesores de todos los semestres y de cada plan de estudios. Ahora bien, para hacer lo suficientemente práctica esta aplicación, se señaló una asignatura coordinadora de esta en cada semestre y cada plan de estudio. El objeto de estudio de esta asignatura ha estado vinculado con el lenguaje, preferiblemente. Esto se puede evidenciar en la TABLA NRO.2, donde se incluyen dos de los cuatro Programas de Licenciatura que surgieron como respuesta a la reforma exigida por las resoluciones nro. 02041 (2016) y nro. 18583 (2017) del Ministerio de Educación Nacional (MEN). También se pueden visualizar aquellos programas que comienzan a desmontarse por haber sido reemplazados.

TABLA NRO. 2. Asignaturas encargadas de la aplicación de los énfasis metodológicos.

\begin{tabular}{|c|c|c|c|c|}
\hline \multirow{2}{*}{$\begin{array}{l}\text { Planes de } \\
\text { estudio } \\
\text { (Periodos } \\
\text { académicos: } \\
\text { Semestres) }\end{array}$} & \multicolumn{4}{|c|}{ Programas de Licenciatura } \\
\hline & $\begin{array}{c}\text { Pedagogía infantil } \\
\text { ahora } \\
\text { Educación Básica Primaria }\end{array}$ & $\begin{array}{c}\text { Comunicación e } \\
\text { Informática educativa } \\
\text { ahora } \\
\text { Tecnología } \\
\end{array}$ & $\begin{array}{l}\text { Literatura y lengua } \\
\text { castellana }\end{array}$ & Etnoeducación \\
\hline I & $\begin{array}{l}\text { Competencias comunicativas } \\
\text { y TIC I (CBC14) }\end{array}$ & $\begin{array}{l}\text { Comprensión y producción } \\
\text { de textos I (TC143) }\end{array}$ & $\begin{array}{l}\text { Taller de lectura y } \\
\text { escritura I (EL152) }\end{array}$ & $\begin{array}{l}\text { Lenguajes y } \\
\text { comunicación } \\
\text { (ED1G4) }\end{array}$ \\
\hline II & $\begin{array}{l}\text { Competencias comunicativas } \\
\text { y TIC II (CBC23) }\end{array}$ & $\begin{array}{l}\text { Comprensión y producción } \\
\text { de textos II (TC262) }\end{array}$ & $\begin{array}{l}\text { Taller de lectura y } \\
\text { escritura II (EL152) }\end{array}$ & $\begin{array}{l}\text { Procesos históricos de } \\
\text { la formación de la } \\
\text { nación colombiana } \\
\text { (ED2A4) }\end{array}$ \\
\hline III & $\begin{array}{l}\text { Procesos de desarrollo del } \\
\text { lenguaje (PIB14) }\end{array}$ & $\begin{array}{l}\text { Teorias de la comunicación } \\
\text { y la información (LC334) }\end{array}$ & Psicolingüística (EL423) & $\begin{array}{l}\text { Métodos de } \\
\text { investigación social } \\
\text { (ED3E4) }\end{array}$ \\
\hline IV & Literatura infantil (PID23) & $\begin{array}{l}\text { Teorias de la imagen } \\
\text { (LC454) }\end{array}$ & Psicolingüística (EL423) & $\begin{array}{l}\text { Investigación en } \\
\text { contextos educativos } \\
\text { (ED4F4) }\end{array}$ \\
\hline $\mathbf{V}$ & $\begin{array}{l}\text { Construcción y Didáctica del } \\
\text { lenguaje escrito I (PIE14) }\end{array}$ & Video (LC525) & Semiótica (EL323) & $\begin{array}{l}\text { Proyecto educativo y } \\
\text { didáctico I (ED5F4) }\end{array}$ \\
\hline VI & $\begin{array}{l}\text { Construcción y Didáctica del } \\
\text { lenguaje escrito II (PIF13) }\end{array}$ & Televisión (LC625) & $\begin{array}{l}\text { Literatura } \\
\text { latinoamericana I } \\
(\text { EL623) } \\
\end{array}$ & $\begin{array}{l}\text { Proyecto educativo y } \\
\text { didáctico II (ED6H4) }\end{array}$ \\
\hline VII & $\begin{array}{l}\text { Construcción y Didáctica del } \\
\text { lenguaje escrito III (PIG13) }\end{array}$ & $\begin{array}{l}\text { Investigación formativa I } \\
\text { (LC743) }\end{array}$ & $\begin{array}{l}\text { Literatura } \\
\text { latinoamericana I } \\
\text { (EL723) }\end{array}$ & $\begin{array}{l}\text { Proyecto educativo y } \\
\text { didáctico III (FY7G4) }\end{array}$ \\
\hline VIII & $\begin{array}{l}\text { Investigación educativa II } \\
\text { (PIH44) }\end{array}$ & $\begin{array}{l}\text { Investigación formativa II } \\
\text { (LC834) }\end{array}$ & $\begin{array}{l}\text { Lingüística textual } \\
\text { (EL933) }\end{array}$ & $\begin{array}{l}\text { Proyecto educativo y } \\
\text { didáctico IV (FY8G4) }\end{array}$ \\
\hline
\end{tabular}

Elaboración propia

La línea de acción encaminada a los «Talleres» consiste en orientar un trabajo más personalizado a los estudiantes que tienen marcadas dificultades en sus procesos y productos de lectura, de escritura o de oralidad. Se incluye aquí el compartir con los alumnos de la Facultad, en general, las 
experiencias significativas del profesorado, relacionadas con las competencias comunicativas y sus vidas personales, sociales, académicas y laborales.

Esta línea se inclina entonces por la aplicación por parte del estudiante (de manera directa o indirecta) de procesos que subyacen en los productos lectores, escritores o de oralidad.

Las tres líneas de acción que estructuran esta Estrategia, proporcionan al estudiante diagnóstico, retroalimentación y aplicación; acciones clave para que su ingreso y permanencia en la Facultad se vea impactado positivamente por el acompañamiento que se les procura dar desde la misma. Esto se puede observar a través de la Figura NRO. 2.

FIGURA NRO. 2. Estrategia de acompañamiento a estudiantes de licenciatura: propósitos de sus líneas de acción.

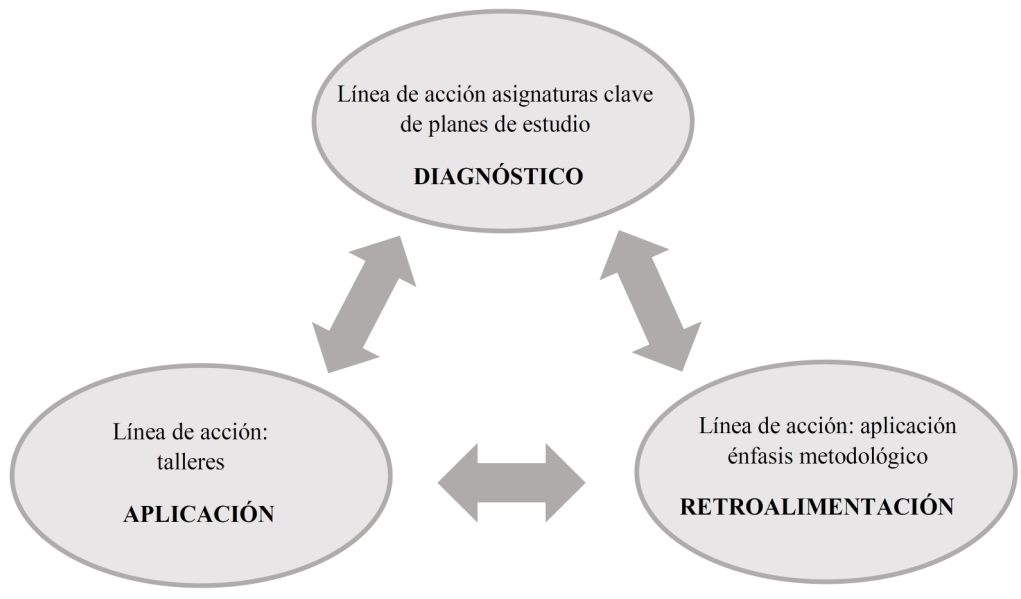

Elaboración propia.

La Estrategia aquí presentada comenzó a ejecutarse en el semestre 2018-1. La información, producto de esta labor, se ha ido consignando en archivos correspondientes a cada semestre lectivo, de la mano con la evolución que han tenido tanto los instrumentos utilizados en cada línea de acción como los procedimientos planteados al inicio de esta. 
Se realizará un primer control o un primer corte para analizar resultados de la Estrategia justo en la mitad de los planes de estudio de cada uno de los programas. En otras palabras, cuando los estudiantes que ingresaron a la Institución en el semestre lectivo 2018-1 hayan cursado su cuarto semestre de estudios, deberán responder la prueba diagnóstica que se les aplicó en ese momento.

Se espera que los estudiantes, en este pos-test, superen los resultados obtenidos en la prueba inicial, pues la premisa prefigurada por esta Estrategia a través de las tres líneas de acción es: si a los estudiantes se les acompaña, asesora, recuerda y actualiza, es decir, se les retroalimenta en sus procesos y productos lectores, escritores y orales, con un trabajo mancomunado de sus docentes, entonces van a tener desempeños mejores en relación con los presentados en el momento de ingreso a la Facultad.

Un segundo y último corte se llevará a cabo hacia el octavo semestre cuando los estudiantes que ingresaron en el periodo lectivo 2018-1 estén culminando sus estudios. Ellos responderán nuevamente la prueba diagnóstica y se espera que los resultados de esta prueba sean todavía mejores que los obtenidos en el primer corte, pues habrían trasegado más por la academia, y habrían sido acompañados desde todas las asignaturas por parte de los profesores. En esa dirección, las pruebas Saber Pro también podrían dar cuenta de los resultados de esta Estrategia.

\subsection{Fundamentos metodológicos}

\subsubsection{La interactividad en el discurso educacional: mecanismo de intervención por excelencia}

La ejecución de la Estrategia de acompañamiento a los estudiantes de Licenciatura, en materia de competencias comunicativas está atravesada, en cada una de sus líneas de acción, por la interactividad. Tal como la propone Coll (2004), esta caracteriza el discurso educacional pues ambos actores (profesor y estudiante) interactúan alrededor de una tarea. 
En la línea de acción que apunta a la «formación a través de los cursos del plan de estudios, cuyo objetivo central es el desarrollo de las competencias comunicativas» se da la interactividad cuando son desarrollados -en los respectivos semestres lectivos- los contenidos de los ejes que los estructuran: lectura, escritura y oralidad. Una actividad concreta también la constituye la explicación, a cada estudiante, sobre los resultados obtenidos en la prueba diagnóstica que se aplicó al momento del ingreso a la Institución, por parte del profesor titular de estos cursos que se ubican en primer semestre.

En la línea de acción que se dirige a la «aplicación de énfasis metodológicos», la tarea es alrededor de los procesos y productos en materia de expresión oral y escrita, y en una propuesta de transversalidad que se tiene, esto es, en un plan de énfasis metodológico (ver TABLA NRO. 1) mediante el cual se planea acompañar al estudiante durante todos los semestres de su carrera, desde todas las asignaturas. La interactividad constituye el mecanismo que permite que tanto docentes como estudiantes manejen un discurso educacional en torno a una tarea (Coll, 2004), es decir, alrededor de un producto de lectura, o de expresión oral o escrita; sin que ello implique hacer una digresión de los procesos de enseñanza y aprendizaje propios de cada una de las asignaturas. Al contrario, estos productos trabajados en el aula actúan como un énfasis metodológico, justo para no entorpecer el desarrollo normal de la asignatura.

En la línea de acción donde se plantean «Talleres dirigidos exclusivamente a los estudiantes que presenten marcadas dificultades en su comprensión de lectura y en su expresión oral y escrita», la interactividad juega un papel fundamental pues el docente va en pos de retroalimentar en el estudiante la aplicación del proceso o producto en el cual esté presentando dificultad o bajo desempeño, sea en el eje de la lectura, la escritura o la oralidad. 


\subsubsection{Tras resultados de pre-test y pos-test: técnicas cuantitativas y cualitativas}

Cohen y Manión (1990) definen el método como «las técnicas y procedimientos empleados en el proceso de obtención de datos» (p. 72). Esta Estrategia adoptó entonces el método de análisis de contenido por su intención de descubrir a través de respuestas de los estudiantes en una prueba diagnóstica de comprensión de lectura, sus desempeños en los diferentes niveles de esta área y su expresión escrita, dadas las respuestas a preguntas abiertas y semiabiertas en dichaprueba.

Además, se acude a técnicas cuantitativas y cualitativas, donde las primeras son utilizadas para tener en cuenta la frecuencia, bien sea de respuestas (en el caso de la lectura) o de usos correctos o incorrectos (en el caso de la escritura) y las segundas, para reconocer la calidad de las respuestas, en el caso de preguntas abiertas o semiabiertas, y en una correspondencia con las categorías previamente establecidas para tal análisis (tratándose de niveles de comprensión de lectura -literal, interpretativo o inferencial y valorativo o crítico-; o de escritura, en tanto las propiedades que se están valorando corresponden a la cohesión, coherencia y corrección).

Las técnicas cuantitativas ycualitativas permitirán interpretar resultados obtenidos en los diferentes momentos de evaluación de los rendimientos de los estudiantes en materia de lectura y de escritura: prueba diagnóstica de ingreso, prueba cuando hayan culminadola mitad de sus estudios de pregrado (IV semestre) y prueba hacia el final de la trayectoria educativa (VIII semestre). Así, aquellos resultados serán tanto en términos de frecuencias como de características de lo observado.

Otras técnicas que se utilizan para la recolección de la información en esta Estrategia son las rejillas o recursos que permiten el registro organizado de los resultados obtenidos por los estudiantes en cada una de las categorías y subcategorías 
valoradas ${ }^{4}$; información que la dependencia lla ma da Gestión de Tecnologías Informáticas y Sistemas de Información de la UTP utiliza como insumo para emitir los resultados de manera totalizada y gráfica (barras o torta).

De este modo, dichas técnicas requieren la rejilla como un recurso para mayor organización de los resultados obtenidos, incluyen actividades que darán paso a datos exactos, a cantidades de participantes, a respuestas para ciertas pruebas, y a comportamientos lingüísticos y pragmáticos dentro de la expresión oral y escrita, los cuales habrá que entrar a caracterizar $\mathrm{y}$ a intervenir.

\subsubsection{El plan de análisis y establecimiento de resultados}

El acompañamiento que aquí se planea para los estudiantes de la Facultad de Ciencias de la Educación se sintetiza en las siguientes líneas:

Los estudiantes que ingresan a la Facultad resuelven una prueba diagnóstica que los ubica en un rendimiento bajo, medio o alto en comprensión de lectura (niveles: literal, interpretativo o inferencial, y valorativo y crítico) y en un rendimiento bajo, medio o alto en expresión escrita (algunos indicadores de la cohesión, la coherencia y la corrección). Los resultados de esta prueba diagnóstica se les da a conocer a los alumnos, pasadas las primeras semanas de clase en las asignaturas que, dentro de cada programa, propenden por desarrollar sus competencias comunicativas. Por esta razón, sobrela marcha de estas materias, si el profesor lo considera pertinente y viable, hará algunas adecuaciones de acuerdo con dichos resultados.

Los estudiantes continúan viendo sus asignaturas del plan de estudios correspondiente, donde se espera que todos sus profesores se interesen en retroalimentar sus procesos y productos lectores y de expresión oral y escrita, a través de la

4 En una publicación posterior a esta, se dará cuenta de la ejecución de cada una de las líneas de acción, y por supuesto, en ese momento, se presentarán los instrumentos del caso. 
aplicación del plan de énfasis metodológico, el cual incluye todos los semestres de cada uno de los planes de estudio de los programas de licenciatura de la Facultad.

En un seguimiento que se les hace a los estudiantes, se determina el nivel de dificultad en sus procesos y productos lectores, escritores y de oralidad. Los criterios para inferir este nivel de dificultad son: a) Obtención de promedio bajo (3.9 o menos) semestre a semestre. b) Reprobación de asignaturas de su plan de estudios. c) Inclusión como estudiante con marcadas dificultades en lectura, escritura u oralidad, en el reporte que pasan los profesores en cada periodo académico.

A los educandos con dificultades en sus procesos y productos de lectura y de expresión oral y escrita, se les orientan algunos talleres, encaminados a disminuir tales dificultades.

En este sentido, la apuesta es que, con estas acciones, el estudiante mejore sus rendimientos en lectura, y en expresión oral y escrita. Esto en correspondencia con investigaciones realizadaspor Carlino (2007) en Argentina, quien asegura:

... la unidad de análisis se ha ampliado: de la descripción de dificultades de los alumnos para escribir en la academia, se ha pasado a indagar las relaciones entre cómo se ocupan las cátedras de la escritura y el aprendizaje de los estudiantes (s. p.).

En otras palabras, llama a poner atención a la escritura de los estudiantes desde las asignaturas y por supuesto, también a lectura y la oralidad. Por eso, dicha autora señala, citando a Chalmers y Fuller: «Hacerse cargo de enseñar a leer y escribir en el nivel superior es una forma de enseñar estrategias de aprendizaje» (p. 24), y asegura además que «Hacerse cargo de enseñar a leer y escribir en la universidad es ayudar a los alumnos a aprender» (p. 25).

Una vez el estudiante haya cursado su IV semestre se le aplica (a manera de pos-test) la prueba diagnóstica que respondió a su ingreso a la Facultad, con el fin de monitorear y comparar 
los resultados de esta con aquellos del momento del ingreso, pasados cuatro semestres de formación; esto, como un primer corte, el cual da la posibilidad de hacer control y seguimiento a dichos resultados.

Después de haber culminado sus estudios (hacia el VIII semestre de formación) se les aplica nuevamente a los alumnos la prueba diagnóstica, la cual actúa también como pos-test, y como un segundo y último corte. Así, se tendrá entonces la oportunidad de comparar los resultados de aplicación al momento de ingreso a la Facultad, hacia la mitad del proceso formativo y en el momento final del mismo. Este corresponde al impacto de la Estrategia de acompañamiento a los estudiantes de Licenciatura de la Facultad, en materia de competencias comunicativas.

Por tanto, el plan de análisis después de haber sintetizado en qué consiste la Estrategia y haber expresado a lo largo de este capítulo, los supuestos y antecedentes que motivaron su diseño, consiste en analizar los resultados del pre-test en contraste con los del pos-test; y el resultado - positivo o negativo- cotejarlo con las variables que hipotéticamente influyen en mejorarlo: a) Cursos de primer semestre específicamente orientados a desarrollar las competencias comunicativas en los estudiantes; b) concurrencia de los profesores (todos los semestres, todas las asignaturas) para garantizar la continuidad del trabajo que inician los cursos mencionados y para hacer transversal el acompañamiento (retroalimentación) a los alumnos en materia de competencias comunicativas; c) orientación de talleres a los estudiantes con marcadas dificultades en lectura y expresión oral y escrita con el fin de reforzarles los procesos de enseñanza y aprendizaje adelantados con ellos en los dos primeros espacios de formación $(a \mathrm{y} b)$.

\subsection{Fundamentos teóricos}

En cada uno de los momentos que estructuran esta Estrategia sale a flote la necesidad de clasificar los textos en relación con tres asuntos: presentar los contenidos programáticos de las 
asignaturas que van encaminadas al desarrollo de competencias comunicativas (línea de acción donde se levantará el diagnóstico inicial de desempeño de los estudiantes), conformar el plan de énfasis metodológico para lograr la transversalidad de la Estrategia (línea de acción donde se propicia la retroalimentación a los estudiantes) y diseñar los talleres para orientar a los estudiantes con dificultades marcadas en su lectura yen su expresión oral y escrita (línea de acción donde se propicia la aplicación por parte del estudiante).

Por este motivo, son necesarias las claridades conceptuales en el sentido de entender el devenir de las clasificaciones y, por qué no, las transformaciones y las imprecisiones con las cuales se han manejado en la academia misma. Se presentan entonces, en este apartado, algunas posturas desde diferentes autores y disciplinas desarrolladas alrededor de lo que comúnmente se nombra tipos de texto, entendiendo que los términos trabajados por los expertos son género discursivo, tipología textual y tipo de escrito (González Rátiva, 2008).

Teniendo en cuenta que estas no son simples clasificaciones en los términos de Ramírez (2007), se usan por una necesidad escritural de ubicación en categorías y están imbricadas en un marco comunicativo de interacción. Esta se sugiere en cada uno de los textos académicos, producidos por los estudiantes, ya sea en forma oral o escrita, los cuales responden de manera activa a la presencia de un enunciador, un enunciatario y un enunciado; triada y clasificaciones (ya mencionadas) que se explicarán en los apartados de estafundamentación.

\subsubsection{Antecedentes, problemas y precisiones sobre la tipificación del género}

Aprendemos a moldear nuestra habla en formas del género y al escuchar el habla del otro, sabemos inmediatamente, incluso desde las primeras palabras, presentir el género, adivinar el volumen [...], la estructura composicional dada, previendo el final, es decir, desde 
el inicio somos sensibles al todo discursivo que, enseguida, en el proceso de habla verterá sus diferencias. Si los géneros del discurso no existieran y si no tuviéramos su dominio, y que cada uno de nosotros tuviera que construir nuevos enunciados, el intercambio verbal sería prácticamente imposible.

Mijaíl Bajtín (1979, p. 249)

Estudiar los elementos categoriales del lenguaje para comprender clasificaciones relacionadas con la oralidad y la escritura en la enseñanza universitaria o superior, supone transversalizar múltiples fuentes de información: libros, revistas, documentales, conferencias, entre otras, donde se hallan disímiles perspectivas de acuerdo con la progresión de las Ciencias del Lenguaje y su estudio, convirtiéndose en fuentes para detonar y cultivar un buen entendimiento del asunto.

Elnivelde complejidady el tratamientoteóricoymetodológico que data de preocupaciones y reflexiones antiquísimas sobre el lenguaje, a partir del desarrollo de civilizaciones antiguas, permite comprender por qué las categorías de género, tipología textual y tipo de escrito han gozado de diversidad de miradas, enfoques, mezclas, señalamientos y distanciamientos con el trasegar del tiempo. La complejidad ha sido mayor, toda vez que según las escuelas de pensamiento y las disciplinas en donde han surgido las reflexiones han asumido matices y herencias históricas cuyas taxonomías ocasionan confusiones, pero al mismo tiempo precisiones que los avances en la relación conocimiento, lenguaje y acción permiten establecer.

Conviene aclarar que el abordaje teórico, sustancial para la Estrategia aquí presentada, se focaliza hacia la clasificación de textos y discursos académicos; esto es, hacia productos de lectura, de escritura y de oralidad en el sentido estricto. Para su precisión y desarrollo se parte, como se expone en lo sucesivo, de las reflexiones y taxonomías realizadas por los filósofos griegos en torno a diferentes géneros o tipologías discursivas, al 
tiempo que de las miradas contemporáneas que existen sobre la diferencia, la complejidad y la interdependencia entre género discursivo, tipología textual y tipo de escrito.

En efecto, el desarrollo de la ciencia y las aproximaciones teóricas para definir cualquier tipología terminológica, indistinta de la disciplina, ha contribuido para descifrar el mundo, las sociedades, las culturas, sus tramas y relaciones; naturalmente, tales audacias investigativas no podrían advertirse sin decantaciones, posibilidades o contingencias para discutir, asumir o disentir sobre diferentes posturas.

De aquí que hablar de género discursivo, tipología textual y tipo de escrito en el marco de las aproximaciones teóricas y metodológicas para una estrategia de acompañamiento en competencias comunicativas supone la ubicación en algunos antecedentes y discusiones determinantes para comprender la problemática, su claridad y su pertinencia; sobre todo, si lo que interesa es su enseñabilidad en el contexto de la educación superior, cuya dinámica demanda, en el presente siglo, la necesidad de formar sujetos senti-pensantes, críticos y argumentativos en pos de una sociedad equilibrada, justa $y$ competente en las formas de comunicar el pensamiento, de cara a la construcción social de la realidad (Berger y Luckman, 2001).

En la Antigüedad es claro que desde la Grecia arcaica han coexistido dos problemáticas de naturaleza humana y social que han determinado las posiciones para la historia de Occidente, en el marco del desarrollo del pensamiento cultural y el uso discursivo. Una, procedente de las posturas de los poetas, cuyas voces inspiradas en los dioses, tenían la responsabilidad sublime de exaltar a los héroes en sus hazañas y proezas (géneros épicos y epidícticos), y resolver los enigmas de la vida cotidiana (mitos). Esto ha posibilitado clasificar la poesía en un número de géneros que hoy se conocen como el épico, el lírico y el dramático. 
Y otra, forjada en la necesidad de administrar y/o organizar la vida de la ciudad, los ciudadanos, los conflictos comerciales, las dificultades, los obstáculos y las discusiones políticas originadas en la Grecia clásica, cuyas dinámicas tuvieron su grandeza en la cultura romana deCicerón, haciendo del discurso público un instrumento imprescindible de deliberación, persuasión, provocación, y discusión política (Charaudeau, 2004); lo que aún en nuestros días se mantiene con un cierto halo de semejanza. No igual, naturalmente, pero sí con una fuerte influencia grecorromana que ha privilegiado, cuando no instaurado, caminos «ideales» para la configuración de modos de ser, pensar, educar y actuar en Occidente. Las pruebas son muchas, solo basta pensar en las formas de proceder política, religiosa y educativamente del hombre contemporáneo para dar cuenta de las herencias universalistas, esencialistas, dogmáticas y absolutistas que rigen todavía en gran medida la vida de la polis moderna. En cuanto al problema de la clasificación de los géneros, Giraldo y Osorio (2017)aducen:

Importante destacar que la primera clasificación de géneros discursivos no literarios se la debemos a Aristóteles, quien, en su Retórica plantea que los discursos pueden ser de tres tipos: Forense o jurídico, Deliberativo y Epidíctico o de ocasión. Posteriormente, las propuestas de la retórica se desplazan de su lugar natural -el discurso institucional-a otro terreno bien diferente: el discurso escrito artístico, la literatura, reforzando las bases ya establecidas en la República de Platón y en la Poética de Aristóteles; convirtiéndose, de este modo, en un instrumento de análisis, clasificación y crítica (p. 34).

Son, pues, las dos ópticas descritas sobre la problemática de los géneros a partir de las cuales diferentes voces teóricas se han permitido reflexionar, discutir, disentir y re-clasificar, según sea su escuela y filiación teórica. Así, sus apuestas se han enmarcado en las profundidades de la facultad del lenguaje humano, los desarrollos de la lengua como institución social y la comunicación humana en tanto posibilidad de extensión en la interacción enunciativa e interdiscursiva (Bajtín, 1929; 
Benveniste, 1977; Charaudeau, 2004; Ducrot, 1985; Halliday, 1979/1998; Jakobson, 1984; Kebrat, 1980; Martínez, 2002; Ramírez, 2007; entre otros).

Indudablemente, el enfoque adoptado en este trabajo sintoniza con la segunda problemática en su intento de definir y apostar por un enfoque teórico sobre el género discursivo. En otras palabras, el dejar claro cómo, por qué y qué estructura obedece a los tipos de textos y escritos académicos que pueden incorporarse en uno u otro género.

La noción de género adoptada, como se ha explicitado, tiene su origen en la Grecia arcaica y clásica. No obstante, se teje la idea de género a partir de los postulados de Bajtín $(1929 ; 1979)$, de las investigaciones realizadas por Charaudeau (2004) y de los aportes proyectados al contexto pedagógico de Martínez (2002). Finalmente, la propuesta de Ramírez(2007), relacionada con el género discursivo a partir de las necesidades humanas para interactuar, conocer y expresar, contribuye en calidad de matriz teórica para asumir una postura sobre la enseñanza de los procesos y productos lectores y escritores, fundada en el «saber hacer» y el «hacer saber» en el contexto educativo superior, entendiendo los textos como productos de lectura y escritura para la formación académica, intelectual y crítica de los estudiantes contemporáneos; sobre todo, de aquellos que se ocupan del estudio del lenguaje, de la comunicación y del discurso en el contexto de la educación y la pedagogía, pero también de quienes transitan los ámbitos de las ciencias afines, las ciencias auxiliares, las interdisciplinas y diferentes campos de aplicación lingüística, cuyas disertaciones a partir del lenguaje y su complejidad edifican puentes e inter-relaciones enunciativas para la construcción social del mundo y sus realidades.

Naturalmente, en este proceder teórico, en función de las prácticas de enseñanza universitaria, autores como Adam (1992), Cassany (1994), Ciapuscio (1994), Maingueneau (1996), Pérez (2000), Reyes (1941, citado por el Ministerio de 
Educación Nacional, 1998), Schmidt (1978), Van Dijk (1989), aportan a la claridad contemporánea sobre la temática.

Lo anterior, no significa que no se haga alusión a algunos aspectos de corte literario, histórico o referencial, los cuales no podrían desligarse de manera tajante en la composición textual. Dado que, en el ejercicio de la oralidad o la escritura, diferentes encabalgamientos (Martínez, 2002), registros metafóricos de la vida cotidiana (Lakoff y Johnson, 1980) y alusiones a mundos posibles (Ramírez, 2007) pueden gestarse de manera natural, cuando no buscarse con fuerza intencional.

En este sentido, se puede sintetizar que en el trasegar de las clasificaciones que devienen de la Grecia antigua sobre la problemática de los géneros, se han abordado prolíficas referencias categoriales y "maneras discontinuas» ${ }^{5}$ para su clasificación, las cuales han determinado: a) contextos de habla, b) ámbitos sociales donde se tejen las relaciones, c) instituciones formales para legalizar y registrar distintos procesos de la dinámica social y política en cuyos escenarios se han tejido prácticas sociales, enmarcadas en actividades políticas, religiosas, jurídicas, científicas, educativas, cotidianas, entre otras. A su vez, estas se basan en las funciones del lenguaje tal como lo asevera Charaudeau (2004), las cuales han sido determinantes para inscribir los propios géneros discursivos y sus realizaciones a través del habla o la escritura: emotiva, conativa, fática, poética, referencial y metalingüística, funciones del lenguaje señaladas por Jakobson (1984); e instrumental, interaccional, personal, heurística, imaginativa, ideacional e interpersonal, indicadas por Halliday $(1979)^{6}$.

5 Entrecomillada la expresión «maneras discontinuas» toda vez que, en este enfoque, se consideran las sub-categorías y las formas de asumir los géneros discursivos como elementos interrelacionados e interdependientes en la realización de la producción oral o escrita; indistinta, claramente, del género en los que se circunscriba. Cada una de estas visiones y puntos de partida para la clasificación no dejan de emerger de un modo u otro en el total de la enunciación, entendida esta como la postura de quien habla o escribe, inmerso en un género determinado con sus enunciados y en una situación particular de comunicación.

6 Para una amplitud sobre el tema se recomiendan los libros: Tres momentos estelares en Lingüistica de Jaime Bernal León Gómez (1984), y Los procesos de la comunicación y del lenguaje. Fundamentación y práctica de Víctor Miguel Niño Rojas (1994). 
Por la misma línea, se enfatiza que el problema de la clasificación de los géneros también se ha fundado en la naturaleza comunicacional del intercambio verbal, tal como lo entiende Bajtín (1984). Esto es, lo natural o espontáneo como la conversación (géneros primarios) o los construidos institucionalmente como el pedagógico, el científico, el literario, el periodístico, el jurisprudencial, el teológico, el didáctico, entre otros (géneros secundarios).

En este caso, se entiende que los primeros obedecen a lo más elemental de la conversación diaria en las comunicaciones de la vida cotidiana; y los segundos, a las configuraciones complejas como el discurso político, jurídico, médico, pedagógico, entre otros, los cuales ameritan mayor disposición, cuando no estructuración, distribución, ordenamiento y lógica morfo-sintáctica en las relaciones de pensamiento. A partir de esta visión taxonómica realizada por Bajtín (1984) surge la teoría de la enunciación cuyas bases descansan en el discurso literario.

De igual modo, y siguiendo los pasos de Bajtín, autores como Benveniste (1977) han marcado su perspectiva sobre los géneros discursivos, apoyándose en el aparato formal de la enunciación, con la oposición "discurso/relato»; en cuyas distinciones este autor sostiene: «antes de la enunciación la lengua no puede ser más que ella misma» (Benveniste, 1977, p. 84). Esto sugiere que, en el entramado de los géneros discursivos, en general, y en los géneros no literarios, en particular, lo principal es el acto de la enunciación o postura de quien habla o escribe más allá de la lengua en tanto sistema o abstracción. Así, se entiende que la enunciación es el acto efectivo de realización del pensamiento exteriorizado por el hombre, pero fundamentado en un tesoro interior llamado sistema lingüístico en el que se inscriben todos los géneros discursivos, las tipologías textuales y los tipos de escrito, tal como se expone en la Figura NRO. 3. 
Por su parte, otros autores en la línea de Culioli (1976) han indicado que los géneros discursivos se deben clasificar en función de las marcas enunciativas, y tratan de definir los tipos de actividades comunicativas. Según Charaudeau (2004), estos mismos tienen un valor más o menos prototípico, tales como el narrativo, el argumentativo, el explicativo y el descriptivo, entre otros. Estos vienen a denominarse formas de organización del pensamiento en situaciones particulares de comunicación y enunciación (Martínez, 2002).

Las tensiones, en este sentido, devienen de la relación tríadica e interna entre enunciador, enunciatario y enunciado; situación que sería en niveles físico-sicológicos el vínculo externo, según la autora, entre locutor, interlocutor y ellogos ${ }^{7}$.

FIGURA NRO. 3. Sistema lingüístico: tesoro interior para la generación discursiva.

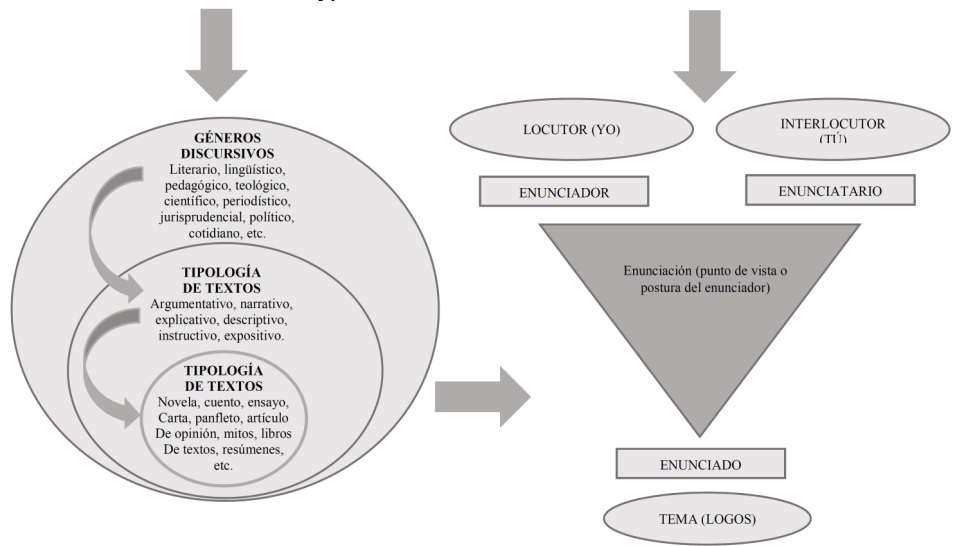

Adaptada de Pérez (2000) y Martínez (2002).

En último lugar, otras visiones, que buscan determinar un campo de producción del discurso en sintonía con textos fundantes, determinan valores de un cierto ámbito de producción discursiva, como pueden ser, según Charaudeau (2004), lo clasificado por Maingeneau (1996) en relación con el

7 Para mayor profundidad sobre el tema se recomienda la lectura de aportes de Martínez (2002) en su libro Estrategias de lectura y escritura de textos. Perspectivas teóricas y talleres, publicado por la Escuela de Ciencias del Lenguaje de la Universidad del Valle. 
discurso filosófico, el discurso científico, el discurso religioso, el discurso literario, entre otros; tipologías que los autores han definido como «discursos constituyentes» (Charaudeau 2004, p. 38).

Efectivamente, estas maneras de enfrentarse a la problemática de los géneros a través de la historia han trazado un horizonte en el cual se surca el establecimiento de puntos de partida en función del entendimiento del tema y su naturaleza. De este modo, sin ser exhaustivos, pero sí provocadores para un estudio intertextual, se trata de recordar la complejidad de esta nebulosa teórica que, como dice Charaudeau (2004): «Lo que se ha tomado en cuenta para definir esta noción se relaciona tanto con el anclaje social del discurso, con su naturaleza comunicacional, con las actividades comunicativas puestas en práctica, como con las características formales de los textos producidos» (p. 24).

Sin lugar a dudas, puede preguntarse si todos los elementos queapuntan a describir y clasificar lo concerniente a los géneros están ligados o no lo están. Más aún, como se sugiere en este apartado, cuando los asuntos del lenguaje, la comunicación y el discurso operan como discreciones de acuerdo con las situaciones particulares de comunicación, las cuales hacen parte de un todo continuo.

En otras palabras, aquello que tiene ver con lenguaje habrá de hacerse discreto o específico según los medios, los productos, los contextos y las circunstancias comunicacionales; como quiera que en el lenguaje todo es continuo e interactuante. Así, cuando decimos: «ah», «no», «ajá», «mmmm», «si Dios quiere», «fincho», "parce», «docente», «profesor», «maestro», «injusticia», «insurgente», «rebelde», o «para-político», por ejemplo, estaríamos en todos los niveles internos de la lengua (fonético-fonológico, morfológico, sintáctico, semántico), en varias interdisciplinas y transdisciplinas del lenguaje, y en los hechos de la lengua, en tanto enunciación situada (sociolingüística, semiolingüística, psicolingüística, pragmática, análisis del discurso, entre otras). 
En este marco, el sujeto competente -estudiante universitario - tendrá que saber precisar cómo, para qué y por qué dice lo que expresa oral o escrituralmente; $y$, en ello, saber determinar en qué géneros inscribirse, con qué tipologías textuales ordenar su pensamiento, qué tipo de productos lograr, y con qué intención comunicativa componerlos, según sus prácticas y relaciones socio-educativas. El docente, en directa proporción, tendrá que estar comprometido, didáctica y pedagógicamente con los procesos de lectura, escritura y oralidad tan determinantes para la formación en el contexto universitario; de cara a un posicionamiento del estudiantado en el ámbito de la actualidad administrativa, política, normativa y pedagógica de la educación, que rige el territorio nacional. De esta manera, tal como lo plantea Martínez (2002), las relaciones enunciativas cobran sentido entre el enunciador, el enunciatario y el enunciado; fundados en la visión dialógica y heteroglósica del lenguaje (Bajtín, 1979).

\subsubsection{El género discursivo: apuestas teóricas para su comprensión}

\subsubsection{Heteroglosia y dialogismo en el lenguaje (Bajtín, 1979)}

Como se ha expuesto, el concepto de género, en tanto categoría, posee varias problemáticas, cuando no raíces históricas y teóricas sobre las cuales apostar. No obstante, en esta trama de miradas la determinación por asumir una u otra focalización, o en su defecto, estar al tanto de las diversidades que co-ocurren para tomar una postura, se hace necesaria como actitud académica e investigativa fuera de toda pretensión objetiva o dogmática.

En este acontecer, la enseñabilidad de lo que significa la problemática de los géneros para la clasificación y su uso académico, se interrelaciona con una posición que valida las nociones que han construido y de-construido la complejidad del asunto-tema pero, también, se relaciona con un punto 
de vista claro que decanta propósitos teóricos, didácticos y pedagógicos para la precisión de los productos textuales de los estudiantes que, en todo caso, deben ser objeto de exigencia constante en el marco dela educación superior, y en el marco de las relaciones de enseñanza y aprendizaje; toda vez que constituyen el tejido para el aprendizaje de saberes que se cruzan, se distinguen, se refutan, se decantan y generan visiones mediadas por la subjetividad. Dado lo anterior, el respeto mutuo y democrático por las diferencias académicas, las posturas intelectuales y los estilos personales docentes que emergen en el compartir formativo deben constituir la materia prima de toda situación educativa.

De allí que sea imprescindible remitir nuevamente a Bajtín (1979) para esclarecer lo que se entiende por género discursivo en este trabajo; en especial, cuando menciona que los géneros primarios y secundarios no son más que el reconocimiento de lo espontáneo, en los que respectivamente se tiene, por un lado, lo natural de la conversación cotidiana y, por otro, la configuración compleja, intelectual o de mayor exigencia. De hecho, asumir esta postura devuelve al reconocimiento del género primario como el más importante de todos los géneros (el protolenguaje) en la medida en que, a partir de este, los géneros secundarios tienen su asidero y pueden crearse para la formalización e institucionalidad en el conglomerado de relaciones sociales, culturales, educativas, entre otras.

Además, con su visión, Bajtín (1984) sitúa ya un posicionamiento heteroglósico y dialógico de los discursos, entendido como lo polifónico o las muchas voces que puede tener un enunciado, en el primer caso, y la posibilidad de ir y venir con la palabra, en el segundo; el yo-tú discursivo es ligado por un puente en el que los enunciados son sus tramas dialogantes, y las pistas que deslizan el uno y el otro en la situación comunicativa oral o escrita constituyen las marcas deícticas o recursos gramaticales de señalamiento que aquellos trazan para la composición, interpretación e inferencias mutuas. 
Los recursos gramaticales de señalamiento (o deícticos) conforman todo el entramado cohesivo de un texto oral o escrito. Esto conlleva a una configuración coherente según el tema, la intención y las circunstancias de producción e interpretación; es decir, constituyen un puente entre el yo y el tú (locutorenunciador / interlocutor-enunciatario), quienes se deslizan entre marcas gramaticales para generar entendimientos mutuos. Así, la inteligibilidad, se logra por esta suerte de pistas que el primero lanza y el segundo descifra; pero luego, en un proceso de feedback, ocurre lo contrario. ${ }^{8}$

En consecuencia, no es gratuito que la concepción polifónica del lenguaje en Bajtín (1979) devenga de la revisión y la diferenciación realizada entre la literatura dogmática y carnavalesca. La primera, hallada en la objetividad ylinealidad de Tolstoi; y la segunda, en el carnaval y el detonante expuesto por Dostoievski. Esta distinción llevaría posteriormente a Bajtín, a dar cuenta de una teoría enunciativa para ser expandida en toda reflexión sobre las voces y el dialogismo que coocurren en múltiples discursos. Teorías sobre el lenguaje y el discurso que, por antonomasia, no han escapado a estas disertaciones tan antiquísimas como recientes acerca de la discusión sobre el uso de la lengua, en calidad de discurso. En este sentido, Bajtín (1984), en la Estética de la creación verbal, aduce:

Cada enunciado separado es, por su puesto, individual, pero cada esfera del uso de la lengua elabora sus tipos relativamente estables de enunciados, a los que denominamos géneros discursivos. La riqueza y la diversidad de los géneros discursivos son inmensas, porque las posibilidades de la actividad humana son inagotables y porque en cada esfera de la praxis existe todo un repertorio de géneros discursivos que se diferencia y crece a medida que se desarrolla y se complica la esfera misma (p. 248).

8 Para mayor amplitud sobre el tema, véase Escandell Vidal (1996, p. 20-21). 
De este modo, el concepto de género por excelencia constituye en este marco referencial, el gran espacio situacional en el que se inscriben los tipos de textos, los enunciados y los posicionamientos del sujeto hablante, cuyos cambios enunciativos determinan los géneros discursivos con los que ejerce sus comunicaciones diarias. De esta índole, el género - en tanto espacio global en el que se puede ubicar un tipo de discurso y sus diversas tipologías textuales-tiende a movilizar o desplazar géneros de un sitio a otro, sí y solo sí se presenta la injerencia de los enunciados realizados dialógicamente por los hablantes, en la oralidad o en la escritura. Así lo señala Bajtín (1984), al decir: «los cambios históricos en los estilos de la lengua están indisolublemente vinculados a los cambios de los géneros discursivos» (p. 253).

Ejemplo de ello puede hallarse cuando un hablante está en una situación concreta platicando sobre los hechos políticos actuales en su ciudad natal, pero de repente los enunciados que profiere se trasladan a la situación económica familiar que es experimentada en el momento. Se diría que los hechos enunciados y los hechos de enunciación, para este caso, lo han llevado de manera intempestiva y casi sin darse cuenta, a habitar en segundos el género político y cotidiano, simultáneamente. La lengua, en tanto sistema, posibilita entrar en uno u otro género gracias a la enunciación a partir de selecciones paradigmáticas inmediatas; esto es, a través de las actuaciones lingüísticas que se llevan a cabo rápidamente en la oralidad para seleccionar las palabras consideradas pertinentes y entrar de un tema a otro; en consecuencia, según el contexto de enunciación, para trasladarse de un género a otro.

Para el caso de la escritura, la relación polifónica y dialógica no sería diferente. En tanto un escritor toma una posición de enunciador indistinto del tipo de escrito que componga, con los tipos de textos que escoja y en el marco del género que seleccione, las marcas enunciativas determinarán precisamente el género, la estructura textual y los modos de organizar el pensamiento en concordancia con las intenciones comunicativas. En muchas 
ocasiones, un mismo enunciado puede estar cargado de varios enunciadores, lo que supone una escritura intencional para que el tú del discurso pueda descifrar cuando no aceptar o refutar. Un ejemplo concreto lo da Martínez (2005) cuando realiza un análisis polifónico a enunciado de un expresidente colombiano: «El orden será preservado, cueste lo que cueste». Dos enunciadores, según Martínez (2005) emergen aquí: uno, hablándole a los buenos ciudadanos; y otro, a los potenciales agitadores del status quo del momento. Así lo expone la autora:

El Locutor de este enunciado se presenta con una imagen de autoridad, como alguien legitimado para establecer o restablecer el orden. En este enunciado se realiza un diálogo polémico interno a través de una doble polifonía, no sólo en relación con el Enunciador sino con los Enunciatarios que se construyen, la cual es identificada a través de los actos de habla implícitos en el enunciado: - Un E1 con un PdV positivo en relación con el valor de Seguridad. E1 hace una Promesa dirigida a una actitud de respuesta de un Enunciatariol que espera del locutor estaintención de ofrecer seguridad. Es la imagen del «buen» ciudadano. - Un E2 con un PdV negativo en relación con el valor de Autoridad. E2 realiza una Amenaza dirigida a un Enunciatario2 cuya actitud de respuesta ha sido prevista por L como aquel ciudadano dispuesto a crear el desorden, a «romper el orden» propuesto por L. En el Enunciatario2 se presenta la imagen del ciudadano «inconforme» (p. 104).

La Figura Nro. 4 sintetiza este análisis que explica cómo emergen los dos enunciadores en el caso dado.

Esto traduce que, en cualquier caso, de oralidad o escritura, quien la realiza construye no solo la imagen de sí mismo, sino también, la imagen de su interlocutor (enunciatario), quien aceptará, refutará, será cómplice o negará lo dicho o escrito por un locutor- enunciador. Los enunciados que este último registre y su forma de inscribirlos en un género u otro, 
determinarán, así mismo, el tratamiento discursivo que se teje entre enunciador, enunciatario y enunciado. Aquí, según Martínez (2002), emergen una serie de tensiones que, de acuerdo con la manera como el enunciador se ubique frente al enunciatario y el enunciado (y viceversa), serán dadas en lo predictivo, intencional y apreciativo; apreciaciones que se sintetizan en las Figuras NRO. 5 y6.

Llegado a este punto, conviene aclarar que los géneros discursivos son constituidos por todos aquellos discursos que la inventiva humana se ha encargado de crear, puliry establecer en diferentes marcos epistémicos, los cuales se han servido para el entendimiento de las culturas y las sociedades en su configuración humanística, artística, científica, intelectual, política y religiosa, entre otras.

FIGURA NRO. 4. La construcción del proceso argumentativo en el discurso.

\section{ENUNCIADORES Y ENUNCIATARIOS}
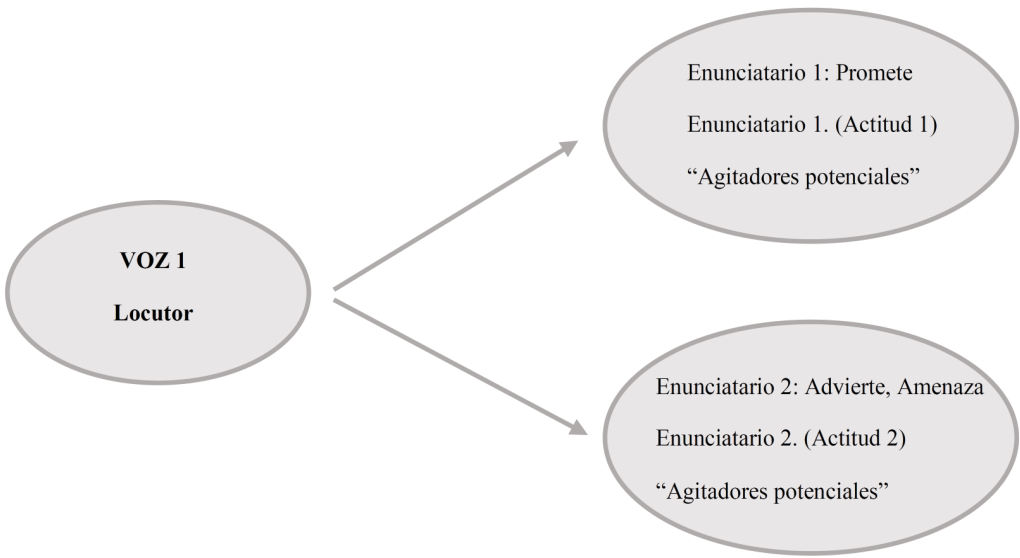

Tomada de Martínez (2005, p. 104). 
Figura NRO. 5. Tipos de géneros y tipos de textos.
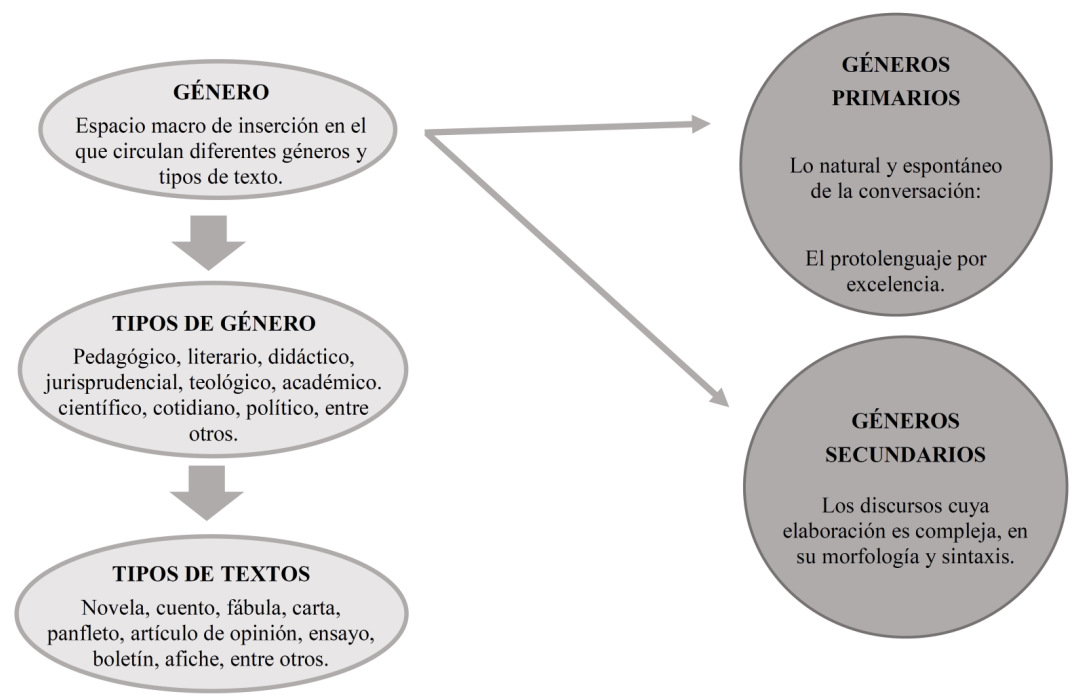

Basada en Bajtín (1979).

Por su parte, los géneros no literarios obedecen a todas aquellas composiciones intelectuales que contribuyen a expresar el pensamiento con una exposición clara, precisa y objetiva de hechos teoréticos. El caso del ensayo argumentativo, el resumen, el análisis, la reseña, entre otros -que serán presentados en los capítulos siguientes- son muestra de tipos de escritos cuyas bases complejas y objetivas se distancian de una perspectiva literaria en sí misma (cargada de subjetividad).

Deviene de lo anterior, el hecho de que, para formar estudiantes competentes en la educación superior, es necesaria una comprensión seria, limpia y profunda sobre el tema en discusión. A través de su claridad, el estudiantado, interesado por ejercer una calidad discursiva en sus procesos comunicativos orales y escritos, podrá determinar -con facilidad y sencillez- las relaciones entre los géneros clásicos emergentes, la problemática de ellos y su concepción para comprender qué son géneros discursivos. 
Figura NRo. 6. Orígenes de la polifonía y el dialogismo.

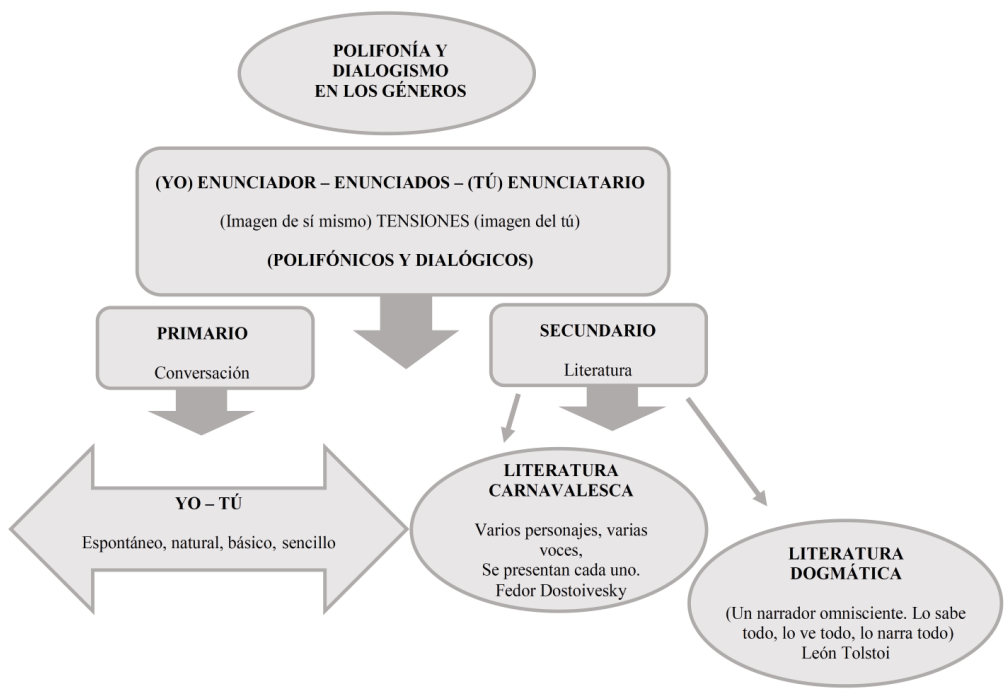

Tomada de Bajtín (1979).

En este sentido, las formas de organizar el pensamiento en medio de los géneros discursivos, en lo global, y en los géneros no literarios, en particular, muestran la concatenación necesaria cuando no connatural que puede hallarse precisamente entre género, tipos de texto y tipo de escrito. Esto quiere decir que, tanto en la oralidad como la escritura, los géneros están compuestos por tipos de textos entre los que se encuentran algunos de índole narrativa, explicativa, argumentativa, descriptiva, informativa, instructiva, entre otras; los cuales van determinando la estructura y el marco referencial del género adoptado. De esta forma, los productos de lectura y escritura, se convierten en modalidades que responden a un género $u$ otro según las especificaciones e intencionalidades manifiestas oralmente o a través de tipos de escrito concretos; pero en ocasiones, pueden albergar licencias y transgresiones muy propias de prácticas pedagógicas progresistas y alternativas en el ámbito de la educación superior, las cuales, según los propósitos educativos, muestran posibilidades diversas de construir cuando no de 
detonar textualidades y discursividades en torno a la conciencia que sobreviene de analizar con detenimiento los contextos académico, social, cultural y político.

Dichas prácticas no escapan a dificultades procedimentales y operativas cuyos embrollos teóricos y metodológicos serán abordados con ejemplos de la vida cotidiana y académica en los siguientes ítems. A su vez, se expondrá puntualmente, la importancia de asumir los géneros discursivos desde las necesidades humanas a partir del enfoque teóricometodológico de Ramírez (2007). Luego se precisarán los conceptos de tipos de textos y tipos de escritos, en función de la exposición teórica, demostrativa y didáctica, en el contexto de una propuesta teórico-práctica para la cualificación pedagógica de las competencias comunicativas en la educación superior.

\subsubsection{Interactuar, conocer y expresar: género discursivo desde las necesidades humanas}

El género discursivo desde las necesidades humanas para interactuar, conocer y expresar tiene su origen en la propuesta de Ramírez (2007), quien despliega una concepción sincrética - pero al tiempo suficiente- para explicar la ontogénesis de los géneros discursivos. En este recorrido, no escatima en las visiones teóricas que hemos planteado en los apartados anteriores, pero propone una suerte de pensamiento alrededor del tema atinente con la postura didáctica y pedagógica que en este estudio se teje; naturalmente, en función de la enseñanza sobre una de las tantas maneras posibles de apropiar el concepto de género discursivo y los tipos de textos en tanto productos de lectura, escritura y oralidad.

En los capítulos dos, tres y cuatro se abordará, en concreto, su desarrollo, a manera de demostración teórica y metodológica.

Ciertamente, a partir de este enfoque, cada vez que se genera comunicación, se habitan diferentes géneros que se presentan como dominios procedentes de voces fluctuantes en múltiples 
contextos de enunciación. Según Ramírez (2007), dependiendo de los marcos temáticos en donde se inscribe el ser humano, las comunicaciones y las acciones se imbrican en un género particular sin excepción. La explicación supone que, con un mismo sistema de lengua, se puede hacer parte de los géneros discursivos según sea el interés. Con la dinámica natural del sistema, los ámbitos, los dominios de saberes y los marcos temáticos predilectos se acentúa la afiliación. Así, el discurso, se halla en los límites del yo y el tú, de acuerdo con el aquí y el ahora del género ${ }^{9} \mathrm{y}$, entre tanto, suele ser dinámico en una conversación e, incluso, en un ejercicio escritural.

Por esta razón se asume que el género discursivo se tendría que describir y analizar según las posibilidades del orden y la orientación de los discursos (Ramírez, 2007). Estos, la mayoría de las veces, mantienen estructuras relativamente constantes. Por ejemplo, los discursos científico, literario y cotidiano responden a estructuras semánticas muy determinadas por el uso lexical y el tratamiento temático cuyas configuraciones han sido conformadas por la «necesidad de interactuar, conocer y expresar» (Ramírez, 2007, pp. 82-87).

Para el autor, los géneros discursivos no serían simples clasificaciones sino construcciones elaboradas por el ser humano dadas sus múltiples necesidades. Así, la necesidad de interactuar ha sido una forma para configurar la organización en las interrelaciones o procesos subjetivos. Al respecto Ramírez (2008) afirma:

9 El aquí y el ahora del género se concibe como la particular decisión del hablante en su interacción social de hacer parte de un género determinado, mientras realiza el acto comunicativo. Si bien es claro que en esta dinámica hay precisiones temáticas, léxicas, énfasis de dominio y constancias que determinan el género, también es cierto que, en muchas instancias contingentes, las interacciones pueden virar y los géneros desvanecerse al instante, cuando no cambiar como consecuencia de los enunciados que ingresan en la conversación o, en su defecto, que se registran en la escritura. Naturalmente, lo anterior surge con mayor ahínco en la oralidad, pues en la escritura se vuelve sobre los registros una y otra vez para precisar, adecuar o mejorar los enunciados según el género que se busque, en proceso de pre-escritura, escritura y re-escritura. 
La mayoría de relaciones intersubjetivas planteadas por los actores de los discursos son estereotipadas, hacen parte de ciertas fórmulas no sólo por las expresionesusadas, sino porlos procedimientos seguidos. Las formas de cortesía, los saludos, y todas las expresiones que se fijan en protocolos diplomáticos, militares y religiosos; igualmente, ciertos discursos complejos en donde la inclusión del lenguaje verbal y formas simbólicas en general dependen del ritual que se sigue. Hay algunos medios estables como los utilizados en relaciones entre el médico y el paciente, entre el papá y el hijo, entre los soldados y sus superiores; pero aparecen otras en las cuales el autor no conoce el rol del otro, o cuando no son discursos hechos para un interlocutor especial, como sucede en la escritura con mayor frecuencia (pp. 83-84).

La necesidad de expresión es otro de los elementos desde el cual se derivan los géneros discursivos, puesto que el ser humano no solo posee conocimientos teóricos logo-céntricos, sino también saberes sobre cómo actuar con ellos y cómo aplicarlos (Ramírez, 2007). Así, en este proceder, ellos tienen exclusividades, preferencias y emotividades en el tratamiento de temas; situación que varía - sin lugar a dudas- de una persona a otra, en la medida de sus compromisos diarios. De este modo, crea especificidades en los estilos de relación, de expresión y de enunciación con los otros. La literatura en este ámbito es una muestra fehaciente de la necesidad que ha tenido el hombre para dar cuenta de su sensibilidad frente a los estadios sociales y a las épocas.

Finalmente, la necesidad de conocer ha constituido otro de los factores que ha posibilitado al hombre solucionar diversidad de problemas para transformar su mundo y sobrevivir en él. Es una necesidad que ha habilitado para el avance, el progreso y la inventiva funcional para las sociedades, las culturas y sus desarrollos más destacados. No en todas, claro está, como podría discutirse desde un punto de vista sociológico, 
económico o político, pero sí en el ámbito global de la historia de la humanidad y sus transformaciones. Referente a esta necesidad, Ramírez (2007) considera:

El conocimiento también aparece como apremiante al hombre para su supervivencia. Es una actividad basada en el desarrollo fisiológico de un pensamiento que le permite explorar, transformar y crear mundos. Pero el conocimiento ha sido una necesidad que, desde el punto de vista dela cantidad de personas involucradas, ha generado más procesos de adaptación que de transformación de los mundos. Y no todas las épocas, ni todos los grupos sociales han logrado igual grado de desarrollo en este sentido. La necesidad del conocimiento, por ejemplo, comienza en aquellas etapas de reconocimiento perceptual en el cual los rudimentos son completamente adaptativos hasta terminar en las etapas más racionales y conceptuales. Es el paso de la sensación al concepto y sus respectivas combinaciones y etapas. Es la etapa correspondiente a los grandes desarrollos de la ciencia y la tecnología. Y el desarrollo del conocimiento ha sido un imperativo para la supervivencia del hombre yaunque cada vez se hace más complejo y más acertado en responder a las urgencias del hombre, sin embargo, desde ahí surgen otros problemas y otras necesidades relacionadas con los nuevos estilos de vida y con los desarrollos e intereses económicos (p. 86).

Desde esta concepción de género originada en la reflexión sobre las necesidades humanas, no se pone en tela de juicio el hecho de que cada vez que se apalabra el mundo, se seleccionan los enunciados en función del género, las tipologías textuales y la situación particular de enunciación-significación, relacionados con los inter-locutores pertinentes, cuando no enunciatarios genuinos; todo esto, en función de los propósitos del acto comunicativo, los contextos y los intereses copartidarios de los mensajes. 
Esto significa que las necesidades humanas de interactuar, expresar y conocer son una suerte de condiciones humanas connaturales que le han permitido al ser humano pensar, simbolizar y particularizar elementos propios de dichas necesidades con el propósito de gestar sentidos y amalgamarlos en los géneros con los que se ha comprometido y en los cuales se ha circunscrito con sus acciones en el mundo de la vida. En esta dirección, se habla de los discursos cotidianos, literarios y científicos, en tanto géneros discursivos.

En lo global, para Ramírez (2007), los discursos se convierten en distribuciones cuyos sentidos se conforman con las voces de los ámbitos y dominios de saber en alguna de las funciones posibles. En consecuencia, para abordar los discursos literarios, científicos y cotidianos, por ejemplo, es necesario tener en cuenta el ámbito en el cual se construye la significación en función de un sentido con una dominancia (epistémica, ética o estética), de la característica de ese saber o conocimiento (conceptual, imagen, imagen poética), de la relación entre contenidos explícitos e implícitos (metafóricos, metonímicos y sinecdocales), de la estructura sintáctica entre las voces (argumentación, narración, descripción), tal como se sintetiza en la TABla Nro. 3.

TABLA NRo. 3. Géneros discursivos pensados desde las necesidades humanas.

\begin{tabular}{|c|c|c|c|}
\hline \multicolumn{4}{|c|}{ GENSADOS DESDE LAS NECESIDADES HUMANAS } \\
\hline $\begin{array}{c}\text { Necesidades } \\
\text { Humanas }\end{array}$ & $\begin{array}{c}\text { Géneros } \\
\text { discursivos }\end{array}$ & $\begin{array}{c}\text { Base } \\
\text { orientadora }\end{array}$ & $\begin{array}{c}\text { Procesos de significación y } \\
\text { sentido } \\
\text { (relación entre contenidos) } \\
\text { Interactuar }\end{array}$ \\
\hline Conocer & Discurso cotidiano & Imágenes/ Ética & $\begin{array}{c}\text { Procesos sinecdocales, } \\
\text { reduccionistas }\end{array}$ \\
\hline Expresar & Discurso cientifico & Proporciones/ Conceptos/ Verdad & $\begin{array}{c}\text { Procesos metonímicos, } \\
\text { argumentados }\end{array}$ \\
\hline
\end{tabular}

Tomada de Ramírez (2007). 


\subsubsection{Tipologías textuales: formas de organizar el pensamiento y el discurso}

Las tipologías textuales se entienden como formas de organizar el pensamiento y el discurso en los diversos procesos de comunicación en los que el ser humano se compromete, dependiendo el ámbito, los dominios y los interlocutores. Esto opera ciertamente, para la oralidad y la escritura, en otrora denominadas tecnologías (Ong, 1982) que, para la época contemporánea, han constituido los más grandes desarrollos suscitados por la inventiva humana, cuya dinámica ha venido ganando complejidad en la medida del avance cognoscitivo, social, cultural ytecnológico.

En este sentido, las tipologías textuales constituyen modos de organización del pensamiento que obedecen a circunstancias relativas de los papeles sociales (Halliday, 1979), desempeñados porla competencia del hablante en su discurrir. En esta dinámica las estructuras suelen ser fijadas como modos de organizar con claridad el pensamiento; es decir, son posibilidades que según Ramírez (2007) devienen de las necesidades de interacción, expresión, conocimiento y comunicación de los hablantes en una sociedad, tal como se ha expuesto.

Lo dicho se podría traducir en que los tipos de texto o modos de organización del pensamiento (argumentación, descripción, explicación, instrucción, exposición, narración, entre otros) aparecen como voces distribuidas en el discurso que pueden verse inscritas y/o comprometidas con encabalgamientos o simultaneidades; lo cual, regularmente, el enunciador puede resolver cuando prioriza uno u otro en correspondencia con su interés comunicativo y su accionar discursivo en lo oral o en lo escrito.

Por ejemplo, en las prácticas pedagógicas que detonan ideas nuevas, un docente podrá plantear la re-escritura de un cuento tradicional a partir de referentes culturales actuales. Esto es, incorporar en la narrativa de un cuento de los hermanos 
Grimm como «Hansel y Gretel», aspectos sociales, culturales, psicológicos y políticos actuales, donde la transcreación o transtextualidad contribuyan a la elaboración de un pensamiento creativo, crítico y argumentativo sobre la realidad social de nuestro país. Esto significa, que no se estaría frentea un tipo de texto narrativo en sentido estricto, si lo que se pretende es comunicar el malestar social, la indiferencia del Estado sobre el mundo rural, la falta de oportunidades o el oportunismo de la gente en el ámbito social y familiar, entre otros.

En tal caso, se estaría frente a un tipo de texto argumentativo desde el punto de vista de la intencionalidad, cuyos elementos lexicales y puntos de vista configurarían una posición crítica del autor frente a los temas referidos. El estudiante podría optar por un ensayo argumentativo para manifestar su pensamiento sobre la temática. No obstante, el uso de un tipo de escrito como este y su reconfiguración para denunciar una inconformidad social, de ningún modo podría situarse ingenuamente en un tipo de texto narrativo tradicional.

Si bien conservaría una organización semántica (superestructura, macro estructura), ya que mantendría fundamentalmente la secuencia de acontecimientos del original en cuanto a su esquema, el eje temporal, las acciones, los desequilibrios y la búsqueda de nuevos equilibrios; sería claro que esta manera de proceder se convertiría en una transgresión argumentada que posibilitaría nuevos pensamientos y conexiones en el estudiante; a través de un tipo de escrito que correspondería a la estructura del cuento. Es to supone, que el tipo de género discursivo variaría de 1 a 2 , como se muestra en las Figuras Nro. 7 y 8.

\subsubsection{Tipos de escrito y/o productos textuales}

En correspondencia con lo planteado, se asumen los tipos de escrito como productos finales que desarrolla un autor en su inscripción del yo consciente, intencionado, y relacionado con 
un género discursivo y unos tipos textuales; en la mayoría de los casos estos son determinados, priorizados o simplemente demandados por el género, la estructura semántica y la intención comunicativa del escrito en particular (Pérez, 2000).

Lo antedicho, significa que los tipos de escrito gozan de estructuras e inscripciones relativamente estables en correspondencia con el enunciador de modo que cuando alguien profiere, produce o crea un tipo de escrito, de manera natural, se ha escogido o se ha inscrito (en) un género, un(os) tipo(s) de texto(s) o modo(s) de organizar el pensamiento; al tiempo, emerge el registro lexical, intencional y propositivo referido a la construcción de la imagen del Yo y del Tú, y de lo que el primero - a través del tema enunciado- quiere que el segundo asimile, interprete, refute, recree, piense o modele. En últimas, emerge lo que desea que en el otro del discurso (lector - destinatario) ocurra, se mueva, se genere o se efectúe para ganar en reacciones anímicas de diferente orden, a saber, pragmáticas y siempre contextuales.

En el ejemplo expuesto en el ítem anterior sobre la posibilidad argumentativa a través del cuento de Hansel y Gretel, nótese que si se suprimiera el cuento de la estructura textual, este elemento podría ser reemplazado por un análisis sobre las dificultades sociales, las condiciones de vida de la población rural y las familias en donde el papá o la mamá, en un determinado hogar, podrían no ser el padre o la madre biológicos de uno o todos los hijos que hagan parte del núcleo familiar -entre otras situaciones- y no se modificaría la intención comunicativa, ni la estructura del tipo de texto argumentativo. 
FigURA NRO. 7. Estructura del cuento tradicional (creación clásica).

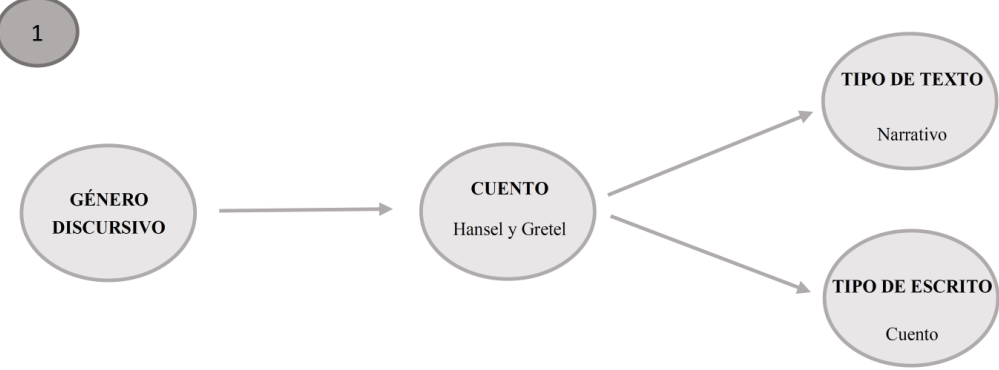

Basada en Pérez Abril (2000).

Figura NRo. 8. Estructura del cuento tradicional (creación contemporánea).

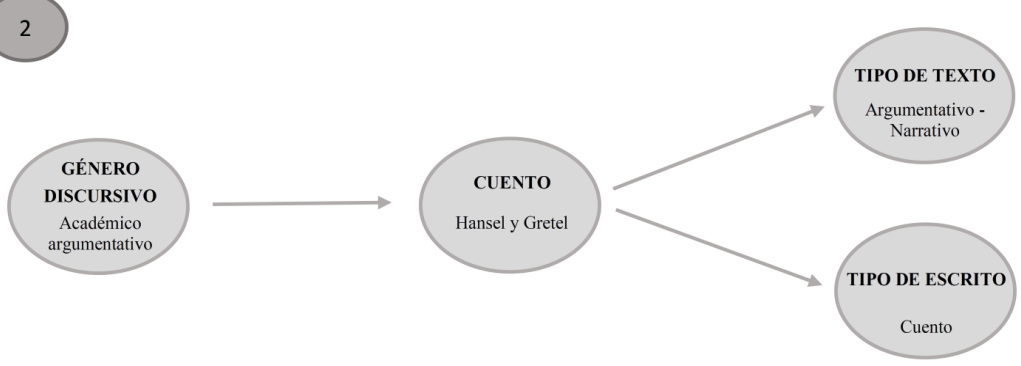

Basada en Pérez Abril (2000)

Lo que interesa demostrar a la luz de los planteamientos de Pérez (2000), es la pertinencia de las categorías teóricas para acercarse tanto a la enseñanza como al aprendizaje del análisis y la producción de textos, como precisa a continuación y como se muestra en la TABLA NRO. 4.

Si no contáramos con la distinción entre tipo de discurso, tipo de texto y tipo de escrito, el ejercicio de caracterizar e interpretar textos donde hay encabalgamientos e intenciones comunicativas diversas, podría resultar ambiguo, pues podría confundirse el nivel del discurso con el nivel del texto o con 
el nivel del escrito. En otras palabras, podrían confundirse las características pragmáticas con las características textuales o con las características formales (p. 118).

TABLA NRo. 4. Características del discurso, del texto y del escrito.

\begin{tabular}{|c|c|c|}
\hline DISCURSO & TEXTO & ESCRITO \\
\hline Pragmáticas \\
(Sentidos/ Acciones) & $\begin{array}{c}\text { Textuales } \\
\text { Formales }\end{array}$ \\
Coherencia & $\begin{array}{c}\text { (Significados/ súper-estructuras/ Pertinencia } \\
\text { y/o encabalgamientos de las tipologias } \\
\text { textuales o formas de organizar el } \\
\text { pensamiento: narrativa, argumentativa, } \\
\text { descriptiva, explicativa, instructiva, etc.) }\end{array}$ & $\begin{array}{c}\text { Cohesión } \\
\text { (Formas de composición lexical/ macro- } \\
\text { estructuras, micro-estructuras) }\end{array}$ \\
\hline & Cohesión & \\
\hline
\end{tabular}

Tomada de Pérez (2000, pp. 119-120).

Teniendo como premisa básica que los elementos planteados en este trabajo se refieren a la formación de licenciados, vale destacar que los estudiantes están en la obligación de acercarse con rigurosidad tanto al metalenguaje como a la aplicación adecuada de las categorías en los procesos de composición textual y actuación oral. Esto es, a los productos de lectura, de escritura y de oralidad, expuestos en los capítulos posteriores los cuales son fundamentales para que el futuro docente piense los escenarios pedagógicos y defina sus metodologías de trabajo al interior del aula; de acuerdo con los contextos educativos, los niveles y los grados en los que interactuará con sus saberes. En este sentido, la recomendación de Pérez (2000) resulta imprescindible para el campo dela educación superior, al decir:

A los docentes nos corresponde definir qué categorías teóricas y qué niveles de formalización, a nivel del metalenguaje, deben abordarse en diferentes momentos del trabajo pedagógico. Es muy difícil decidir en qué momento se introduce $\mathrm{X}$ o $\mathrm{Y}$ categoría, pues esto lo define el proyecto de escritura en el que se está inmerso; es allí donde aparecen las necesidades concretas de apropiación y construcción de categorías y de acercamiento a los metalenguajes. Hay casos en que los niños de primaria, en 
ciertos escenarios de escritura auténtica, o en ciertos proyectos que vinculan sus intereses reales, alcanzan niveles complejos de dominio de categorías pertinentes para su proceso de escritura. De este modo, no puede pensarse que la complejidad de las categorías corresponda con las edades o etapas de desarrollo de los niños (p. 119).

La referencia anterior lanza entonces una conclusión determinante. Las edades no pueden ser condiciones indispensables para lograr la cualificación en uno $\mathrm{u}$ otro tipo de escrito, texto o discurso. De esta consideración se desprende asertivamente que la distinción categorial planteada y sus respectivas características constituyen una apuesta en tanto herramienta de trabajo pedagógico para el docente, en función de establecer referentes para la aplicación en el ámbito escolar. Entre tantas taxonomías, esta es una de las que podría implementarse como posibilidad en aras de lograr claridad teórica y práctica. Sin embargo, sea cual sea el género, la tipología textual o el tipo de escrito por los que se opte siempre será problemático, pues según Pérez (2000), «lo que se gane en claridad y profundidad, se perderá en extensión» (p. 120).

En la TABla NRo. 5 se resume lo expuesto en este capítulo. No obstante, se sintetiza la información relativa a una pedagogía del discurso y del texto en el marco de la estrategia de acompañamiento en competencias comunicativas para la educación superior, desde un enfoque transversal.

Finalmente, se considera que ser competente a nivel discursivo supone estar en condiciones de situarse de manera clara frente a los discursos e interpretar las variables que pueden definir los niveles de significado y sentido; puesto que pensar en la formación del pensamiento crítico y la toma de posición como enunciadores pasa indefectiblemente por estos procesos (Pérez, 2000). 
Cabe resaltar que estos referentes teóricos están permeando todas y cada una de las líneas de acción mencionadas en el apartado inicial de este capítulo, las cuales, respectivamente, permiten el diagnóstico, la retroalimentación y la aplicación, como elementos clave en el desarrollo de las competencias comunicativas de los estudiantes de Licenciatura.

TABLA NRO. 5. Tipología textual

\begin{tabular}{|c|c|c|}
\hline $\begin{array}{c}\text { TIPO DE DISCURSO } \\
\text { (Intención de comunicación) }\end{array}$ & $\begin{array}{c}\text { TIPO DE TEXTO } \\
\text { (Súper-estructura) }\end{array}$ & $\begin{array}{c}\text { TIPO DE ESCRITO } \\
\text { (Actualización del discurso) }\end{array}$ \\
\hline Describir & Descriptivo & $\begin{array}{c}\text { Noticias, cartas, cuentos, novelas, } \\
\text { monólogos, postales... }\end{array}$ \\
\hline Explicar (Exponer) & Explicativo & $\begin{array}{c}\text { Manuales, libros de texto, conferencias, } \\
\text { tratados, resúmenes, reseñas... }\end{array}$ \\
\hline Contar (Narrar) & Narrativo & $\begin{array}{c}\text { Cuentos, mitos, novelas, canciones, } \\
\text { fábulas, leyendas, biografias, crónicas, } \\
\text { diarios, reportajes... }\end{array}$ \\
\hline Persuadir (Argumentar) & Argumentativo & $\begin{array}{c}\text { Ensayo, disertación, editorial, poema, } \\
\text { publicidad, cartas, artículo, cuento... }\end{array}$ \\
\hline Exhortar (Forzar a) & Instructivo & $\begin{array}{c}\text { Recetas de cocina, reglamentos, códigos, } \\
\text { anuales de empleo de aparatos, } \\
\text { instructivos, carta, propagandas... }\end{array}$ \\
\hline Informar & & $\begin{array}{c}\text { Boletín de prensa, noticia, carta, tarjeta de } \\
\text { invitación, afiche, aviso, aviso clasificado, } \\
\text { e-mail... }\end{array}$ \\
\hline
\end{tabular}

Tomada de Pérez (2000). ${ }^{10}$

10 Véase «Hacia una pedagogía del discurso: elementos para pensar la competencia argumentativa en los procesos de escritura en la educación básica» del libro de Mauricio Pérez Abril, llamado Competencias y proyecto pedagógico (2000, pp. 107-138). Para su construcción, el autor referencia los trabajos realizados por teóricos como Adam (1992), Cassany (1994), Van Dijk (1989) y Schmidt (1978). 


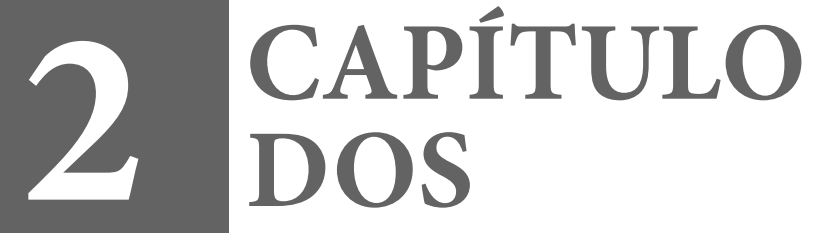




\section{Procesos y PRODUCTOS DE LECTURA}

La lectura es una actividad compleja en tanto involucra «no solo tareas lingüísticas o procesos psicológicos, sino también prácticas socioculturales» (Cassany, 2006,p. 10). En este sentido, constituye una práctica que requiere la decodificación del texto (asociado con la posibilidad de oralizar la grafía), pero que no se limita a ello. La lectura demanda la aplicación de un conjunto de destrezas mentales que permiten comprender el contenido o dar cuenta del valor semántico de las palabras, tanto en su particularidad como en su conjunto. Pero, además, esta implica la conjunción del autor y del lector a través de la mediación que representa el texto en una especie de diálogo intersubjetivo que se verifica y actualiza teniendo en cuenta los contextos de producción y de interpretación en donde se ubican ambos sujetos, como se indica en la Figura NRO. 9.

FIGURA NRO. 9. Producción e interpretación textual: relación autor-lector.
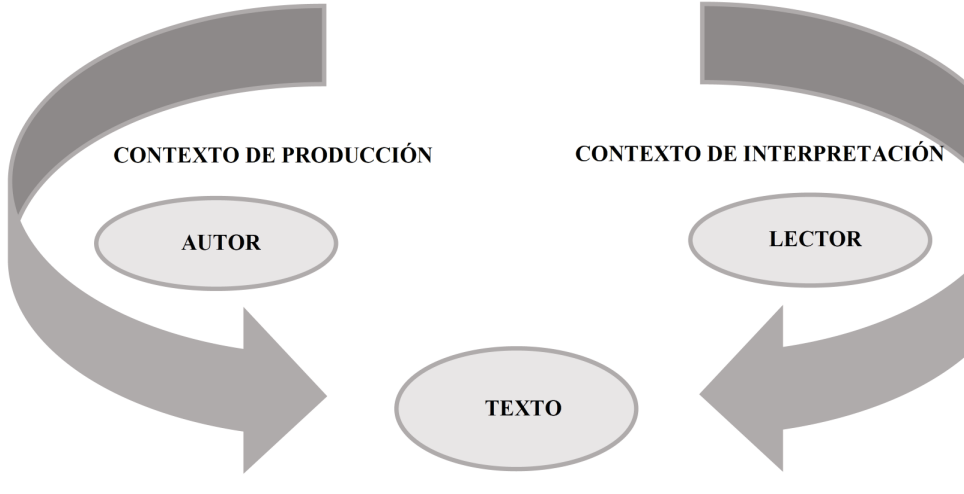

CONTEXTO DE INTERPRETACIÓN

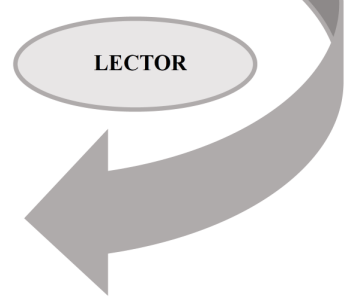

Elaboración propia.

Este diálogo tiene la capacidad de trascender las limitaciones de tiempo y espacio en la medida que permite al lector acceder a la información producida por personas pertenecientes a épocas diferentes y ubicadas en territorios distantes. Así pues, 
el texto constituye el lugar verbal de encuentro donde se reúne el autor y el lector. El autor es un creador en primera instancia porque idea el mensaje, codifica el discurso, lo elabora y lo emite. El lector por su parte, a través de un ejercicio de interpretación, re-crea el texto decodificando, lo comprende y asigna sentido al mismo. Ahora bien, ni el autor ni el lector son sujetos abstractos. Cada uno de ellos se encuentra inmerso en un contexto concreto (determinado por la cultura, la sociedad, las relaciones económicas, la ideología, entre otros) desde donde ejerce su función de creación o de interpretación, respectivamente.

Desde su irrupción en la historia de la especie humana, la lectura se convirtió en una actividad esencial para el desarrollo del sujeto y de las comunidades. Ella encarna una forma de comunicación que permite el acceso a información cognitiva y emocional. A lo largo de la historia la lectura ha sido quizá una de las herramientas más eficaces para transmitir la cultura y acceder al conocimiento científico. El lugar central que esta actividad ocupa en la escuela (en todos los niveles de formación) obedece justamente a esta condición: «Leer no es una destreza cognitiva independiente de personas y contextos, sino una herramienta para actuar en sociedad, un instrumento para mejorar las condiciones de vida del aprendiz» (Cassany, 2006, p.68).

Por eso, en el mundo contemporáneo, la lectura es una actividad que compete a toda persona. Enormes volúmenes de información inundan la realidad actual. Las universidades y sus espacios de formación no escapan a ello. La comunicación del conocimiento (de la cual participan investigadores, docentes y estudiantes) pasa la mayoría de las veces por la lectura de material escrito en medios analógicos o digitales. Ya no basta la escucha atenta que los discípulos aplicaban sobre el discurso oral del maestro - como era propio de la universidad en sus orígenes- la modernidad erigió al libro como objeto central para el acceso a la cultura y a la ciencia, y todavía hoy la lectura resulta determinante en este empeño. 
En realidad, no existe una única ruta para desarrollar un proceso de lectura. En este caso la norma la constituyen las variantes derivadas del propósito de lectura, de las características del texto leído o incluso de las preferencias o estilo de desempeño del lector. Sin embargo, cuando de la lectura de textos con fines académicos se trata, resulta útil seguir un proceso lógico relacionado con el abordaje del texto, asumiendo los niveles de profundidad en su comprensión, comolo ilustra la FigURA NRO. 10.

El primer contacto con el texto suele hacerse desde la lectura literal que centra su atención en la decodificación del texto. Luego viene la comprensión literal con la identificación de los contenidos explícitos. Posteriormente, está la comprensión interpretativa o inferencial que da cuenta del material implícito. Por último, se encuentra la comprensión crítica, críticovalorativa o crítico-intertextual que permite elaborar juicios a propósito del texto o establecer las relaciones entre el mismo y otros textos o entre él y los contextos de producción y de lectura.

Figura NRo. 10. Niveles de lectura.

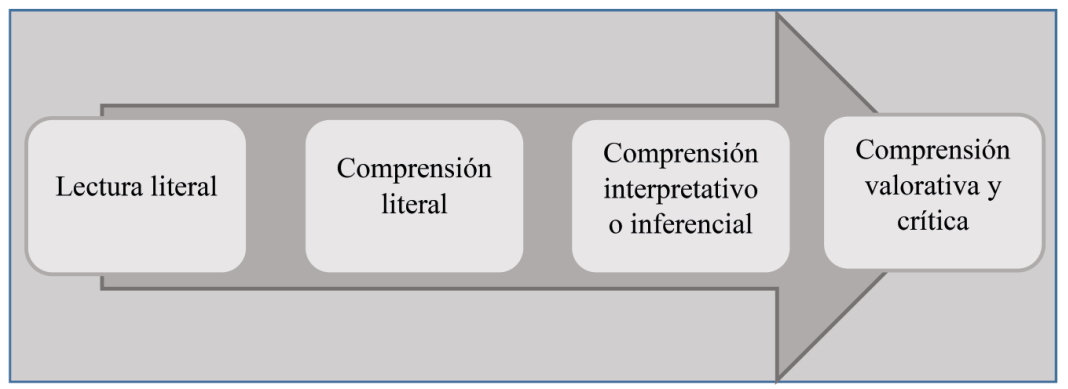

Elaboración propia.

Así, de acuerdo con estas consideraciones generales, cada uno de estos niveles cuenta con indicadores que podrían ser de utilidad, cuando de reconocerlos se trata. Estos se pueden apreciar en la TABLA NRO. 6 . 
TABLA NRO. 6. Indicadores de cada uno de los niveles de lectura.

\begin{tabular}{|c|c|c|c|}
\hline Lectura literal & Comprensión literal & $\begin{array}{c}\text { Comprensión interpretativa } \\
\text { o } \\
\text { Inferencial }\end{array}$ & $\begin{array}{c}\text { Comprensión crítica, } \\
\text { crítico-valorativa } \\
o \\
\text { crítico-intertextual }\end{array}$ \\
\hline $\begin{array}{l}\text { - Rasgos prosódicos. } \\
\text { - Operaciones } \\
\text { lingüísticas. }\end{array}$ & $\begin{array}{l}\text { - Competencia lexical. } \\
\text { - Reconocimiento de } \\
\text { constituyentes esenciales } \\
\text { de la oración. } \\
\text { - Conocimiento de } \\
\text { funciones de elementos } \\
\text { cohesivos. } \\
\text { - Construcción literal } \\
\text { seguida. } \\
\text { - Construcción con deixis. } \\
\text { - Construcción con sujeto } \\
\text { al inicio y sus predicados } \\
\text { a lo largo del texto. } \\
\text { - Referencia en voz pasiva } \\
\text { a algo que está en el texto } \\
\text { en voz activa. }\end{array}$ & $\begin{array}{l}\text { - Cromatización. } \\
\text { - Cuantificadores. } \\
\text { - Expresiones con sentido } \\
\text { figurado. } \\
\text { - Señalizadores. } \\
\text { - Contextualización. } \\
\text { - Campos semánticos. } \\
\text { - Macroproposiciones. } \\
\text { - Intenciones. } \\
\text { - Implícitos en las } \\
\text { imágenes. }\end{array}$ & $\begin{array}{l}\text { - } \begin{array}{l}\text { Reconocimiento de } \\
\text { características del } \\
\text { contexto de producción. }\end{array} \\
\text { - } \begin{array}{l}\text { Reconocimiento de } \\
\text { características del } \\
\text { contexto de lectura. }\end{array} \\
\text { - Manejo del nivel } \\
\text { superestructural del } \\
\text { texto. }\end{array}$ \\
\hline
\end{tabular}

Tomada de: Agudelo et al. (2014).

\subsection{Análisis}

\subsubsection{Concepto}

En sentido general, analizar es descomponer un todo en sus partes constitutivas para reconocer los principios de su realización; en este caso el todo es un texto, y lo que quiere el lector es ahondar en sus condiciones de realización en cuanto a su estructura (microestructura, macroestructura y superestructura) y a su significación. Una definición más sistémica es la que aporta el psicólogo ruso Shardakov (1968) al decir:

Es un proceso, orientado hacia un fin determinado, de los elementos que integran los objetos o los fenómenos de la realidad, en sus rasgos o propiedades, así como de los nexos y relaciones que existen entre ellos, con el fin de estudiarlos con 
mayor amplitud y profundidad y conseguir un conocimiento integral de estos objetos y fenómenos (como se citó en Agudelo et al., 2014, p. 84).

En los libros se encuentra, sobre todo, análisis literario y análisis lingüístico, lo cual no es de nuestro interés en este proceso, razón por la cual acudimos a los aportes del pedagogo Shardakov, tanto en su definición de análisis como en los pasos que señala para su realización.

\subsubsection{Pasos para su elaboración}

Para comprender de manera completa y rigurosa un texto convendría seguir los pasos que se señalan en la FIGURA NRO. 11 (Shardakov, como se citó en Agudelo et al., 2014), los cuales todavía tienen vigencia.

Figura NRo. 11. Pasos para la realización del análisis.

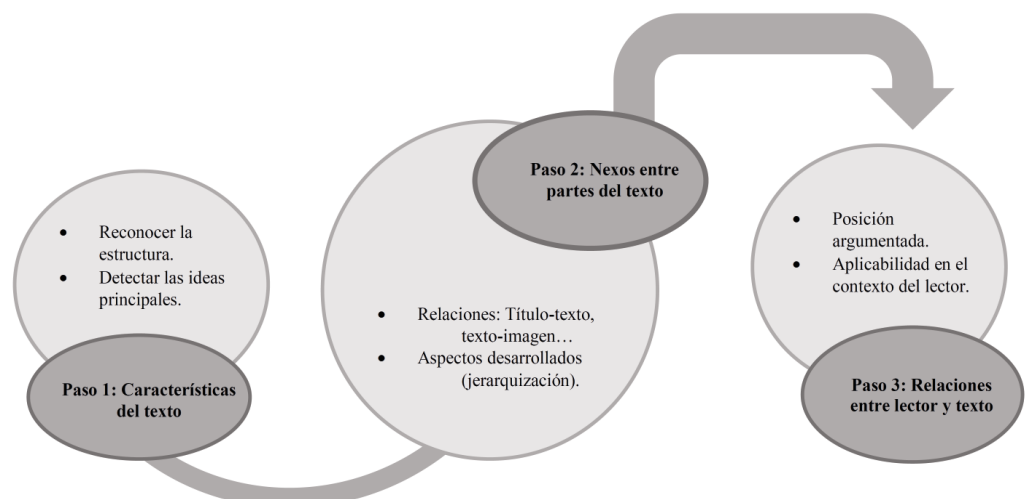

Tomado de Agudelo et al. (2014).

\subsubsection{Primer paso: rasgos, propiedades y características}

Estructura. Reconocer las partes que conforman el todo. En el caso de un texto (libro, artículo, proyecto, entre otros), consiste en identificar títulos, subtítulos, epígrafes, pies de 
página, prólogo, introducción, párrafos ampliados, imágenes, tablas, mapas, gráficos, conclusiones, bibliografía, apéndice, anexos, colofón, entre otras partes; también las divisiones del texto en unidades de menor a mayor categoría (párrafos, partes o apartados, capítulos, tomos, volúmenes). A continuación, se amplían algunos de estos apartados del texto:

- Título: Enunciado breve que encabeza el texto y, de manera literal o metafórica, da pistas sobre su contenido.

- Epígrafe: Escrito breve que precede el desarrollo de un texto o de una parte considerable del mismo. Se ubica luego del título, por lo general alineado a la derecha y con tamaño y tipo de letra diferentes. El autor de un epígrafe puede ser el mismo autor del texto u otro que él decida retomar; en tal caso se remata el epígrafe con el nombre del autor y en algunos casos se escribe el título del libro en el cual se encuentra esta cita; o si lo dicho en el epígrafe es muy conocido o es un adagio popular no se cita autor alguno. Su lectura atenta aporta elementos importantes que revelan los propósitos que tiene quien escribe.

- Capítulos: Son unidades mayores en las cuales se divide un libro. Tienen como fin organizar los contenidos y orientar al lector.

- Subtítulos: Frases sintéticas que sirven para orientar al lector en las diferentes partes del capítulo, cuando los hay, o del texto como un todo integral. Aunque no hay una regla específica sobre su uso, por lo general se acostumbra a ubicar cada subtítulo a una distancia mínima de cinco o seis párrafos, aunque su uso queda a discreción del autor. Cada subtítulo da origen a un apartado.

- Imágenes: Son ilustraciones (dibujos, caricaturas, fotografías, entre otras opciones) que, si están 
acompañando al texto, es porque de alguna manera guardan relación con la intención comunicativa del mismo.

- Colofón: «Anotación al final de los libros, indicando el nombre del impresor y el lugary fecha de la impresión» (Real Academia española [DRAE], 2019).

- Prólogo: «Texto preliminar de un libro, escrito por el autor o por otra persona, que sirve de introducción a su lectura» (DRAE, 2019).

Ideas principales. De acuerdo con las divisiones identificadas en la estructura, se determinan las ideas principales. Si se está analizando un texto corto, lo adecuado es que haya máximo una idea principal por cada párrafo, pero si es un texto extenso, esta labor no es práctica, por lo tanto, estas habría que extraerlas por cada subtítulo, capítulo o apartado claramente diferenciado.

Como se pudo observar, este primer paso desglosa el todo (el texto) en sus partes constitutivas en cuanto a la forma o presentación (estructura del texto) y en cuanto a su contenido (ideas que expresa el autor).

\subsubsection{Segundo paso: los nexos}

Es la relación que se da entre las partes del texto. En este sentido, las que pueden darse son:

- Relación título-texto. En palabras de Eco (como se citó en Rojas, 1996, p. 61), el título es al ensayo como la dirección a la carta. Este principio se acoge aquí para todo texto, aquel debe representar, sintetizar o presentar el texto. Sin embargo -por descuido en esta elaboración- en algunos casos se pueden presentar títulos que exceden el alcance del texto o se quedan cortos en relación con el contenido de este. Al analizar 
la relación título-texto y tener detectado uno de los casos mencionados, es importante explicitar porqué se considera así tal relación.

- Relación imagen-texto. Esta puede calificarse como complementaria, suplementaria o estética. En el primer caso, la relación se caracteriza por el aporte de elementos nuevos al texto por parte de la imagen. Estos guardan relación íntima con este. En el segundo caso, la imagen brinda elementos que no están explícitos en el texto, pero facilitan su comprensión. Y en el tercero -quizá el menos deseado- implica asumir la imagen como un elemento decorativo tomado al azar, el cual no contribuye a la comprensión del texto.

- Jerarquización de ideas. Obedece a las prioridades que tuvo el autor al expresar sus ideas. Se determina estableciendo los aspectos a los cuales se refiere con las ideas principales a lo largo de todo el texto, en el orden adoptado. En este paso se trasciende el reconocimiento de las partes del texto para ahondar en su significado, en tanto lo permita la correlación entre sus partes.

\subsubsection{Tercer paso: las relaciones}

Relaciones que se dan entre el lector y el texto se pueden establecer atendiendo a todas o algunas de las siguientes acciones:

- Calificar el texto dando la justificación del caso.

- Expresar acuerdo o desacuerdo con el texto, argumentando tal posición.

- Comparar con conocimientos previos (puede complementarse, refutarse o reafirmarse). 
- Buscar la aplicabilidad que tiene el texto con el contexto vivido por el lector (en categorías temporales y espaciales).

- Citar experiencias directas (propias) o indirectas (ajenas) a propósito del textoleído. En este paso también se ahonda en el significado del texto sin ceñirse a las partes del mismo, sino a las relaciones que puede establecer el lector entre el texto y sus conocimientos, sus experiencias, sus expectativas y su contexto.

\subsubsection{Presentación (estructura formal)}

Para su presentación formal se pueden tener en cuenta los tres pasos antes expuestos pues, de otro modo, se haría un análisis incompleto. Estos pasos sugieren que un proceso de este tipo es un todo integrador que permite una apropiación del texto desde abordajes complementarios, loscuales se sugiere quevayan desde lo formal hasta las diversas relaciones posiblemente identificables entre el texto y el contexto.

En la academia, usualmente, los profesores proponen a los estudiantesanalizar los textos lanzando preguntas que se ubican en uno, algunos o todos los pasos vistos para la realización de dicho análisis, pero sin conciencia de qué parte del texto se está abordando: la construcción misma ( $1 .^{\text {er }}$ paso), la significación intrínseca (2. ${ }^{\circ}$ paso) o el impacto en el lector ( $3 .^{\text {er }}$ paso). Por lo anterior, Agudelo et al. (2014) proponen realizar los análisis incluyendo los tres pasos mencionados, como se presenta a continuación:

\subsubsection{Título}

Opciones: conservar el mismo título del texto fuente, aclarando entre paréntesis la clase de texto («análisis») o crear un título nuevo, el cual debe ser representativo de lo que se escribió como análisis. 


\subsubsection{Contenido}

Parte introductoria: En el comienzo del texto, con una redacción cohesionada y fluida, se presentan los aspectos formales que permiten identificar el escrito analizado (título, autor o autores, lugar de edición, editorial, entre otros datos que lo identifiquen).

Desarrollo: En esta parte va el resultado de los pasos mencionados, en su orden de realización. En primer lugar, debe aparecer el desglose de las partes del texto y las ideas principales del mismo, agrupadas según las subdivisiones que presente (volúmenes, capítulos, subtítulos, entre otras). En segundo lugar, debe mostrar el resultado de la identificación de las relaciones entre las partes del texto analizado; si este es extenso, estas podrían trabajarse teniendo en cuenta las subdivisiones del mismo. En tercer lugar, se debe evidenciar la realización de algunas o todas las acciones en pos del establecimiento de la relación texto-lector.

Estas tres partes que estructuran el desarrollo del análisis van relacionadas entre sí (se recomienda establecer esta relación con conectores) y siempre haciendo alusión no solo a las partes que conforman el texto, sino también al autor del mismo.

\subsubsection{Autoría del texto}

Cabe anotar que el autor del análisis es quien lo realiza, dato que es necesario explicitar.

\subsubsection{Evaluación}

Lo dicho sobre el ANÁlisis, se incluye en la rejilla que se presenta en la TABLA NRO. 7. Su valoración desde lo cualitativo permite el registro de observaciones y sugerencias de ajuste; desde lo cuantitativo, constituye un instrumento para brindar una calificación (nota) que dé cuenta de la calidad del trabajo 
que se revisa. Para determinar si se califica uno u otro valor, pueden consultarse las respectivas equivalencias en la TABLA NRO. 8.

TABLA NRO. 7. Rejilla para la valoración del análisis.

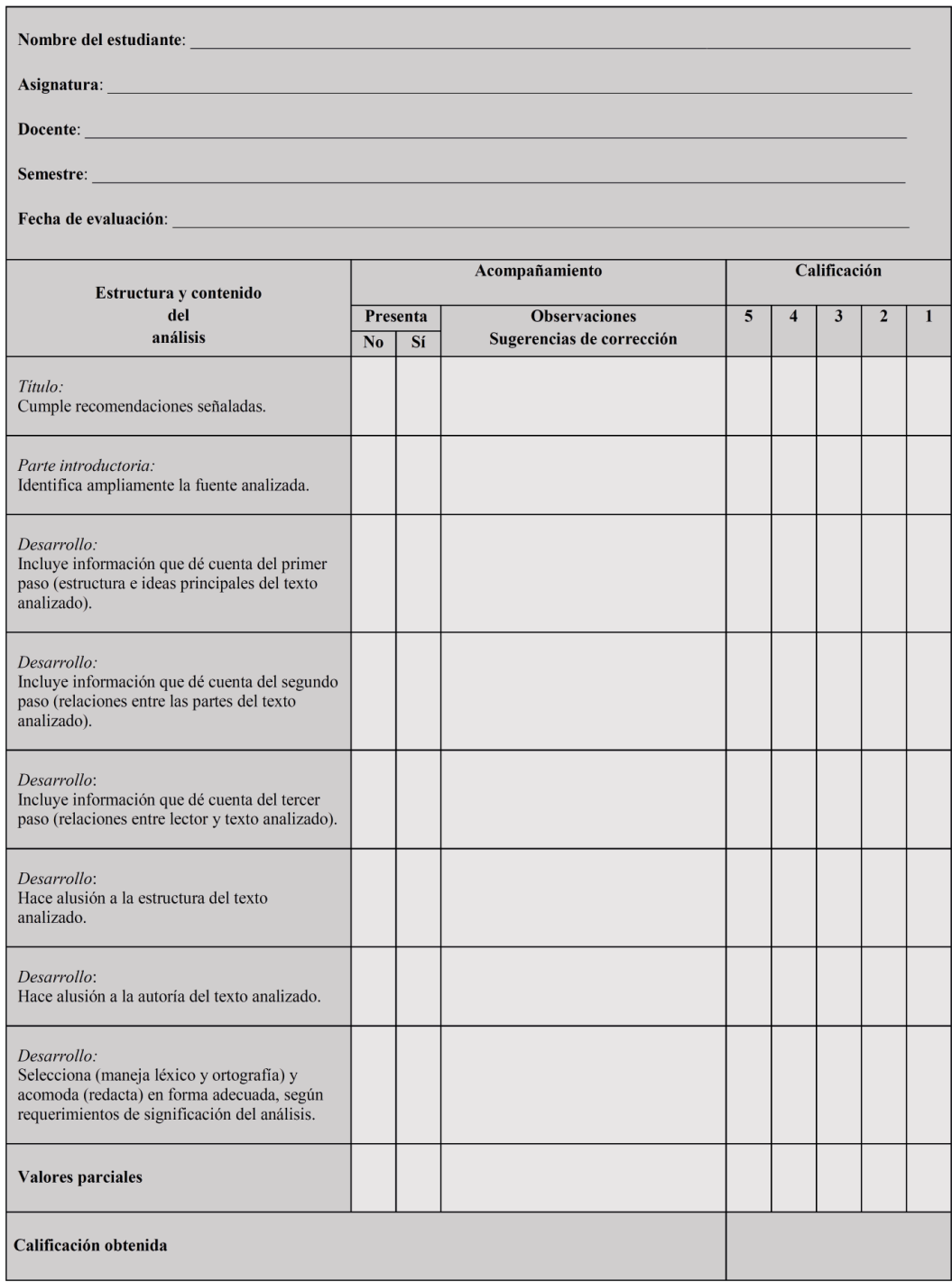

Elaboración propia. 
TABLA NRO. 8. Equivalencias para la valoración del análisis.

\begin{tabular}{|c|l|c|c|}
\hline Puntos & \multicolumn{1}{|c|}{$\begin{array}{c}\text { Equivalencias } \\
\text { en términos cualitativos }\end{array}$} & $\begin{array}{c}\text { Escala } \\
\text { puntos obtenidos }\end{array}$ & $\begin{array}{c}\text { Nota } \\
\text { Obtenida }\end{array}$ \\
\hline 5 & Excelente: altamente adecuado. & 40 & 5.0 \\
\hline 4 & Bueno: adecuado (algunos errores u omisiones). & 32 & 4.0 \\
\hline 3 & Regular: inadecuado (muchos errores u omisiones). & 24 & 3.0 \\
\hline 2 & $\begin{array}{l}\text { Deficiente: no usa el recurso esperado o todos sus usos } \\
\text { son incorrectos. }\end{array}$ & 16 & 2.0 \\
\hline 1 & No sabe o no responde. & 8 & 1.0 \\
\hline
\end{tabular}

Elaboración propia.

\subsection{Resumen}

\subsubsection{Concepto}

Es una operación indispensable en la comprensión y elaboración de textos, o sea, en la lectura y la escritura. No solo se leen textos, sino también otras producciones que combinen palabras con diferentes sistemas de significación (como las películas, las presentaciones multimedia, los documentales, entre otras opciones) o, inclusive, aquellas que carezcan de palabras (secuencias con caricaturas, cine mudo, entre otras).

La palabra resumen proviene del verbo latino resumo, conformado por la palabra sumo que significa «tomar para sí, coger, escoger». En esa dirección, gracias al prefijo intensivo re-, adquiere etimológicamente el sentido de «retomar»y «elegir».

\subsubsection{Procedimiento para su elaboración}

El resumen tiene unas características que le permiten dar cuenta de la fuente que lo inspira: breve, claro y objetivo. Antes de hacer un resumen es necesario realizar el primer paso señalado para el análisis con el fin de detectar las ideas principales, pues el resumen es la reagrupación de estas ideas. De ahí que, en la capacidad que se tiene para identificar las ideas principales radica buena parte de la calidad del mismo. Los 
siguientes son algunos aspectos generales que deben tenerse en cuenta cuando se va a realizar un resumen:

- El texto obtenido como resumen, es más corto que el texto fuente.

- De un mismo texto-fuente o acontecimiento se pueden hacer múltiples resúmenes.

- De los múltiples resúmenes de un mismo texto fuente, uno puede ser mejor que los otros en cuanto a objetividad, claridad yprecisión.

- El hacer resúmenes no es una actividad intelectual mecánica; exige habilidad, motivación y creatividad.

Un buen resumen se trabaja con base en las denominadas macrorreglas propuestas por el holandés Teun A. Van Dijk (1989) como se aprecia en la Figura NRO. 12.

\subsubsection{Presentación (estructura formal)}

Para su presentación formal, se puede tener en cuenta la estructura propuesta por Agudelo et al. (2014) como sigue:

\subsubsection{Título}

Se puede tomar una de las siguientes opciones: a) Copiar el título del texto que se quiere resumir y enseguida escribir la palabra resumen entre paréntesis. b) Se escribe un título de creación propia, representativo del texto fuente.

\subsubsection{Contenido}

Parte introductoria: En el comienzo del texto, con una redacción cohesionada y fluida, se presentan los aspectos formales que permiten identificar el texto resumido (título, 
autor o autores, lugar de edición, editorial, entre otros datos de identificación).

Desarrollo: Un paso previo a esta presentación formal del resumen consiste en el reconocimiento de las ideas principales tratadas en el texto leído. Por eso, en la realización del resumen, se reagrupan dichas ideas en una composición textual, cuidándose de presentarlas en el mismo orden en que el autor las expuso, de dar a entender en qué partes del texto se encuentran, y de reiterar, cada vez que sea posible, quién es el autor de la obra fuente que se esté resumiendo.

FigURA NRO. 12. Macrorreglas para la realización del resumen.

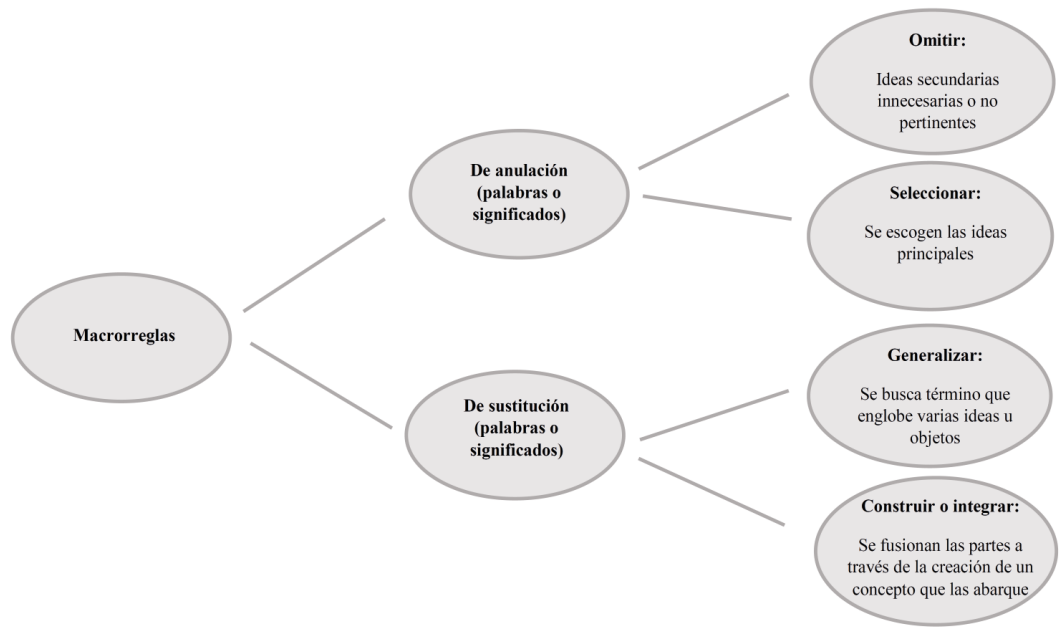

Tomada de Van Dijk (como se citó en Agudelo et al., 2014, p.168).

Este contenido del resumen, tanto la parte introductoria como el desarrollo, va a continuación del título en una prosa seguida dividida en párrafos. Cuando el texto fuente es extenso y presente algunas subdivisiones (subtítulos, capítulos, partes, entre otras), en el ejercicio de reagrupación de las ideas principales, puede optarse por subtitular el resumen conservando las mismas subdivisiones de la fuente o, en todo caso, dar cuenta de ellas en su redacción. Estas partes que estructuran el desarrollo del resumen van relacionadas entre 
sí, lo cual se puede reflejar con conectores, y siempre haciendo alusión no solo a las partes que conforman el texto, sino también al autor del mismo.

\subsubsection{Autoría del texto}

Es justo reconocer que el autor del resumen es quien lo realiza, por tanto, conviene explicitar esta información.

\subsubsection{Evaluación}

Lo dicho sobre el RESUMEN se incluye en la rejilla que se presenta en la TABLA NRO. 9. Su valoración desde lo cualitativo permite el registro de observaciones y sugerencias de ajuste; desde lo cuantitativo, constituye un instrumento para brindar una calificación (nota) que dé cuenta de la calidad del trabajo que se revisa. Para determinar si se califica uno u otro valor, pueden consultarse las respectivas equivalencias en la TABLA NRO. 10.

TABLA NRO. 9. Rejilla para la valoración del resumen.

\begin{tabular}{|c|c|c|c|c|c|c|c|}
\hline \multicolumn{8}{|l|}{$\begin{array}{l}\text { Nombre del estudiante: } \\
\text { Asignatura: }\end{array}$} \\
\hline \multicolumn{8}{|l|}{ Docente: } \\
\hline \multicolumn{8}{|l|}{ Semestre: } \\
\hline \multicolumn{8}{|l|}{ Fecha de evaluación: } \\
\hline \multirow{3}{*}{$\begin{array}{l}\text { Estructura y contenido } \\
\text { del } \\
\text { resumen }\end{array}$} & \multicolumn{3}{|r|}{ Acompañamiento } & \multicolumn{4}{|c|}{ Calificación } \\
\hline & Pres & & Observaciones & 5 & 4 & 3 & 2 \\
\hline & No & Sí & Sugerencias de corrección & & & & \\
\hline \multicolumn{8}{|l|}{$\begin{array}{l}\text { Titulo: } \\
\text { Cumple recomendaciones señaladas. }\end{array}$} \\
\hline \multicolumn{8}{|l|}{$\begin{array}{l}\text { Parte introductoria: } \\
\text { Identifica ampliamente la fuente resumida. }\end{array}$} \\
\hline \multicolumn{8}{|l|}{$\begin{array}{l}\text { Desarrollo: } \\
\text { Da cuenta de las ideas principales expuestas en } \\
\text { el texto resumido. }\end{array}$} \\
\hline $\begin{array}{l}\text { Desarrollo: } \\
\text { Hace alusión a la estructura del texto resumido. }\end{array}$ & & & & & & & \\
\hline
\end{tabular}




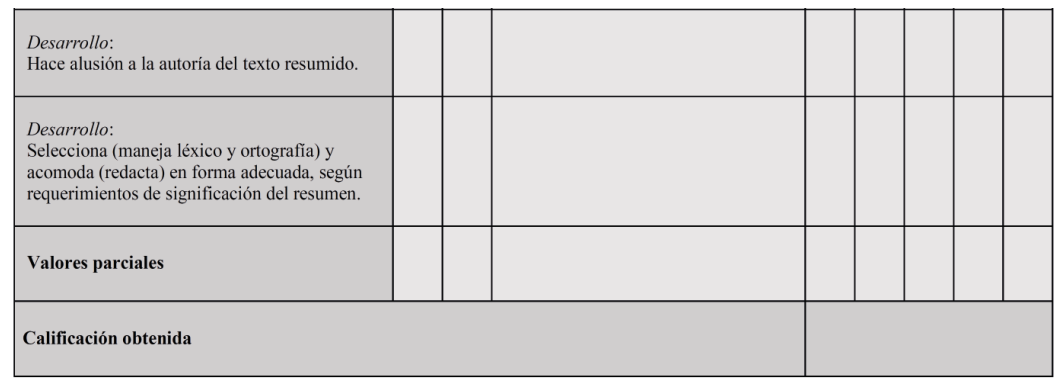

Elaboración propia.

TABLA NRO. 10. Equivalencias para la valoración del resumen.

\begin{tabular}{|c|l|c|c|}
\hline Puntos & \multicolumn{1}{|c|}{$\begin{array}{c}\text { Equivalencias } \\
\text { en términos cualitativos }\end{array}$} & $\begin{array}{c}\text { Escala } \\
\text { puntos obtenidos }\end{array}$ & $\begin{array}{c}\text { Nota } \\
\text { Obtenida }\end{array}$ \\
\hline 5 & Excelente: altamente adecuado. & 30 & 5.0 \\
\hline 4 & Bueno: adecuado (algunos errores u omisiones). & 24 & 4.0 \\
\hline 3 & Regular: inadecuado (muchos errores u omisiones). & 18 & 3.0 \\
\hline 2 & $\begin{array}{l}\text { Deficiente: no usa el recurso esperado o todos sus usos } \\
\text { son incorrectos. }\end{array}$ & 12 & 2.0 \\
\hline 1 & No sabe o no responde. & 6 & 1.0 \\
\hline
\end{tabular}

Elaboración propia.

\subsection{Síntesis}

\subsubsection{Concepto}

La síntesis es una actividad cognoscitiva reflectora que se manifiesta en el establecimiento de cualidades y propiedades de carácter único entre los elementos posibles del conjunto; en la determinación entre ellos de un sentido único y definido, en su unión y en su enlace, lo cual da como resultado la obtención de un nuevo objeto o fenómeno (Shardakov, 1968).

\subsubsection{Procedimiento para su elaboración}

Antes de hacer una síntesis, es necesario realizar el primer paso señalado para el análisis en lo relacionado con detectar las ideas principales del texto. Luego, reconocer los aspectos ampliados en dichas ideas 
principales, pues la síntesis es la reagrupación de los aspectos desarrollados en un texto, a través de dichas ideas. Como resultado, se obtendrá otro producto que dé cuenta de dichos aspectos principales allí tratados. Este debe ser breve y representativo del texto fuente, o sea, del texto sintetizado. Por lo tanto, la síntesis de determinado texto será menos extensa que el resumen del mismo.

\subsubsection{Presentación (estructura formal)}

$\mathrm{Al}$ presentar una síntesis se pueden tener en cuenta las partes propuestas por Agudelo et al. (2014):

\subsubsection{Título}

Hay dos opciones: se coloca el mismo título del texto fuente, seguido de la clase de texto entre paréntesis («síntesis»). La otra opción es crear un título nuevo, representativo de aquello que se escribió como síntesis.

\subsubsection{Contenido}

Parte introductoria: En el comienzo del texto con una redacción cohesionada y fluida, se presentan los aspectos formales que permiten identificar el texto sintetizado (título, autor o autores, lugar de edición, editorial, entre otros datos de identificación).

Desarrollo: Un paso previo a esta presentación formal de la síntesis consiste en el reconocimiento de los aspectos tratados en el texto leído. Por eso, en su realización, se reagrupan dichos aspectos en una composición textual. Estos deben presentarse en el mismo orden en que el autor los expuso. De esta índole, el autor de la síntesis debe dar a entender en qué partes del texto se encuentran y reiterar, cada vez que sea posible, quién es el autor de la obra fuente que se está sintetizando. 
Este contenido de la síntesis (tanto la parte introductoria como el desarrollo) va a continuación del título, en una prosa seguida dividida en párrafos. Cuando el texto fuente es extenso y presente algunas subdivisiones (subtítulos, capítulos, partes, entre otras), en el ejercicio de reagrupación de los aspectos, se puede optar por subtitular la síntesis, conservando las mismas subdivisiones o, en todo caso, dar cuenta de ellas en su redacción.

\subsubsection{Autoría del texto}

Es justo reconocer que el autor de la síntesis es quien la realiza, por tanto, conviene explicitar esta información.

\subsubsection{Evaluación}

Lo dicho en las anteriores líneas sobre el proceso de sínTESIS, se incluye en la rejilla que se presenta en la TABLA NRO. 11. Su valoración desde lo cualitativo busca ofrecer la oportunidad de registrar observaciones y sugerencias de ajuste; desde lo cuantitativo, constituye un instrumento para brindar una calificación (nota) que dé cuenta de la calidad del trabajo que se revisa. Para determinar si se califica uno u otro valor, pueden consultarse las respectivas equivalencias en la TABLA NRO. 12.

TABLA NRO. 11. Rejilla para la valoración de la síntesis.

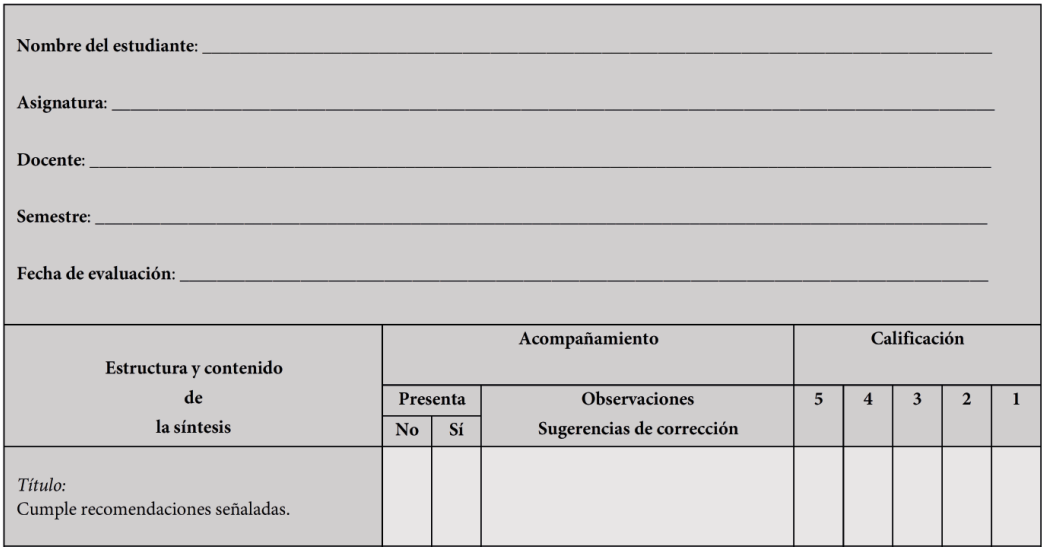




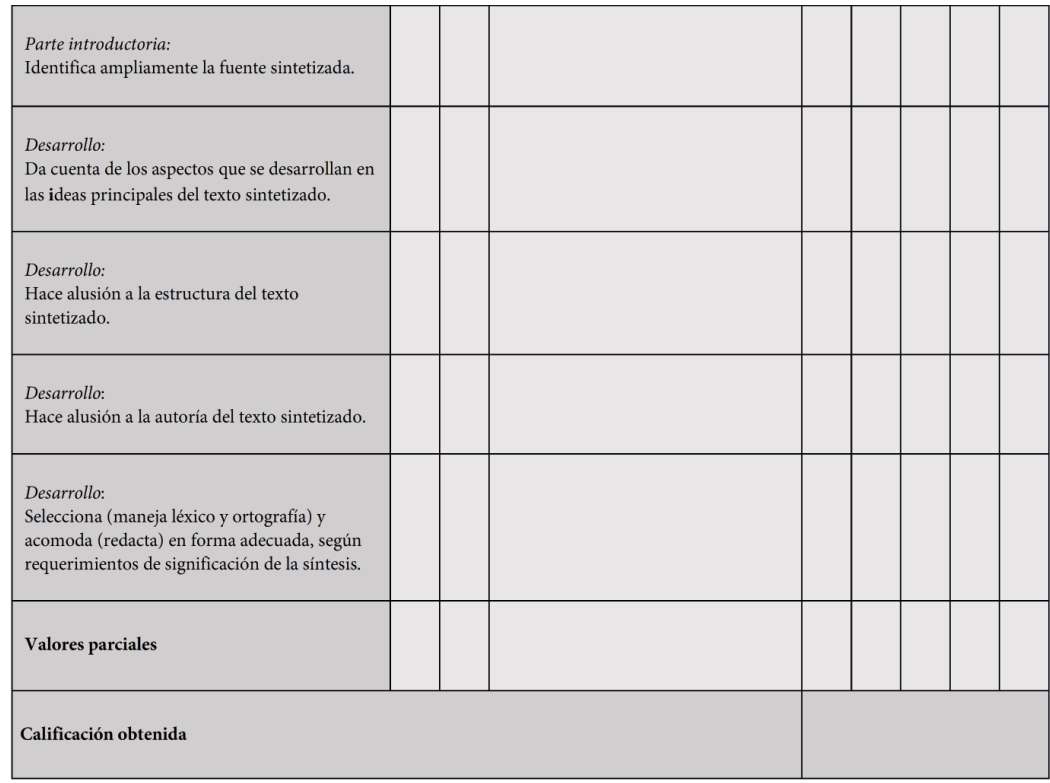

Elaboración propia.

TABLA NRO. 12. Equivalencias para la valoración de la síntesis

\begin{tabular}{|c|l|c|c|}
\hline Puntos & \multicolumn{1}{c|}{$\begin{array}{c}\text { Equivalencias } \\
\text { en términos cualitativos }\end{array}$} & $\begin{array}{c}\text { Escala } \\
\text { puntos obtenidos }\end{array}$ & $\begin{array}{c}\text { Nota } \\
\text { Obtenida }\end{array}$ \\
\hline 5 & Excelente: altamente adecuado. & 30 & 5.0 \\
\hline 4 & Bueno: adecuado (algunos errores u omisiones). & 24 & 3.0 \\
\hline 3 & Regular: inadecuado (muchos errores u omisiones). & 18 & 2.0 \\
\hline 2 & $\begin{array}{l}\text { Deficiente: no usa el recurso esperado o todos sus usos } \\
\text { son incorrectos. }\end{array}$ & 12 & 1.0 \\
\hline 1 & No sabe o no responde. & 6 & \\
\hline
\end{tabular}

Elaboración propia.

\subsection{Informe de lectura}

\subsubsection{Concepto}

El informe de lectura es uno de los productos de lectura más utilizados actualmente en la academia porque resulta práctico en su elaboración y ofrece muchas posibilidades evaluativas 
por parte del docente. Así lo advierten Agudelo et al. (2010) cuando se refieren a ellos: «son escritos que tienen como función dar testimonio de la comprensión de un texto leído, como cumplimiento de los niveles básicos de lectura: lectura literal, comprensión literal y comprensión interpretativa o inferencial» (p. 143).

Lopera $H$. por su parte, más que definirlo, resalta su importancia al señalar que:

Es un nuevo texto que surge del proceso de comprensión lectora aplicado por el estudiante. Ese texto que resulta de la lectura seria, metódica y orientada de un texto fuente adquiere independencia y se puede mostrar como una producción autónoma puesto que un tercer lector puede leerlo e interpretarlo sin necesidad de haber leído la obra fuente. Eso hace que la redacción de informes de lectura sea una actividad de notoria relevancia en el ámbito académico porque el estudiante estructura su pensamiento y adquiere elementos para asumir puntos de vista críticos y debidamente argumentados, y prepararse para la escritura de otras tipologías académicas como ensayos y monografías. [...] El informe debe guardar fidelidad a los conceptos y al lenguaje propio de la disciplina o la especialidad temática (s. f., p. 1).

\subsubsection{Procedimiento para su elaboración}

Hablando de la estructura del informe de lectura, Rincón (como se citó en Agudelo et al., 2014) considera:

De acuerdo con los objetivos que se pretendan alcanzar y el grado de exigencia [...] puede exponer, describir, explicar, analizar, interpretar o argumentar. En los cuatro primeros casos, predomina en el informe la estructura enunciativa; en los dos últimos, predomina la estructura argumentativa (p. 237). 
Estos autores acotan que, para evitar confusiones con otros tipos de trabajos, muchos prefieren desarrollar una estructura enunciativa, independientemente del lenguaje que se esté utilizando en el texto fuente del cual proviene el informe.

Su estructura comprende, según Agudelo et al. (2010) las partes que muestra la FigurA NRO. 13, las cuales ayudan a conducir el proceso de elaboración.

Figura NRo. 13. Partes del informe de lectura.

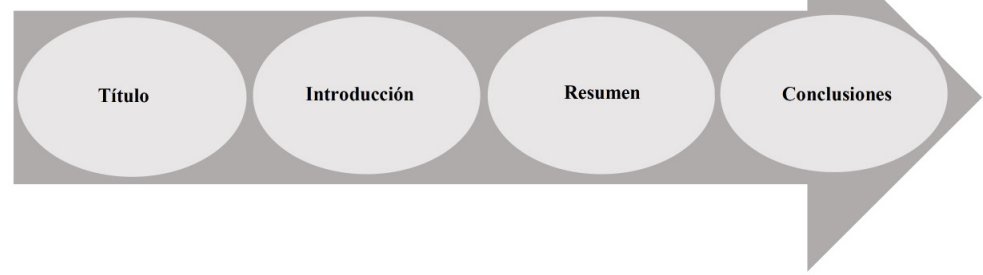

Tomada de Agudelo et al. (2010, p. 143).

\subsubsection{Título}

El título puede ser el mismo del texto fuente del cual se está construyendo el informe de lectura, siempre y cuando se ubique entre paréntesis el tipo de texto que le acompaña. También, puede ser creado por quien realiza el informe de acuerdo con la percepción que tenga del texto, en ese caso, no hay necesidad de hacer tal aclaración. Las demás partes se explican en los términos de Agudelo et al. (2010), teniendo en cuenta que el resumen, aquí señalado, es el cuerpo o desarrollo del informe delectura.

\subsubsection{Introducción}

Atiende a las especificaciones de toda introducción o presentación de un trabajo; sin embargo, para el informe de lectura hay que puntualizar qué podría contener algunas de sus partes: 
El qué: se identifica el texto leído o el evento (conferencia, exposición, foro, entre otros) sobre el cual se está haciendo el informe de lectura. Es recomendable ubicar aquí la temática, la obra o el autor (o conferencista) sobre un contexto y otros datos propios del texto, lo cual permite que, tanto quien realiza el informe como sus lectores, tengan mayores y mejores elementos para evaluar el documento final.

El para qué: se explicita la importancia que tiene el tema del cual trata el texto leído o encuentro.

A quiénes interesa: se especifica a quiénes les puede interesar el tema y se explican las razones de esa pertinencia para ese grupo o grupos señalados. Estas dos consideraciones constituyen la justificación de la realización del informe de lectura, la cual da pie a que el autor del informe plantee un objetivo al presentarlo.

Estructura: se dice cuáles son las partes que constituyen el texto fuente (bien sea este escrito, oral o audiovisual). Por ejemplo: capítulos, subtítulos, tomos o secciones, entre otras. En lo posible, se sintetiza cada una de estas partes.

Con Lopera (s.f.) se puede sintetizar lo explicado aquí para estructurar la introducción del informe de lectura: «incluye el objetivo del informe, la justificación y una breve descripción de las partes en que está estructurado elinforme» (p. 2).

\subsubsection{Cuerpo o desarrollo}

Se procede a realizar un resumen, basado en los capítulos, partes o secciones en que está dividido el texto fuente; esto, con el ánimo de no dejar por fuera contenidos sustanciales. Hay que recordar que el insumo para realizar resúmenes son las ideas principales. 


\subsubsection{Conclusiones}

Las conclusiones se presentan separadas por un doble espacio una de otra, y deben ser precisas y concisas. Son ideas producto de la reflexión sobre lo leído.

\subsubsection{Presentación (estructura formal)}

La portada es la puerta de entrada al trabajo, enuncia el título -ver sugerencias en subtítulo anterior, para su realización-y el autor. También, la institución a la cual se pertenece, así como la fecha y la ciudad. Estas partes han de ir distribuidas en la hoja, como se muestra en la TABLA NRO. 13.

TABLA NRo. 13. Presentación del informe de lectura: portada.

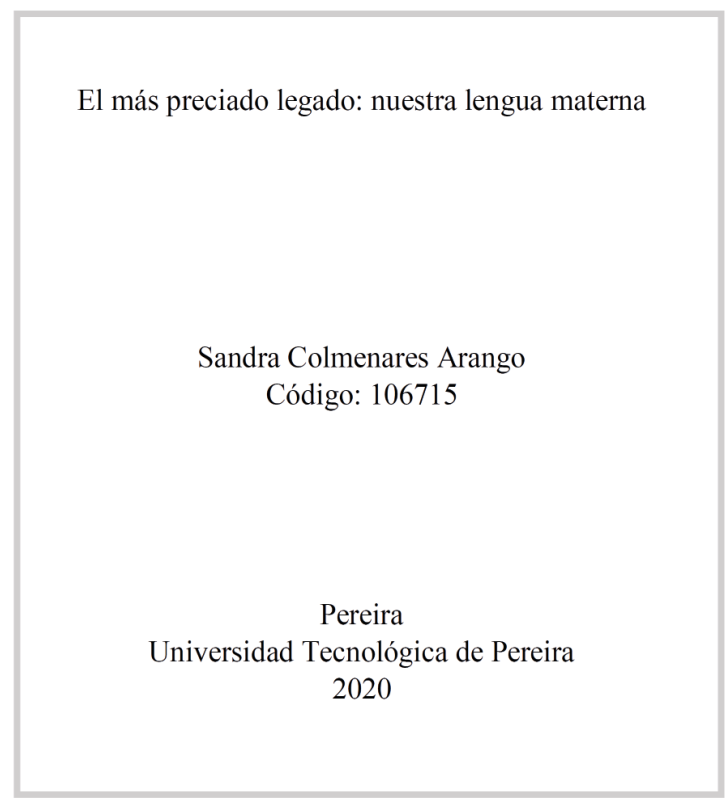

Elaboración propia.

Se continúa con el informe de lectura, se ubica el título (el que se plasmó en la parte superior de la portada);luego, se dispone, a manera de subtítulos principales, las demás partes del informe 
(introducción, cuerpo o desarrollo y conclusiones) con sus respectivos desarrollos. En este proceso, se debe aplicar la norma que se haya elegido (APA o Icontec). Esta distribución se puede apreciar en la TABLA NRO. 14.

TABLA NRO. 14. Presentación del informe de lectura: disposición de sus partes.

\begin{tabular}{|l|l|}
\hline \multicolumn{1}{|c|}{ Hoja l } & \\
\hline \multicolumn{1}{|c|}{$\begin{array}{l}\text { El más preciado legado: } \\
\text { nuestra lengua materna }\end{array}$} & $\begin{array}{l}\text { Si es corto, solo habría que decir, por ejemplo: en la primera } \\
\text { parte del texto, el autor... }\end{array}$ \\
\hline $\begin{array}{l}\text { Se procede a dar el resumen de cada uno de los apartados en los } \\
\text { cuales se divide el texto leído. }\end{array}$ \\
$\begin{array}{l}\text { Se escribe aquí la introducción según la información que esta } \\
\text { debe brindar. }\end{array}$ & $\begin{array}{l}\text { Si el texto está por subtítulos entonces se procede a ubicarlos o a } \\
\text { hacer alusión a ellos y dentro de cada uno dar el respectivo } \\
\text { informe a manera de resumen. }\end{array}$ \\
$\begin{array}{l}\text { Aquí el lector se entera de cuál texto va a dar cuenta el informe } \\
\text { de lectura, de su estructura, del objetivo que tiene quien realiza el } \\
\text { informe, de la importancia de dicho texto, entre otras } \\
\text { generalidades que pueden decirse. }\end{array}$ & $\begin{array}{l}\text { Conclusiones } \\
\text { Se concluye de acuerdo con el objetivo previsto en la } \\
\text { introducción, el cual lleva a presentar este informe de lectura. }\end{array}$ \\
$\begin{array}{l}\text { Cuerpo o desarrollo del informe } \\
\begin{array}{l}\text { Se procede a dar el resumen de cada uno de los apartados en los } \\
\text { cuales se divide el texto lédo. }\end{array}\end{array}$ & \\
\hline
\end{tabular}

Elaboración propia.

\subsubsection{Evaluación}

Lo dicho sobre el INFORME DE LECTURA se incluye en la rejilla que se presenta en la TABLA NRO. 15. Su valoración desde lo cualitativo permite registrar observaciones y sugerencias de ajuste; desde lo cuantitativo, constituye un instrumento para brindar una calificación (nota) que dé cuenta de la calidad del trabajo que se revisa. Para determinar si se califica uno u otro valor, pueden consultarse las respectivas equivalencias en la TABLA NRO. 16. 
TABLA NRO. 15. Rejilla para la valoración del informe de lectura.

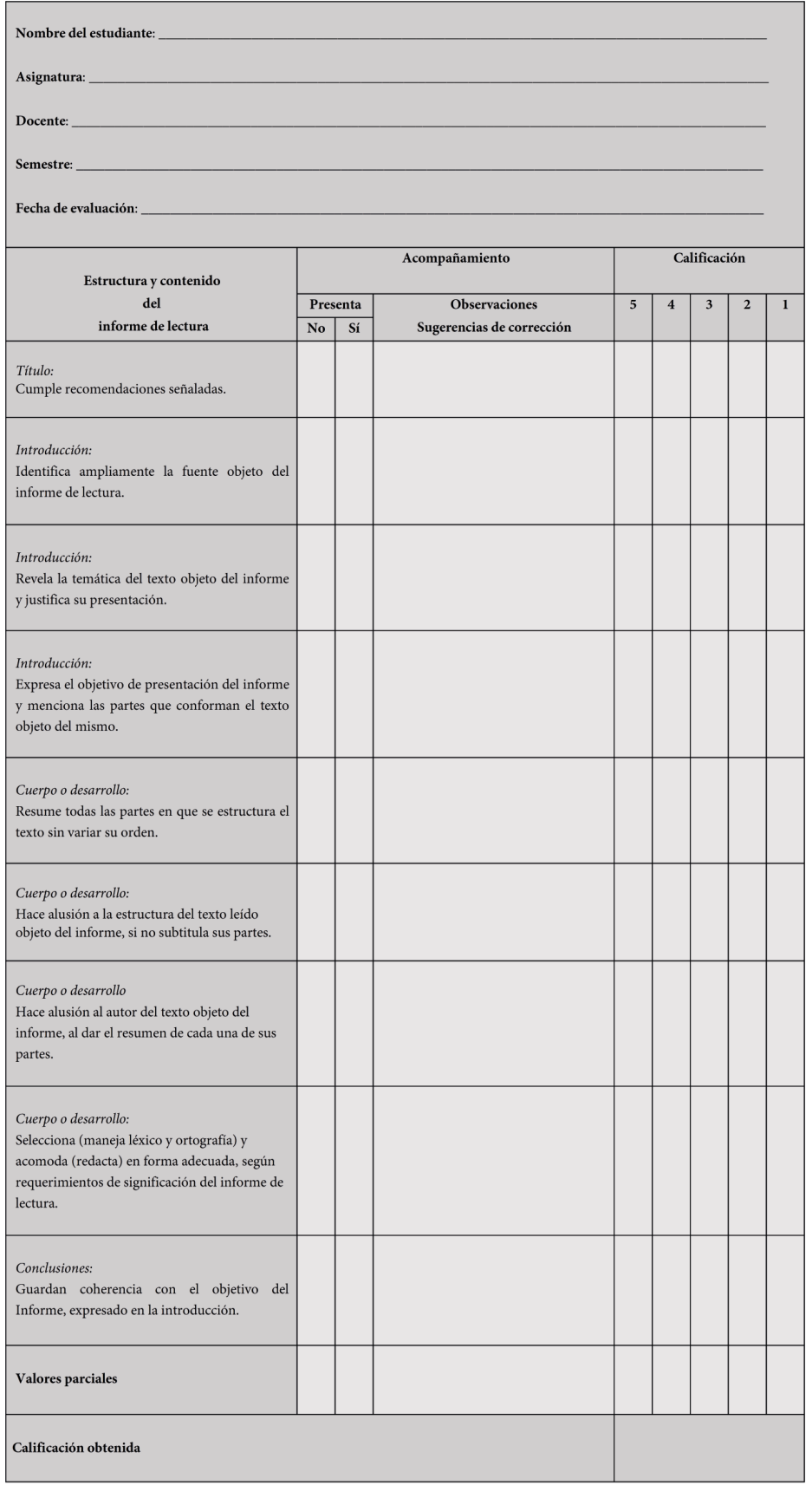

Elaboración propia. 
TABLA NRO. 16. Equivalencias para la valoración del informe de lectura.

\begin{tabular}{|c|l|c|c|}
\hline \multirow{2}{*}{ Puntos } & \multicolumn{1}{|c|}{$\begin{array}{c}\text { Equivalencias } \\
\text { en términos cualitativos }\end{array}$} & $\begin{array}{c}\text { Escala } \\
\text { puntos obtenidos }\end{array}$ & $\begin{array}{c}\text { Nota } \\
\text { Obtenida }\end{array}$ \\
\hline 5 & Excelente: altamente adecuado. & 45 & 5.0 \\
\hline 4 & Bueno: adecuado (algunos errores u omisiones). & 36 & 3.0 \\
\hline 3 & Regular: inadecuado (muchos errores u omisiones). & 27 & 2.0 \\
\hline 2 & $\begin{array}{l}\text { Deficiente: no usa el recurso esperado o todos sus usos } \\
\text { son incorrectos. }\end{array}$ & 18 & 9.0 \\
\hline 1 & No sabe o no responde. & 9 & 1.0 \\
\hline
\end{tabular}

Elaboración propia.

\subsection{Lectura comentada}

\subsubsection{Concepto}

En el ámbito académico dos acepciones se tienen con respecto a la lectura comentada: la primera asume que es un ejercicio de oralización del texto, guiado por el docente que busca que los alumnos valoren la lectura como fuente de enriquecimiento personal, de conocimiento del mundo. En esta concepción, este sirve para que los estudiantes se introduzcan paulatinamente en la interpretación y en el análisis de los textos. La segunda acepción (de mayor pertinencia dado el enfoque del presente libro) asume esta práctica como un producto escrito, resultante de un ejercicio de lectura.

Este resultado cumple una doble función: en principio, el mismo que efectúan los informes de lectura, es decir, dar testimonio de la comprensión de un texto leído como cumplimiento de los niveles básicos de lectura (lectura literal, comprensión literal y comprensión interpretativa o inferencial) para luego dar paso a la reflexión acerca de lo leído. Generalmente esta reflexión gira alrededor de la opinión del lector, sus conocimientos previos, sus experiencias y la aplicabilidad en el contexto en el cual se está haciendo la lectura, 
entre otras opciones. Ahora bien, este producto resultante puede también dar cumplimiento a un nivel avanzado de lectura: comprensión valorativa y crítica (Agudelo et al., 2010).

\subsubsection{Procedimiento para su elaboración}

La realización de una lectura comentada exige un proceso de comprensión (literal, interpretativa y crítica) de un documento, párrafo por párrafo y en su totalidad. En las primeras etapas del proceso de formación, esta tarea se hace bajo la guía del profesor quien, al mismo tiempo, realiza pausas con el objeto de profundizar en las partes relevantes del documento con sus reflexiones y comentarios. Paulatinamente, los estudiantes deben ir ganando la autonomía suficiente que les permita replicar la tarea sin el apoyo directo del docente.

El producto de este proceso conduce a la realización de un escrito que cumple una doble función:

- Dar testimonio de la comprensión del texto leído (lectura literal, comprensión literal y comprensión interpretativa).

- Reflexión sobre el texto leído: gira alrededor de la opinión del lector, su posición frente al texto, sus conocimientos previos, sus experiencias y la aplicabilidad en el contexto en el cual se está haciendo la lectura (comprensión valorativa y crítica).

La presentación final de la lectura comentada consta de tres partes: introducción, resumen comentado y conclusiones (cada una de estas partes ocupa una hoja independiente).La primera y la tercera parte tienen la misma estructura propuesta antes para el informe de lectura. La segunda parte está determinada por las características del resumen comentado, las cuales establece Agudelo et al. (2014) de la siguiente manera: 
Resumen comentado: Se realiza el resumen de cada una de las partes enunciadas al final de la introducción. Si se hace un resumen global sobre el texto o evento leído se corre el riesgo de omitir cuestiones (ideas principales o claves) importantes.

Después de cada resumen, a manera de último párrafo, se incluye entonces un comentario sobre el texto, el cual puede ir en todas o en algunas de las siguientes posibilidades para el lector, entre otras que este pueda tener al reflexionar acerca de un texto leído:

- Se incluyen otras teorías que reafirmen, complementen o refuten lo dicho.

- Se comenta sobre experiencias directas o indirectas que se han tenido con relación a lo dicho en el resumen.

- Se asume una posición crítica frente al texto.

- Se busca la aplicación que puede tener lo leído con respecto a un asunto o tema determinado.

- Se compara con otro lugar y otra época, diferentes a los del texto mismo, pudiendo ser el lugar y la época que vive el lector en ese momento (pp. 232-233).

\subsubsection{Presentación(estructura formal)}

La presentación final de la lectura comentada consta de tres partes, cada una en hoja independiente y titulada como tal: introducción, resumen comentado y conclusiones; esto con las mismas especificaciones dadas para el informe de lectura.

\subsubsection{Evaluación}

Lo dicho en las anteriores líneas sobre la LECTURA COMENTADA, se incluye en la rejilla que se presenta en la TABLA NRO. 17. Su valoración desde lo cualitativo busca ofrecer la 
oportunidad de registrar observaciones y sugerencias de ajuste; desde lo cuantitativo, constituye un instrumento para brindar una calificación (nota) que dé cuenta de la calidad del trabajo que se revisa. Para determinar si se califica uno u otro valor, pueden consultarse las respectivas equivalencias en la TABLA NRO. 18.

TABLA NRO. 17. Rejilla para la valoración de la lectura comentada.

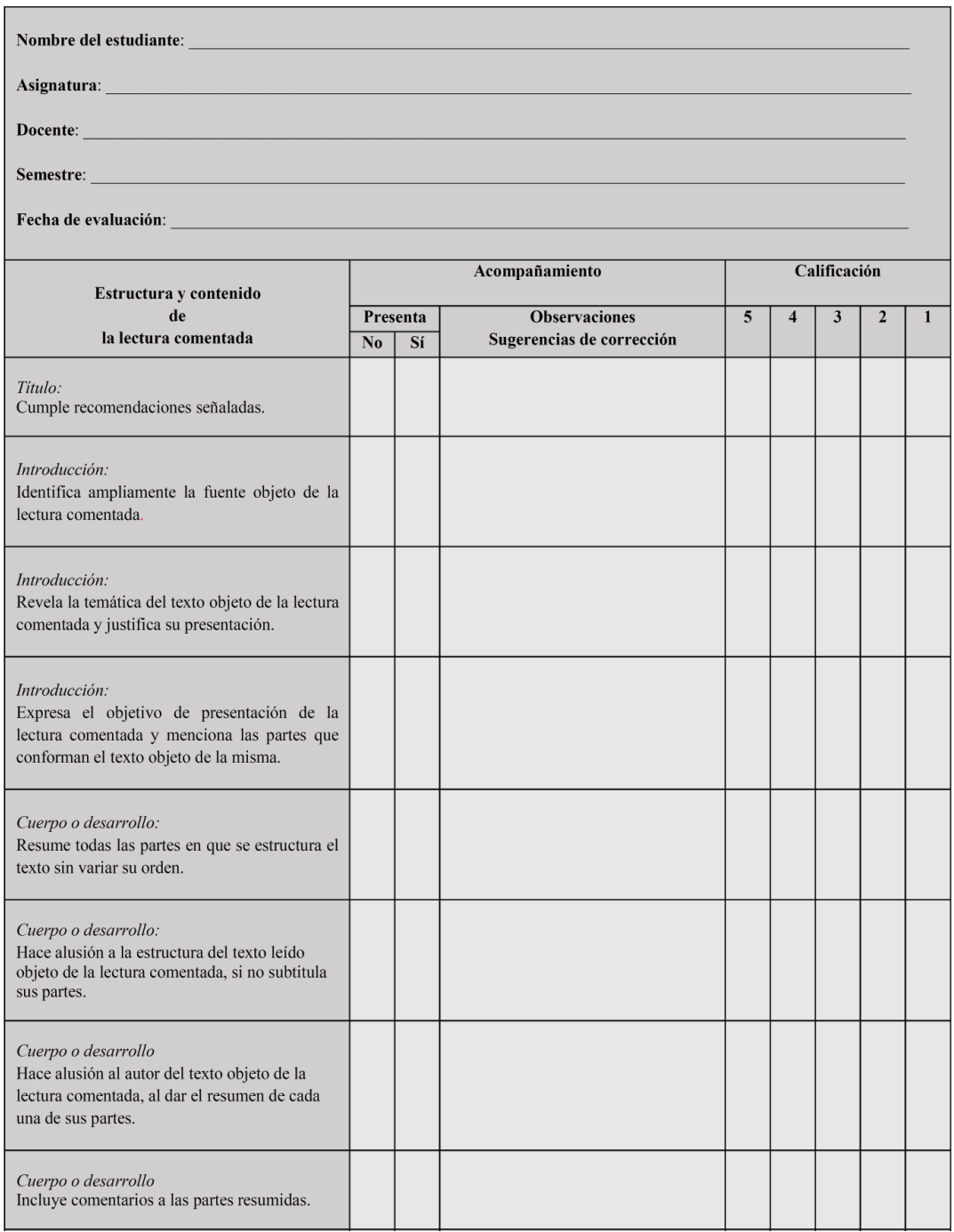




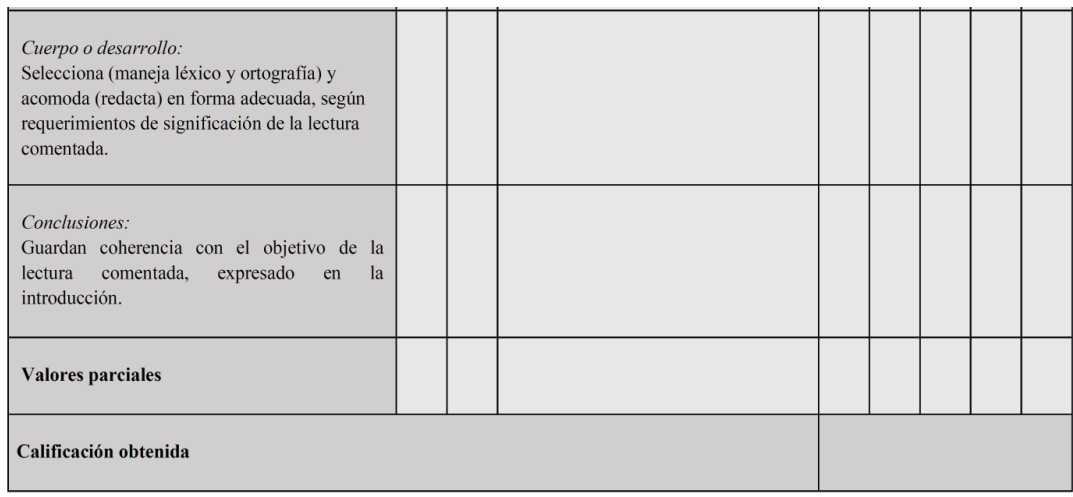

Elaboración propia.

TABLA NRO. 18. Equivalencias para la valoración de la lectura comentada.

\begin{tabular}{|c|l|c|c|}
\hline Puntos & \multicolumn{1}{|c|}{$\begin{array}{c}\text { Equivalencias } \\
\text { en términos cualitativos }\end{array}$} & $\begin{array}{c}\text { Escala } \\
\text { puntos obtenidos }\end{array}$ & $\begin{array}{c}\text { Nota } \\
\text { Obtenida }\end{array}$ \\
\hline 5 & Excelente: altamente adecuado. & 50 & 5.0 \\
\hline 4 & Bueno: adecuado (algunos errores u omisiones). & 40 & 3.0 \\
\hline 3 & Regular: inadecuado (muchos errores u omisiones). & 30 & 2.0 \\
\hline 2 & $\begin{array}{l}\text { Deficiente: no usa el recurso esperado o todos sus usos } \\
\text { son incorrectos. }\end{array}$ & 20 & 10 \\
\hline 1 & No sabe o no responde. & & 1.0 \\
\hline
\end{tabular}

Elaboración propia.

\subsection{Organizadores gráficos}

Los organizadores gráficos posibilitan la representación gráfica o simbólica de un contenido (ideas principales o conceptos) o de un texto (ya leído o por escribir). Este tipo de esquemas facilitan la planificación del estudio, la organización de las ideas alrededor de un tema - de cara a la construcción de un escrito- la planeación a la resolución de problemas o ejercicios, la toma de apuntes en forma organizada, la memorización de aspectos fundamentales sobre una materia o la interpretación de un texto leído. Por todo lo anterior, en la academia, con frecuencia, se recurre a la elaboración 
de organizadores gráficos como herramienta que facilita la estructuración de textos escritos u orales, o como mecanismo de apoyo en sus respectivos procesos de comprensión.

De cara a la producción de textos, la elaboración de este tipo de esquemas implica inicialmente determinar el tema o idea general del escrito; luego, a través de una técnica de generación de ideas (puede ser una lluvia de ideas), se hace un listado y se realiza una valoración, con el fin de agruparlas por categorías o subtemas que permitan el desarrollo de la idea general o del tema asumido en un comienzo. Al final, se diseña un esquema a partir de los grupos de ideas o conceptos definidos en el paso anterior. Esto se lleva a cabo, cuidando la integración de manera ordenada y jerárquica de los diferentes elementos que van a estructurar el texto.

Como herramienta de apoyo para la comprensión de lectura, la realización de un organizador gráfico requiere la aplicación de un procedimiento como el siguiente: en primer lugar, debe hacerse una lectura comprensiva del texto base (recurriendo al uso del subrayado o la toma de apuntes), con el propósito de identificar las ideas principales o los conceptos esenciales desarrollados. En segundo lugar, conviene analizar los subrayados o notas para organizar yjerarquizar los componentes destacados. En tercer lugar, se procede a plasmar el esquema ubicando la información (ideas principales, conceptos), de tal manera que su disposición en el formato evoque el texto fuente y permita reconstruir su contenido y su estructura.

\subsubsection{Cuadro sinóptico}

\subsubsection{Concepto}

El cuadro sinóptico es un organizador gráfico utilizado para representar visualmente la estructura lógica de distintos tipos de material, especialmente de elementos educativos. Este tipo de esquema, así como el mapa conceptual, proporciona 
una estructura coherente de una temática y sus múltiples relaciones. Un cuadro sinóptico puede emplearse en diversos ámbitos para tareas como la estructuración de contenidos que serán expresados de forma oral -en conferencias o clases magistrales-, la síntesis de información sobre un tema o un texto $y$, dado su carácter organizado, como herramienta de estudio para facilitar la memorización de información.

\subsubsection{Procedimiento para su elaboración}

Para elaborar un cuadro sinóptico que sintetice un texto es necesario:

- Realizar una lectura atenta que permita identificar los conceptos y las ideas esenciales del documento.

- Agrupar los conceptos de acuerdo con las conexiones y las relaciones temáticas que hay entre ellas.

- Jerarquizar dichos conceptos para que -en el cuadrose pueda desplegar la información de lo general a lo particular.

- Diseñar la presentación gráfica recurriendo a los modelos mencionados anteriormente, conservando el orden y la claridad. Esto garantiza realmente la representación del contenido del texto.

- Revisar el esquema, puliendo aquellos detalles que puedan resultar disonantes o dificultosos para la comprensión del tema allí representado.

\subsubsection{Presentación formal}

Los cuadros sinópticos pueden adoptar dos formas de presentación: la primera (quizá la más usual) integra las ideas centrales del texto a través de llaves y viñetas; la segunda, a través de tablas con columnas y filas. 
En el primer caso, el tema o idea general del texto se explicita a la izquierda del esquema y la información que se deriva del mismo se va desplegando organizadamente hacia la derecha, procurando conservar siempre las relaciones entre las partes. Un ejemplo de esta forma de representación puede verse en la FIGURA NRO. 14.

En el segundo caso, la tabla debe estar encabezada con el tema o idea general deltexto esquematizado. En la fila superior aparecen definidas las variables o características que permiten estructurar la información; y en la columna de la izquierda se discriminan los conceptos y subtemas principales, como lo ilustra la TABLA NRO. 19.

FigURA NRO. 14. El cuadro sinóptico, una forma de representación.
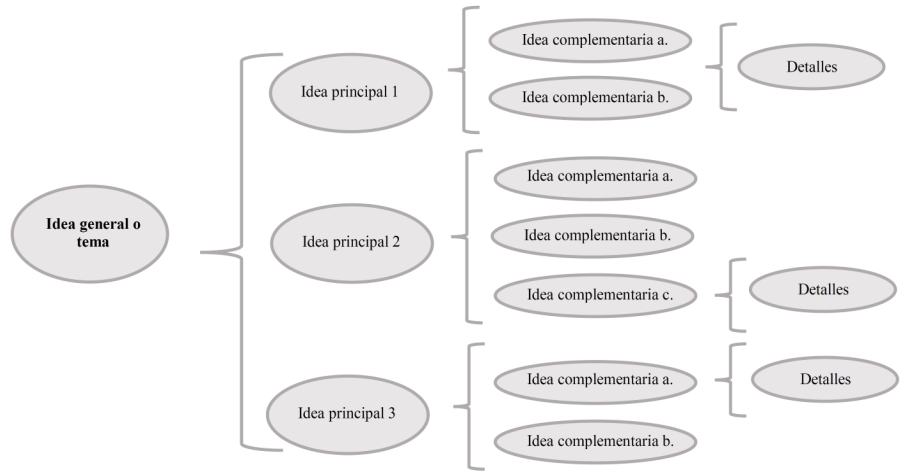

Tomada de: Agudelo et al. (2014, p. 37).

TABLA NRO. 19. El cuadro sinóptico, otra forma de representación.

\begin{tabular}{|c|l|l|}
\hline \multicolumn{3}{|c|}{ AUTORES LITERATURA COLOMBIANA } \\
\hline Géneros / época & \multicolumn{1}{|c|}{ Lírica } & \multicolumn{1}{|c|}{ Narrativa } \\
\hline Siglo XIX & $\begin{array}{l}\text { José Eusebio Caro } \\
\text { Julio Arboleda } \\
\text { Gregorio Gutiérrez González } \\
\text { Rafael Pombo }\end{array}$ & $\begin{array}{l}\text { Soledad Acosta de Samper } \\
\text { Eustaquio Palacios } \\
\text { Felipe Pérez } \\
\text { Jorge Isaacs }\end{array}$ \\
\hline \multirow{2}{*}{ Siglo XX Primera mitad } & $\begin{array}{l}\text { Jorge Artel } \\
\text { Luis Vidales } \\
\text { Jorge Zalamea } \\
\text { León de Greiff } \\
\text { Eduardo Carranza } \\
\text { Jorge Rojas }\end{array}$ & $\begin{array}{l}\text { Tomás Carrasquilla } \\
\text { José Eustasio Rivera } \\
\text { Bernardo Arias Trujillo } \\
\text { Eduardo Zalamea Borda }\end{array}$ \\
\hline
\end{tabular}

Tomada de: Agudelo et al. (2014, p. 38). 


\subsubsection{Evaluación}

Lo dicho en las anteriores líneas sobre CUADRO SINÓPTICO se incluye en la rejilla que se presenta en la TABLA NRO. 20. Su valoración desde lo cualitativo busca ofrecer la oportunidad de registrar observaciones y sugerencias de ajuste; desde lo cuantitativo, constituye un instrumento para brindar una calificación (nota) que dé cuenta de la calidad del trabajo que se revisa. Para determinar si se califica uno u otro valor, pueden consultarse las respectivas equivalencias en la TABLA NRO. 21.

TABLA NRO. 20. Rejilla para la valoración del cuadro sinóptico.

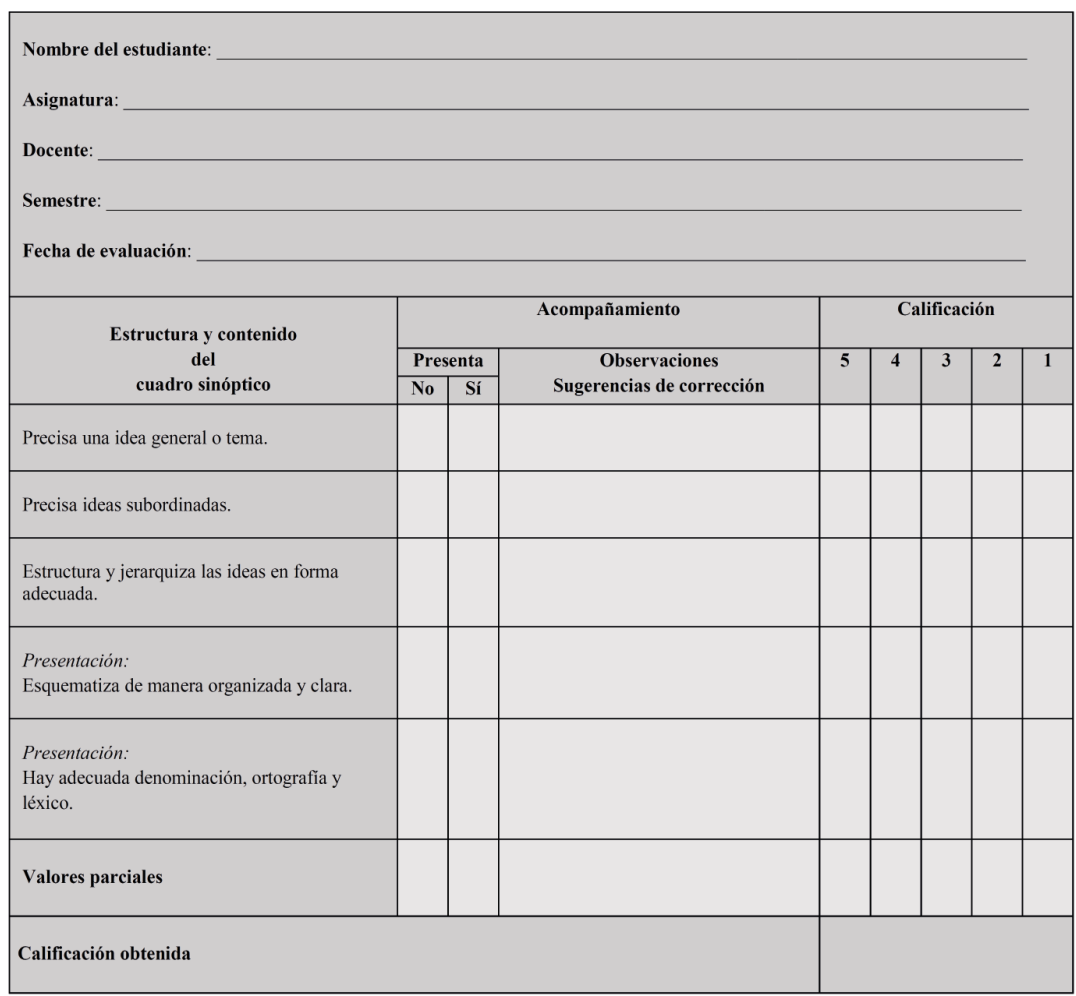

Elaboración propia. 
TABLA NRO. 21. Equivalencias para la valoración del cuadro sinóptico.

\begin{tabular}{|c|l|c|c|}
\hline Puntos & \multicolumn{1}{|c|}{$\begin{array}{c}\text { Equivalencias } \\
\text { en términos cualitativos }\end{array}$} & $\begin{array}{c}\text { Escala } \\
\text { puntos obtenidos }\end{array}$ & $\begin{array}{c}\text { Nota } \\
\text { Obtenida }\end{array}$ \\
\hline 5 & Excelente: altamente adecuado. & 25 & 5.0 \\
\hline 4 & Bueno: adecuado (algunos errores u omisiones). & 20 & 3.0 \\
\hline 3 & Regular: inadecuado (muchos errores u omisiones). & 15 & 2.0 \\
\hline 2 & $\begin{array}{l}\text { Deficiente: no usa el recurso esperado o todos sus usos } \\
\text { son incorrectos. }\end{array}$ & 10 & 1.0 \\
\hline 1 & No sabe o no responde. & 5 & \\
\hline
\end{tabular}

Elaboración propia.

\subsubsection{Mapa mental}

\subsubsection{Concepto}

Los mapas mentales son, como otros tipos de esquemas, herramientas mediante las cuales se esquematiza un conjunto de ideas y se establecen relaciones entre palabras, frases, oraciones, símbolos e imágenes. Todo ello con el propósito de facilitar la memorización o la organización de volúmenes de información que se requieren de cara al aprendizaje. Su particularidad es que el mapa mental -al integrar diversos mecanismos de representación como palabras, frases, imágenes, símbolos y colores- activa la participación de distintas funciones cognitivas de ambos hemisferios cerebrales. Esto permite incrementar los niveles de asociación de ideas.

\subsubsection{Procedimiento para su elaboración}

Para elaborar un mapa mental es necesario realizar una serie de actividades. Las principales son: determinar el tema; establecer los subtemas en orden jerárquico progresivo (de mayor a menor generalidad); y trazar las ramas y sub-ramas, teniendo en cuenta que en estas primeras van los aspectos centrales y en las segundas los temas específicos. En este tipo de esquemas, tanto el tema central como las sub-ramas, 
pueden relacionarse con palabras, frases, oraciones, símbolos e imágenes. Además, han de tenerse en cuenta las siguientes recomendaciones:

- Emplear un mínimo de palabras para no recargar de texto el mapa mental.

- Seleccionar las palabras que resulten clave para lograr la síntesis del texto.

- Ubicar en el centro de la hoja la expresión que presente el tema.

- Distribuir en la hoja los elementos, de tal manera que el efecto visual que se registre al final resulte agradable e impactante con el propósito de facilitar la comprensión.

- Utilizar el espacio necesario y suficiente para esquematizar el contenido del texto fuente.

- Usar colores, imágenes o símbolos que contribuyan a diferenciar, resaltar o complementar las palabras clave o las relaciones que se establezcan.

Un ejemplo que recoge las recomendaciones anteriores para la realización de un mapa mental se puede observar en la FIgURA NRO. 15.

\subsubsection{Presentación formal}

Se recomienda, en el caso de este tipo de organizadores gráficos, tener en cuenta algunas consideraciones con respecto a su presentación. En primer lugar, es necesario que el tema o aspecto central mapeado se ubique en el centro del formato, y se represente con palabras y una imagen (este elemento, por su ubicación, colorido y fuerza expresiva, debe llamar la atención del lector del mapa mental). Conservando una estructura 
radial, se disponen luego los elementos derivados del anterior $y$, a partir de ellos, se despliegan los nodos con la información esencial.

Por su naturaleza, se recomienda combinar palabras clave (en lo posible nunca enunciados extensos o complejos), imágenes, líneas y colores como mecanismos para representar la información.

Figura NRO. 15. Ejemplo de mapa mental.

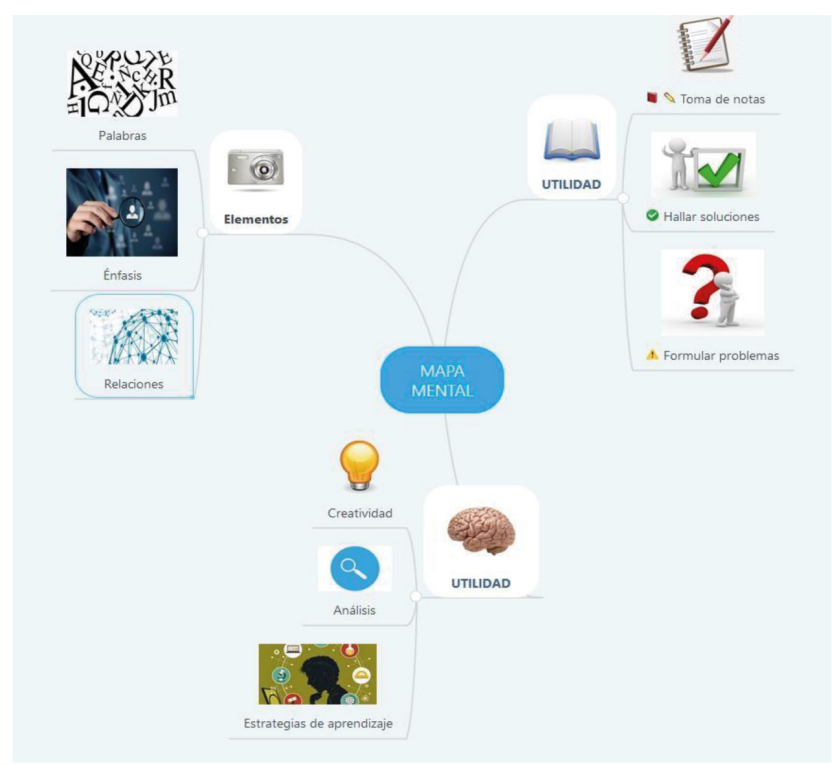

Basado en Agudelo et al. (2014, p. 39).

\subsubsection{Evaluación}

Lo dicho en las anteriores líneas sobre el MAPA MENTAL se incluye en la rejilla que se presenta en la TABLA NRO. 22. Su valoración desde lo cualitativo busca ofrecer la oportunidad de registrar observaciones y sugerencias de ajuste; desde lo cuantitativo, constituye un instrumento para brindar una calificación (nota) que dé cuenta de la calidad del trabajo que se revisa. Para determinar si se califica uno u otro valor, pueden consultarse las respectivas equivalencias en la TABLA NRO. 23. 
TABLA NRO. 22. Rejilla para la valoración del mapa mental.

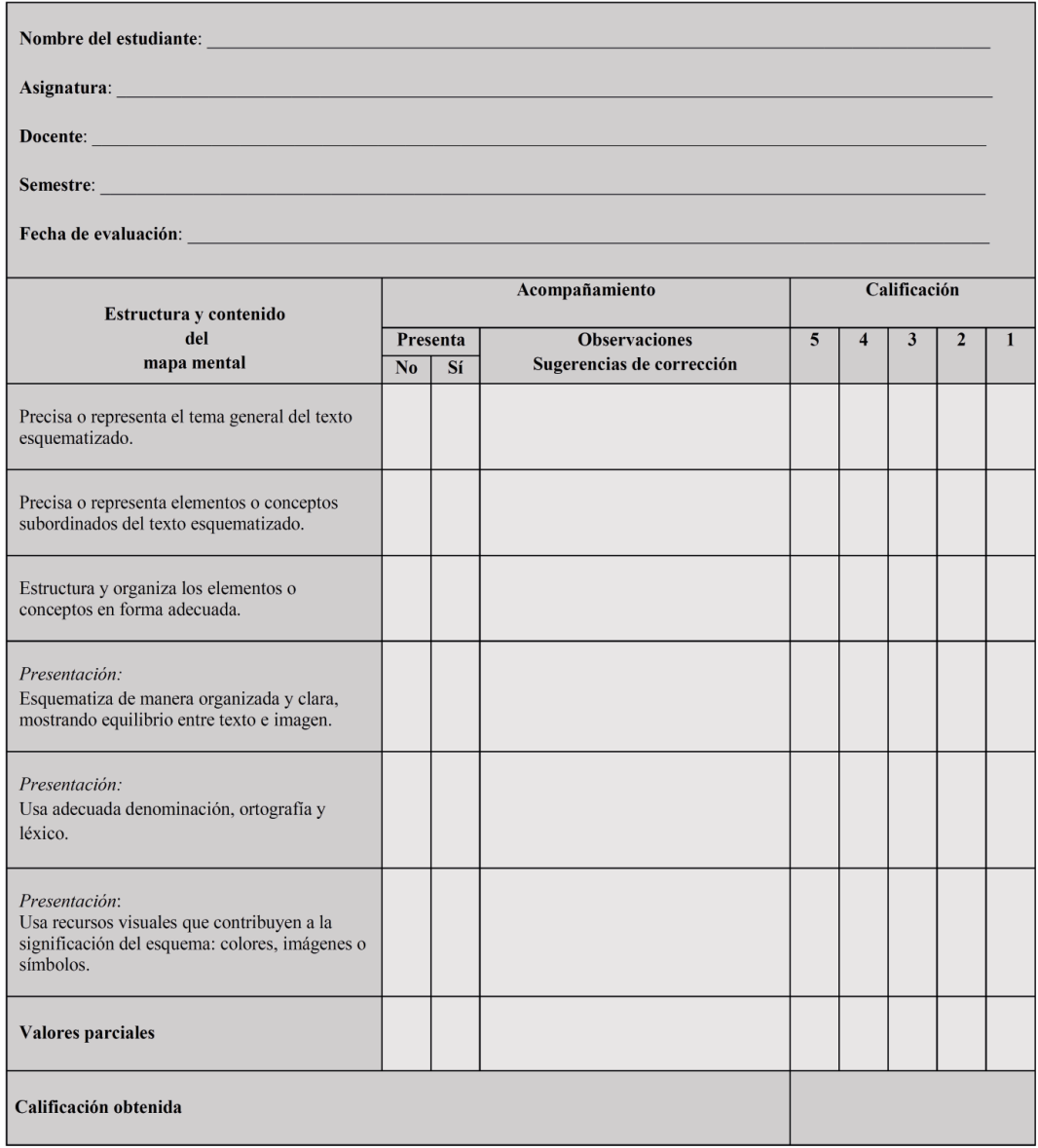

Elaboración propia.

TABLA NRO. 23. Equivalencias para la valoración del mapa mental.

\begin{tabular}{|c|l|c|c|}
\hline Puntos & \multicolumn{1}{|c|}{$\begin{array}{c}\text { Equivalencias } \\
\text { en términos cualitativos }\end{array}$} & $\begin{array}{c}\text { Escala } \\
\text { puntos obtenidos }\end{array}$ & $\begin{array}{c}\text { Nota } \\
\text { Obtenida }\end{array}$ \\
\hline 5 & Excelente: altamente adecuado. & 30 & 5.0 \\
\hline 4 & Bueno: adecuado (algunos errores u omisiones). & 24 & 4.0 \\
\hline 3 & Regular: inadecuado (muchos errores u omisiones). & 18 & 3.0 \\
\hline 2 & $\begin{array}{l}\text { Deficiente: no usa el recurso esperado o todos sus usos } \\
\text { son incorrectos. }\end{array}$ & 12 & 2.0 \\
\hline 1 & No sabe o no responde. & 6 & 1.0 \\
\hline
\end{tabular}

Elaboración propia. 


\subsubsection{Mapa conceptual}

\subsubsection{Concepto}

El mapa conceptual es un organizador gráfico, centrado en la representación sintética de un tema y sus derivaciones a través de la esquematización de los conceptos y relaciones que lo integran; se compone, según Agudelo et al. (2014), de los siguientes elementos: conceptos, enlaces, palabras de enlace, relaciones cruzadas yproposiciones.

Un concepto se entiende como «una palabra o término que manifiesta una regularidad en los hechos, acontecimientos, objetos, ideas, cualidades, animales» (Maya y Díaz, 2002, p. 49). La etiqueta, en este sentido, se representa a través de una expresión que se escribe en mayúscula sostenida y aparece encerrada en un óvalo o en un recuadro. En el caso de querer trabajar un tipo de texto académico, quedaría como se aprecia en la Figura NRO. 16.

FIGURA NRO. 16. Mapa conceptual: representación de un concepto.

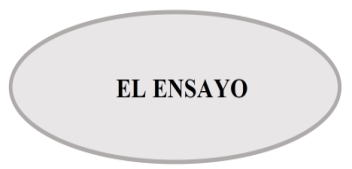

Tomada de Agudelo et al. (2014, p. 34).

Los enlaces se representan a través de líneas que integran o unen conceptos relacionados entre sí. Los enlaces aparecen siempre acompañados de las palabras de enlace, las cuales operan como elementos verbales que determinan el tipo de relación que se establece entre los dos conceptos relacionados, como se ejemplifica en la Figura NRO. 17.

Una proposición consiste en la relación que integra varios conceptos, relacionados entre sí. Dicha relación expresa una idea completa, como aparece en el ejemplo de la Figura NRO. 18 . 
Las relaciones cruzadas indican la vinculación directa que se establece entre dos conceptos los cuales pertenecen a proposiciones diferentes y se representan a través de una flecha. Esto se ilustra en la FigURA NRO. 19.

FIGURA NRO. 17. Mapa conceptual: enlace y palabra de enlace.

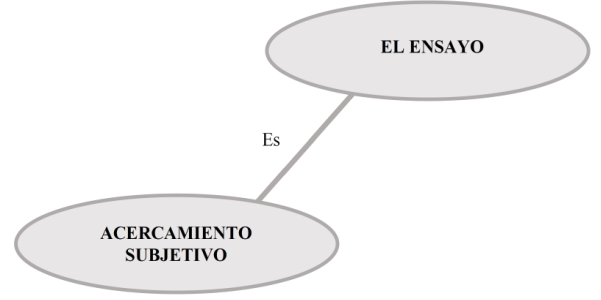

Tomada de Agudelo et al. (2014, p. 34).

FIGURA NRO. 18. Mapa conceptual: representación de una proposición.

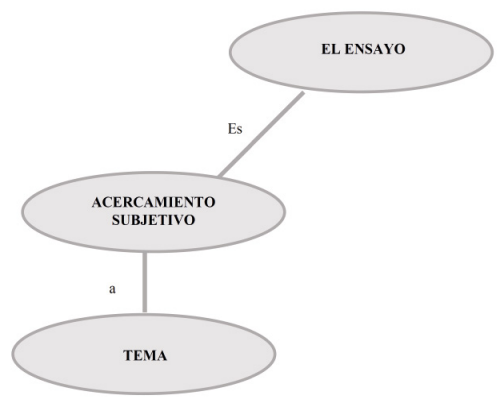

Tomada de Agudelo et al. (2014, p. 34).

En un mapa conceptual correctamente elaborado deben cuidarse las siguientes características en calidad de criterios propios de este organizador gráfico, a saber: la capacidad de síntesis, el orden, la jerarquización yel impacto visual. La síntesis garantiza que la información contenida en el mapa conceptual resulte esencial; esta exige además que, en el mapa conceptual, los conceptos no aparezcan repetidos. El orden indica que la distribución de los conceptos en el formato respete la lógica propia del tema mapeado. La jerarquización se desprende de lograr que, en el mapa conceptual, la relación entre los conceptos y la posición que ocupan unos con respecto a los otros permita 
descubrir el nivel de relación o de importancia y generalidad que hay entre ellos. El impacto visual depende de la capacidad de representar con claridad y precisión la estructura del texto del cual se origina o la estructura del texto que se pretende escribir. La Figura NRo. 20 ilustra lo anterior a través de un ejemplo.

FIGURA NRO. 19. Mapa conceptual: representación de una relación cruzada.

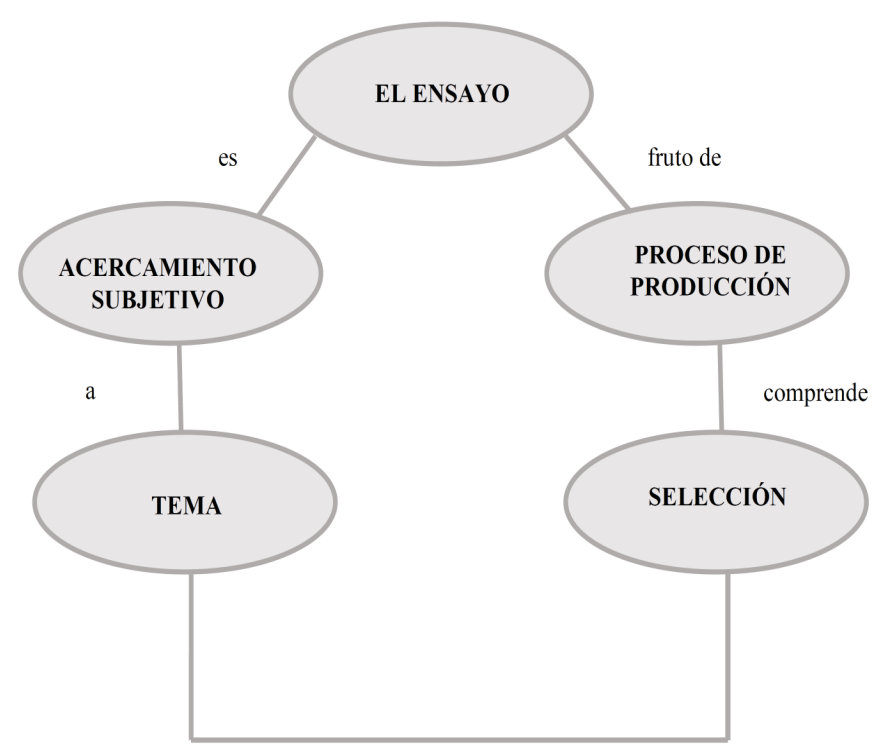

Tomada de Agudelo et al. (2014, p. 35).

\subsubsection{Procedimiento para su elaboración}

Un mapa conceptual suele realizarse para dar cuenta del contenido de un texto. Sin embargo, en otras ocasiones acudimos a este organizador gráfico como herramienta para hablar acerca de un tema, sea en forma oral o en forma escrita. Para ambas circunstancias se pueden encontrar recomendaciones en la TABLA NRO. 24. 
FIGURA NRO. 20. Ejemplo de un mapa conceptual.

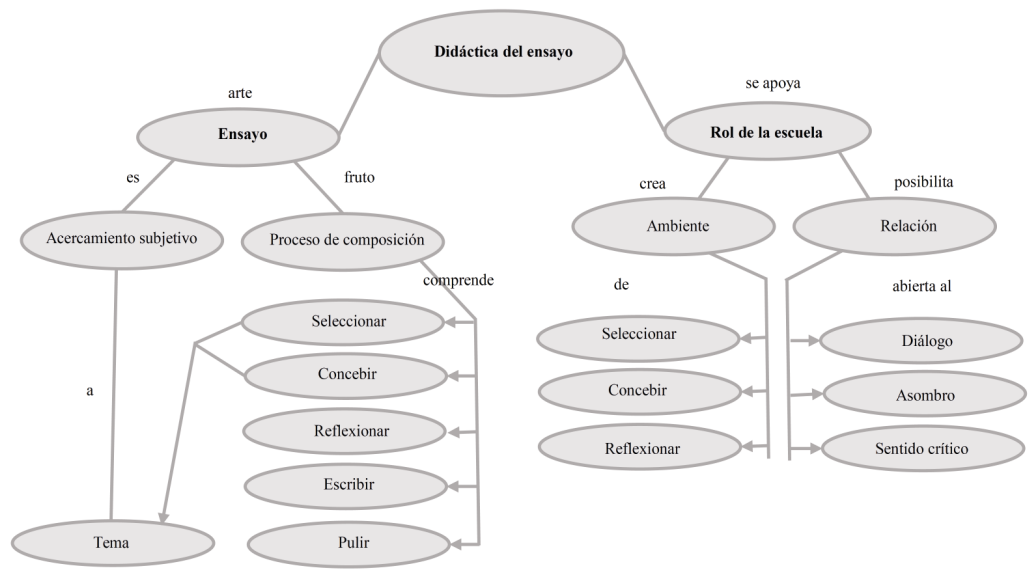

Tomada de Agudelo et al. (2014, p. 36).

\subsubsection{Presentación formal}

Este tipo de organizador gráfico requiere un alto nivel de estructuración.Esta misma obedece a una serie de convenciones que facilitan su elaboración y también su lectura. Dentro de estas sedestacan:

- En la parte superior del esquema debe aparecer el concepto central o abarcador.

- En sentido vertical se despliegan los conceptos derivados con el fin de cuidar que los conceptos de un mismo nivel estén a la misma altura en el formato.

- Los conceptos deben escribirse con mayúscula sostenida y deben aparecer encerrados en óvalos. Un mismo concepto no debe aparecer en varios óvalos o en varios puntos del mapa conceptual.

- Las palabras de enlace se escriben en minúscula y no se encierran. Las palabras de enlace o conectores pueden repetirse. 
- Las relaciones entre dos conceptos se establecen a través de líneas sencillas.

- Las relaciones cruzadas se representan a través de flechas.

TABla NRo. 24. Procedimiento para la elaboración del mapa conceptual.

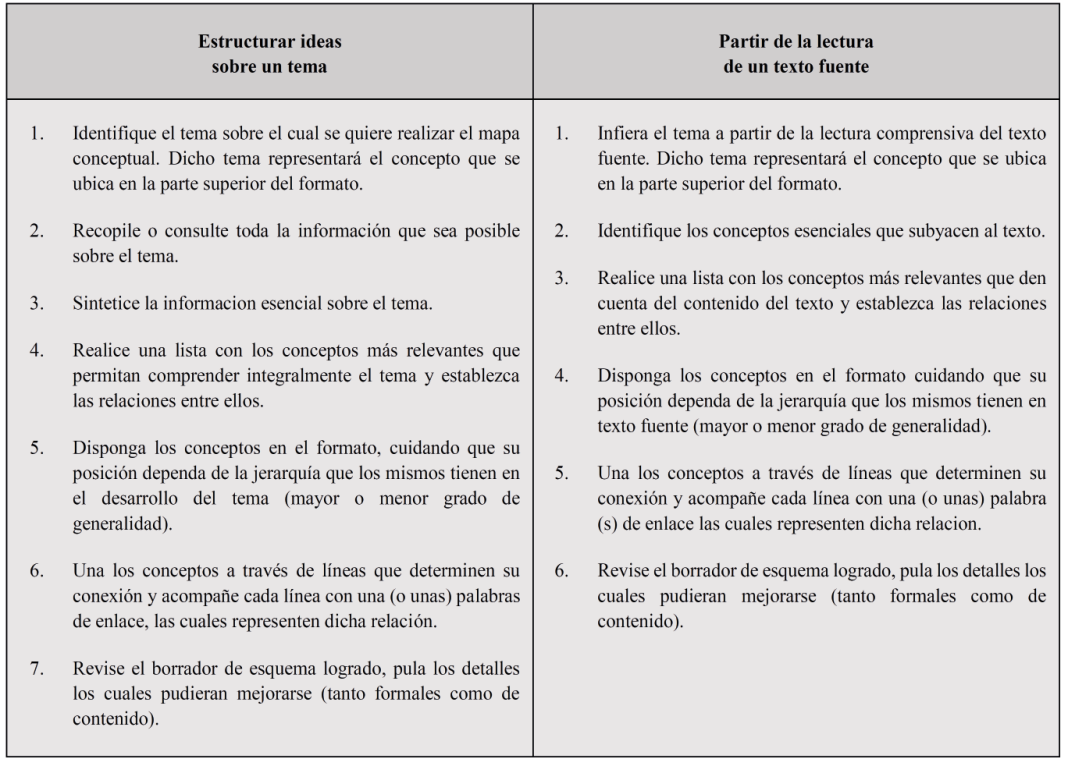

Elaboración propia.

\subsubsection{Evaluación}

Lo dicho en las anteriores líneas sobre el MAPA CONCEPTUAL se incluye en la rejilla que se presenta en la TABLA NRO. 25. Su valoración desde lo cualitativo busca ofrecer la oportunidad de registrar observaciones y sugerencias de ajuste; desde lo cuantitativo, constituye un instrumento para brindar una calificación (nota) que dé cuenta de la calidad del trabajo que se revisa. Para determinar si se califica uno u otro valor, pueden consultarse las respectivas equivalencias en la TABLA NRO. 26. 
TABLA NRO. 25. Rejilla para la valoración del mapa conceptual.

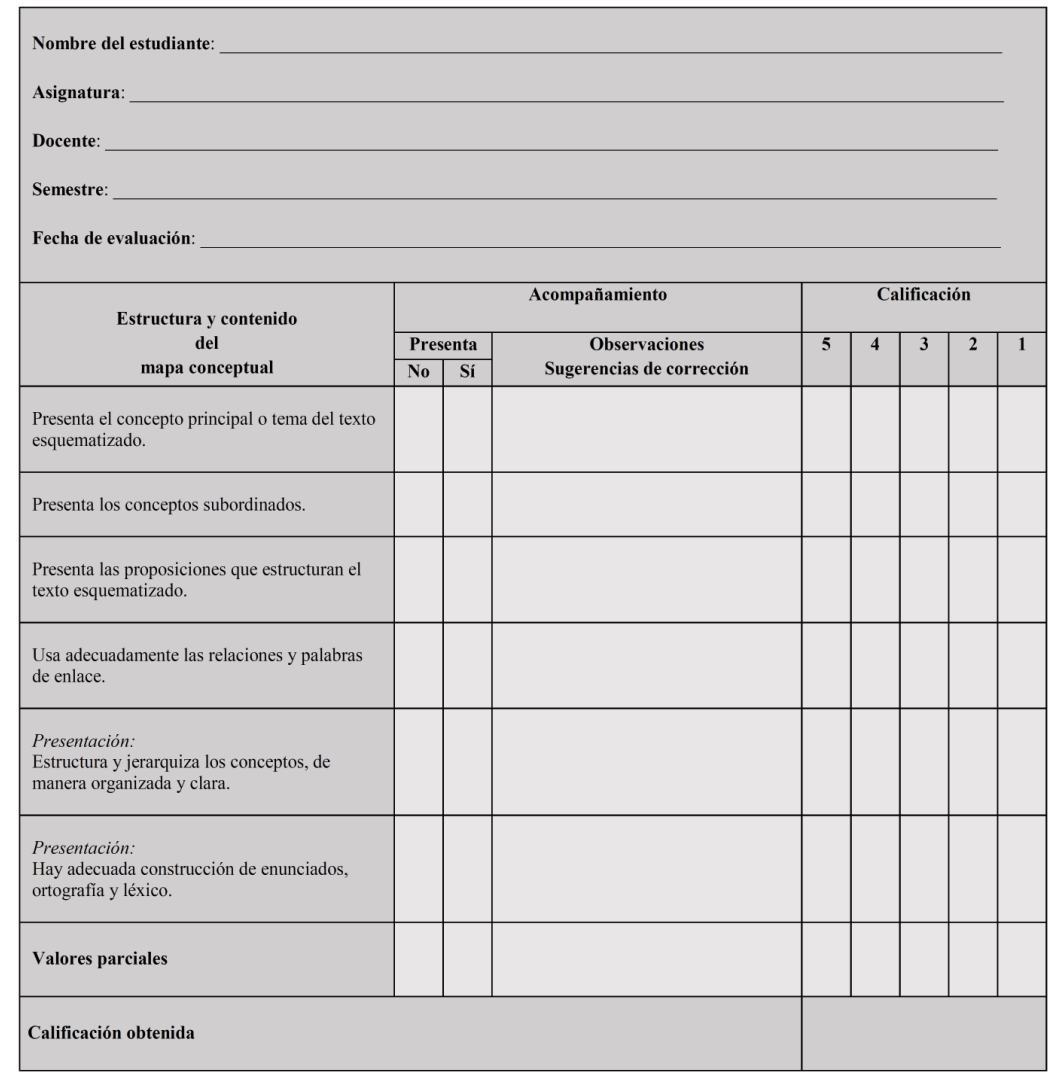

Elaboración propia.

TABLA NRO. 26. Equivalencias para la valoración del mapa conceptual.

\begin{tabular}{|c|c|c|c|}
\hline Puntos & $\begin{array}{l}\text { Equivalencias } \\
\text { en términos cualitativos }\end{array}$ & $\begin{array}{l}\text { Escala } \\
\text { puntos obtenidos }\end{array}$ & $\begin{array}{c}\text { Nota } \\
\text { obtenida }\end{array}$ \\
\hline 5 & Excelente: altamente adecuado. & 30 & 5.0 \\
\hline 4 & Bueno: adecuado (algunos errores u omisiones. & 24 & 4.0 \\
\hline 3 & Regular: inadecuado (muchos errores u omisiones). & 18 & 3.0 \\
\hline 2 & $\begin{array}{l}\text { Deficiente: no usa el recurso esperado o todos sus usos } \\
\text { son incorrectos. }\end{array}$ & 12 & 2.0 \\
\hline 1 & No sabe o no responde. & 6 & 1.0 \\
\hline
\end{tabular}

Elaboración propia. 


\subsection{Reseña critica}

\subsubsection{Concepto}

Es un texto expositivo-argumentativo que implica, en primer lugar, haber comprendido muybien el producto cultural reseñado (obra literaria, cuento, película, pintura, ensayo, entre otros) para poder resumir lo esencial de su contenido; además, es necesario que quien realice la reseña esté en condiciones de emitir opiniones y juicios de valor fundamentados acerca del texto leído. En la reseña crítica se hace un recuento del contenido de una obra, de sus ideas esenciales y de sus aspectos interesantes. Paralelamente, se hace una valoración crítica del mismo. El autor de la reseña debe aclarar que la valoración de la obra corresponde a su posición. De este modo, deja al lector en libertad para que forme su propia opinión.

Una buena reseña crítica requiere el empleo de brevedad y precisión en el estilo; exige que el autor realice un análisis riguroso de la obra por reseñar y dé cuenta de un conocimiento profundo del contexto en que esta se produce. Es característico de la reseña crítica, además, el carácter argumentativo con el cual el reseñista apoya la valoración que hace de la obra examinada.

\subsubsection{Procedimiento para su elaboración}

Se realiza una reseña teniendo en cuenta los siguientes elementos, señalados por Agudelo et al. (2014):

\subsubsection{Título}

Puede coincidir con el de la obra que se está reseñando o puede ser creado por el reseñista a propósito del aspecto central el cual quiere destacar en su valoración. 


\subsubsection{Identificación general del texto o evento por reseñar}

Algunos autores presentan esta información a través de una ficha técnica, otros prefieren redactar un párrafo que contiene tales datos.

\subsubsection{Contextualización de la obra}

En al menos un párrafo se busca ubicar la obra y el autor en la época, el género, la escuela o la corriente a la cual pertenece. En otros casos, se aprovecha esta parte para comparar la obra con otras de su tipo.

\subsubsection{Síntesis del contenido}

Se identifican los elementos, los aspectos o las características destacadas de la obra reseñada y se hace una síntesis de su contenido, sin pretender ser exhaustivos.

\subsubsection{Comentario crítico}

El reseñista ofrece sus puntos de vista valorativos con respecto a la obra, cuidándose de señalar tanto los aspectos que pudieran resultar positivos, como aquellos que considera negativos.

\subsubsection{Presentación (estructura formal)}

En cuanto a la presentación de la reseña crítica se recomienda ubicar el título en la primera hoja y centrado. En caso de usarse el mismo título de la fuente que se va a reseñar, se escribe entre paréntesis el tipo de texto (reseña crítica) luego, se escribe una prosa seguida para cumplir con las partes ya mencionadas en el procedimiento de elaboración. Estas conforman la estructura de este tipo de texto, de la siguiente manera: 


\subsubsection{Parte introductoria}

Incluye la identificación general del texto sintetizado y la contextualización; de acuerdo con la explicación dada en el apartado anterior (numeral 2.7.2).

\subsubsection{Contenido}

Comprende la síntesis del contenido y el comentario crítico, de acuerdo con la explicación dada en el numeral 2.7.2.

\subsubsection{Evaluación}

Lo dicho en las anteriores líneas sobre la RESEÑA CRÍTICA se incluye en la rejilla que se presenta en la TABLA NRO. 27. Su valoración desde lo cualitativo busca ofrecer la oportunidad de registrar observaciones y sugerencias de ajuste; desde lo cuantitativo, constituye un instrumento para brindar una calificación (nota) que dé cuenta de la calidad del trabajo que se revisa. Para determinar si se califica uno u otro valor, pueden consultarse las respectivas equivalencias en la TABLA NRO. 28.

TABLA NRO. 27. Rejilla para la valoración de la reseña crítica.

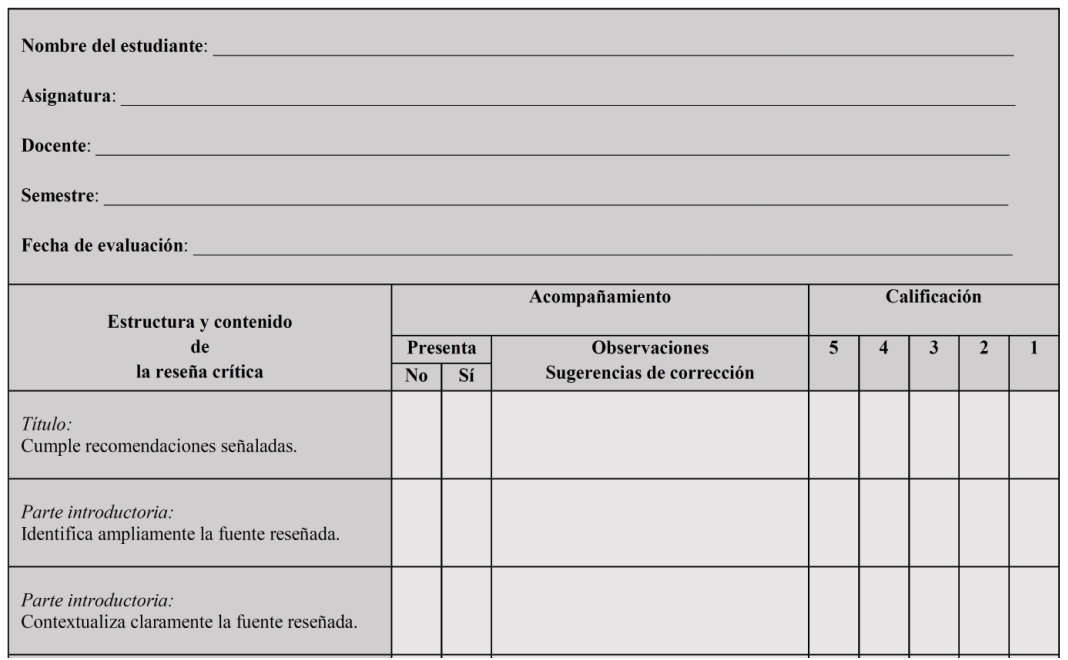




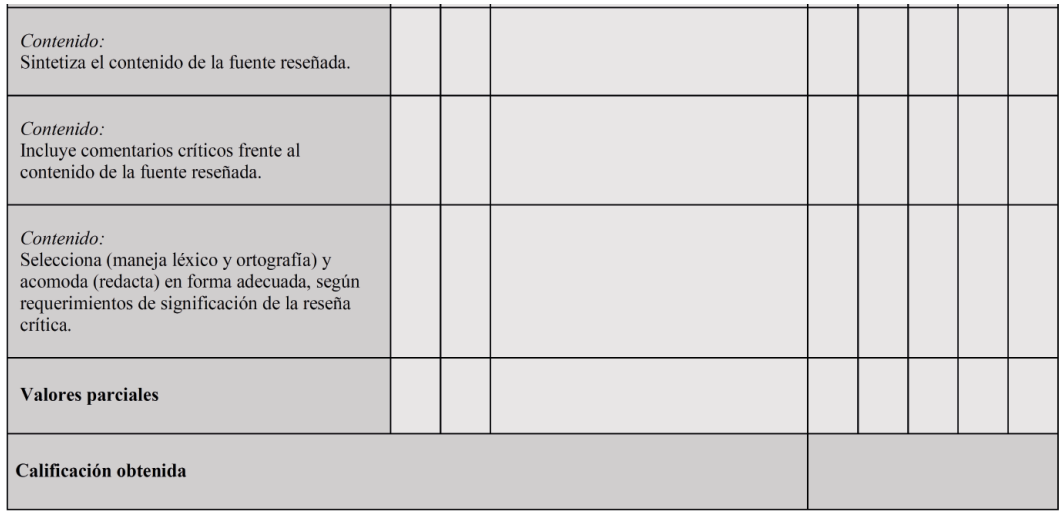

Elaboración propia.

TABLA NRO. 28. Equivalencias para la valoración de la reseña crítica.

\begin{tabular}{|c|c|c|c|}
\hline Puntos & $\begin{array}{c}\text { Equivalencias } \\
\text { en términos cualitativos }\end{array}$ & $\begin{array}{c}\text { Escala } \\
\text { puntos obtenidos }\end{array}$ & $\begin{array}{c}\text { Nota } \\
\text { obtenida }\end{array}$ \\
\hline 5 & Excelente: altamente adecuado. & 30 & 5.0 \\
\hline 4 & Bueno: adecuado (algunos errores u omisiones. & 24 & 4.0 \\
\hline 3 & Regular: inadecuado (muchos errores u omisiones). & 18 & 3.0 \\
\hline 2 & $\begin{array}{l}\text { Deficiente: no usa el recurso esperado o todos sus usos } \\
\text { son incorrectos. }\end{array}$ & 12 & 2.0 \\
\hline 1 & No sabe o no responde. & 6 & 1.0 \\
\hline
\end{tabular}

Elaboración propia. 


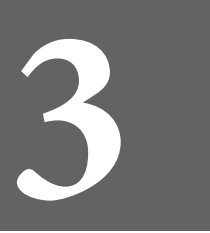

CAPÍTULO

TRES 


\section{Procesos y productos de escritura}

La escritura ha sido fundamental para la humanidad, no solo para guardar y transmitir el conocimiento que cada generación produce, sino para permitir la evolución del pensamiento razonado, lógico y diacrónico propio de lainteligencia.

Enseñar y promover el uso correcto de este legado, significa salvaguardar aquello que convierte en seres humanos; aquello que permite decir el conocimiento, pero también transformarlo. Esta primera acción comprende lo que ya se conoce a través de los libros, las enciclopedias y hasta del dominio público en la cotidianidad - asunto del cual se hablará-. Y la segunda hace referencia a la distancia que se tiene frente a dicho tema, a las posturas, al punto de vista, a la actitud crítica y propositiva frente a este. Al respecto, Agudelo et al. (2014) hacen referencia a los modelos explicativos de la escritura, aseverando lo siguiente:

En la escritura de un texto, no es suficiente tener claro el tema del cual se va a hablar [...] se requiere además mostrar el nivel de conocimiento que se tiene respecto a dicho tema y cómo nos identificamos como autores con dichos conocimientos (transformar el conocimiento). He aquí, entonces, las responsabilidades que tiene un autor con su texto, responsabilidades que evade al copiar o plagiar uno ajeno, cuando su autor sí se ha esmerado por cumplirlas (p. 183).

Ahora bien, para que la copia, el plagio, y hasta el miedo o la inseguridad al escribir, no tomen mayores rumbos en los entornos académicos, es necesario que, desde las facultades de Educación, sobre todo, se apoyen procesos formativos en materia escritural. Procesos que van encaminados, en este caso, a la construcción de los productos académicos más solicitados por los profesores en sus diferentes asignaturas dentro de la Facultad de Ciencias de la Educación de la Universidad 
Tecnológica de Pereira. Trabajo escrito, proyecto, ensayo, ponencia, entre otros; dado que no siempre se entienden por igual los requerimientos (en cuanto a normas de presentación, estructura, entre otras) que deben contemplar cada uno de dichos productos.

$\mathrm{Al}$ estar en los terrenos del discurso, como lo concibe Van Dijk (como se citó en Agudelo et al., 2014): «constructo producto de un ejercicio escritural» (p. 184), conviene mencionar sus dimensiones, también señaladas por el mismo autor y retomadas en esta fuente de la siguiente manera: el conocimiento, donde se incluyen los que fundamentan el texto escrito (conocimientos universales, culturales, nacionales, institucionales y personales); la lengua, quien escribe debe tener conocimiento acerca de la lengua con la cual se expresa en forma escrita, es decir, de los niveles que se involucran: fonético-fonológico, morfológico, sintáctico y semántico; y el contexto, donde:

Quien escribe debe ubicar su producto en un contexto, es decir, preparar su escrito para unos destinatarios determinados, a quienes solo les interesan (sic) unas temáticas determinadas; utilizar los códigos y canales más apropiados según sus necesidades de comunicación, y producir un mensaje claro, cuidándose denocaer enambigüedades. Quienescribetieneuna intención y por ello elige un léxico [...]. Se ubica aquí, entonces, el nivel pragmático del texto, en el cual se conjugan todos estos elementos contextuales para llevar una significación a través del texto (Agudelo, et al, 2014, pp184-185).

Recogiendo las consideraciones anteriores acerca del texto escrito, el objetivo del presente capítulo es suministrar documentos de apoyo o de guía a los docentes para clarificar, a nivel conceptual, procedimental y evaluativo, algunos productos deescritura, susceptibles de trabajarse en el aula a propósito del desarrollo de sus respectivas asignaturas, lo cual se convierte, de manera consecuente, en apoyo para los procesos de enseñanza y aprendizaje, liderados por cada uno de los integrantes del cuerpo profesoral. 
Conforme a lo anterior, este capítulo puede interesar a docentes universitarios que requieran de una guía para ayudar a sus estudiantes a planear la construcción de sus textos académicos, para retroalimentarles sus procesos de elaboración textual y para evaluar dichos textos. Por extensión, este capítulo (junto con los demás que componen la publicación), va orientado a la comunidad académica en general por los usos pedagógicos y didácticos que se sugieren en su interior, en pos de la formación de profesionales de la Educación para quienes es de carácter imprescindible el desarrollo de competencias escriturales.

Así, el presente capítulo consta de cuatro partes relacionadas conlosprocesosdeescrituraque deben ser puestos en práctica en un proceso formativo de educación superior. Las tres primeras corresponden a tipos de escritos académicos: trabajo escrito, ensayo argumentativo y ponencia. La cuarta y última parte corresponde a un apartado especial sobre la ortografía, el cual no solo ilustra sobre los aspectos ortográficos principales que se deben tener en consideración al momento de comunicar por escrito, sino que realiza una breve reflexión sobre la forma como ha impactado en la ortografía el uso de dispositivos electrónicos. En la actualidad, correctores informáticos en procesadores de texto, canales de comunicación digital, redes sociales, entre otros, han llevado a que las nuevas generaciones, las cuales se comunican por escrito, acudan a «licencias ortográficas» con la finalidad de hacer más ágil y efectiva la transmisión de un mensaje. Esta es una realidad que no se puede negar; por el contrario, debe ser adaptada para que en una aplicación de competencias comunicativas se realice un correcto uso del lenguaje y la ortografía. 


\subsection{Trabajo escrito}

\subsubsection{Concepto}

Según Agudelo, et al. (2014), el trabajo escrito constituye un texto que describe en forma ordenada una experiencia investigativa primaria y permite definir el grado de conocimientos y destrezas metodológicas en un área específica. Dada su versatilidad, resulta útil en diferentes niveles de formación académica, pues este tipo de trabajos suelen pedirse con cierta frecuencia en los colegios y en las universidades con el objetivo de que los estudiantes, en algún momento de su aprendizaje - sea inicial o sea final- consulten acerca de algunas temáticas.

Señalan, además, que este tipo de trabajos son llamados también trabajo de introducción a la investigación, según Icontec (2008); se caracterizan por la manera ordenada y clara en que se presenta la información y por privilegiar lo que Cassany (1993) postula como «estilo llano» (pp. 25-30). De ahí que en su redacción se requiera:

- Emplear un lenguaje adecuado para el lector y el contexto en que el trabajo se realiza.

- Tratar el tema de manera objetiva y precisa.

- Jerarquizar la información aportada, para garantizar la mayor coherencia posible.

- Usar un estilo claro, sencillo y conciso que beneficie las condiciones de legibilidad del texto.

- Respetar los protocolos formales propios de un campo del saber disciplinar o de un sistema de normas de presentación. 
Ahora bien, un buen trabajo escrito explora, descubre, compruebay expone. Su originalidad depende dela competencia escritural y de la comprensión lectora, porque este tipo de texto se convierte en la expresión gráfica y estructurada de un tema estudiado, donde se organizan y presentan los datos que han sido consultados en distintas fuentes o referencias. Estos textos deben poseer un objeto de estudio preestablecido para iniciar el proceso de investigación, descubrimiento y reunión de la información a tratar.

Todo trabajo universitario implica, en mayor o menor medida, una investigación que permite desarrollar competencias en aspectos importantes como:

- Planificación del trabajo a realizar.

- Uso de una metodología específica.

- Selección, jerarquización y crítica de fuentes de información.

- Jerarquización de conceptos, realizando una diferencia entre lo esencial y lo accidental.

- Estructuración ordenada y coherente del contenido.

- Redacción cuidadosa

La elaboración de trabajos fomenta, a la vez, actitudes como:

- Mayor conocimiento de las propias fortalezas y debilidades con el fin de potenciar las primeras y corregir las segundas.

- Disposición intelectual abierta y crítica.

- Rigor en la investigación.

- Perseverancia hasta lograr un trabajo bien hecho. 


\subsubsection{Procedimiento para su elaboración}

\subsubsection{Delimitación del tema}

Debe haber claridad sobre el tipo de trabajo solicitado, la amplitud de este y la fecha de entrega.

\subsubsection{Recolección de la información}

Esimportante definir el contenido del trabajo, paso inicial que permitirá realizar la búsqueda de la información necesaria para su elaboración.

\subsubsection{Organización de la información}

Una vez recogida la información, se debe organizary clasificar de acuerdo con un orden lógico, por las temáticas establecidas.

\subsubsection{Escritura del primer borrador}

Una vez confeccionado el esquema de la fase anterior, se elabora un borrador inicial, para tratar de expresar las ideas de manera organizada y lograr el máximo de concentración en el desarrollo del tema; y, de esta forma, no desviarse del mismo.

\subsubsection{Fuentes de información}

Se deben colocar al margen de la página y acorde a las normas establecidas para su presentación (APA o Icontec).

\subsubsection{Redacción final}

Deben aplicarse aquí indicadores de las propiedades del texto, según Cassany (2007): cohesión y coherencia, adecuación y estilística, presentación (canal escrito) y corrección gramatical. 


\subsubsection{Presentación (estructura formal)}

La estructura del trabajo escrito implica elaborar tres partes: las páginas preliminares, el contenido propiamente dicho y las páginas complementarias (Agudelo, et al., 2014), como se indica en la Figura NRO. 21 y como se explica brevemente en las siguientes líneas.

Figura NRo. 21. Partes de un trabajo escrito.
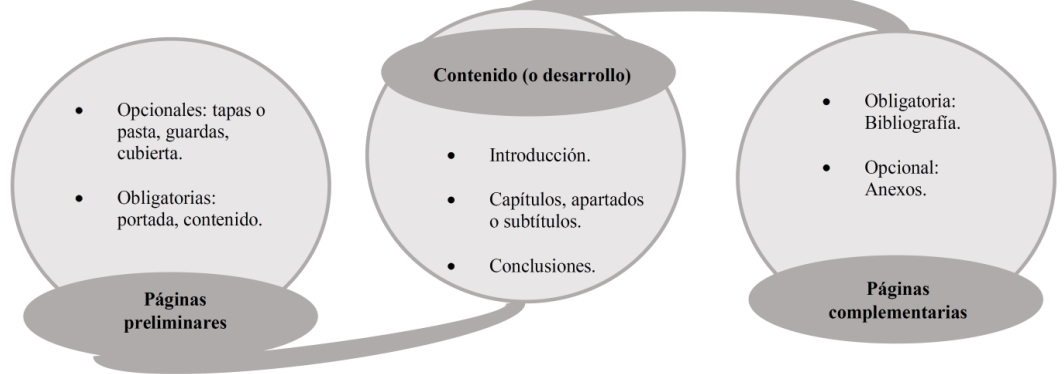

Tomado de Agudelo et al. (2014, p. 235).

\subsubsection{Páginas preliminares}

Portada: Es la puerta de entrada al trabajo, enuncia el título y el autor del mismo. También da cuenta de la institución que auspicia dicha investigación, así como la fecha y la ciudad. Estas partes han de ir distribuidas en la hoja tal como se presenta en la TABLA NRO. 29.

Contenido o índice: Es la relación de títulos y subtítulos que se desarrollan en el trabajo. Lo aconsejable en esta parte, es que se muestre claridad en tales categorizaciones. Por lo regular se acostumbra a usar nomencladores - siendo el decimal el más acostumbrado- por cuanto no se ubican con sangrías los títulos y subtítulos. En esta parte también se muestran las páginas donde pueden ser hallados directamente dichos títulosy subtítulos, desarrollados. 
TABLA NRO. 29. Ejemplo de portada del trabajo escrito.

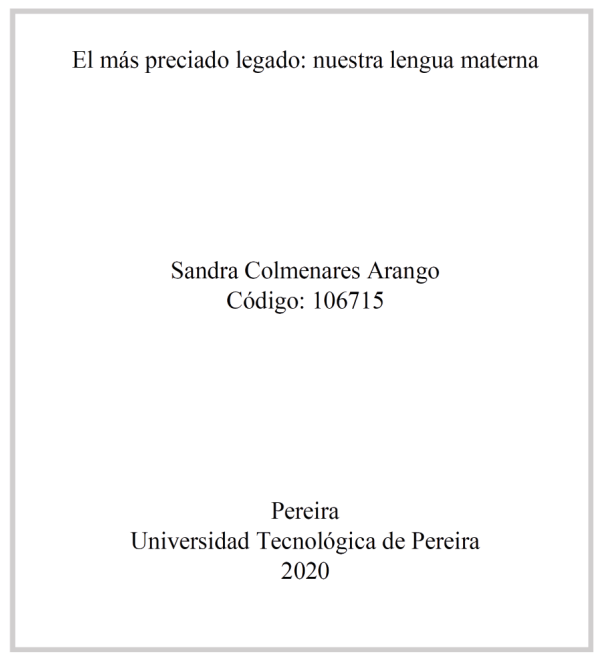

Elaboración propia.

Esta lista ordenada de capítulos o secciones permite a quien lee conocer los contenidos y la página de localización. En los trabajos escritos aparece después de la introducción yen algunos libros al final. Su función es conocer los temas y poder ubicarlos rápidamente. Un ejemplo del contenido o índice se muestra en la TABLA NRO. 30.

\subsubsection{Contenido o desarrollo}

El contenido del trabajo propiamente dicho, está integrado por una serie de apartes que requieren la producción textual del autor del mismo. Estas partes son: introducción, capitulos y conclusiones (Agudelo, et al, 2014); donde los segundos constituyen en sí el desarrollo o el cuerpo del trabajo. Cada apartado se explica como sigue:

Introducción: Haciendo una revisión etimológica, la palabra introducción proviene del latín y significa «acción y efecto de introducir algo o introducirse en algo» (DECEL, 2020, s. p.). Por 
tal motivo es la parte inicial de un trabajo; su función es ubicar al lector en el contexto del trabajo y sintetizar su desarrollo, con una previa alusión al cómo y al porqué de su realización.

TABLA NRO. 30. Ejemplo de contenido o índice del trabajo escrito.

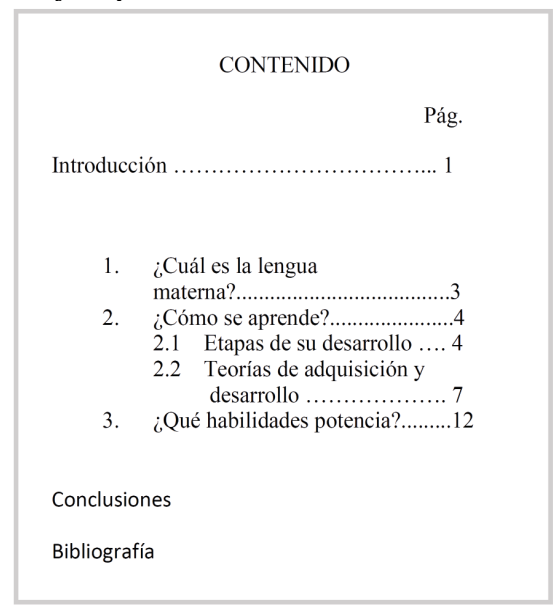

Elaboración propia.

En los trabajos científicos suelen encontrarse varias partes que se ubican al inicio de un trabajo, con un propósito común: familiarizar al lector con dicho trabajo. Sin embargo, cada una de esas partes responde a una intencionalidad diferente, como se precisa a continuación:

Prólogo. Se sitúa al inicio de un texto y es escrito por otro autor, normalmente para elogiar y presentar la importancia del trabajo que prologa.

Prefacio. Es elaborado por el autor del trabajo y allí le explica al lector aspectos procedimentales del mismo, incluyendo, por ejemplo, la razón que lo motivó a realizarlo y el reconocimiento a personas o instituciones que lo hicieron posible.

Introducción: El autor del trabajo presenta aspectos metodológicos del mismo, objetivos, estructura, exposición breve de las temáticas involucradas, entre otros. 
El orden de ubicación de estas partes preliminares del texto, es el mismo en que se presentó su breve explicación.

Desarrollo: También llamado cuerpo de un trabajo. Es la presentación del tema investigado como tal y, por consiguiente, la parte más extensa del escrito. Este cuerpo es una construcción dinámica que presenta de forma lógica y analítica lo que se advierte enla introducción.

Proporciona toda la información que se ha investigado en torno al tema, es decir, constituye el corazón y el alma del trabajo. En la primera parte se muestra el detalle de la situación; en la segunda, se analizan los datos obtenidos en la investigación; y, por último, se analizan e interpretan los resultados.

Conclusiones: Es la parte del trabajo escrito, donde se determinan claramente las inferencias, aspectos más relevantes y/o resultados obtenidos tras el proceso de investigación.

Las conclusiones pueden presentarse como la síntesis de aquellos resultados obtenidos al haber consultado sobre un asunto, como una recomendación, como una predicción o como un interrogante que le queda al lector después de haber obtenido claridad sobre un tema determinado. En este sentido, Shardakov (como se citó en Agudelo et al., 2014) señala tres clases de conclusiones: una retrospectiva, una proyectiva y una comparativa. Esta última invita a establecer comparaciones, bien sea con otro asunto de la misma naturaleza del que se está revisando o entre dos aspectos que se hayan mencionado dentro del revisado.

Hay que ser muy cuidadoso con la presentación de las conclusiones; se recomienda presentarlas en enunciados muy cortos y bien concentrados para evitar que se desvíe la atención del lector. Dichos enunciados suelen ir enmarcados por números o viñetas (o no necesariamente), dependiendo del gusto del autor y las reglas de la institución o cátedra que ejerce tutoría sobre el trabajo escrito. 


\subsubsection{Páginas complementarias}

Referencias bibliográficas: El uso correcto de la bibliografía es parte del compromiso y responsabilidad ética que tiene un autor. Las referencias a otros textos y citas literales deben estar relacionadas en la bibliografía de una manera completa para que un lector tenga la posibilidad de corroborar y cotejar la información que está adquiriendo. Si hay alguna alteración o vacío al relacionar las fuentes bibliográficas, se puede considerar como una falta grave que repercute en la credibilidad del autor, incluso se puede ver como un problema ético, ya que afecta la propiedad intelectual de otros autores. Así, cada vez que se obtenga y use información de un texto o de otro tipo de material, se debe hacer la respectiva referencia en la bibliografía. Esta práctica garantiza la fidelidad y verosimilitud del texto, así como el rigor con que fue elaborado.

En este apartado que va al final de los trabajos escritos, se referencia la bibliografía, palabra que deviene del griego biblion, que significa «libro» y de graphien, que significa «escribir» (DELCEL, 2020). La bibliografía enumera y referencia, en orden alfabético, las fuentes de las que ha sido obtenida la información; constituye el listado del grupo de textos que han sido utilizados como instrumentos de consulta al momento de la elaboración del trabajo escrito; suministra validez y base a los trabajos investigativos, siendo un soporte documental de gran interés para las personas que decidan profundizar en el tema. Se ubica por lo general al final del texto.

Anexos: Son textos que van como soportes del trabajo escrito, se caracterizan por ser escritos cortos como lecturas, informes, actas, tablas con datos estadísticos, entre otros. Se ubican al final del trabajo escrito, justo después de la bibliografía. Es conveniente enumerarlos, pues se debe hacer alusión a ellos por lo menos una vez a lo largo del texto. Si este solo tiene un anexo, no es necesario enumerarlo, pues al momento de hacer referencia a este -dentro del trabajo- se enuncia como ver anexo. 
Notas: No son estrictamente necesarias en trabajos escritos. No obstante, son válidas si el autor quiere reforzar las citas que no pudo incluir en el cuerpo o quiere dar cuenta de comentarios importantes sobre el tema. Cada nota suele tener un número correlativo y su extensión es de la preferencia del autor.

\subsubsection{Aplicación de normas en los trabajos escritos}

Agudeloet al.(2014) señalan que, debidoalcaráctercambiante de los sistemas de normas para la presentación de este tipo de trabajos, cuando se trate de aplicar las normas APA o Icontec, se puede acudir a las páginas web de estas instituciones con el fin de recabar información precisa y siempre actualizada en los momentos en que se requiera.

Para el momento actual, se remite a los siguientes enlaces, cuando de aplicar las Normas APA o Icontec, se trate:

Normas APA:

Https://www2.javerianacali.edu.co/sites/ujc/files/manual_de_ normas_apa_7 ${ }^{\mathrm{a}} \_$completo.pdf

Normas Icontec 1486:

https://www2.javerianacali.edu.co/sites/ujc/files/normas_ icontec.pdf

Estos autores enfatizan, en la importancia que tiene el respeto de las condiciones las cuales, a través de convocatorias o reglamentos internos, proponen las instituciones o sus agentes a la hora de solicitar la entrega de textos formales. De igual manera es importante no caer en el error común de mezclar criterios pertenecientes a distintos tipos de normas en un mismo trabajo escrito, dada la confusión que ello acarrea.

Ahora bien, cuando se trata de la presentación de otros tipos de textos, diferentes al trabajo escrito, pueden adoptarse algunas normas, ya sea de APA o de Icontec, sobre todo para el manejo de citas y referencias bibliográficas. 


\subsubsection{Evaluación}

Lo dicho en las anteriores líneas sobre el TRABAJO ESCRITO, se incluye en la rejilla que se presenta en la TABLA NRO. 31 . Su valoración desde lo cualitativo busca ofrecer la oportunidad de registrar observaciones y sugerencias de ajuste; desde lo cuantitativo, constituye un instrumento para brindar una calificación (nota) que dé cuenta de la calidad del trabajo que se revisa. Para determinar si se califica uno u otro valor, pueden consultarse las respectivas equivalencias en la TABLA NRO. 32.

TABLA NRO. 31. Rejilla para la valoración del trabajo escrito.

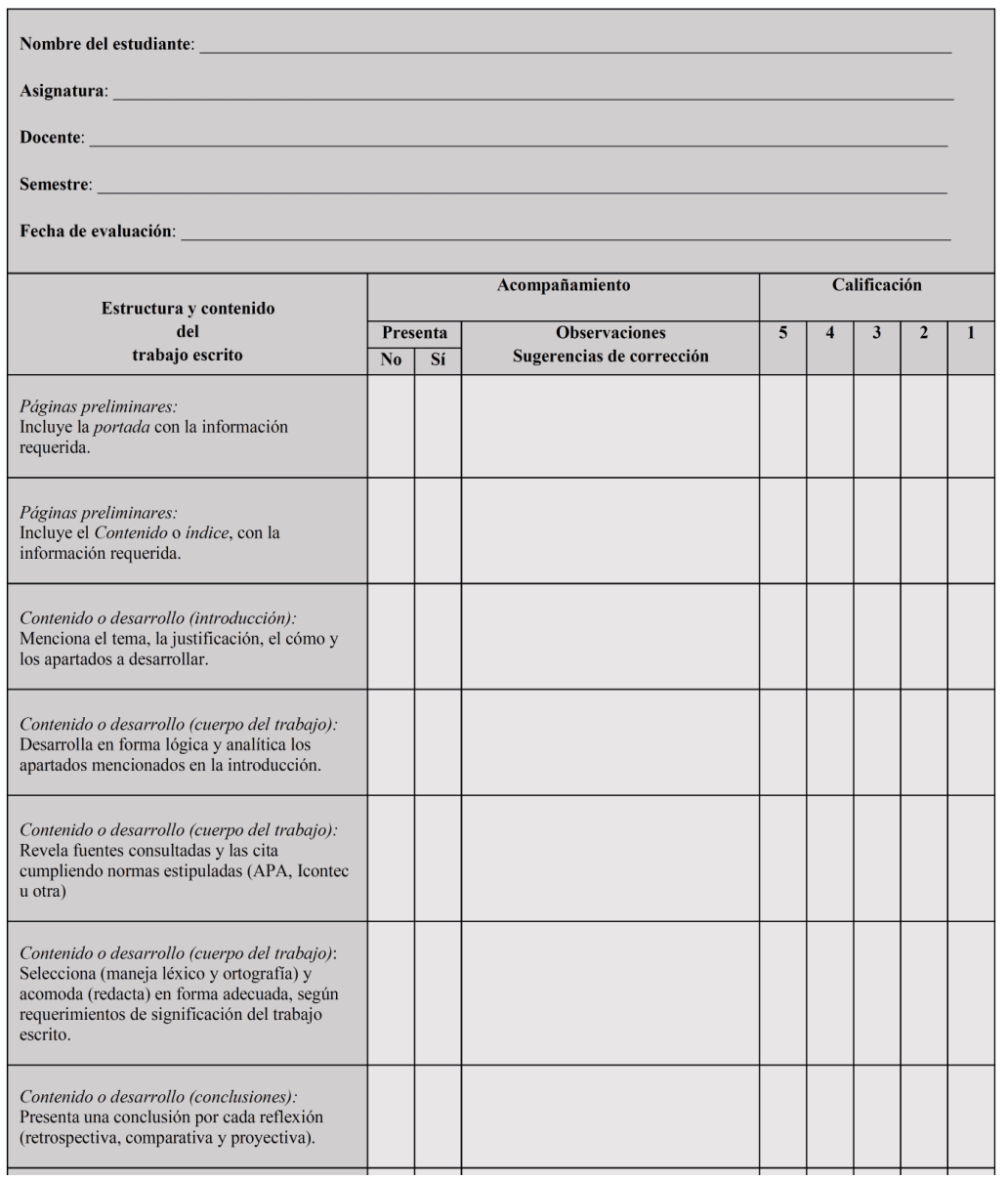




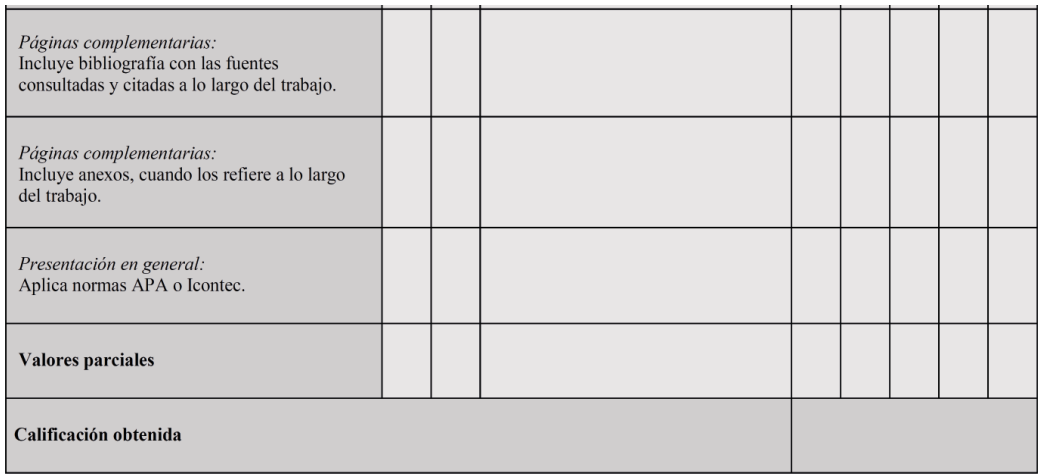

Elaboración propia.

TABLA NRO. 32. Equivalencias para la valoración del trabajo escrito.

\begin{tabular}{|c|l|c|c|}
\hline Puntos & \multicolumn{1}{|c|}{$\begin{array}{c}\text { Equivalencias } \\
\text { en términos cualitativos }\end{array}$} & $\begin{array}{c}\text { Escala } \\
\text { puntos obtenidos }\end{array}$ & $\begin{array}{c}\text { Nota } \\
\text { obtenida }\end{array}$ \\
\hline 5 & Excelente: altamente adecuado. & 50 & 5.0 \\
\hline 4 & Bueno: adecuado (algunos errores u omisiones. & 40 & 3.0 \\
\hline 3 & Regular: inadecuado (muchos errores u omisiones). & 30 & 2.0 \\
\hline 2 & $\begin{array}{l}\text { Deficiente: no usa el recurso esperado o todos sus usos } \\
\text { son incorrectos. }\end{array}$ & 20 & 1.0 \\
\hline 1 & No sabe o no responde. & 10 & \\
\hline
\end{tabular}

Elaboración propia.

\subsection{Ensayo argumentativo}

\subsubsection{Concepto}

Según las convergencias entre muchos de los escritores y teóricos contemporáneos (Cassany, 1995; Pérez, 2000; Vásquez, 2004; Álvarez, 2005), la escritura ensayística demanda diversos procesos en el mundo académico para la formación disciplinar y para el desarrollo del pensamiento razonado. Uno de los conceptos más acertados de los últimos tiempos lo plantea Vásquez (2004), al señalar que: 
El ensayo es un género híbrido en cuanto participan en él elementos de dos categorías diferentes. Por una parte, es didáctico y lógico en la exposición de las nociones o ideas; pero, además, por su flexibilidad efusiva, por su libertad ideológica y formal, en suma, por su calidad subjetiva, suele tener también un relieve literario (p. 13).

De otra parte, para concretar lo que es el ensayo argumentativo conviene referenciar lo expuesto por Pérez (2000), cuando precisa:

En términos generales, puede caracterizarse el ensayo argumentativo como un escrito en el que se toma posición sobre una temática, una opinión o una problemática determinada, se sustenta dicha posición a través de argumentos y se accede a unas conclusiones. De este modo, el objeto de un ensayo argumentativo es algo susceptible de discusión; o en otras palabras, en el ensayo argumentativo no se está frente al problema de la verdad o la falsedad, sino más bien frente al problema de la verosimilitud (p. 13).

\subsubsection{Procedimiento para su elaboración}

Para la realización de un ensayo argumentativo, pueden tenerse en cuenta las siguientes actividades:

\subsubsection{Delimitación del campo temático}

Dado que el ensayo argumentativo se sitúa en un campo de significados específicos, se debe delimitar el campo temático del que se ocupa y mostrar la pertinencia, alcances y límites.

\subsubsection{Toma de posición}

La característica central del ensayo argumentativo es la toma de posición, pues quien escribe el texto plantea un punto de vista sobre la temática en discusión; de lo contrario, se encontraría frente a otro tipo de texto. La toma de posición puede ser 
una opinión, un juicio, una valoración o una evaluación frente a una situación $x$, una teoría o un procedimiento, para algunos autores llamado hipótesis (después de un proceso de confirmación o constatación, se convierte en tesis). Con base en la toma de posición y teniendo en cuenta el auditorio o interlocutor a quien se dirige el texto, se selecciona el tipo de argumentos.

\subsubsection{Argumentos}

Para apoyar la hipótesis planteada, deben presentarse argumentos. Díaz (2002) afirma: «un argumento bien conformado tiene una organización interna coherente, en la que sus elementos constituyentes mantienen una relación de dependencia lógica» (p. 63). Él cuenta con partes que lo estructuran, como son: el punto de vista o conclusión, la fundamentación y el garante. La fundamentación acude a la teoría (definiciones, clasificaciones), también a hechos, evidencias, comparaciones, casos, ejemplos, entre otros; y el garante, por su parte, es "el principio cuya validez se presume aceptada en el seno de una sociedad» (Díaz, 2002, p.73); es una afirmación, implícita o explícita. que permite establecer la relación ( $\mathrm{y}$ el grado de validez) entre el punto de vista o conclusión y la fundamentación ${ }^{11}$.

Cabeenfatizarquelosejemplosylascomparacionesson recursos útiles que apoyan los argumentos desde la fundamentación -como se señala en la estructura del argumento- pero no se convierten en condición necesaria al momento de presentar los argumentos. Hay campos temáticos y posiciones que se prestan o no para incluir ejemplos o comparaciones al momento de argumentar.

11 En caso de requerir un acercamiento mayor a la forma como se construyen, analizan y ejemplifican las hipótesis, se puede consultar el libro Pensamiento y palabra: pensar, argumentar, hablar, leer y escribir, donde sus autores Agudelo et al. (2014) hacen un despliegue detenido en dicho sentido. 


\subsubsection{Conclusiones}

En el ensayo argumentativo, el desarrollo de la toma de posición y el planteamiento de argumentos, generalmente, conducen a un cierre. La conclusióndebe derivarse lógicamente de la hipótesis y los argumentos; sin embargo, es posible que en algunos casos no se plantee de manera explícita. Hay ensayos que dejan en manos del lector la elaboración de las conclusiones e implicaturas, por lo que se deja una pregunta abierta para la reflexión.

\subsubsection{Plan argumentativo}

Es necesario quelas diferentes partes delensayo argumentativo se organicen siguiendo un plan o eje argumental. Al respecto, Pérez (2000) hace la siguiente aseveración:

Si no existe un plan argumental se podrá estar frente a un listado de argumentos inconexos, o se podrá estar frente a un texto en el que la conclusión no se deriva de los argumentos y la tesis (idea o ideas) planteadas. De este modo, el tipo de nexo semántico existente entre uno y otro componente, define el nivel de coherencia del texto (p. 13).

Un ejemplo de secuencia argumentativa puede ser el que muestra la Figura Nro. 22.

En síntesis, un ensayo es una producción en la que se toma posición sobre una temática, un tópico identificado en un libro, una opinión sobre un aspecto cualquiera de la vida, una problemática determinada, entre otros asuntos susceptibles de expresar acuerdo o desacuerdo. Acto seguido, se realiza una disertación donde se sustente dicha posición, donde se expliciten los "porqué» de la afirmación inicial (o toma de posición); es decir, se hace una presentación de los argumentos necesarios y suficientes para dicha sustentación. Por último, debe concluirse esta producción escritural. 
De este modo, el propósito de un ensayo argumentativo es algo susceptible de discusión, como lo son todos los escritos en su posibilidad de apertura. Tradicionalmente, en su estructura, la comunidad académica ha validado la relación entre introducción (que incluye la toma de posición), desarrollo (despliegue de argumentos) y conclusiones. Esta tiene una presentación formal, donde, a tal estructura, se le antepone un título, el cual puede ser sugestivo o metafórico (no llano), que llame la atención e invite a la lectura del texto. Al final se ubican las referencias bibliográficas; estas indican las fuentes que ayudaron a inspirar la delimitación y contextualización del campo temático, la toma de posición o el despliegue mismo de los argumentos. La autoría del ensayo se puede ubicar bien sea al comienzo o al final.

FIGURA NRO. 22. Ejemplo de secuencia argumentativa.
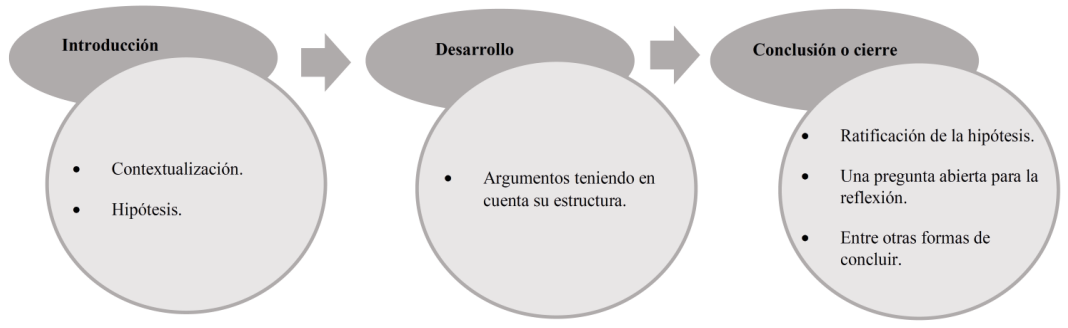

Elaboración propia.

\subsubsection{Algunas características del ensayo argumentativo}

\subsubsection{Consistencia en los enunciados}

Se requiere que los conceptos básicos y las connotaciones empleadas en la argumentación no resulten contradictorias, ambiguas o confusas. Si ameritan una aclaración, esta debe darse entre guiones, entre paréntesis - como frases aclarativasa través de alusiones directas o indirectas, $o$ a través de notas al pie de página. 
Es importante que en el ensayo argumentativo no se incurra en contradicciones entre los enunciados. Es decir, que no se afirme y se niegue el mismo o los mismos enunciados en el escrito a no ser que la presentación de una contradicción haga parte de una estrategia argumentativa; en este caso, esa contradicción deberá ser explicada en el desarrollo del escrito.

\subsubsection{Adecuación al auditorio}

Es necesario anticipar o pensar en el tipo de interlocutor o lector a quien va dirigido el ensayo o en quienes posiblemente irán a leer o escuchar el trabajo realizado. Lo que supone seleccionar un tipo de léxico y un tipo de argumentos precisos.

\subsubsection{Verosimilitud versus verdad}

El ensayo argumentativo no pretende probar una verdad absoluta, sino valorar argumentos a favor de una toma de posición. De este modo, no interesa probar si se está frente a una verdad innegable o controvertible en términos de verdadero/ falso, interesa reconstruir las condiciones de consistencia interna y la solidez de un discurso. En general, la idea de verosimilitud debe ser entendida como la consistencia interna del escrito, que va más allá del apoyo en fuentesbibliográficas. Es decir, se refiere a la condición del escrito de conformar un todo articulado y coherente, en el que los diferentes componentes juegan un papel en función de propósitos argumentativos.

\subsubsection{La flexibilidad en su estructura}

Quien escribe un ensayo argumentativo discurre libremente, se apropia de su escrito y se siente seguro de lo que dice a través de sus argumentos. Lo importante, en cuanto a la estructura que utilice, es que siga un plan argumental, el cual define la secuencia de la organización de los componentes del escrito. Por ejemplo, puede encontrarse un ensayo argumentativo en el que se parta de una conclusión, luego se presenten los argumentos, 
para después dar paso a la tesis de trabajo; o puede encontrarse un escrito en el que se mezclen argumentos con ejemplos, antes de plantear la hipótesis. Es importante comprender la escritura del ensayo argumentativo como una búsqueda de estructura.

Así, la estructura que se presenta en la primera parte de este documento de apoyo pretende orientar hacia una didáctica del ensayo, pero no quiere decir que todos los ensayos se encuentren con dicha estructura.

\subsubsection{Precisión y adecuación lexical}

Se refiere a la selección de un tipo de lenguaje en atención al interlocutor del texto, a una intencionalidad y a un contexto de comunicación. Un texto configura un campo semántico. Por ejemplo, en un ensayo donde el campo temático y la toma de posición apuntan a una disciplina u oficios específicos, las expresiones que se utilicen corresponderán a los tecnolectos; pero si estos (campo temático y toma de posición) giran en torno a cuestiones inherentes a los grupos sociales, entonces se acudirá a los sociolectos. En todo caso, quien escriba un ensayo, tendrá en cuenta estos usos particulares de los términos: usos regionales, usos especializados, usos cotidianos, usos literarios, entre otros.

\subsubsection{Intertextualidad}

En la producción de textos, en muchos casos se toma información de distintas fuentes o se establecen relaciones más o menos explícitas con otros textos. A estos vínculos se les denomina relaciones intertextuales. Es necesario analizar y reconocer en qué casos se está introduciendo información intertextual y explicitar su origen. De este modo cobra lugar la cita, la nota al pie de página, la alusión, el uso de estructuras o de estilos tomados de otros autores o de otras épocas. Las referencias a épocas, culturas o contextos socio-históricos son también tipos de relaciones intertextuales. 
Cabe destacar entonces, que las citas son recursos claves en la escritura del ensayo, no solo como apoyos para lograr la credibilidad y legitimidad de los argumentos o como soportes del plan argumentativo, sino también como posibilitadores de la construcción del universo conceptual en el cual se desarrolla, sirviendo como evidencias de la configuración intertextual.

\subsubsection{Contexto de enunciación}

Entendido como la situación de comunicación representada a través de los discursos y los textos: escenarios, interlocutores y sus roles, intereses, ideologías en juego, variables políticas, entre otras condiciones, las cuales definen el contexto de enunciación. Los diferentes tipos de contexto determinan los usos sociales de los textos o la selección de un léxico particular o de un registro lingüístico. De este modo, puede llamarse coherencia pragmática a la adecuación de un texto y un discurso a su contexto.

\subsubsection{Intencionalidad}

Los textos se producen en atención a un propósito comunicativo y de acción. Con ellos se busca que pase algo, que alguien se persuada, que alguien comprenda, que alguien se informe, que alguien acuda a la cita, en fin, que alguien se provoque. Según las intenciones comunicativas se tendrán diferentes tipos de discurso, a saber: persuasivo, informativo, descriptivo, explicativo, entre otros.

\subsubsection{Recursos lingüísticos}

El ensayo argumentativo como escrito académico debe garantizar que existan nexos explícitos entre sus diferentes elementos, para lo cual se utilizan recursos como:

- Formas personales para asumir una posición: "Considero que...», «Me parece que...», «Desdenuestro punto devista...», "A nuestro parecer...». Son formas que 
permiten indicar desde dónde se habla. En este caso, la primera persona, bien sea del singular (yo) o del plural (nosotros).

- Fórmulas para introducir las citas o alusiones: «Según X persona»; verbos de opinión en indicativo o infinitivo: "X afirma que...»; para valorar una idea: «De acuerdo con X...»; para desvalorizar una idea: «X pretende que..., insinúa que..., desea que...».

- Conectores y organizadores textuales para garantizar la cohesión y tejer el plan argumental: «Examinaré diferentes aspectos de la polémica...», «En primer lugar...», «En segundo lugar...»; organizadores causales como "La razón de...», "Ya que se afirma que...», «Puesto que...», "En consecuencia...», «Por lo tanto...», entre otros.

- Modalizaciones del enunciado como expresiones de certeza, "Estoy convencido de...», "Seguramente...», «Sin lugar a dudas...»; expresiones de probabilidad: «Parece ser que...», "Probablemente...»; y expresiones de duda como «No estoy seguro de...», «Es improbable que...».

- Restricciones: «A menos que...», «Excepto si...».

- Fórmulas concesivas: "Reconozco que...», «Pero...», «Tengo que admitir que...», «Sin embargo...», entre otras.

\subsubsection{Presentación (estructura formal)}

De acuerdo con lo mencionado en el apartado anterior, la estructura del ensayo argumentativo se puede concebir así: 
- Título.

- Contenido: Prosa seguida con Introducción, desarrollo o disertación y cierre o conclusión.

- Referencias bibliográficas.

- Autoría.

\subsubsection{Evaluación}

Lo dicho en las anteriores líneas sobre ENSAYO ARGUMENTATIVO, se incluye en la rejilla que se presenta en la TABLA NRO. 33. Su valoración desde lo cualitativo busca ofrecer la oportunidad de registrar observaciones y sugerencias de ajuste; desde lo cuantitativo, constituye un instrumento para brindar una calificación (nota) que dé cuenta de la calidad del trabajo que se revisa. Para determinar si se califica uno u otro valor, pueden consultarse las respectivas equivalencias en la TABLA NRO. 34.

TABLA NRO. 33. Rejilla para la valoración del ensayo argumentativo.

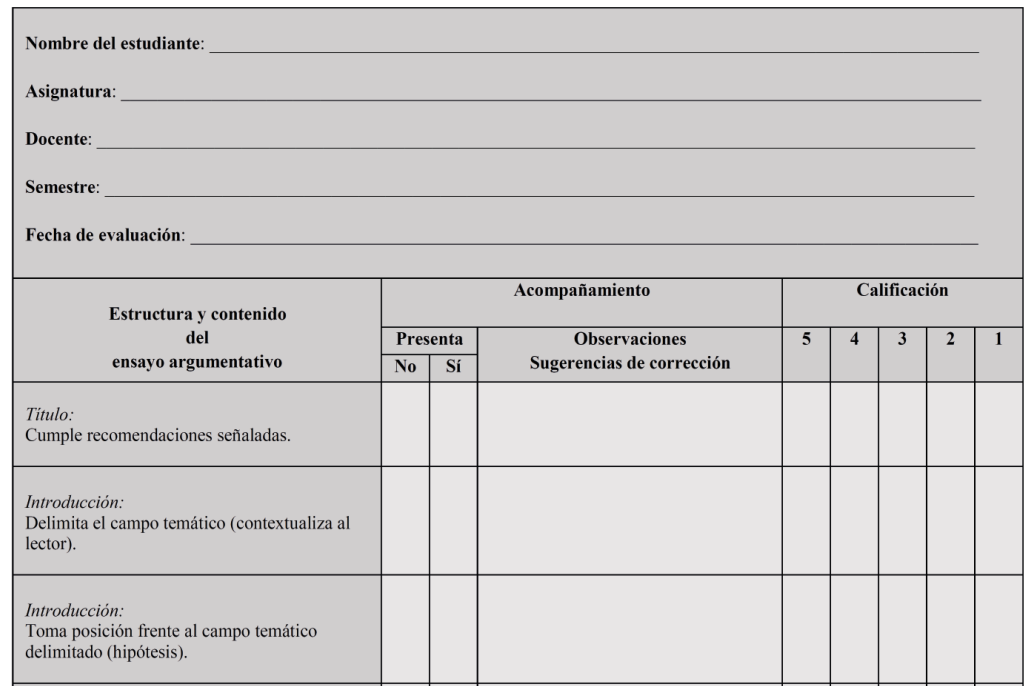




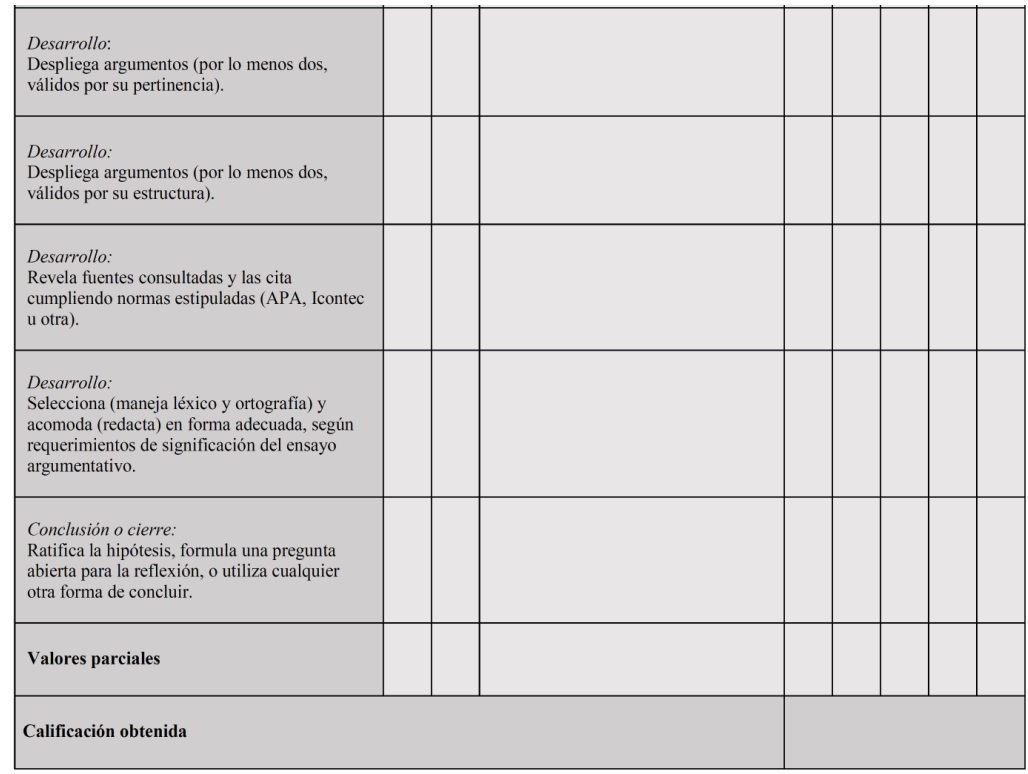

Elaboración propia.

TABLA NRO. 34. Equivalencias para la valoración del ensayo

argumentativo.

\begin{tabular}{|c|l|c|c|}
\hline Puntos & \multicolumn{1}{|c|}{\begin{tabular}{c}
\multicolumn{1}{c|}{ Equivalencias } \\
en términos cualitativos
\end{tabular}} & $\begin{array}{c}\text { Escala } \\
\text { puntos obtenidos }\end{array}$ & $\begin{array}{c}\text { Nota } \\
\text { obtenida }\end{array}$ \\
\hline 5 & Excelente: altamente adecuado. & 40 & 5.0 \\
\hline 4 & Bueno: adecuado (algunos errores u omisiones. & 32 & 4.0 \\
\hline 3 & Regular: inadecuado (muchos errores u omisiones). & 24 & 3.0 \\
\hline 2 & $\begin{array}{l}\text { Deficiente: no usa el recurso esperado o todos sus usos } \\
\text { son incorrectos. }\end{array}$ & 16 & 2.0 \\
\hline 1 & No sabe o no responde. & 8 & 1.0 \\
\hline
\end{tabular}

Elaboración propia.

\subsection{Ponencia}

\subsubsection{Concepto}

Desde que la ciencia positiva occidental se regularizó en los siglos XVII y XVIII, existe un consenso en la comunidad académica respecto a sus resultados de manera escrita. Con el tiempo, se 
han ido estableciendo estándares para transmitir los resultados de investigaciones y estudios científicos, siendo uno de ellos los espacios en que los especialistas de cada disciplina se congregan a debatir sobre las novedades y avances en sus materias.

Ahora bien, la manera como se define el discurso que sintetiza los resultados que un científico presenta frente a un público especialista, se llama ponencia. Por esta razón, este tipo de escrito hace parte del lenguaje especializado de la ciencia y es una de las formas más evolucionadas de un relato argumentado. Tradicionalmente las ponencias son leídas, por esta razón, siempre están escritas. En la actualidad, con los apoyos audiovisuales, una ponencia también puede ser una forma de exposición, aunque exista un texto escrito que se publica como parte del resultado de una investigación científica, el cual es distinto al artículo. Así lo ratifica Conto (2015), cuando afirma «una ponencia es una actividad generalmente académica, mediante la cual el ponente presenta, declara, informa, afirma, propone, comunica o hace una reseña oral, sobre un tema determinado y concreto» (pp. 1-4).

La comunicación que se realiza ante la comunidad a la cual fue sometida, tiene por sí misma el objetivo de llegar a ser publicada (Conto, 2015 pp. 1-4), pues tiene como finalidad servir para futuras referencias académicas que alimenten otras ponencias sobre la temática planteada.

A diferencia de otros textos, la ponencia, al contener un componente oral, se dirige constantemente a un auditorio al que se le plantea una "posición» o "propuesta» cuyo desarrollo debe ser justificado o defendido. El tono del texto por lo tanto es de particular dado que pareciera requerir el de una cordial confrontación y diálogo intersubjetivo. Adicional a esto, el formato se regula por los determinantes que se establecen en el marco del congreso, simposio o coloquio. Así «estas presentaciones suelen tener un tiempo predeterminado, por lo 
que el ponente requiere seleccionar la información a presentar y elegir una estrategia acorde con el tiempo disponible» (Sánchez et al., 2017, p. 3).

La ponencia se caracteriza por:

- Analizar un objeto de estudio.

- Ser breve pero no falto de exhaustividad.

- Tener en cuenta aspectos que facilitan su lectura y, por ende, la comunicación con el auditorio que la escucha.

- La ponencia es una herramienta útil e importante en el desarrollo profesional de los estudiantes de cualquier tipo de formación superior, y más aún, de estudiantes de Licenciatura, pues permite trabajar lascuatro habilidades del lenguaje; esto mediante la planeación minuciosa, la escritura y la lectura, la presentación clara, el habla y la escucha activa, y la discusión con el público.

\subsubsection{Procedimiento para su elaboración}

Sánchez et al. (2017) señalan que para la elaboración de una ponencia el primer paso es identificar el ámbito en que será presentada, esto permitirá identificar el propósito específico del texto. Existen varios usos para una comunicación a modo de ponencia; a continuación, se enumeran los másfrecuentes:

\subsubsection{Divulgación académica}

En este caso, el objetivo de la ponencia se centra en difundir el conocimiento producto de una investigación. Para ello, es fundamental que el ponente utilice un lenguaje riguroso $\mathrm{y}$ académico. Este tipo de ponencia es frecuente para espacios como Congresos, Seminarios, Simposios y Paneles; en los que es importante enviar un resumen de lo que se va a presentar, ya sea para cumplir un filtro de selección y/o para el registro de las memorias. 


\subsubsection{Seminario alemán o de investigación}

En esta metodología el objetivo es despertar el interés y la discusión en los participantes. El ponente persuade al grupo mediante la reflexión de la bibliografía y sugieren puntos de discusión concretos. Este tipo de seminarios suelen usarse más en ámbitos formativos que en divulgativos de las disciplinas de las ciencias.

\subsubsection{Políticas públicas}

Para esta tipología de ponencia se hace indispensable la identificación de un problema que esté vinculado a una política pública; a partir de él se debe plantear un objetivo que lo exponga y argumente su relevancia. Para este caso, el texto es «necesariamente argumentativo porque busca persuadir a la audiencia» (Sánchez et al., 2017, pp. 4-5).

\subsubsection{Derecho administrativo}

Tiene como objetivo plantear o no el debate a una iniciativa legislativa.

Después de identificar el ámbito en el que será presentada la ponencia, se debe realizar una planeación previa, la cual se torna importante, ya que el ejercicio consciente de planear garantiza la coherencia de dicha presentación. De esta forma, se asegura un mensaje claro y efectivo dirigido al público. Se debe tener en cuenta la audiencia a quién se dirige y el contexto en el que se presenta.

La ponencia puede ser planeada a través de un texto escrito, una presentación en Power Point u otra aplicación -o ambas estrategias-. En cualquier caso, se debe hacer énfasis en la presentación oral, dado que esta es la característica diferenciadora. A continuación, en la TABLA NRO. 35 se presentan las recomendaciones aportadas por Sánchez et al. 
(2017), donde se ilustra con mucha precisión la manera en que deben ser abordadas las competencias comunicativas en una ponencia.

\subsubsection{Presentación (estructura formal)}

La ponencia tiene una estructura muy similar a la del ensayo argumentativo, pues ambos tipos de escrito se caracterizan por argumentar. Sin embargo, la diferencia radica en el contenido de cada una de las partes que los conforman y, por supuesto, en la intencionalidad con la cual se presenta cada uno de ellos. Esto podrá apreciarse en la TABLA NRO. 36, donde se presenta la estructura de la ponencia, con la correspondiente explicación.

\subsubsection{Evaluación}

Se presenta este formato de valoración de una ponencia, respondiendo a la necesidad de acompañamiento que tiene el estudiante para este tipo de escrito. Igualmente se tiene en cuenta el formato utilizado convencionalmente por universidades colombianas y latinoamericanas. Cabe anotar que, por lo regular estas instituciones, como control previo a la evaluación, identifican estos trabajos tal como se muestra en la TABLA NRO. 37 .

Lo dicho en las anteriores líneas sobre PONENCIA se incluye en la rejilla presentada en la TABLA NRO. 38. Su valoración desde lo cualitativo busca ofrecer la oportunidad de registrar observaciones y sugerencias de ajuste; desde lo cuantitativo, constituye un instrumento para brindar una calificación (nota) que dé cuenta de la calidad del trabajo que se revisa. Para determinar si se califica uno u otro valor, pueden consultarse las respectivas equivalencias en la TABLA NRO. 39. 
TABLA NRO. 35. Las competencias comunicativas en la ponencia.

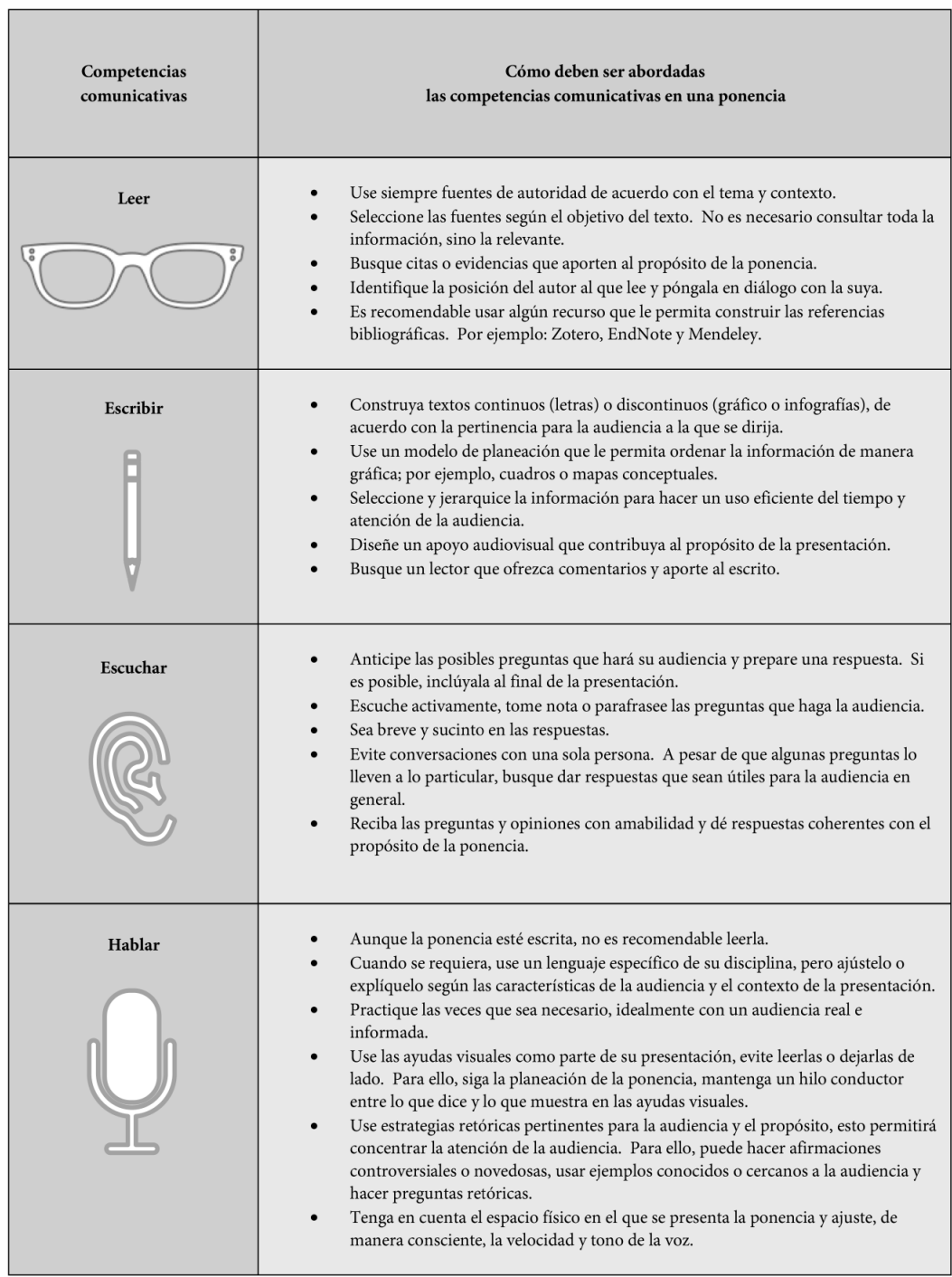

Basada en Sánchez et al. (2017). 
TABLA NRO. 36. Estructura de la ponencia.

\begin{tabular}{|c|c|}
\hline Partes de la ponencia & Explicaciones y/o recomendaciones \\
\hline $\begin{array}{c}\text { Título } \\
\text { y } \\
\text { autoría }\end{array}$ & $\begin{array}{l}\text { El título: } \\
\text { - Da cuenta del contenido y sugiere el propósito de la ponencia. } \\
\text { - Debe ser corto, concreto y llamativo. } \\
\text { La autoría: } \\
\text { - Se anuncia. }\end{array}$ \\
\hline $\begin{array}{c}\text { Resumen } \\
y \\
\text { palabras clave }\end{array}$ & $\begin{array}{l}\text { Resumen: } \\
\text { - Se enuncian elementos principales de la ponencia. } \\
\text { - Se alude a la hipótesis, el objetivo principal, las fuentes de información y los } \\
\text { resultados presentados en la ponencia. } \\
\text { Palabras clave: } \\
\text { - Señalan los términos o frases que recogen los aspectos centrales de la ponencia. }\end{array}$ \\
\hline Introducción & $\begin{array}{l}\text { - Se cautiva el interés de la audiencia y se da una visión general del tema. } \\
\text { - Se usan estrategias retóricas para llamar la atención de la audiencia. } \\
\text { - Se puede agradecer de manera breve y concreta, si lo requiere. } \\
\text { - Se expone el objetivo o propósito de la ponencia. } \\
\text { - } \quad \text { Se como el potencial alcance del abordaje planteado. } \\
\text { - Sesultados y la información que se presenta. } \\
\text { - Se hace una alusión tanto a la metodología, como a las fuentes de información y a } \\
\text { los principales referentes teóricos en los que se apoya. }\end{array}$ \\
\hline Cuerpo & $\begin{array}{l}\text { Estructura: } \\
\text { - Se incluye el mensaje principal que se desea transmitir. } \\
\text { - } \quad \text { pe exponen y ordenan evidencias para cumplir con el propósito específico de la } \\
\text { - Debe garantizarse que la exposición sea fácil de seguir y atractiva para la } \\
\text { audiencia. } \\
\text { Metodologia: } \\
\text { - Se usa el tipo de evidencia requerido según el propósito de la ponencia y el } \\
\text { - ámbito en que se presenta. } \\
\text { - Se debe apoyar en un marco de referencia teórico. } \\
\text { - } \text { se trata de que el ponente transmita toda la información que tiene, pues el exceso } \\
\text { - } \quad \text { Plantear con claridad un enfoque, las técnicas e instrumentos utilizados. } \\
\text { Resultados: } \\
\text { - Debidenciar un tratamiento ético de la información. } \\
\text { - Deben ser consistentes con la metodología planteada. } \\
\text { - Evidenciar claridad en el aporte crítico, apoyado en argumentos validados en } \\
\end{array}$ \\
\hline Conclusión & $\begin{array}{l}\text { - } \quad \text { Se requieren oraciones breves y sucintas que resuman lo expuesto. } \\
\text { - Se vuelve al objetivo del trabajo o propósito de la ponencia, pero ya no con } \\
\text { intenciones de mostrar evidencias, sino con la idea de concluir. } \\
\text { - Se debe desarrollar una relación y contraste de los resultados obtenidos. } \\
\text { - Se debe valorar el alcance del objetivo planteado. } \\
\text { - Se debe demostrar cómo los resultados impactan a la comunidad, personas, } \\
\text { grupos, entidades e instituciones a las que fue dirigido el trabajo. } \\
\text { Se pueden incluir reflexiones, recomendaciones, preguntas y sugerencias que } \\
\text { aporten a la discusión académica y a futuras investigaciones. }\end{array}$ \\
\hline Referencias bibliográficas & $\begin{array}{l}\text { - Se deben presentar las referencias bibliográficas utilizadas, siguiendo las normas } \\
\text { de citación estipuladas. }\end{array}$ \\
\hline
\end{tabular}

Basada en Sánchez et al. (2017, pp. 3-4). 
TABLA NRO. 37. Esquema para identificar la ponencia.

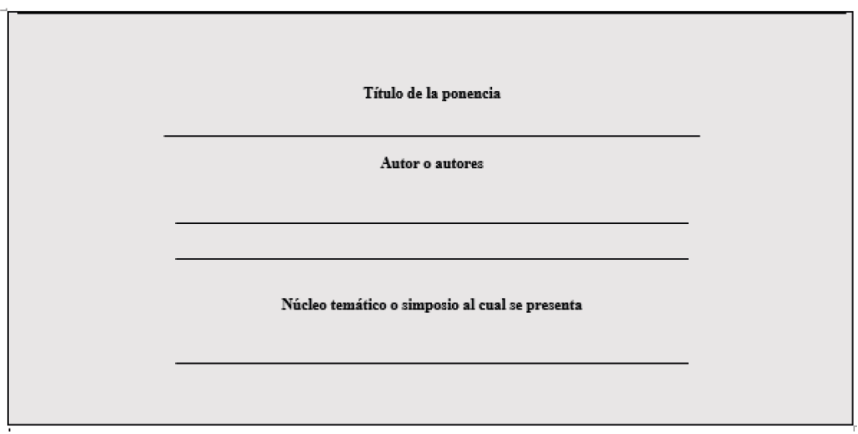

Elaboración propia.

TABLA NRO. 38. Rejilla para la valoración de la ponencia.

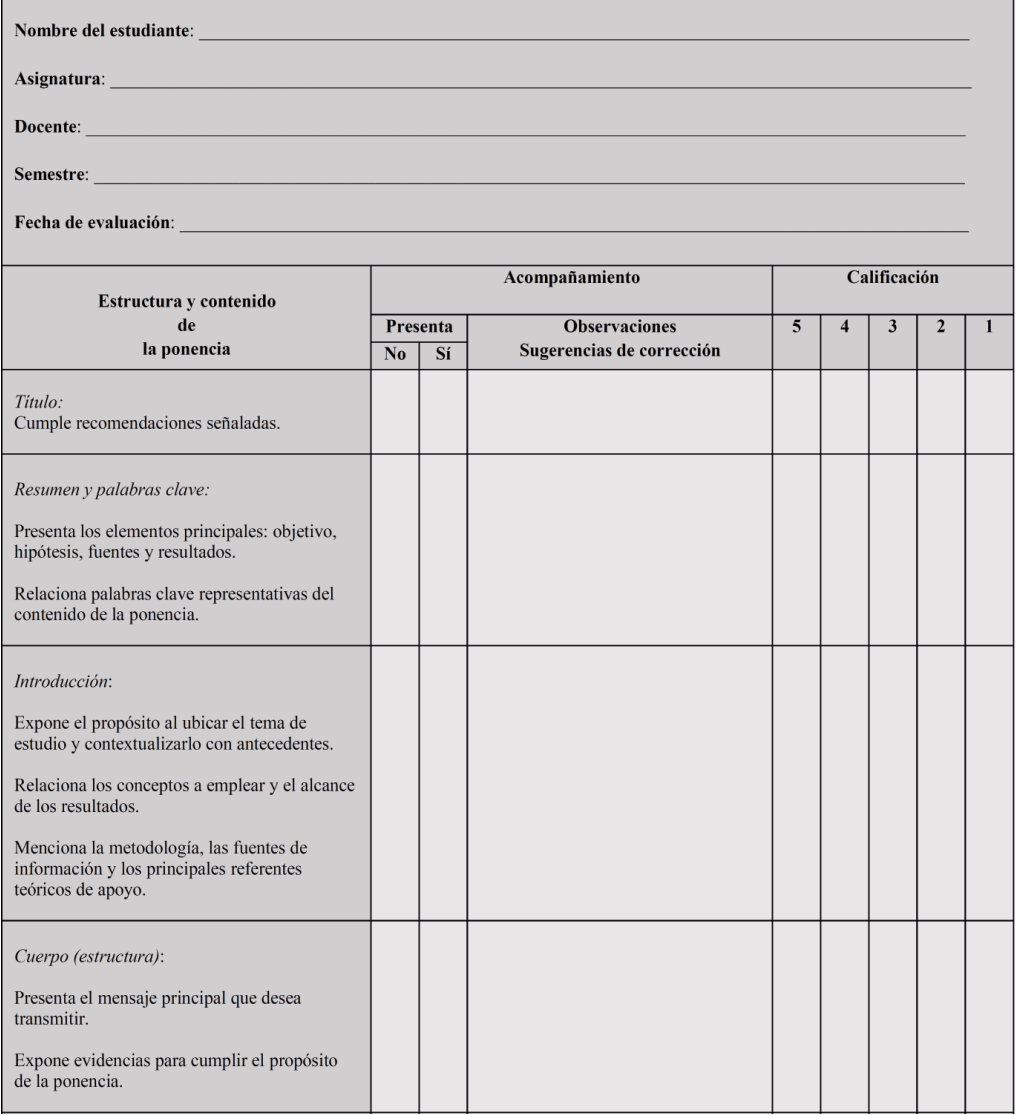




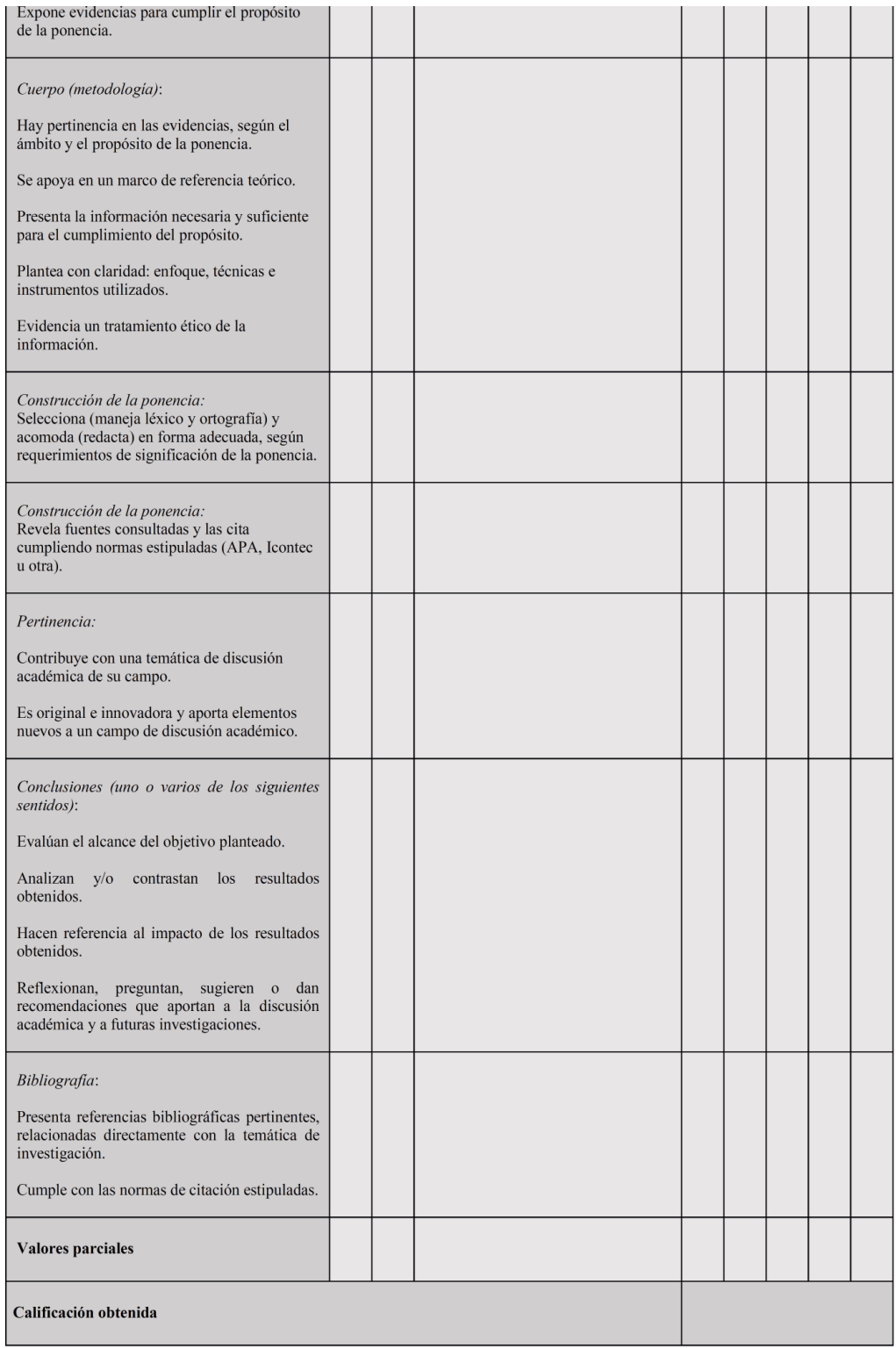

Elaboración propia. 
TABLA NRO. 39. Equivalencias para la valoración de la ponencia.

\begin{tabular}{|c|l|c|c|}
\hline Puntos & \multicolumn{1}{|c|}{$\begin{array}{c}\text { Equivalencias } \\
\text { en términos cualitativos }\end{array}$} & $\begin{array}{c}\text { Escala } \\
\text { puntos obtenidos }\end{array}$ & $\begin{array}{c}\text { Nota } \\
\text { obtenida }\end{array}$ \\
\hline 5 & Excelente: altamente adecuado. & 55 & 5.0 \\
\hline 4 & Bueno: adecuado (algunos errores u omisiones). & 44 & 3.0 \\
\hline 3 & Regular: inadecuado (muchos errores u omisiones). & 33 & 2.0 \\
\hline 2 & $\begin{array}{l}\text { Deficiente: no usa el recurso esperado o todos sus usos } \\
\text { son incorrectos. }\end{array}$ & 22 & 11 \\
\hline 1 & No sabe o no responde. & & 1.0 \\
\hline
\end{tabular}

Elaboración propia.

\subsection{Importancia de la ortografía castellana en los productos de escritura}

La ortografía es uno de los aspectos gráficos en el proceso de escritura, el cual tienen los estudiantes en niveles de formación secundaria, e incluso superior. En los contextos educativos actuales, esta goza de menor atención, gusto y popularidad; salvo en aplicaciones profesionales y en casos personales donde la conciencia sobre su uso se precisa en cada composición escritural. Puesto que la ortografía se ha visto últimamente afectada por un sinnúmero de causas; entre ellas, la irrupción de la tecnología y su rapidez para lograr comunicaciones con mensajes concretos, directos y al instante.

Esta nueva actitud de sentido de muchas personas, entre quienes se halla la población juvenil, reconocida como la más avezada y con mayor comprensión empírica sobre los códigos, los sistemas operativos y las plataformas de interacción contemporáneas, demuestra la ligereza, la reducción y la aceleración con la cual advierten la vida cotidiana. Esta se encuentra relacionada con la escritura híbrida, apocopada, intervenida y transformada - en su forma y en su orden-a través de diferentes dispositivos y redes sociales en los que no interesa el cómo se dice lo que se dice, sino el contacto, el número de likes, la lista de «amigos» y el mensaje llamativo, concreto, directo 
y entendible. De este modo, se fusionan diversos sistemas simbólicos, aunque en este proceder se deforme la gramática de la lengua castellana y su adecuada escritura.

Pero, ¿por qué a pesar de que, en dicha actuación existe un entendimiento implícito, es importante la ortografía de la lengua castellana? ¿Cuál es su nivel de impacto en las comunicaciones escritas que rigen nuestra sociedad, y la formalidad académica y laboral? Para responder a estas preguntas, en el marco de la presente apuesta, se deben recordar las siguientes circunstancias que pueden tomarse como elementos susceptibles de tratamiento didáctico en cualquier nivel de educación. Su reconocimiento, hace decrecer la ingenuidad frente a las palabras y los sentidos sociales, culturales y políticos.

En primer lugar, la ortografía tal como se reconoce desde 1854, cuando se escribió la primera Ortografía de la lengua castellana, es la parte de la Gramática que estudia el uso adecuado al escribir las grafías de la lengua en mención. Esta incluye los acentos, las mayúsculas y los signos auxiliares, para comprenderlos e interpretarlos con arreglo a las intenciones iniciales de producción. En este sentido, para facilitar el aprendizaje y el dominio de la ortografía con el propósito de escribir y comunicar bien, es necesario considerar imprescindible, en todo tipo de escritos, la aplicación de las características que a continuación se describen:

a) La ortografía literal, esto es, aquella que se refiere a la buena escritura de las letras y las grafías, tal y como las registra la RAE en la normatividad actual.

b) La ortografía relacionada con la puntuación, es decir, el adecuado uso de los signos que separan las palabras, frases y oraciones.

c) La ortografía referida a la acentuación, la cual tiene que ver con los acentos tónicos que llevan las distintas palabras del sistema lingüístico castellano. 
Reconocer estas particularidades, ya sea por vía de la lectura consciente o la normatividad pura ${ }^{12}$, hace que la producción textual conserve altos niveles de inteligibilidad formal entre los hablantes de la lengua castellana, es decir, entre participantes de diversas relaciones en la construcción social de la realidad.

Por lo tanto, aunque existen personas que ven innecesaria esta parte de la gramática, es un hecho que se valide la ortografía como asistente inherente del proceso de escritura, así como del proceso de lectura; para descifrar lo escrito es preciso reconocer el sistema lingüístico castellano; y, en él, el sub-sistema ortográfico. Es por eso que se dice que el conocimiento y el dominio de la ortografía aseguran la adecuada comunicación escrita entre los hablantes; al garantizar la precisa creación e interpretación de producciones escritas, se está garantizando implícitamente los sentidos con los que una sociedad crece, se transforma y discute sus problemáticas.

Así pues, no podemos asumir la ortografía como un simple ornamento, refugio estético o malestar necesario; se trata de una condición intrínseca para el total desarrollo de una persona que, en tanto individuo, hace parte de una colectividad, regida por un sistema lingüístico y una gramática. Estos elementos propios, precisos y funcionales responden a una estandarización y se han adecuado al conglomerado social de acuerdo con los cambios del habla histórica (diacronía), de los registros sociales, de las sociedades y sus dinámicas $y$, por su puesto, del sistema ortográfico castellano que ha mutado a través de su acontecer; pero que, al mismo tiempo,

12 Para una amplitud sobre el tema, se recomienda la consulta del texto Ortografía de la lengua española (2010), última de las ortografías académicas publicadas. Esta tiene como objetivo describir el sistema ortográfico de la lengua española y realizar una exposición pormenorizada de las normas que rigen hoy la correcta escritura del español. Esta puede visitarse online a través del siguiente enlace: http://aplica.rae.es/orweb/cgi-bin/buscar.cgi, el cual cuenta con un buscador lematizado de temáticas y subapartados. 
permanece casi estable ${ }^{13}$ en su normatividad para obtener una comprensión sostenible en todos los niveles de crecimiento y estructuración de una sociedad como la colombiana, en donde el castellano posee características especiales en sintonía con la cultura, la idiosincrasia, los dichos y los imaginarios colectivos, dinamizados en la propia lengua.

En segunda instancia, la ortografía se establece como necesaria porque constituye la base del buen sentido para comprender los hechos históricos que han regido, pero también para profundizar sobre sucesos presentes que pueden golpear o lanzar hacia el éxito común. Si se interiorizara la idea de que en las producciones escritas realizadas día tras día se halla el lenguaje humano, como una institución compleja que ha ido agregando múltiples elementos y niveles de estructuración y funcionamiento a través de su historia, se comprenderá el por qué se ha necesitado un conjunto de reglas y de explicaciones, cuyo sustrato ha permitido que en la escritura se pueda evidenciar signos, señales, combinaciones y significados. Este sub-sistema de reglas reconocidas como normas estrictas para la redacción, se ligan indefectiblemente a la comprensión al ser leídas. Total, no se podría advertir un subsistema ortográfico como el que rige la lengua castellana, sin su correlación con el proceso de lectura y su aprehensión significativa. Esto, en una visión didáctico-pedagógica, como la presente, debe aparecer transversal en la manera de invitar a la producción de textos escritos para lograr una redacción apropiada, cuando no pertinente, con los temas y contextos en los que se desarrollen.

Ahora bien, una de las grandes razones por las cuales la normatividad en el sub-sistema ortográfico de la lengua castellana se advierte arbitraria -como lo ha sido desde antaño- es que se hace necesario diferenciar varios sonidos

13 Cabe recordar que esto acontece porque una de las características del signo lingüístico, según Saussure (1945), consiste en su mutabilidad e inmutabilidad a la vez. No se puede cambiar, pero a su vez el influjo del uso y el tiempo terminan modificándolo. Esta es una de las características que desarrolla en sus principios básicos. Para una amplitud sobre el tema, ver su Curso de lingüística general (1945). 
que en la oralidad tienden a confundirse por su realización fonética similar o idéntica. Un ejemplo de ello, sería la adecuada escritura de palabras que contengan los fonemas /c/, /k/, /q/, pues en el nivel fonético responden a un fonema oclusivo velar sordo, que representa una sola realidad posible: /K/. Donde se presenta el primer sonido, ante las vocales $a, o, u$; ante consonante y en posición final de sílaba o palabra (casa, carta, clima, acné, vivac); el segundo sonido, en palabras de origen extranjero (kiosco, kiwi, kurdo, entre otras); y, tercer y último sonido, en un fonema oclusivo velar sordo en palabras (queso, quizás, ataque, practique, entre otras).

Naturalmente, son palabras que al escribirlas requieren de esta distinción gráfica en la lengua castellana; no así en su oralidad por obvias razones sonoras, pues no hay distinción en la palabra casa queriéndola pronunciar con $/ \mathrm{c} / \mathrm{o} / \mathbf{k} /$, o en la palabra kiosco queriéndola pronunciar con $/ \mathbf{k} /$ o /q/. Tales precisiones gráficas, entre muchas otras, son las que tienden a confundir a los niños y jóvenes en su uso a la hora de registrarlas en diferentes tipos de escritos. De ahí que, como la comunicación no se ejerce solamente a través de la oralidad y como la oralidad no es la fiel escritura, la inadecuación, la a-gramaticalidad y la transgresión ortográfica, pululan en las diferentes plataformas y redes sociales; los jóvenes estudiantes, en su gran mayoría, se sienten tentados por la antinorma toda vez que el sistema educativo, en gran parte de su tradición y sus formas de proceder, ha optado por la rigidez; de allí que la oralidad y los sentidos del lenguaje juvenil actual, hayan mutado tal cual a los registros escriturales en redes sociales. No hay distinción alguna, hay un maremágnum de codificaciones y entendimientos haciendo parte de una crisálida pletórica de alegría semiótica y desautomatizaciones lingüísticasmutuas.

No obstante, aunque haya una cierta licencia en las redes sociales y toda suerte de plataformas libres, no es una razón suficiente para bajar la exigencia en los ámbitos formales de educación en los que aún se sigue requiriendo de la formalidad 
gráfica; la misma que sigue respondiendo a los protocolos académicos y a las autoridades universales en materia de aprehensión y circulación social del conocimiento, cuyas bases, siguen siendo fundamentales en los procesos de significación y resignificación de la ciencia en todas las áreas del conocimiento para una actuación profesional y laboral posterior.

Con este panorama, la invitación global en la presente obra se atiene a la idea según la cual, se debe procurar que los aprendices en un contexto de educación formal interioricen que la complejidad del lenguaje en su uso gramatical y ortográfico, debe ser asimilada con seriedad, responsabilidad y funcionalidad, pero también, con divertimiento en los procesos de captura del saber. Pues si no existieran tales reglas, las comunicaciones humanas serían ininteligibles en diversos escenarios sociales. Más aún, si estas reglas no se enseñan con gratitud, decoro y felicidad, no podrá existir una apropiación genuina y extendida desde los primeros niveles educativos; todo saber tiene que ver con la emocionalidad de la enseñanza del sujeto que aprende, pero también con la de quien enseña. Si esto no empieza a operar así en los contextos escolares contemporáneos -impactados por el ágora de la red- la competencia entre los salones físicos y los aprendizajesvirtuales, transgresores y dinámicos, será cada vez más álgida; esto, en tanto la victoria de los segundos puede acercarse cada vez más en detrimento de la existencia de los primeros.

De ahí que, los diferentes tipos de escrito que se han socializado en este libro, tengan que ver irrefutablemente con la adecuación ortográfica en todos sus niveles y con todas sus características. No es pues un intento de molestia por parte del docente que la enseña en sus clases, sino una oportunidad para que el educando crezca en inteligencia, crítica y sabiduría social.Dado que, si advierte de este modo, el espíritu colectivo yla consciencia social que emanan de su uso contextual, tendrán que ver con la manera como se entienden las relaciones culturales, políticas, académicas, religiosas, idiosincráticas, laborales, entre otras. 
Finalmente, se puede señalar que la importancia de la ortografía en los productos escritos es determinante, toda vez que, en una apuesta didáctico-pedagógica, debe plantearse a los educandos como aquel elemento que responde como sistema de verificación del lenguaje. Esto significa que la adecuada transmisión de aquel, obedece a la sumatoria de sus partes y elementos. Los niveles de verificación se deben aprender y enseñar teniendo en cuenta criterios establecidos en lo semántico, pragmático y sintáctico, entendiéndolos como componentes fundamentales de la lengua.

En el primero se debe reconocer y enseñar como todo aquello que es relativo al significado de los mensajes que se transmiten. En el segundo, se debe relacionar con la respuesta que tiene el interlocutor al recibir el mensaje, teniendo en cuenta la interpretación, los usuarios y el contexto de enunciación. Y, en el tercero, como aquel nivel, el cual debe tener en cuenta el orden de las palabras dentro de un mensaje, siendo conscientes de la estructura, el modo en que se combinan y disponen los elementos, los signos de puntuación, entre otros, para de esta forma establecer un sentido claro para el interlocutor (escuchalector).

Así pues, entendiendo la gramática de la lengua castellana en un sentido amplio como todo aquello que interviene desde lo fonético-fonológico, lo morfológico, lo sintáctico, lo semántico, incluso, lo pragmático, se puede decir que es en la coparticipación de estos niveles en los que se halla una lógica para la adecuada utilización del sistema lingüístico castellano en general, y del sub-sistema ortográfico en particular; sobre todo, si se subraya que es en el «criterio sintáctico» en el cual se halla el concepto de Ortografía, ya que son precisamente las convenciones y reglamentos que se han fijado para un sistema de escritura como el del contexto a tratar, por lo que son comúnmente denominadas normas ortográficas -cuyas movilidades pueden ser pocas o muchas- dependiendo de las actualizaciones y los cambios semánticos sucedáneos 
de invenciones múltiples en el desarrollo socio-productivo, en la contemporaneidad de la tecnología y sus proyecciones futuras para interactuar en el mundo -hasta ahora, posibles y comunicadas solamente por la injerencia del lenguaje oral y escrito- y en sus normatividades y convenciones sociales; cuyas dinámicas orto-fonéticas y ortográficas siguen siendo determinantes en los procederes con el sistema lingüístico en los ámbitos cotidianos, sociales, educativos y políticos; en los que la humanidad teje sus productos, cuando no su vida. 


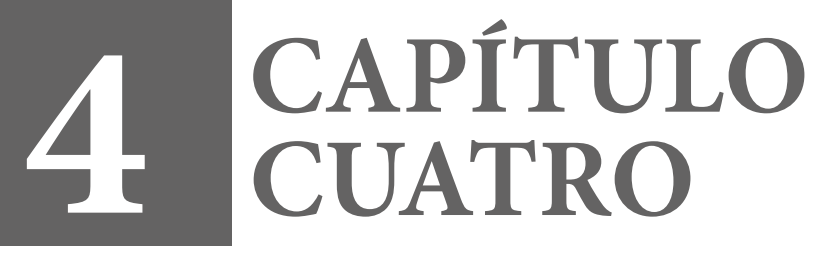




\title{
Procesos y productos de la oralidad
}

\author{
El éxito educativo \\ depende estrechamente de la aptitud \\ para manejar el lenguaje de ideas propio de la educación.
}

Pierre Bourdieu (2008)

En la ontogénesis del lenguaje, hacia los dos años aproximadamente, el lenguaje del niño se torna racional y su pensamiento, verbal (Vigotsky, como se citó en Álvarez, 2010). Esto quiere decir que la palabra materializa el pensamiento y lo traduce con la ayuda de un código que suele ser colectivo. Uno de ellos es la lengua. Según Ortega et al. (2016):

En casi todas las actividades sociales interviene la oralidad: aprendizajes, transacciones, conflictos, acuerdos. De ahí que se tenga la impresión de que la oralidad permite el éxito o determina el fracaso en el desempeño de las acciones interpersonales (Instituto Cervantes, 2008). En la mayoría de actos comunicativos cotidianos media el lenguaje oral... (p. 1).

Y por extensión, en la academia, la oralidad se convierte en un recurso de mucha utilidad para los procesos de enseñanza y aprendizaje.

Los procesos y productos de oralidad se han convertido en un método muy efectivo para transmitir el conocimiento y la circulación de las ideas en la educación superior. La mayor parte de las interacciones comunicativas que ocurren en el aula de clase se realizan a través del discurso oral. El diálogo académico, el debate y la argumentación, sin duda alguna, están mediados siempre por la palabra oral, la cual precede y acompaña todo el proceso de preparación, interpretación y crítica de los textos escritos. No se puede desconocer que la formación en el arte de 
la palabra fue una importante base del currículo universitario desde el surgimiento de las primeras universidades, en la Edad Media, hasta el siglo XIX, cuando la retórica prácticamente se eliminó de los currículos universitarios. La concepción -tan arraigada en la educación- de la presunta superioridad de la palabra escrita sobre la hablada, ha contribuido a desdibujar la función tan importante que tiene el lenguaje oral en la formación universitaria.

Es innegable que existen problemas de rendimiento académico que afectan la calidad educativa en las instituciones de educación superior y en diversos escenarios universitarios a nivel mundial. En este sentido, los esfuerzos académicos encaminados al desarrollo de las competencias comunicativas se hacen perentorios. La oralidad -competencia encargada del discurso hablado- en ocasiones resulta poco trabajada, pues lo más común es encontrar, en las instituciones educativas del nivel superior, proyectos encaminados a la adquisición y desarrollo de las habilidades en comprensión y producción de textos escritos. En relación con esto, e incluyendo también el acto de hablar, Peña (2010) señala:

El ingreso de un estudiante a la universidad se asemeja al del inmigrante que llega por primera vez a un país desconocido. Así como éste tiene que aprender la lengua y las costumbres de sus habitantes para no seguir sintiéndose un extraño, así mismo, si quiere ser parte de la comunidad académica, el estudiante universitario tendrá que pasar por un proceso de iniciación para aprender el idioma, los códigos, los rituales y las formas de hablar, de leer y de escribir propias de esa comunidad (p.20).

Asumir la oralidad como una práctica social y cultural de naturaleza dialógica, implica comprenderla como un acto inagotable que va más allá del intercambio de palabras. Se trata de una construcción de sentido que solo es posible en interacción con otros, es decir, las prácticas de oralidad nacen 
y se construyen en contextos tanto formales (académicos o institucionales), como informales (familiares o sociales); donde los seres humanos interactúan a través de géneros discursivos (orales o escritos), a saber, cuando se conversa o cuando se presenta una conferencia o una ponencia. Incluso, en un seminario-taller se hace uso del lenguaje en clave dialógica. Esto se evidencia cuando Peña (2008) argumenta la importancia del lenguaje en los siguientes términos:

Laimportanciaquetieneellenguajeenlaformaciónuniversitaria puede sintetizarse en sus tres funciones principales: una función comunicativa, en cuanto sirve como instrumento para enseñar, evaluar y hacer público el conocimiento; una función social, como mediador en las relaciones interpersonales, los acuerdos y los proyectos cooperativos; y una función epistémica, como herramienta intelectual y de aprendizaje. El énfasis que se la ha dado a la primera de estas funciones ha hecho que se subestime la importancia que tiene el lenguaje como herramienta psicológica y cultural y como mediación en los procesos de formación propios de la educación superior (p. 1).

En este sentido, el presente escrito propone compartir algunos planteamientos de diferentes autores y desde diversas perspectivas, obtenidos a propósito de la puesta en marcha de la «Estrategia de acompañamiento a los estudiantes de Licenciatura de la Facultad de Ciencias de la Educación de la Universidad TecnológicadePereira, en materia decompetencias comunicativas», específicamente en la línea de acción que demanda el diseño de documentos de apoyo, para que los docentes acompañen algunos procesos y productos de oralidad de sus estudiantes, lo cual, se espera contribuya a ampliar su capital cultural, pues al planear y ejecutar intervenciones orales de diferente índole, deberán consultar un sinnúmero de obras que propiciarán el contacto con otro tipo de géneros, de prácticas textuales y de formas de hablar y de escribir, indispensables para la comprensión de diferentes formas de pensar y de sentir, en sus entornos locales y globales. 
Así mismo, la potencialidad de estos procesos y productos permite a los actores involucrados desde la emisión y desde la recepción, adquirir, desarrollar y compartir conocimientos, tanto en el ámbito formal (laboral y académico), como en el informal (como lo son sus entornos: familiar, social y cultural). De esta manera, se constituyen procesos y productos con la posibilidad de trascender la palabra, acceder a un público más amplio y convertir las experiencias colectivas en espacios para la lúdica, la creatividad y la recreación; donde se fortalece una visión integral del desarrollo humano, visto este como un promotor y conductor de mejora a nivel personal, a nivel social y a nivel académico, en el ámbito universitario.

Se abordarán entonces en este capítulo algunas formas de intervención individual y grupal que se suscitan en el aula de clase. Este abordaje, a manera de documentos de apoyo para los docentes que decidan implementarlos en su clase y que requieran una herramienta teórico-práctica, aplicable en los procesos de enseñanza y aprendizaje de estas modalidades de intervención oral: conversatorio, exposición, mesa redonda y debate; estructuradas como técnicas participativas, con una concepción metodológica dialéctica, que apunta a una construcción colectiva del conocimiento y, a la vez, posibilita un escenario grupal de reflexión y discusión a través del cual los participantes pueden crear y recrear su experiencia y sus conocimientos.

\subsection{Conversatorio}

\subsubsection{Concepto}

Se encuentran varias definiciones sobre conversatorio. El Diccionario de la Real Academia Española -DRAE- (2019) lo define de acuerdo a su uso en varios países de América, como: «Reunión concertada para tratar un tema». Y Muñoz et al. (2011) afirman que: 
Es una reunión concertada para tratar un tema, en la cual participan personas versadas en la materia. La reflexión sistemática sobre esta forma de interacción grupal se ha desarrollado desde la simple conversación o charla, diálogo, coloquio, conferencia, hasta devenir en un nuevo concepto que resume los demás (p. 68).

El conversatorio como estrategia de comunicación oral hace un intercambio informal y sencillo, pero también un evento serio en sus propósitos, pensado en su preparación y ordenado en su realización, ya que no surge espontáneamente, sino como resultado de una actividad en el salón de clase para que los estudiantes inicien un intercambio de opiniones y pareceres con el resto del grupo interesado en un acontecimiento o asunto de actualidad y con un grado de homogeneidad similar. Es una posibilidad de evaluación pedagógica donde la iniciativa de quienes intervienen se puede combinar con los conocimientos previos y permitir, de ese modo, un avance significativo en el aprendizaje.

Entre las ventajas de un conversatorio, se tiene que es una herramienta que procura el intercambio de experiencias y la discusión de temas en un ambiente informal y divertido, de mayor confianza que el debate, en el sentido de que las confrontaciones se hacen de una manera más amigable.

\subsubsection{Procedimiento para su realización}

\subsubsection{Participantes (quiénes)}

El conversatorio se lleva a cabo por parte de un grupo, donde se destacan previamente, uno o varios expositores centrales. En el caso de un solo expositor central no es necesario, aunque puede acordarse, un coordinador o moderador del evento. En el caso de varios expositores, sí es conveniente. 


\subsubsection{Metodología (cómo)}

El expositor o los expositores centrales deben preparar con debida anticipación no sólo el tema, sino también el ambiente, las ayudas audiovisuales y la invitación a los participantes con el objetivo de que estos también puedan pensar cómo hacer sus aportes. Si solo hay un exponente, este se puede autopresentar o puede ser presentado por un moderador, quien se requiere cuando hay varios individuos que intervienen centralmente.

\subsubsection{Expositor o coordinador}

Incluso, puede iniciar su participación haciendo una pregunta al auditorio. El tono empleado por el expositor o expositores y los demás participantes es informal y de doble vía, por lo cual, los unos como los otros pueden interrumpir para hacer preguntas o aclaraciones.

\subsubsection{Intervenciones}

Se hace uso del buen humor. Del mismo modo, el expositor y el coordinador pueden desplazarse por el estrado o la sala si lo consideran adecuado. No es un evento para confrontaciones conflictivas entre los interlocutores. Las elocuciones deben estar dirigidas a convencer y, en ese sentido, apoyarse en argumentos y datos coherentes. El coordinador o el expositor si solo hay uno, procuran hacer una síntesis de los acuerdos y conclusiones.

\subsubsection{Contexto (dónde, cuándo y cuánto)}

Es una interacción del aula de clase, pero en ocasiones, es necesario acudir a salas de conferencias, incluso con instrumentos de amplificación. El conversatorio es útil cuando se pretende ayudar a los estudiantes a perfeccionarsu expresión oral y la exposición de sus posiciones ante un público conocido, sin necesidad de llegar a conclusiones definitivas, pues lo 
que interesa, sobremanera, es recabar opiniones y constatar las diferentes posturas ante un asunto o acontecimiento. La actividad debe tener corta duración - no mayor de una horay es adecuado cuando se trata de grupos pequeños donde se facilitala participación del público.

\subsubsection{Aspectos clave durante un conversatorio}

Las recomendaciones que se pueden ofrecer para esta modalidad de intervención oral pueden resumirse en las siguientes:

- La conversación como el género primario protolenguaje denominado así por Bajtín (1979), se encamina a provocar en los interlocutores un cambio de actitud según las intenciones comunicativas en una situación singular. El conversatorio se desliza a partir de recursos de la lengua denominados deícticos o señalamientos que se constituyen bidireccionales; en tal sentido, hay que saber el momento y las circunstancias precisas para lograr pertinencia en la progresión temática abordada en lo hablado.

- En el momento de tomar la palabra, de adecuarla al contexto enunciativo, lo prioritario reside en la claridad, pertinencia y contundencia para lograr el impacto y/o efecto deseado. Solo en la oportunidad de la voz en el acto, en la escena discursiva, las intenciones pueden considerarse exitosas o infortunadas; todo depende de la forma de enlazar ideas y precisar a los otros en mi discurso para poseerlos, asirlos, cuando no convencerlos de que la propia perspectiva, sea constatativa o realizativa, constituye un momento irremplazable para situarse en el discurso, en lo conversado.

- El propósito del conversatorio es configurar una serie de ideas, conceptos, nociones, entre otros, en un escenario específico, según los géneros discursivos y las 
intenciones comunicativas tematizadas. La doxa, más que un ejercicio de verdad, de Aletheia, en el sentido inicial platónico-aristotélico, es un ejercicio de defensa y subjetividad; pues la objetividad en sí misma no sería más que la sumatoria de las visiones heteróclitas y no la exclusividad de las ideas que se lanzan inmutables, únicas y para siempre. En este sentido la impronta discursiva hace parte de la visión de una persona al concebir el mundo, de aquí que sea relevante tener en cuenta la diversidad de visiones y la posibilidad de la comunicación ya sea en el disenso o en el consenso.

- El conversatorio se convierte en una actividad de tolerancia y de aceptación de múltiples diferencias entre una misma especie. Son las diferencias las que finalmente construyen las identidades. En la palabra del otro me reconozco y viceversa; total, somos en la medida en que otros nos reconocen en la palabra y a su vez los reconocemos en la nuestra. Solo existimos en la medida en que la dimensión lingüística humana se desplaza entre uno y otro hablante habilitado social y cognitivamente para interactuar y reconocerse como un ser social. Quien inicia una conversación inaugura también un espacio para la sorpresa y para el asombro en múltiples direcciones donde el lenguaje se convierte en un juego en el que aceptamos o no sus reglas.

- En la conversación se involucran aspectos no lingüísticos que también hablan. Hay que cuidar de ellos, sobre todo, cuando el lenguaje corporal - los gestos, las miradas, las posturas- y el lenguaje vocal -las entonaciones, entre otros- ubican al interlocutor en terrenos cómodos o incómodos. Así, el lenguaje en sentido amplio simboliza el mundo con apoyo del lenguaje en sentido estricto, que se encarga de gramaticalizarlo y apalabrarlo. En ello, los contextos físico, histórico, empírico, natural, cognitivo e ideativo, entre otros, son fundamentales para lograr el éxito en la actividad comunicativa. 


\subsubsection{Evaluación}

Lo dicho aquí sobre el CONVERSATORio se incluye en la rejilla presentada en la TABLA NRO. 40. Su valoración desde lo cualitativo busca ofrecer la oportunidad de registrar observaciones y sugerencias de ajuste; desde lo cuantitativo, constituye un instrumento para brindar una calificación (nota) que dé cuenta de la calidad del trabajo que se revisa. Para determinar si se califica uno u otro valor, pueden consultarse las respectivas equivalencias en la TABLA NRO. 41.

TABLA NRO. 40. Rejilla para la valoración del conversatorio.

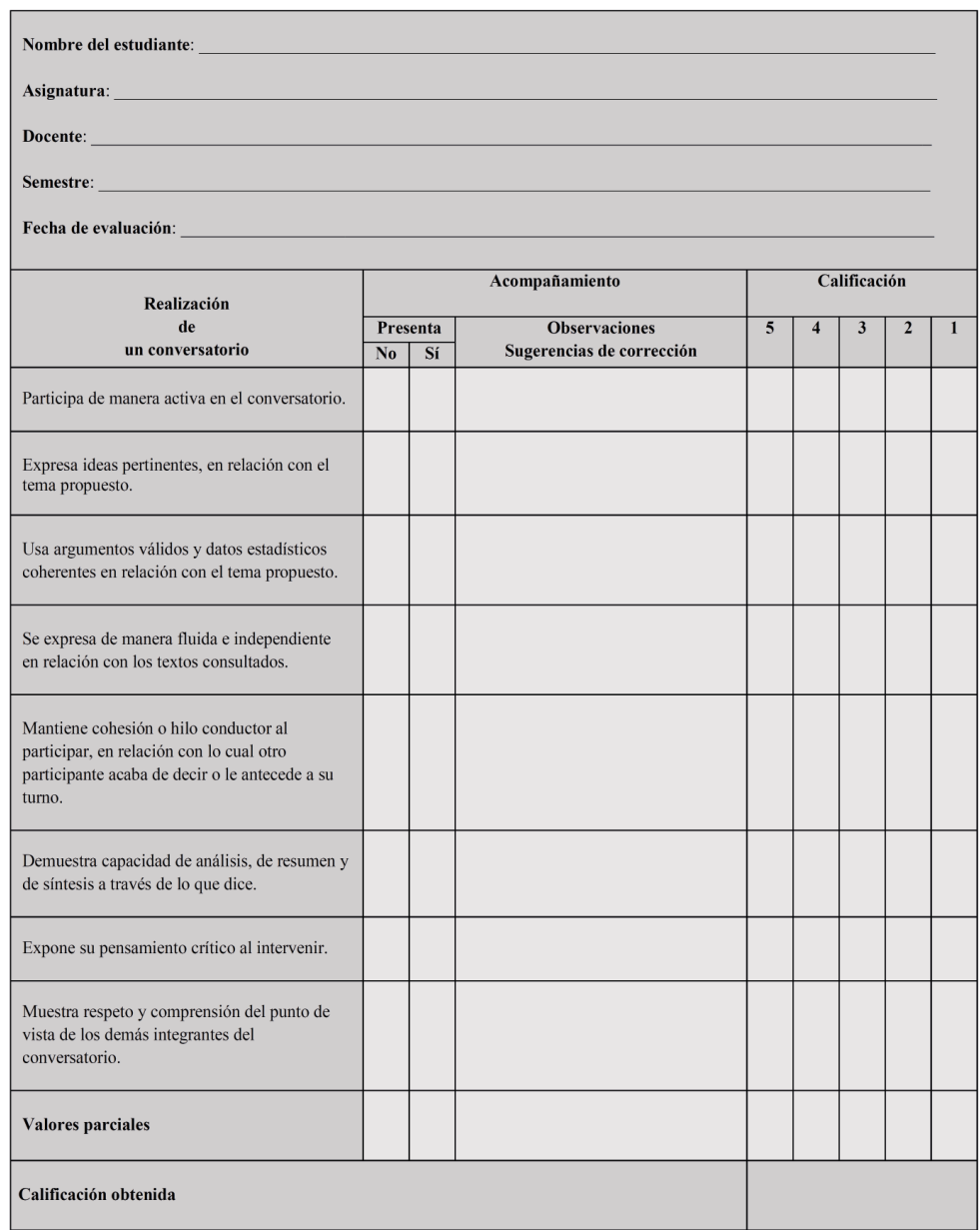

Elaboración propia. 
TABLA NRO. 41. Equivalencias para la valoración del conversatorio.

\begin{tabular}{|c|l|c|c|}
\hline Puntos & \multicolumn{1}{|c|}{$\begin{array}{c}\text { Equivalencias } \\
\text { en términos cualitativos }\end{array}$} & $\begin{array}{c}\text { Escala } \\
\text { puntos obtenidos }\end{array}$ & $\begin{array}{c}\text { Nota } \\
\text { obtenida }\end{array}$ \\
\hline 5 & Excelente: altamente adecuado. & 40 & 5.0 \\
\hline 4 & Bueno: adecuado (algunos errores u omisiones). & 32 & 3.0 \\
\hline 3 & Regular: inadecuado (muchos errores u omisiones). & 24 & 2.0 \\
\hline 2 & $\begin{array}{l}\text { Deficiente: no usa el recurso esperado o todos sus usos } \\
\text { son incorrectos. }\end{array}$ & 16 & 1.0 \\
\hline 1 & No sabe o no responde. & 8 & \\
\hline
\end{tabular}

Elaboración propia.

\subsection{Exposición}

\subsubsection{Concepto}

La exposición oral consiste en hablar en público sobre un tema determinado, consiste en explicar un tema o una idea con la intención de informar.

Agudelo et al. (2014) la consideran como «un recurso importantepara compartir y adquirir o acceder al conocimiento y para desarrollar algunas destrezas sociales» (p. 106), donde el expositor, quien se dirige a un público idealmente atento a sus palabras, debe:

Combinar una serie de destrezas, las cuales se adquieren con la práctica y la crítica constante a su propio proceso formativo. [...] un expositor entrenado desarrolla habilidades para estructurar las ideas que debe enunciar, para establecer un contacto comunicativo adecuado con los grupos en que se desempeña a través de los diferentes sistemas de signos disponibles (verbales y no verbales) y para hacer verosímil su discurso e incluso para resultar persuasivo, cuando así lo requiera (p. 106).

En la exposición, alguien que ha preparado de manera concienzuda un tema se presenta ante otras personas para 
divulgar lo que sabe, provisto además de cierta capacidad comunicativa que haga más eficaz su intervención.

Para realizar una buena exposición oral se debe tener en cuenta muchos factores que intervienen en su realización, así lo afirma Jaramillo (s.f.), dividiéndola en tres grandes grupos, como se muestra a continuación.

\subsubsection{Factores personales}

Para realizar una buena exposición oral es necesario hablar ante un auditorio, pero no de cualquier forma, sino más bien haciendo uso del cuidado o del tener siempre en cuenta algunos aspectos de la persona como:

- Superar la timidez ${ }^{14}$.

- Adaptarse a los intereses y conocimientos del público.

- Ser claros: hablar alto y lentamente; y, además, precisar ideas.

- Transmitir sinceridad y convencimiento de lo que se expone.

- Mostrarse naturales y sencillos en los gestos y en lo que se dice, huir de la pedantería y de la monotonía.

- No demostrar demasiado nerviosismo; además, se necesita un buen contacto visual con todo el público.

- Elaborar un plan para la exposición.

14 Experimentar miedo es una reacción normal en el $90 \%$ de los oradores novatos. Antes de comenzar a hablar, la inseguridad o timidez aceleran el corazón: la sangre ruboriza las mejillas, las rodillas tiemblan, la voz no quiere salir. Es difícil dar consejos para este momento. Quizá baste pensar que, tras las primeras frases, se recupera la tranquilidad. Se debe olvidar el miedo realizando otras cosas: revisar mentalmente algunos puntos de la exposición, revisar la sala o los materiales que se van a emplear, saludar las personas conocidas que llegan a escuchar. Evitar los tics que aumentan el nerviosismo, respirar profundamente varias veces y sonreír para entablar un contacto afectivo con el auditorio. 


\subsubsection{Factores temáticos}

Además de tener en cuenta el control al hablar ante un público, se debe recordar que la finalidad es entregar un mensaje, por lo que este debe ser expuesto en el mayor orden y claridad posibles.

- Preparación del material.

- Preparación de las instalaciones físicas.

- Preparación psicológica.

- Audiencia.

- Presentación personal.

- Puntualidad.

- Programa de la exposición oral.

- Elaboración de un guion.

- Preparación de la intervención.

\subsubsection{Factores formales}

La presentación personal debe ser intachable, se debe llegar puntualmente y en el día asignado. La vestimenta debe ser formal, tanto como el lenguaje a utilizar. No olvidar:

- Ajustarse a los tiempos asignados.

- No leer en ningún caso, excepto alguna tarjeta con palabras claves.

- Que la voz se escuche en todo el auditorio, sin apuros y con una buena entonación. 
Ahora bien, para tener mayor información sobre cómo hablar en público, se puede remitir a libros impresos que hablan al respecto, $o$ acudir a la virtualidad ${ }^{15}$.

\subsubsection{Procedimiento para su realización}

La exposición, como una de las modalidades de intervención oral, individual o grupal, se puede concebir y realizar con base en tres etapas como lo muestra la FIgURA NRO. 23.

FIGURA NRO. 23. Etapas de realización de la exposición.
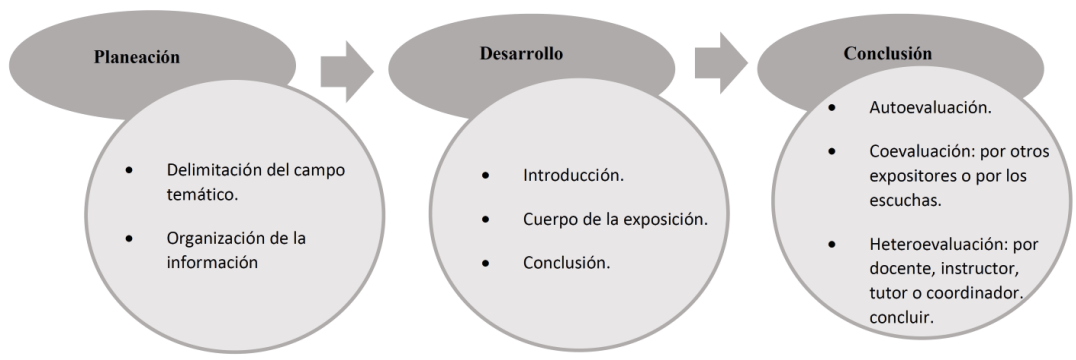

Basada en Agudelo et al. (2014, pp. 107-111).

\subsubsection{Planeación}

Aunque se domine el tema con alguna solvencia, es deber de todo expositor cumplir con unos pasos previos, como se refiere en las líneas siguientes:

Consulta acerca de lo que se quiere exponer y organización de la información: Según el grado de conocimiento, se puede empezar por enciclopedias y obras generales, para luego emplear obras especializadas. En este momento, es factible recurrir a libros, revistas, periódicos, películas, internet y material multimedia en general. Luego se procede a la selección y depuración para solo usar lo más importante, de acuerdo con el interés de quien expone y, por supuesto, de lo que espera el público.

15 Para ampliar información puede remitirse al siguiente enlace: http://www.youtube.com/ watch?v=6rCkhhtFfoI 
En esta modalidad de intervención oral, no basta con seleccionar y organizar la información según los intereses del hablante, es necesario consultar y prever los intereses y demandas del auditorio. El abordaje del tema, su profundidad y rigor, su tono y léxico, no dependen exclusivamente del nivel cultural del expositor, sino también del tipo de público que se tendrá en frente. Es el momento de seleccionar la información que se va a divulgar.

Elaboración de un bosquejo de lo que será la exposición: Se trata de un esquema muy personal sobre cómo se va a desarrollar el tema consultado para hacerlo llegar al público. También es importante elaborar fichas mnemotécnicas que permitan condensar la información necesaria para el desarrollo de la exposición. Éstas le permitirán al expositor consignar un esquema del desarrollo del contenido de la exposición, para garantizar el orden y coherencia en el tratamiento de las ideas, y registrar datos (nombres, términos técnicos, fechas, cifras precisas, entre otros) de difícil evocación, sin depender exclusivamente de su buenamemoria.

Ayudas audiovisuales y recursos didácticos: En este momento de la planeación, se procede a hacer la selección y preparación de las ayudas audiovisuales y de otros recursos didácticos (folletos, talleres, resúmenes, información adicional, imágenes, entre otros), si se consideran necesarios. Puede elegirse alguno o algunos de los que se presentan en la TABLA NRO. 42.

TABLA NRO. 42. Ayudas audiovisuales: recomendaciones para su diseño y uso.

\begin{tabular}{|l|}
\hline AYUDAS AUDIOVISUALES \\
\hline Tablero, papelógrafo y cartelera \\
\hline $\begin{array}{l}\text { Descripción: } \\
\text { Son recursos tradicionales que se utilizan para presentar información de manera esquemática, alrededor de la cual, el expositor hará su } \\
\text { intervención; por lo tanto se pueden emplear opciones como: el mapa mental, el mapa conceptual y el cuadro sinóptico entre otros } \\
\text { organizadores gráficos. Con estas ayudas se le facilita al público la toma de apuntes y la asimilación del mensaje. }\end{array}$ \\
\hline
\end{tabular}


Recomendaciones para su diseño y uso:

- Utilice letra legible y de igual tamaño y estilo

- Escriba la letra de un tamaño acorde con la cantidad de asistentes y la distancia a la cual se encuentran.

- Evite el uso indiscriminado de letras mayúsculas y minúsculas, y la utilización de mayúscula sostenida en todo el material.

- Garantice la calidad ortográfica del texto.

- $\quad$ Evite el uso de prosa extensa.

- Use márgenes e interlineado adecuados, para evitar que las palabras luzcan apeñuscadas.

- Presente los materiales con estética y pulcritud: sin tachones en la escritura, sin dobleces en el material, sin renglones desviados y sin manchas o suciedades.

- Disponga de manera armónica y equilibrada los elementos que componen el material, equilibrio entre texto e imagen, tanto en tamaño como en cantidad.

- Trabaje con colores complementarios para no caer en combinaciones incómodas o que impidan la visualización del texto, no utilice colores fosforescentes o tenues sobre fondos claros, prefiera los contrastes fondo-figura (por ejemplo, colores fuertes sobre fondos claros).

Estas recomendaciones también son válidas para elaborar carteles, los cuales se usan para fijar información, bien sea que ayude a ambientar un recinto donde se hace la intervención oral, o para dar información puntual acerca de la realización de un evento.

\section{Diapositivas}

Descripción:

Actualmente hay un uso generalizado de programas informáticos, lo cual incluye la presentación de diapositivas a través del videoproyector. Estas son un apoyo para el expositor, por eso de ninguna manera remplazan el amplio conocimiento del tema que este posee

Recomendaciones para su diseño y uso

- Utilice letra con un tamaño promedio de 18 a 20 puntos para garantizar su fácil visualización por parte del público.

- Use letra tipo Times New Roman o con serifa (con gancho en las bajantes o subientes de cada letra), porque son más legibles y más descansadas para el lector.

- Emplee un máximo de dos tipos de letra para una presentación.

- Elija colores neutros o colores complementarios. No se recomienda el uso de letra clara sobre fondos claros.

- Utilice fondos de un solo color, en particular en el sitio sobre el cual se va a ubicar el texto, para favorecer su visualización y lectura.

- Evite letras blancas sobre fondo negro o cualquier otro color oscuro, contraste agradable a primera vista, pero que tiende a cansar mucho a los lectores.

- Sea conciso empleando la menor cantidad posible de texto, no más de 40050 palabras por párrafo, sin incluir más de un párrafo por diapositiva.

- Agilice la presentación al combinar texto e imagen en una misma diapositiva.

- Ubique el videoproyector a 2,5 metros o más de la pared, para que la proyección permita que el público visualice fácilmente el contenido.

- Emplee un promedio de 25 diapositivas para una intervención planeada de una hora. Aunque sobre la cantidad de diapositivas a emplear no hay un consenso.

- Absténgase de leer a los asistentes la totalidad de los contenidos alli escritos, salvo en el caso en que se desee enfatizar para que no pase sin la debida atención del público.

- Evite usar efectos demasiado llamativos que distraigan al público, o efectos que prolongan la presentación y el proceso de lectura de la información de la diapositiva.

- Deje expuesta cada diapositiva durante 2 o 3 minutos, para que el lector la lea con suficiencia y atienda su discurso.

Grabaciones en audio o video

\section{Descripción:}

Su uso es cada vez más extendido apelando a recursos como el internet, con el fin de aprovechar las posibilidades o alcances multimedia de esta plataforma

Recomendaciones para su diseño y uso:

- Seleccione materiales con información pertinente, necesaria y suficiente según sus objetivos al exponer y el tipo de público, para no someterlo a extensas presentaciones.

- Verifique previamente la compatibilidad de los soportes y herramientas a utilizar

Material icónico, simbólico o indicativo

Descripción:

Son objetos que el expositor juzga necesarios para apoyar la exposición, bien sea porque reproduzcan en escalas menores y de semejanza aquello de lo cual se habla: material icónico (mapas, fotografias y caricaturas); porque lo representen en forma arbitraria: material simbólico (banderas, escudos, logos, entre otros); o porque indican o señalan de qué se está hablando: material índice o indicativo (medicamentos, si se habla de enfermedades; vasijas de barro y material óseo, si se habla de hallazgos o arqueología, entre otros).

\section{Elaboración propia.}


No obstante haber elegido una o varias de las ayudas (expuestas la TABLA NRO. 42), para utilizar en el momento del desarrollo de la exposición, se sugiere tener previsto un plan de emergencia (plan B o plan alternativo) que salve la situación en caso de presentarse dificultades con los soportes que permiten suimplementación.

\subsubsection{Desarrollo}

Durante la exposición, se prevén tres momentos delimitados como se detalla a continuación:

Introducción: Es una parte de la exposición que se emite de manera espontánea. En ella se integra el tema del cual se hablará, la importancia que tiene dicho tema, el sector del público al cual le puede interesar más, el objetivo que persigue el expositor, el proceso que se cumplió para preparar la exposición -incluyendo las fuentes consultadas (bibliográficas, testimoniales, situacionales) $-\mathrm{y}$, las temáticas, contenidos $\mathrm{o}$ subtemas que se abordarán. Todo esto para motivar al público, orientarlo frente a los alcances que tendrá dicha exposición y darle un parte de confiabilidad en lo que se diga.

En esta instancia se sugiere que el expositor:

- Apele a los recursos necesarios y suficientes para motivar al público y atraer su atención frente al tema propuesto.

- Proyecte al público su nivel de identificación y convencimiento con lo que esté diciendo.

- Asuma la introducción de manera espontánea, diferenciándola en todo caso, del tratamiento dado a las temáticas que estructuran el desarrollo de la exposición.

- Predetermine la distribución del tiempo en su exposición, ajustándose al tiempo total asignado para ella. 
- Distribuya los impresos en este momento de la exposición, únicamente si están previstos como guía de la misma. Si tienen otros fines es preferible entregarlos al finalizar la intervención.

Cuerpo de la exposición: Es el momento en el cual el expositor desarrolla el tema según el plan previsto y anunciado en la introducción mediante el uso de ayudas elaboradas previamente. Para tener éxito en la exposición es necesario que el tratamiento del tema se caracterice por su claridad, orden, precisión, concisión y sencillez. Todo esto se puede lograr en la medida en que el expositor:

- Demuestre suficiencia en el manejo del tema.

- Anuncie el paso de un subtema a otro.

- Evite la lectura generalizada de documentos que convierten la exposición en una actividad de lectura oral.

- Lea solo la información que demande alto grado de precisión, como el caso de las citas textuales.

- Porte fichas mnemotécnicas en lugar del material consultado previamente.

- Recuerde que las ayudas no son algo decorativo en esta intervención; hay que utilizarlas.

- Garantice que las ayudas utilizadas aporten a la claridad y la precisión en el desarrollo del tema, y en la toma de apuntes por parte del público.

- Sea conciso, haga uso racional del tiempo asignado para esta intervención oral. 
- Reciba, preferiblemente al final de este momento, los aportes del auditorio (preguntas, observaciones $y$ sugerencias).

- Reúna los aportes del auditorio y resuélvalos en una sola intervención.

Conclusiones: Se hace un balance de los aspectos más importantes abordados y las implicaciones de estos, para así garantizar que la forma como se presente este balance, resulte coherente con el objetivo que sirvió de guía para la exposición.

En esta parte de la exposición es posible también recurrir a estrategias discursivas como la síntesis, el llamado a la reflexión $\mathrm{y}$ el ofrecimiento de pautas para el manejo de situaciones vinculadas con el tema tratado; enunciando las conclusiones de manera sucinta, pues las explicaciones, los ejemplos, las implicaciones, entre otros desarrollos de asuntos centrales, debieron abordarse en el cuerpo de la exposición.

Puede acudirse a una clasificación específica de conclusiones para no limitar esta parte de la exposición. Al respecto, Agudelo et al. (2014), retomando a Shardakov, señalan la retrospección, proyección y comparación, para esta modalidad de intervención oral.

Como puede observarse, la introducción y las conclusiones en esta modalidad de intervención oral son muestra del dominio que se tiene de una información y, por ende, del proceso que se tuvo en su preparación. Son constructos personales que se constituyen en el valor agregado de la exposición, pues bien es sabido que hay gran cantidad de fuentes donde se puede ir a consultar una información sin necesidad de la mediación llamada «expositor» en este caso. Por eso, dichas partes en la exposición se realizan en forma espontánea, y llevan el sello propio del expositor. 


\subsubsection{Evaluación}

Esta última etapa tiene como propósito abrir un espacio para retroalimentar el proceso, a través de la identificación de los aspectos positivos y de aquellos que son susceptibles de ser mejorados. Este momento puede ser abordado, cuando se asumen diferentes posibilidades asociadas a los conceptos de autoevaluación, coevaluación y heteroevaluación, de acuerdo con las condiciones del momento o las necesidades que allí se perciban.

Siempre para el expositor resulta útil, a través de un ejercicio de autoevaluación y una vez terminada su labor, echar una mirada hacia atrás con el propósito de valorar los aciertos para así poderlos potenciar y replicar en otras oportunidades; igualmente, es importante para identificar los errores que se pudieran haber cometido con el fin de enmendarlos, evitando su aparición en futuras exposiciones. Esta mirada, la cual realiza el propio expositor sobre su trabajo frente a un auditorio, puede verse complementada y enriquecida al consultar el criterio de otros integrantes del grupo expositor o del grupo que cumple con el rol de escucha; esto mediante el procedimiento de la coevaluación.

Finalmente, y de manera especial, si la exposición hace parte de una clase, resulta fundamental la valoración que de la práctica realice quien coordina o dirige la actividad (docente, instructor, tutor, entre otras denominaciones). Tanto para este caso, como para los que pudieran implicar instancias de autoevaluación o coevaluación, resulta recomendable, para ejecutar la valoración, tener en cuenta aspectos como los siguientes: expresión corporal, manejo de la voz, manejo del tema o contenido y uso de las ayudas audiovisuales.

\subsubsection{Presentación (momentos de realización)}

En aras de lograr brevedad, claridad y orden en la exposición oral, como palabras claves dentro de esta modalidad de 
intervención, se citan las reglas de oro a considerar, aportadas por Jaramillo (s.f.):

\subsubsection{En la parte introductoria}

Demostrar una actitud de seguridad y confianza con la forma de pararse adelante, de mirar y de decir las primeras palabras. Tomar un poco de tiempo antes de comenzar, todo debe estar en orden para que solo haya que concentrarse en el público y en lo que se desea exponer. No olvidar usar expresiones tales como: "me propongo exponer», "el objetivo de este», «muchos piensan que», "deseo manifestar mi», «nos dirigimos a ustedes para», «acabo de presenciar un hecho que», "sobre el tema de», «es un hecho que», "quisiera comenzar mi exposición diciendo que», «en primer lugar», «en primer término», "para empezar».

\subsubsection{En el desarrollo (o cuerpo de la exposición)}

Es importante comenzar con una idea general de lo que se va a decir. Se debe empezar con las ideas más generales para luego llegar a las ideas más específicas. El tema debe desarrollarse al momento de argumentar cada una de las ideas expuestas, esto, haciendo uso de variada documentación como citas, ejemplos, anécdotas, soportes audiovisuales, entre otras. Se debe desarrollar el tema de una forma llamativa y nunca monótona. No olvidar usar expresiones tales como: «a continuación», «enseguida», «en segundo lugar», «además», «también», «hay que añadir que», "del mismo modo», «igualmente», «asimismo», «en otras palabras», «es decir».

\subsubsection{En la conclusión}

Se debe planificar bien la conclusión, no improvisarla. Avisar cuando se va a llegar a este apartado, hacer saber al público que se acerca el final de la disertación por medio de expresiones lingüísticas que expliciten que el discurso se va a terminar; en ellas se pueden encontrar: «en resumen», «resumiendo», «en síntesis», «en pocas palabras», «en suma». 


\subsubsection{Evaluación}

Lo dicho aquí sobre la Exposición, se incluye en la rejilla presentada enla TABLA NRO. 43. Su valoración desdelo cualitativo busca ofrecer la oportunidad de registrar observaciones y sugerencias de ajuste; desde lo cuantitativo, constituye un instrumento para brindar una calificación (nota) que dé cuenta de la calidad del trabajo que se revisa. Para determinar si se califica uno u otro valor, pueden consultarse las respectivas equivalencias en la TABLA NRO. 44.

TABLA NRO. 43. Rejilla para la valoración de la exposición.

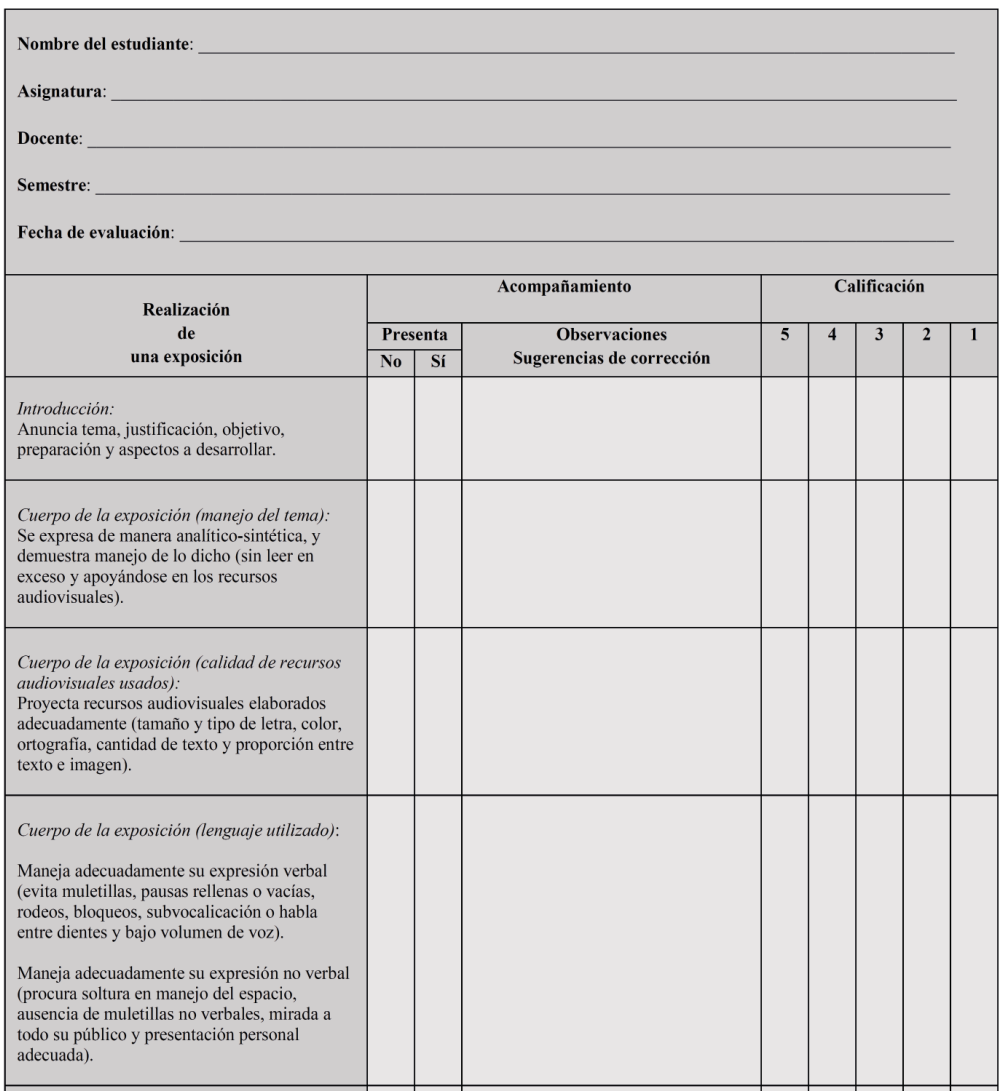




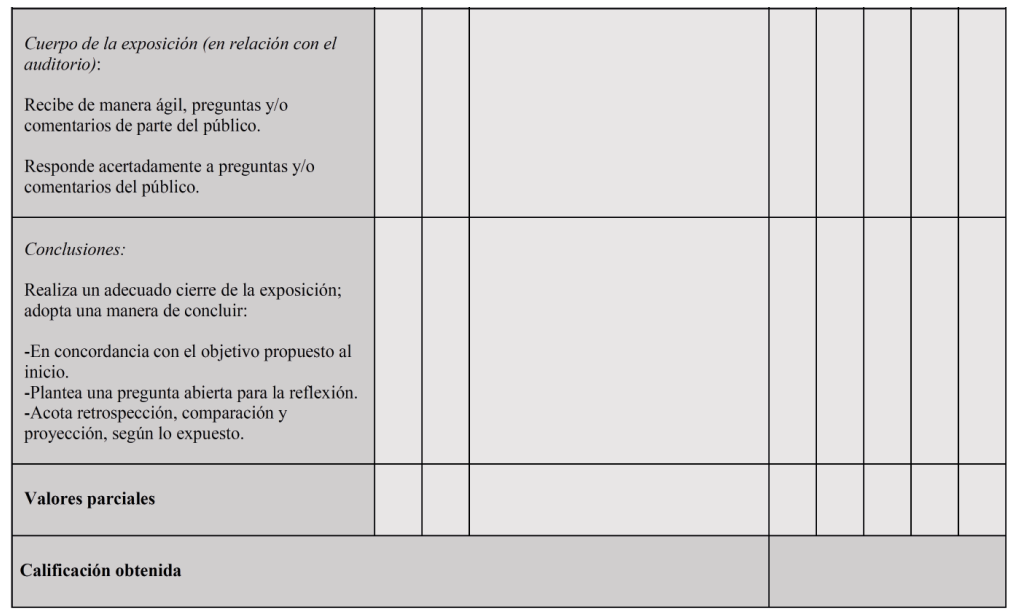

Elaboración propia.

TABLA NRO. 44. Equivalencias para la valoración de la exposición.

\begin{tabular}{|c|l|c|c|}
\hline Puntos & \multicolumn{1}{|c|}{$\begin{array}{c}\text { Equivalencias } \\
\text { en términos cualitativos }\end{array}$} & $\begin{array}{c}\text { Escala } \\
\text { puntos obtenidos }\end{array}$ & $\begin{array}{c}\text { Nota } \\
\text { obtenida }\end{array}$ \\
\hline 5 & Excelente: altamente adecuado. & 30 & 5.0 \\
\hline 4 & Bueno: adecuado (algunos errores u omisiones. & 24 & 4.0 \\
\hline 3 & Regular: inadecuado (muchos errores u omisiones). & 18 & 3.0 \\
\hline 2 & $\begin{array}{l}\text { Deficiente: no usa el recurso esperado o todos sus usos } \\
\text { son incorrectos. }\end{array}$ & 12 & 1.0 \\
\hline 1 & No sabe o no responde. & 6 & 1.0 \\
\hline
\end{tabular}

Elaboración propia.

\subsection{Mesa redonda}

\subsubsection{Concepto}

La mesa redonda es la presentación de diferentes puntos de vista, no necesariamente contradictorios, acerca de un tema determinado, ante un público y con la ayuda de un moderador. A diferencia del debate, en la mesa redonda se busca fomentar el diálogo entre los participantes para desarrollar el tema desde diferentes áreas o puntos de vista. Por ello, este tipo de género oral es el ideal cuando se quiere abordar una temática a fondo sin caer necesariamente en el esquema del debate. De manera 
general, se utiliza como complemento de congresos o ciclos de conferencias, con la intención de profundizar en temas específicos.

Su nombre obedece precisamente, a que en ella no existen jerarquías, distinciones, ni privilegios; sino que, todos los participantes están sujetos a las mismas reglas y ostentan los mismos derechos. Es un acto comunicativo de exposición oral, conducido por un moderador e integrado por un grupo de participantes o expositores, que pueden o no contar con la presencia de un público. En ella, los contribuyentes han decidido previamente el tema sobre el que van a debatir, y se han puesto de acuerdo con relación a las reglas bajo las cuales se va a desarrollar el evento, donde por lo general, estipulan el tiempo establecido para cada intervención, el orden de las participaciones, y el respeto al derecho del otro de expresar su punto de vista sin ser interrumpido o incomodado.

Ahora bien, según Agudelo et al. (2014), los objetivos de una Mesa redonda son:

- Ofrecer diferentes puntos de vista con un nivel de información variado y amplio.

- Proporcionar hechos y opiniones sobre problemas y temas de discusión.

- Facilitar el interés hacia determinadas cuestiones, motivar al grupo a la investigación o a la acción, hacia la búsqueda de soluciones.

- Representar a un grupo heterogéneo de personas que, por ser demasiado numeroso, no puede intervenir directamente en la discusión (pp. 115-116). 


\subsubsection{Procedimiento para su realización}

El papel de cada integrante de la mesa redonda está previamente definido por el tipo de dinámica, así:

\subsubsection{El moderador o coordinador}

Será el encargado de la presentación de los participantes, la introducción, la conducción de la mesa redonda (dirigir las intervenciones del público, siendo imparcial, esto es, sin mostrar favorecimiento o rechazo hacia ningún participante de la mesa, y velar por el cumplimiento de los tiempos), las conclusiones de allí emanadas, y el cierre de la misma; no sin antes encargarse de establecer un orden para las preguntas que puedan surgir en el público.

\subsubsection{Los participantes}

Se encargarán de preparar previamente su intervención. Son quienes deben pensar, planear y dirigir sus ideas hacia la audiencia; aportar información verificable que sustente el punto de vista adoptado y respetar las reglas asignadas por el moderador.

\subsubsection{La audiencia}

Es el público que acude y participa en este ejercicio. Tras la discusión, en la mayoría de los casos, los asistentes tienen la posibilidad de plantear dudas y compartir sus comentarios, lo cual seguramente, complementa el tema tratado. Como regla general, ningún miembro del público debe interrumpir hasta que se les dé la palabra.

\subsubsection{La preparación}

Reconocidas las funciones de los actores de la mesa redonda, es necesario mencionar algunas acciones puntuales que pueden llevarse a cabo como preparatorias de esta forma de intervención 
oral. Agudelo et al. (2014) hacen alusión a la preparación de la mesa redonda señalando acciones muy puntuales:

- Motivar y determinar con precisión el tema a tratar.

- Invitar a las personas que expondrán.

- Preparar el lugar con afiches, letreros, recortes, revistas y todo lo que tenga relación con el tema a tratar.

- Efectuar una reunión previa a la mesa redonda para coordinar participantes, temas y subtemas, desarrollo y tiempos.

\subsubsection{Principales características}

Para que una mesa redonda se convierta en un espacio de aprendizaje, debe tener, además del cabal cumplimiento de los roles de sus integrantes, las siguientes características:

\subsubsection{Tema}

Previo a su inicio, los integrantes de la mesa redonda tienen conocimiento del tema que se va a desarrollar durante la misma. Cada uno ha preparado su punto de vista en torno a una misma temática.

\subsubsection{Objetivo}

Este puede ser una pregunta a resolver o un tema a conocer a profundidad.

\subsubsection{Ni jerarquías ni diferencias}

Cada participante desarrolla su opinión, así como su punto de vista acerca de determinada materia. Aquí no hay espacio para las distinciones ni para los privilegios. 


\subsubsection{Intervenciones}

La mesa redonda no sería tal, si dentro de su realización no se efectuaran las distintas intervenciones que se requieren por parte de sus participantes. Sobre ellas se construye el transcurso de la misma y son realizadas de acuerdo a un turno que el coordinador ha otorgado a cada participante. Esto genera nuevas posiciones y nutre el intercambio de ideas, con nuevos aportes.

\subsubsection{Reglas}

Cuenta con tiempo de inicio, en el cual los participantes ocuparán su lugar a la hora acordada, deben estar listos con su intervención y saben, de antemano, que pueden escuchar otras posiciones distintas a las suyas, sin que esto sea motivo de disputa.

\subsubsection{Preguntas}

La mesa redonda tiene una sección muy particular y que sin duda caracteriza su gran éxito. Esta sección son las preguntas y están a cargo del público presente, quienes, durante el transcurso de la mesa redonda, tuvieron la oportunidad de escuchar las distintas intervenciones. Con ellas, el tema se complementa, adquiere nuevas posiciones y garantiza que el tema sea cubierto en su totalidad.

\subsubsection{Conclusiones}

Son las principales ideas que van surgiendo de la mesa redonda. Pueden ser consignadas por una persona que ha sido previamente seleccionada o, por cada uno de los participantes. Al final, son recolectadas y socializadas, con el fin de dar el cierre al ejercicio académico. 
No obstante, dadas las anteriores características, se ofrecen, a continuación, recomendaciones puntuales sobre ellas, la manera de empleo y las advertencias; todo esto gracias a Hernández y Ospina (como se citó en Agudelo et al., 2014).

\subsubsection{Características dinámicas}

- La atmósfera puede ser informal o formal.

- El interés del auditorio aumenta si se hacen evidentes las diferencias de opinión, la presentación activa y la competencia entre losparticipantes.

- Es un método útil para definir puntos de acuerdo y campos de desacuerdo.

- Reparte la responsabilidad, requiere previa reflexión y recolección de datos por parte de los integrantes.

- Estimula la investigación de los integrantes.

\subsubsection{Recomendaciones al grupo organizador del encuentro}

- Tener claramente definidos los objetivos de la reunión.

- Cerciorarse de seleccionar un tema oportuno y significativo.

- Seleccionar de manera cuidadosa a los integrantes de la mesa redonda. En particular, elegir personas que tengan puntos de vista diversos y que manifiesten interés en expresarlos ante un grupo.

- Elegir un moderador que invite al respeto. 
- Seleccionar con suficiente anticipación a los integrantes de la mesa redonda y al moderador, pues así tendrán un tiempo prudente para estudiar e investigar el tema.

- Sentar a los integrantes de la mesa redonda de manera estratégica, para que puedan verse entre sí y que el público los observe.

\subsubsection{Sugerencias dirigidas a los integrantes de la mesa redonda}

- Preparar el material y organizar las consideraciones sobre la discusión.

- Escuchar con atención los comentarios de los otros integrantes de la mesa y esforzarse por comprender los puntos de vista y lo que hay detrás de ellos.

- Esperar el momento oportuno para expresar su punto de vista y tratar sólo del asunto que se está hablando. Mantener la discusión en tono informal, tipo conversación.

- Circunscribir los comentarios a cortos periodos de tiempo (dos o tres minutos).

\subsubsection{Advertencias finales}

- El éxito depende de la elección cuidadosa del moderador y de los integrantes de la mesa redonda.

- La intervención no debe ser monopolizada por uno de los miembros.

- No debe haber discusión preliminar sobre el tema por parte de los integrantes de la mesa redonda. Si esto se realiza, la discusión pública a menudo se transforma en un anticlímax trillado y teatral. 
- Las mesas redondas con una duración inferior a treinta minutos raras veces tienen éxito, pero se debe concluir mientras el interés del público se mantiene en alto.

\subsubsection{Presentación (momentos de realización)}

La mesa redonda se caracteriza por estar dividida en cuatro partes que la componen. Estas son:

\subsubsection{La introducción}

Momento en que el coordinador se presenta, presenta a los participantes, y da a conocer el tema, dentro de una introducción, desde la cual motive a los asistentes y participantes.

\subsubsection{El cuerpo de la discusión o intervención}

Momento en que los participantes intervienen con sus diversos, pero respetables puntos de vista.

\subsubsection{La sesión de preguntas y respuestas}

Dirigida también por el coordinador y en donde tiene gran participación el público.

\subsubsection{Las conclusiones}

Las cuales permiten redondear y dar por finalizado el tema que fue motivo de discusión.

\subsubsection{Evaluación}

Lo dicho en las anteriores líneas sobre MESA REDONDA, se incluye en la rejilla que se presenta en la TABLA NRO. $45 . \mathrm{Su}$ valoración desde lo cualitativo busca ofrecer la oportunidad de registrar observaciones y sugerencias de ajuste; desde lo cuantitativo, constituye un instrumento para brindar una 
calificación (nota) que dé cuenta de la calidad del trabajo que se revisa. Para determinar si se califica uno u otro valor, pueden consultarse las respectivas equivalencias en la TABLA NRO. 46.

TABLA NRO. 45. Rejilla para la valoración de la mesa redonda.

\begin{tabular}{|c|c|c|c|c|c|c|c|c|}
\hline \multicolumn{9}{|l|}{$\begin{array}{l}\text { Nombre del estudiante: } \\
\text { Asignatura: } \\
\text { Docente: } \\
\text { Semestre: } \\
\text { Fecha de evaluación: }\end{array}$} \\
\hline \multirow{3}{*}{$\begin{array}{c}\text { Realización } \\
\text { de } \\
\text { una mesa redonda }\end{array}$} & \multicolumn{3}{|r|}{ Acompañamiento } & \multicolumn{5}{|c|}{ Calificación } \\
\hline & \multicolumn{2}{|c|}{ Presenta } & \multirow{2}{*}{$\begin{array}{c}\text { Observaciones } \\
\text { Sugerencias de corrección } \\
\end{array}$} & \multirow[t]{2}{*}{5} & \multirow[t]{2}{*}{4} & \multirow[t]{2}{*}{3} & \multirow[t]{2}{*}{2} & \multirow[t]{2}{*}{1} \\
\hline & & Sí & & & & & & \\
\hline Participa activamente en la mesa redonda. & & & & & & & & \\
\hline $\begin{array}{l}\text { Expresa ideas pertinentes, en relación con el } \\
\text { tema propuesto. }\end{array}$ & & & & & & & & \\
\hline $\begin{array}{l}\text { Desarrolla su punto de vista acerca del tema } \\
\text { señalado }\end{array}$ & & & & & & & & \\
\hline $\begin{array}{l}\text { Se expresa con fluidez e independencia en } \\
\text { relación con los textos consultados. }\end{array}$ & & & & & & & & \\
\hline $\begin{array}{l}\text { Mantiene cohesión o hilo conductor al } \\
\text { participar, en relación con lo que dijo quien le } \\
\text { antecedió su turno. }\end{array}$ & & & & & & & & \\
\hline $\begin{array}{l}\text { Genera, a través de su participación, nuevas } \\
\text { posiciones y aportes, nutriendo el intercambio } \\
\text { de ideas. }\end{array}$ & & & & & & & & \\
\hline $\begin{array}{l}\text { Demuestra capacidad de escucha frente a } \\
\text { posiciones distintas a las suyas, y las asume con } \\
\text { respeto y comprensión. }\end{array}$ & & & & & & & & \\
\hline $\begin{array}{l}\text { Formula preguntas que complementan el tema y } \\
\text { permiten adquirir nuevas posiciones que } \\
\text { garanticen su total comprensión. }\end{array}$ & & & & & & & & \\
\hline Valores parciales & & & & & & & & \\
\hline Calificación obtenida & & & & & & & & \\
\hline
\end{tabular}

Elaboración propia. 
TABLA NRO. 46. Equivalencias para la valoración de la mesa redonda.

\begin{tabular}{|c|l|c|c|}
\hline \multirow{2}{*}{ Puntos } & \multicolumn{1}{|c|}{$\begin{array}{c}\text { Equivalencias } \\
\text { en términos cualitativos }\end{array}$} & $\begin{array}{c}\text { Escala } \\
\text { puntos obtenidos }\end{array}$ & $\begin{array}{c}\text { Nota } \\
\text { obtenida }\end{array}$ \\
\hline 5 & Excelente: altamente adecuado. & 40 & 5.0 \\
\hline 4 & Bueno: adecuado (algunos errores u omisiones). & 32 & 3.0 \\
\hline 3 & Regular: inadecuado (muchos errores u omisiones). & 24 & 2.0 \\
\hline 2 & $\begin{array}{l}\text { Deficiente: no usa el recurso esperado o todos sus usos } \\
\text { son incorrectos. }\end{array}$ & 16 & 3.0 \\
\hline 1 & No sabe o no responde. & 8 & 1.0 \\
\hline
\end{tabular}

Elaboración propia.

\subsection{El debate}

\subsubsection{Concepto}

De acuerdo con la definición más universal sobre lo que constituye un debate, su puesta en escena discursiva compromete un acto propio de la comunicación, consistente en el desarrollo y discusión acerca de un tema polémico entre dos personas o grupos. Su naturaleza es argumentativa y está guiado por un moderador. En él, los participantes deben sostener sus mejores ideas y defenderlas con argumentos que traten de persuadir o de convencer. Así, la calidad y solidez de los argumentos, permiten no solo el triunfo, sino también el refuerzo y el fomento de aprendizajes en torno a la pluralidad de temas en el ámbito pedagógico y comunicativo.

En virtud de lo anterior, desde la conformación de la Antigua Grecia y su filosofía, el debate ha permanecido incólume en el desarrollo de las sociedades y sus gestas. Los presocráticos y su filosofía iniciática así lo demostraron; aunque fueron discursos y debates que no pasaron a la historia oficial de la filosofía occidental, sus debates configuraron gran parte de lo que hoy se reconoce como evidente en el mundo de la vida y su devenir. Por el contrario, los debates que sí tuvieron eco en la tradición filosófica, marcaron a partir de los contrapunteos sostenidos por Sócrates, Platón y Aristóteles, las vías predilectas para 
el sostenimiento del logos, la razón y la instrumentalización del conocimiento moderno. De aquí que, indistinto de las vías privilegiadas, el debate siga constituyendo en el ámbito académico y público, uno de los mejores métodos para argumentar a favor o en contra sobre temas de interés formativo y socio-político (Serna, 2011).

De acuerdo con Sánchez (2007), se hace necesario clarificar inicialmente qué no es un debate para plantear una definición precisa acerca de lo que realmente es. Fundamentado en los postulados de Cattani (2003), este autor distingue entre términos similares que pueden pasar por sinónimos de la palabra debate, pero no lo son. Los términos a los que se refiere son los siguientes:

Diálogo: Hablar con alguien o razonar junto a otro interlocutor con la intención de buscar alguna verdad.

Discusión: Contraste pacífico de ideas.

Polémica: Un debate con ciertos tintes de agresividad, el cual no es violento ni maneja irreductibilidad.

Controversia: Una divergencia de opiniones continua, encendida y referida a intereses.

Disputa: Es el debate doctrinal.

Diatriba: Debate áspero, polémico, teórico, erudito o filosófico (Cattani, 2003).

Una vez hecha esta distinción, Cattani (como se citó en Sánchez, 2007), refiere que un debate, en el marco de una perspectiva pedagógica y formativa, debe definirse como:

Una competición (un reto, un desafío) entre dos antagonistas, en los que, a diferencia de lo que ocurre en una simple discusión, existe una tercera parte (un juez, un auditorio) cuya 
aprobación buscan los dos contendientes. Se puede debatir, incluso sobre cuestiones que se consideran imposibles de resolver con el objetivo de persuadir a otros (p. 67).

En esta definición, se destaca la tercera parte: juez o auditorio y su aprobación. Según el autor, en una discusión cotidiana sobre cualquier tema se intenta convencer al interlocutor. No ocurre así en un debate académico en el que se debe convencer al juez o jurado. En el debate se distingue la presencia de una tercera parte con un poder decisorio sobre el resultado a favor o en contra del tema o los temas debatidos. En el ámbito académico, el método debe contener y contemplar las visiones de los dos actores: docente y estudiante, con sus precisas tareas y responsabilidades pedagógicas.

\subsubsection{Procedimiento para su realización}

Los pasos que puede cumplir el docente para persuadir a los estudiantes, y de esta forma lograr que participen en un debate, son los siguientes:

\subsubsection{Escoger un tema de debate}

Según Sánchez (2007), la elección de un tema no resulta tan difícil si persigue cumplir con los objetivos de la asignatura o del momento en el que se encuentra. Si el objetivo es sensibilizar hacia la asignatura como tal, el autor señala que se puede debatir sobre la necesidad de estudiar la lectura y la escritura o sobre la utilidad de la oralidad en la vida cotidiana de modo que el alumno se entere reflexiva y profundamente de la importancia de la materia. $\mathrm{Si}$, por el contrario, el objetivo es la impartición de conocimientos declarativos quizá sea conveniente debatir, por ejemplo, sobre las consecuencias negativas del descubrimiento de América a fin de que el alumno conozca los hechos de la colonización. 
Según el autor, en cualquier caso, el profesor puede percibir algunas señales que puede interpretar como favorables para sugerir un tema de debate que resulte interesante para el alumnado. Por ejemplo, donde hay una duda o surge una pregunta o una discusión espontánea, ahí hay un posible tema de debate. Siempre que el conjunto de educandos tenga una duda, no tanto sobre el proceso sino relativas a la moralidad o veracidad de un hecho histórico o un descubrimiento científico, por ejemplo. El tema, aunque depende de los objetivos del profesor (sensibilizar, enseñar a pensar o a practicar habilidades de comunicación), puede ser especialmente útil consensuar algunas posibles temáticas entre el profesor y los estudiantes. Las propuestas de estos últimos pueden ayudar a conocer cuáles son sus preocupaciones. La técnica del debate es ajustable a prácticamente todas las materias, pues de cualquier área de conocimientos surgen diferencias y visiones enfrentadas.

\subsubsection{Redactar la proposición}

La proposición o resolución del debate es el tema, de manera acotada y redactada, de modo que, es debatible; pues, de acuerdo con Sánchez (2007), se supone que cumple las once características que proponen González et al. (2016), a saber:

- ¿Interesante para el debatiente?

- ¿Actual? (o actualizado).

- ¿Oportuno?

- ¿Se puede cubrir en el tiempo disponible?

- ¿Adecuado a una presentación oral?

- ¿Provoca desacuerdo?

- ¿Es clara o ambigua? 
- ¿Se puede apoyar en evidencias?

- ¿Merece la pena discutirlo?

- ¿Se puede comparar? (Valores).

- ¿Son dos cuestiones o una? (p. 95).

El profesor puede elaborar una lista de comprobación de las características modelo de una resolución, evaluar estas al debatir y seleccionar las más adecuadas. El docente debe formular la proposición para el debate, acotándola según sus intereses pedagógicos y disciplinarios en los ámbitos y niveles de educación particulares.

\subsubsection{Decidir y explicar el formato de debate, según los objetivos docentes}

Sánchez (2007) propone que una vez que se haya acotado la resolución de debate, se procede a escoger el formato que mejor se ajuste a los objetivos docentes. Esto es, el formato ha de adecuarse a las capacidades del estudiante y a los objetivos del profesor. Sea el formato que sea, este último puede diseñar uno propio, pero ha de cumplir siempre las siguientes características, según Cirlin (como se citó en Sánchez, 2007):

- El mismo tiempo para las dos posturas.

- Afirmativo o a favor siempre primero y último, pues es el que tiene la carga de la prueba.

- Conocido por todos los participantes con antelación suficiente.

- Tiempo total de treinta a noventa minutos. En el caso de esta última norma la experiencia indica que para estudiantes de Educación Primaria Obligatoria se 
pueden llevar a cabo formatos con menos de treinta minutos. La configuración del debate inferior a la media hora permite que los alumnos desarrollen argumentaciones sólidas preparadas con antelación.

A continuación, se exponen algunos formatos de debate empleados en competiciones de debate en universidad. No obstante, el docente que decida poner en marcha formatos de debate propios ha de tener en cuenta que debe englobar las siguientes partes:

- Exposición inicial o discurso constructivo (Tesis): los argumentos.

- Refutación (Antítesis): ataques, defensas relativas a exposición inicial.

- Conclusión (Síntesis): conclusiones a favor o en contra del por qué la posición en el debate es la que debe secundar el jurado.

\subsubsection{Diseñar el acta de los jueces}

El acta en esta perspectiva se entiende como una herramienta esencial para poder emitir un veredicto objetivo, más allá de dar ganador al equipo que simplemente haya causado una mejor impresión. Es la herramienta del juez o jurado que va a dar como ganador a un equipo u otro.

En este modelo se presenta un tipo de acta empleada en competiciones de debate universitario. No obstante, el profesor, una vez más, puede diseñar un acta (rejilla evaluativa) donde refleje sus objetivos docentes. Así, en función de loque considere como prioritario, se tendrá en cuenta ciertos elementos antes que otros; o bien, puede estimar todos los elementos. Sin embargo, puede dar más peso a unos elementos frente a otros. 
El docente considerará qué criterios debe reflejar el acta en función de si se persigue una formación en habilidades o, por el contrario, el acopio de determinados conocimientos. En el modelo presentado, el procedimiento es sencillo pues el juez ha de marcar con una $\mathbf{X}$ si se ha cumplido o no tal o cual criterio. Después sumará el número total de $\mathbf{X}$ que ha cumplido cada equipo, y así, el que más sume será el ganador del debate para ese juez. No obstante, este modelo puede adaptarse a criterio y finalidad de la clase y el tema.

\subsubsection{Reunirse con los equipos y orientarles}

El docente debería instruir, en lo posible en cuanto a tiempo y conocimientos, en algunos mínimos sobre comunicación oral en cuanto a forma y fondo, argumentación y debate para poder participar en la actividad con ciertas garantías. Al igual que para un trabajo escrito el profesor debería orientar cómo han de citar y estructurar un trabajo.

\subsubsection{Escoger jurado (implicar estudiantes)}

El debate ha de ser juzgado y para ello, según Sánchez (2007), se puede implicar a otros profesores o a estudiantes de la propia aula. Se está ante una oportunidad singular de vincular al educando en la marcha de la asignatura. Una ocasión de conceder responsabilidad al estudiante desmotivado. Puede ocurrir que el docente derive la responsabilidad de juzgar a los alumnos en exclusiva y este permanecer como observador crítico. El jurado ha de cumplir una serie derequisitos:

- Siempre un número impar para evitar empates.

- Ponderar la nota de cada juez, según si el profesor es juez o no lo es, y si quiere que su voto sea de calidad. 


\subsubsection{Protocolo del debate}

Con la intención de implicar al máximo número posible de estudiantes en el aula, se debe organizar un cierto protocolo conocido por toda la clase. Así, el protocolo normal de un debate puede ser:

- Presentación del tema, los debatientes y el jurado, bien por parte de uno de los jueces o bien por parte de uno de los alumnos que haga las veces de «maestro de ceremonias».

- Ejecución del debate según el formato acordado.

- Cierre del debate por parte del alumno encargado del protocolo.

- Retirada del jurado para deliberar mientras el resto del aula formula preguntas a los debatientes.

- Comunicación del veredicto del jurado y realización de comentarios a los debatientes.

\subsubsection{Juzgar el debate}

La labor de los jueces se estructura en un antes, un durante y un después del debate. Los jueces, durante el debate, han de tener en cuenta qué hace cada participante y qué no ha hecho. Así, el juez ha de observar y tomar notas de cada discurso de los alumnos. Tras el debate han de rellenar el acta o plantilla de valoración de debate y emitir un veredicto. Uno de los jueces puede controlar el tiempo.

\subsubsection{Comentarios personales y grupales}

Es una de las más enriquecedoras de todo el proceso. El hecho de que unos estudiantes, los jueces, sepan comunicar sus críticas de manera constructiva y valiente; y el hecho de 
que otros, los debatientes, sepan asumir dichas críticas, es un elemento de formación humana propio del debate. Tras el debate, el jurado y en especial el profesor, han de emitir comentarios que ayudarán a que el alumno crezca, tanto en el ámbito de la asignatura, como en sus capacidades intelectuales. Es el momento de hacer una serie de comentarios que motiven al estudiante, pero sin que nunca se pierda la realidad. Un elemento de dureza en todo este proceso es que dichos comentarios se hacen en público - frente al aula- de manera tal que el emisor de los comentarios debe guardar las formas y ser asertivo en sus críticas. El profesor y juez o no del debate, también deben emitir su valoración con la intención de dar su visto favorable o desfavorable. Los comentarios del profesor han de ser todos aquellos que no hayan formulado el resto de los alumnos los cuales hayan participado como jueces. Puede resultar conveniente emplear una sesión entera para este paso. Los jueces que emitan sus comentarios, a través de un portavoz, deben comentar aspectos positivos y mejorables de cada equipo en los siguientes aspectos:

- Fondo: evidencias, razonamientos, entre otros.

- Forma interna: orden, estructura, lenguaje propio.

- Forma externa: comunicación no verbal (kinésica y proxémica).

- Labor de equipo: comunicación interna.

- Capacidad dialéctica: ataque y defensa de argumentos.

\subsubsection{Asignar la calificación}

Del profesor depende que el debate influya en la calificación del estudiante. La experiencia dice que se valora lo que se evalúa. Se pueden tener en cuenta diferentes opciones a la hora de manejar la evaluación de un debate: 
- La nota del profesor a cada equipo: De la misma que ponemos una nota a un trabajo escrito, no hay razón para no poner una nota al trabajo oral realizado por un equipo de debatientes.

- La del jurado. Se puede tomar la nota media del jurado. Incluso se puede suprimir la más alta y la más baja si se quiere evitar posibles rencillas entre los estudiantes.

- Un plus para el equipo ganador: Además de la nota que tengan por sus trabajos habituales, la nota de debate puede suponer un plus.

- El voto del resto de los estudiantes: Es recomendable que, al terminar el debate, los educandos participantes respondan a las preguntas del resto de alumnos. También se puede contar tanto las preguntas de unos como las respuestas de los otros. La nota de debate se puede tener en lugar de o además de las notas de exámenes, trabajos y demás.

\subsubsection{Pasos a seguir para la realización del debate}

Hablando del debate en el ámbito académico, según la perspectiva de Sánchez (2007), el estudiante, por su parte es el que debería tener más trabajo que el profesor universitario a la hora de participar en un debate. Todos los pasos se deberían trabajar en equipo a excepción del paso que implica un trabajo de redacción, por cuanto es más personal. Así, este autor señala quelos pasos que debe seguir un estudiante son:

\subsubsection{Analizar la proposición}

Análisis es lo contrario de síntesis. El alumno debe analizar y ver los diferentes significados e interpretaciones de la proposición y de sus términos. En este proceso de análisis se ve obligado a definir, bien de manera propia o bien mediante la consulta de diccionarios. En cuanto al logro pedagógico de esta etapa, el estudiante se verá obligado a ser conceptualmente riguroso, y a interpretar y entender lo que posteriormente se debatirá. 


\subsubsection{Pensar argumentos}

El estudiante, tras haber comprendido las acepciones de la pregunta, debe pensar en argumentos que afirmen o nieguen la proposición. Así, debería volcar todo lo que sabe, piensa, duda o simplemente desconoce sobre el tema de debate. En dicha tempestadde ideas caben:

- Posibles argumentos.

- Sus propias ideas sobre la materia de debate.

- Tempestad de ideas.

- Pensar en dónde investigar.

\subsubsection{Investigar}

En esta parte el profesor debe descubrir al educando qué herramientas y qué métodos están disponibles para buscar evidencias y entender ciertos procesos y conceptos. En cualquier caso, la idea consiste en aprovisionarse de evidencias. Los objetivos pedagógicos de esta fase son:

- Que el estudiante salga del libro de texto.

- Que entre en la biblioteca.

- Que relacione lo cotidiano con lo que lee (logro del conocimiento significativo).

\subsubsection{Preparar argumentación a favor o en contra (fondo del discurso)}

El estudiante ha de tener en cuenta los posibles argumentos tanto a favor como en contra. La razón de considerar ambas posturas es que una será necesaria para defender su posición 
y el hecho de considerar la otra, reside en que se debe tener en cuenta que hay que saber atacarla. Los pasos de esta fase son:

- Construcción de una tesis; una gran respuesta a la pregunta de debate.

- Elaboración de argumentos según la estructura ARE:

Afirmación: pensados.

Razonamiento: explicados.

Evidencia: apoyados en evidencias escogidas.

En esta etapa el educando aprende a razonar y a relacionar el conocimiento con ciertos fines, en este caso persuasivos. También, percibe un valor en el conocimiento y este deja de ser, para él y no para el docente, inerte y llega a ser significativo.

\subsubsection{Repartir posiciones}

Una vez trabajado el fondo argumentativo, el equipo debe asignar posiciones en los turnos de exposición, refutación o conclusión. Depende del formato de debate escogido, pero en función de las capacidades de cada cual, los alumnos deberían tener en cuenta que hay estudiantes más rápidos en la respuesta (refutadores) y otros que son más elocuentes y persuasivos (más aptos para las exposiciones). Se trata de asignar a cada jugador su posición en el campo y sus funciones, por utilizar un símil deportivo. Para cada turno de debate el alumno ha de prepararse para:

- Exposición inicial: exponer los argumentos.

- Refutación: atacar argumentos contrarios y defender los propios.

- Reforzar con nuevas evidencias o argumentos sus exposiciones. 
- Preparar posibles preguntas a los debatientes del equipo contrario.

- Conclusión: llegar a una conclusión tras haber tenido en cuenta lo acontecido durante el debate.

Con esta fase se desarrolla la capacidad de pensamiento abstracto en el alumno y la capacidad de pensar en posibles argumentaciones contrarias, lo cual desarrolla la capacidad de pensamiento estratégico y empático.

\subsubsection{Redactar forma interna}

Una vez trabajado el fondo de cada discurso, han de trabajar la forma interna, esto es, la estructura del mismo y el tipo de lenguaje que se va a emplear para una alocución ante el público $y$ un jurado al cual persuadir. Por lo general, se suele educar en un lenguaje escrito, pero no oral. Con la presente fase se puede remediar esa carencia del currículo educativo.

\subsubsection{Practicar}

Redactado el discurso el debatiente ha de practicarlo y probarlo frente a sus compañeros de equipo en los que hacer debates de ensayo y error. Los ensayos han de ser la práctica de discursos entre ellos y de manera individual. Lo esencial de esta fase es que el estudiante controle los tiempos del discurso. De manera implícita, aprende el concepto de la gestión del tiempo al verse limitado por un tiempo que será cronometrado y observado por los jueces. La conjunción de ambas labores, de docente y estudiante, hará de un debate un ejercicio armonioso de práctica y de teoría en la que el alumnado aprende asumiendo un protagonismo compartido. En definitiva, se potencia el aprendizaje de manera cooperativa y no tanto la enseñanza. 


\subsubsection{Estructura (momentos de realización)}

La técnica del debate en el aula según Sánchez (2007) a grosso modo está conformada por los siguientes momentos:

- Antes (planificación y preparación).

- Durante (ejecución).

- Después (evaluación).

En síntesis, lo señalado por Sánchez (2007), ayuda a tener una idea muy clara acerca de los momentos de un debate:

El debate académico como se concibe en los Estados Unidos o Inglaterra se propone como herramienta de enseñanza y aprendizaje en el aula [...]. El modelo de debate propuesto gira en torno a una pregunta que el profesor comunica a los alumnos con tiempo suficiente para prepararlo.

$[\ldots]$.

Los alumnos divididos en grupos de cuatro o cinco como máximo defienden o atacan dicha pregunta según el uso de turnos de tiempo totalmente regulados durante unos 40 minutos. Durante el debate exponen sus argumentos principales a favor o en contra de la pregunta de debate (exposición inicial), después sus críticas (refutación y contrarrefutación) para terminar con las conclusiones. Al término, un jurado compuesto por profesor y alumnado (o sólo por el docente) declara ganador y pone la nota conforme a loscriterios del profesor. Mediante esta herramienta se consigue que el alumno desarrolle distintas competencias: cognitivas, de análisis, de expresión en público, argumentativas, etc. [...] El docente, puede enmarcar el debate según la naturaleza de sus objetivos: sensibilizadora, cognitiva, o procedimental. De esta manera se consigue que el alumno haga suyo el conocimiento 
de la asignatura (pues tiene que comunicarlo y defenderlo ante un público) y que el conocimiento del alumno sea significativo y no inerte (p. 1).

\subsubsection{Evaluación ${ }^{16}$}

Lo dicho en las anteriores líneas sobre el DEBATE, se incluye en la rejilla que se presenta en la TABLA NRO. 47. Su valoración desde lo cualitativo busca ofrecer la oportunidad de registrar observaciones y sugerencias de ajuste; desde lo cuantitativo, constituye un instrumento para brindar una calificación (nota) que dé cuenta de la calidad del trabajo que se revisa. Para determinar si se califica uno u otro valor, pueden consultarse las respectivas equivalencias en la TABLA NRO. 48.

TABLA NRO. 47. Rejilla para la valoración del debate.

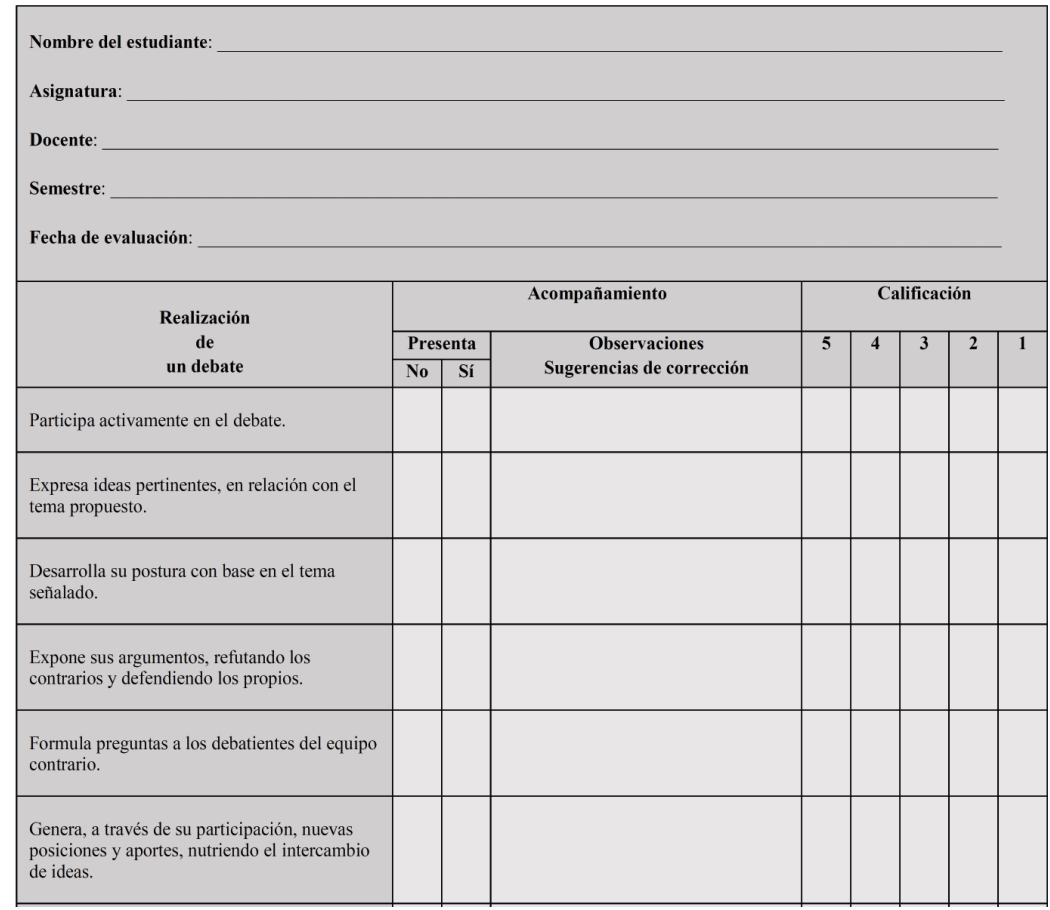

16 Apartado consolidado a partir de las referencias teóricas de Sánchez (2007), en su artículo «El debate académico en el aula como herramienta didáctica y evaluativa». ICADE. Universidad Pontificia de Madrid. Facultad de Ciencias Económica y Empresariales. 


\begin{tabular}{|l|l|l|l|l|l|l|l|}
\hline $\begin{array}{l}\text { Demuestra capacidad de escucha frente a } \\
\text { posiciones distintas a las suyas, y las asume } \\
\text { con respeto y comprension. }\end{array}$ & & & & & & & \\
\hline $\begin{array}{l}\text { Evidencia la capacidad de pensamiento } \\
\text { estratégico y empático frente a la postura de } \\
\text { sus compañeros. }\end{array}$ & & & & & & & \\
\hline $\begin{array}{l}\text { Llega a una conclusión, tras haber tenido en } \\
\text { cuenta lo acontecido durante el debate. }\end{array}$ & & & & & & & \\
\hline Valores parciales & & & & & & & \\
\hline Calificación obtenida & & & & & \\
\hline
\end{tabular}

Adaptada de Sánchez (2007).

TABLA NRO. 48. Equivalencias para la valoración del debate.

\begin{tabular}{|c|l|c|c|}
\hline Puntos & \multicolumn{1}{|c|}{$\begin{array}{c}\text { Equivalencias } \\
\text { en términos cualitativos }\end{array}$} & $\begin{array}{c}\text { Escala } \\
\text { puntos obtenidos }\end{array}$ & $\begin{array}{c}\text { Nota } \\
\text { obtenida }\end{array}$ \\
\hline 5 & Excelente: altamente adecuado. & 45 & 5.0 \\
\hline 4 & Bueno: adecuado (algunos errores u omisiones. & 36 & 4.0 \\
\hline 3 & Regular: inadecuado (muchos errores u omisiones). & 27 & 3.0 \\
\hline 2 & $\begin{array}{l}\text { Deficiente: no usa el recurso esperado o todos sus usos } \\
\text { son incorrectos. }\end{array}$ & 18 & 2.0 \\
\hline 1 & No sabe o no responde. & 9 & 1.0 \\
\hline
\end{tabular}

Elaboración propia. 


\section{Consideraciones finales}

Después de este panorama en el cual se muestra un amplio referente teórico, metodológico e ilustrativo de lo que significa la puesta en práctica de las competencias comunicativas en el ámbito de la educación superior, resta señalar algunas consideraciones que deben leerse como sugerencias intrínsecas al proceso pedagógico en relación con la lectura, la escritura y la oralidad.

1. Es claro de acuerdo con lo expuesto, que las competencias comunicativas básicas deben evidenciarse suficientemente en la actualización pedagógica del docente. Sin estas, ningún saber será comunicable desde el entendido que supone su organización en el discurso y sus prácticas personales de formación y aplicación pedagógica. En este sentido, todo maestro que quiera enseñar un saber, tendrá que ser consciente de que su ejercicio implica una constancia en los procesos de lectura, escritura y oralidad, cuyos sustratos obedecen a una dinámica de aprendizaje permanente. Esto significa que un docente es y será un aprendiz eterno.

2. La lectura, la escritura y la oralidad en tanto competencias intrínsecas en los maestros, deben procurarse hacia la cualificación progresiva. Esto supone que el ejercicio de la lectura, por una parte, debe ser logrado en una suerte de diálogo constante con los autores; esto es, una comunicación entre el docente activo, consciente de su lectura y reflexivo sobre las implicaciones que estas tienen en el global de los documentos y/o libros que se leen. Identificar voces referidas, mundos referidosyrelacionesintertextualesdediferente índole, hará que, efectivamente, el proceso de lectura en los docentes que osan enseñar, parta en mayor grado de la configuración cognoscitiva, del bagaje académico y cultural que aquellos tengan, y no tanto del texto en sí mismo; este modo de proceder que se logra con el 
conjunto de lecturas interiorizadas, constituiría la metodología que, reflexiva y operativamente, el profesor debe procurar con sus estudiantes en las dinámicas de lectura de cualquier tipo de género, texto y escrito, con los que tenga relación su saber específico.

Por otra parte, el ejercicio de la escritura en el docente debe ser una forma de mantenerse activo con lo que lee y con los pensamientos y posturas que genera a partir de las lecturas realizadas. Un docente que escribe, es un docente ejemplar para sus estudiantes en la medida en que se convierte en un referente pedagógico para la obtención de mejores resultados; además, la credibilidad y confianza que genera en su auditorio es algo irremplazable para el rapport o empatía académica. Pues la escritura, su publicación y su difusión, posibilitan naturalmente un reconocimiento de la otredad y su compromiso disciplinar, formativo y educativo. Así, la producción textual de los docentes puede convertirse en un espejo muy limpio para sus educandos quienes reconocerán en su tutor a un desempeño, cuando no un entrecruce coherente entre lo que dice, hace y piensa.

Finalmente, la oralidad como competencia no menor es la que prolíficamente los docentes deben llevar a cabo y pulir con el tiempo. Pues el discurso en la medida del avance, los estudios, las investigaciones y las clases mismas, deberá por derecho propio evidenciar una consolidación precisa y acorde con la lógica de la asignatura, la progresión de la ciencia en la que se inscribe y la elocuencia de los discursos orales. Tener claridad, proyección y coherencia en lo que se plantea, socializa y enseña en el aula de clase, supone proporcionarles confianza a los estudiantes. Un docente que se muestre tímido, con baja voz, inseguro, sin proyección, sin dominio temático, ni del auditorio, no genera en lo más mínimo seguridad para que sus estudiantes modelen su proceder. Por tanto, cultivar con decoro, pulcritud, disciplina y respetolas competencias comunicativas básicas, garantiza en los procesos de enseñanza y aprendizaje, la socialización adecuada de los saberes en función de hacer, saber, pensar, discutir, disentir, afirmar, criticar, reflexionar, entre otras actividades de 
orden superior, tareas propias de un docente comprometido no solo con el saber-saber per se, o con el contenido por el contenido, sino también, con el despunte, la provocación, el detonante; que solo la complicidad, la perspicacia y la pericia de aquel, hará explotar en múltiples dinámicas divergentes; no para algo diferente que no sean lecturas, escrituras y oralidades atinentes con la distinción y el avance del presente siglo XXI; de suyo hiper-tecnológico y disruptivo.

3. En correspondencia con lo expresado, los docentes tendrán que ser constantes animadores de los procesos de lectura, escritura y oralidad de sus estudiantes. Enseñar las distinciones entre los tipos de género, tipos de texto y tipos de escrito para educandos que inician su proceso de formación en el ámbito de la educación superior, es clave para encaminar pensamientos y acciones; sobre todo, de los futuros licenciados, quienes deben ser dirigidos hacia horizontes pedagógicos adecuados, altruistas y profundamente humanos en la relación de enseñanza y aprendizaje.

Solo con este proceder, se puede recuperar a través de la lectura, la escritura y la oralidad, dinámicas y valores tirados al traste por la irrupción de exigencias estandarizadas, universalismos y absolutismos implantados desde antaño en las prácticas educativas; las cuales, como cualquier docente reflexivo y crítico lo puede saber, solo han hecho que la educación se advierta como una mismidad que no varía. Este modo de verla, debe ser detonado por prácticas pedagógicas de docentes universitarios y futuros licenciados que adviertan que los procesos de educación se gestan desde la crítica, la proposición y la divergencia. No de otro modo, que a partir de lecturas, compromisos, diálogos y conversatorios en los que se propenda por recuperar lo más valioso de la educación: el reconocimiento del otro y su valía en los ámbitos históricos, académicos, sociales, políticos y culturales. 



\section{Referencias bibliográficas}

AdAM, J. (1992). Los textos: tipos y prototipos. Natha.

Agudelo, M. G.; Mesa, A. y Gómez, A. (2014). Pensamiento $y$ palabra. Pensar, argumentar, hablar, leer y escribir. Universidad Tecnológica de Pereira.

Agudelo, M. G.; Gallego Cortés, G. N. y Toro Raga, C. I. (2010). La lectura y la escritura en la universidad: la transición de lo ideal a lo real. Universidad Tecnológica de Pereira.

Álvarez, G. T. (2005). Didáctica del texto en la formación del profesorado. Editorial Síntesis S. A.

Álvarez, González, C.J. (2010). La relación entre lenguaje y pensamiento de Vigotsky en el desarrollo de la psicolingüística moderna. RLA. Revista de lingüística teórica y aplicada, 48(2), 13-32.

Álvarez, T. (2010). Competencias básicas en escritura. Ediciones Octaedro.

Arguelles, D. (2014). Escribir y leer con los niños, los adolescentes $y$ los jóvenes. Océano.

Bajtín, M. (1929). El marxismo y la filosofía del lenguaje. Alianza Editorial.

(1979). El problema de los géneros discursivos. (Extractos). En G. Morson. (Comp.). Bajtín: Ensayos y diálogos sobre su obra (pp. 161-172). Fondo de Cultura Económica.

. (1984). Estética de la creación verbal (7. ${ }^{\text {a }}$ ed.). Siglo XXI Editores. 
Benveniste, E. (1977). Problemas de lingüística general II. Siglo XXI Editores.

Berger, Peter P. I. y Luckmann. T. (2001). La construcción social de la realidad. Amorrortu Editores.

Bernal León Gómez, J. (1984). Tres momentos estelares en Lingüística. Publicaciones del Instituto Caro y Cuervo.

Bogoya Maldonado, D. (2000). Competencias y proyecto pedagógico. Universidad Nacional de Colombia.

Bourdieu, P. (2008). El sentido práctico. Siglo XXI Editores.

Carlino, P. (2005). Escribir, leer y aprender en la universidad. Una introducción a la alfabetización académica. Fondo de Cultura Económica.

- (2007). ¿Qué nos dicen hoy las investigaciones internacionales sobre la escritura en la universidad? [Conferencia]. I Encuentro Nacional de Discusión sobre Políticas Institucionales para el Desarrollo de la Lectura y la Escritura en la Educación Superior.

Cassany, D. (1993/1995). La cocina de la Escritura. Anagrama.

- (2004). Explorando las necesidades actuales de comprensión aproximaciones a la comprensión crítica. Lectura y vida, XXV(2), 6-23. Universitat Pompeu Fabra.

. (2006). Tras las líneas. Sobre lectura contemporánea. Anagrama.

. (2012). En-línea. Leer y escribir en la red. Anagrama.

Cassany, D.; Luna, M. y SAnZ, G. (1994/2007). Enseñar lengua. Editorial GRAO. 
Charaudeau, P. (2004). La problemática de los géneros. De la situación a la construcción textual. Revista Signos, 37(56), 23-39.

Ciapuscio, G. E. (1994). Tipos textuales. Ciclo Básico Común.

Cisneros, M. (2014). Lectura y escritura en la universidad: una investigación diagnóstica. Universidad Tecnológica de Pereira.

Cohen, L. Y Manión, L. (1990). Métodos de investigación educativa. Editorial La Muralla S.A.

Coll, C. (2004). Lenguaje, actividad y discurso en el aula. En: Desarrollo psicológico y educación. Psicología de la educación escolar (pp.387-414). Alianza Editorial.

Consejo superior de la Universidad Tecnológica DE Pereira. (2014, 22 de diciembre). Acuerdo No. 41. https:// www.utp.edu.co/cmsutp/data/bin/UTP/web/uploads/ media/comunicaciones/documentos/Acuerdo-41.pdf.

Conto, López, M.R. (2015). La ponencia. Documentos de la Universidad Agraria de Colombia. https://www.uniagraria. edu.co/images/eventos/2015/Julio/LA\%20PONENCIA. pdf.

Culioli, Á. (1976). La formalización en lingüística. Lenguajes, 3, 11-25. Santiago Arcos.

Dagua, C. M.; Calderón, M. C.A. y Estupiñán, M. C. (2011). Estrategias de interacción oral en el aula: una didáctica crítica del discurso educativo. Cooperativa Editorial Magisterio

De Saussure, F. (1945). Curso de Lingüística General. (Traducción, prólogo y notas de Amado Alonso). 24. ${ }^{\mathrm{a}}$ edición. Editorial Losada. 
Decel. (2020). Diccionario Etimológico. http://etimologias. dechile.net/.

DíAz, Á. (2002). La argumentación escrita. Editorial Universidad de Antioquia.

. (2014). Retórica de la escritura académica. Pensamiento crítico y argumentación discursiva. Editorial Universidad de Antioquia.

Ducrot, O. (1985). Le dire et le dit. Minuit.

. (1988). Polifonía y argumentación. [conferencias del seminario Teoría de la Argumentación y Análisis del Discurso]. Universidad del Valle.

Escandell Vidal, M. V. (1996). Introducción a la pragmática. Ariel

Giraldo y Osorio. (2017). Representaciones discursivas del habla juvenil en la educación Media. Fundamentos, análisis y prácticas. Editorial Redipe. Investigación educativa y pedagógica iberoamericana.

González, E. A.; Vila, T. D., y De Carlos, P. (2016). Evaluación de la utilización de los debates académicos como metodología docente. El debate en el aula, 95.

Halliday, M. A. K. (1979/1998). El lenguaje como semiótica social. La interpretación social del lenguaje y del significado. Fondo de Cultura Económica.

Herrera, D.; Cisneros, M. y Muñoz, C. (2014). Perspectivas y prospectiva en los estudios sobre Lectura y Escritura. Universidad Tecnológica de Pereira. 
ICONTEC. (2008). NTC 1486. Sexta Actualización julio 23 de 2008. Presentación de tesis, trabajos de grado y otros trabajos de investigación. Instituto Colombiano de normas Técnicas y Certificación.

Jаковson, R. (1984). Ensayos de Lingüística general. Ariel.

Jaramillo, C. (s. f.). La exposición oral. Universidad Santo Tomás. Primer claustro universitario de Colombia. Educación abierta y a distancia.

Jiménez Ríos, E. (2019). Participio pasivo y arcaísmo en el DRAE (ediciones de 1822 y 1832). ELUA: Estudios de Lingüística, Extra 5, 233-251. https://rua.ua.es/dspace/ bitstream/10045/100827/1/ELUA-Anexo-V_10.pdf.

Kerbrat, O. C. (1980). La enunciación. De la subjetividad en el lenguaje. Hchette.

LAKoff, G. Y Johnson, M. (1980). Metáforas de la vida cotidiana. Cátedra.

LOpera Lopera, L. H. (s.f.). El informe de lectura. En Seminario de Ética Bibliotecológica. Universidad de Antioquia. Recuperado el 5 de marzo de 2019 en: <http://caribe.udea. edu.co/ hlopera/Web-etica/Informe_de_lectura.html $>$.

Maingueneau, D. (1996). El ethos y la voz de lo escrito. Revista Cultura y Discurso. 6, 79-92.

https://versionojs.xoc.uam.mx/index.php/version/article/ download $/ 87 / 87$.

Martínez, M. C. (2002). Estrategias de lectura y escritura de textos. Perspectivas teóricas y talleres. Cátedra UNESCO MECEAL. Universidad del Valle. 
. (2005). La construcción del proceso argumentativo en el discurso. Perspectivas teóricas y trabajos prácticos. Cátedra UNESCO MECEAL. Universidad del Valle.

Maya B., A. Y DíAz G., N. (2012). Mapas conceptuales: elaboración y aplicación. Editorial Magisterio.

Martínez-Muñoz, C.; Andrade, M. y Cisneros-Estupiñán, M. (2011). Estrategias de interacción oral en el aula: una didáctica crítica del discurso educativo. Editorial Magisterio.

Ministerio de Educación Nacional. (1998). Lineamientos curriculares. Lengua castellana. Cooperativa editorial magisterio.

Niño Rojas, V. M. (1994). Los procesos de la comunicación y del lenguaje. Fundamentación y práctica. Ecoe Ediciones.

Ong, W. (1982). Oralidad y escritura. Tecnologías de la palabra. Fondo de Cultura Económica.

Ortega García, O.; Rodríguez Calle, J. y Montaño, M. (2016). Aspectos generales de un modelo de oralidad en la Universidad ICESI. Revista CS, 18, pp. 183-210. doi: 10.18046/recs.i18.2057.

Peña Borrero, L. B. (2008). La competencia oral y escrita en la educación superior. Publicación electrónica. [consultado 20 de marzo de 2020] http://www.saber.ula.ve/ bitstream/handle/123456789/31155/la_competencia_ oral_escrita. pdf;jsessionid=F8B18253185EEFECFC90 6DDD4A9FEE44? sequence $=2$

(2010) Aprender a leer y escribir en la universidad. Publicación electrónica. [consultado 20 de marzo de 2020] https://www.academia.edu/34908439/ Pen_a_L_B_2012_Aprender_a_leer_y_escribir_en_la_ universidad_pdf. 
Pérez Abril, M. (2000). Hacia una pedagogía del discurso: Elementos para pensar la competencia argumentativa en los procesos de la escritura en la educación básica. D. Bogoya Maldonado, M. Vinent Solsona, G. Restrepo Forero, M. C. Torrado Pacheco, F. Jurado Valencia, M. Pérez Abril, M. Acevedo Caicedo, G. García Oliveros, F. Sarmiento Parra, F. Cardenas Salgado, J. Granés Sellares, L. G. Díaz Monroy. Competencias y proyecto pedagógico (pp. 107-138). UNIBIBLOS. Universidad Nacional de Colombia.

Pérez Abril, M. y Rincón, G. (Coords.). (2013). ¿Para qué se lee y escribe en la universidad colombiana? Editorial Pontificia Universidad Javeriana.

Ramírez, Peña. L. A. (2007). Comunicación y discurso. La perspectiva polifónica en los discursos literario, cotidiano $y$ científico. Magisterio.

Real Academia Española. (2010). Ortografía de la lengua española. Asociación de academias de la lengua española.

. (2019). Diccionario de la lengua española. $23^{\circ} \mathrm{ed}$., [versión 23.3 en línea]. <https://dle.rae.es $>$ [consultado 20 de marzo de 2020].

Resolución NRO. 02041 (2016, 3 de febrero). Ministerio de Educación Nacional. https://www.mineducacion.gov. co/1759/articles-356144_recurso_1.pdf.

Resolución NRO. 18583. (2017, 15 de septiembre). Ministerio de Educación Nacional. Diario oficial No 50357. https:// www.icbf.gov.co/cargues/aance/docs/resolucion_ mineducacion_18583_2017.htm.

Resolución del Consejo Académico Nº 220 (2018, 08 de enero). Universidad Tecnológica de Pereira. 
Rojas Ortiz. J. (1996). El ensayo. Historia y Teoría. Fondo Editorial Cooperativo.

Sánchez Prieto, G. (2007). El debate académico en el aula como herramienta didáctica y evaluativa. ICADE. Universidad Pontificia de Madrid.

Sánchez S.; Bautista, A.; Muñoz, K y Pellegrino, V. (2017). Guía para la elaboración de una Ponencia. Universidad de los Andes. http://leo.uniandes.edu.co/index.php/oralidadsec-menu/53-guia-para-la-elaboracion-de-una-ponencia.

Schmidt, S. (1978). Teoría del texto. Problemas de una lingüística de la comunicación verbal. Cátedra.

Serna, A, J. (2011). Las apuestas perdidas de Occidente. Universales, inmortalidad y culto al presente. Editorial Anthropos.

VAN Dijk, T. (1989). Estructura y funciones del discurso. Siglo XXI Editores.

VÁsquez Rodríguez, F. (2004). Pregúntele al ensayista. Editorial Kimpres (2016). Las claves del ensayo. Editorial Kimpres. 
Este libro contiene información útil para los docentes que hayan decidido apoyar a sus estudiantes, en sus procesos y productos lectores, escritores y de oralidad. Surge como insumo para la implementación de la Estrategia de acompañamiento a los estudiantes de licenciatura de la Facultad de Ciencias de la Educación de la Universidad Tecnológica de Pereira, en materia de competencias comunicativas, atendiendo una necesidad sentida en el cuerpo profesoral: tener a disposición herramientas que les permita retroalimentar a los estudiantes cuando de su comprensión de lectura, producción de textos y realización de intervenciones orales, se trate.

Encontrará aquí, estimado lector, un compendio de documentos de apoyo, donde se integra lo conceptual, procedimental, estructural y evaluativo concerniente a los productos de cada competencia, comúnmente usados en los procesos de enseñanza y aprendizaje desde cualquier área del conocimiento.

Es así como, para la comprensión de lectura (textos digitales o impresos, eventos, películas, situaciones y del entorno en general), tenemos a su disposición: análisis, resumen, síntesis, informe de lectura, lectura comentada, reseña crítica y algunos organizadores gráficos. Para la producción de textos escritos: Trabajo escrito, ensayo argumentativo y ponencia. Y para la realización de intervenciones orales: Exposición, mesa redonda y debate.

Esperamos que estos insumos le sean de gran utilidad, tanto para su labor docente, como para su propia cosecha en actividades de orden superior, como lo son la lectura, la escritura y la oralidad. 